UNIVERSIDADE DE SÃO PAULO

FACULDADE DE FILOSOFIA, LETRAS E CIÊNCIAS HUMANAS

DEPARTAMENTO DE LETRAS ORIENTAIS

PROGRAMA DE LITERATURA E CULTURA RUSSA

BIANCA ALVES DA PAIXÃO

\title{
A LITERATURA INFANTIL DE DANIIL KHARMS: TRADIÇÃO E MODERNIDADE
}


FACULDADE DE FILOSOFIA, LETRAS E CIÊNCIAS HUMANAS

DEPARTAMENTO DE LETRAS ORIENTAIS

PROGRAMA DE LITERATURA E CULTURA RUSSA

\section{A LITERATURA INFANTIL DE DANIIL KHARMS: TRADIÇÃO E MODERNIDADE}

Dissertação apresentada ao Programa de Pós-Graduação em Literatura e Cultura Russa do Departamento de Letras Orientais da Faculdade de Filosofia, Letras e Ciências Humanas da Universidade de São Paulo como requisito para obtenção do título de Mestre em Literatura e Cultura Russa.

Orientador: Prof. Dr. Homero Freitas de Andrade 


\section{A LITERATURA INFANTIL DE DANIIL KHARMS: TRADIÇÃO E MODERNIDADE}

Dissertação de mestrado apresentada ao Programa de Pós-Graduação em Literatura e Cultura Russa do Departamento de Letras Orientais da Faculdade de Filosofia, Letras e Ciências Humanas da Universidade de São Paulo, aprovada pela Banca Examinadora constituída pelos seguintes professores:

Prof. Dr. Homero Freitas de Andrade

Faculdade de Filosofia, Letras e Ciências Humanas

Universidade de São Paulo

Orientador

Prof. Dr. João Azenha Jr.

Faculdade de Filosofia, Letras e Ciências Humanas

Universidade de São Paulo

Profa. Dra. Sheila Oliveira Lima

Centro de Letras e Ciências Humanas Universidade

Estadual de Londrina

São Paulo

2015 


\section{AGRADECIMENTOS}

Agradeço imensamente ao meu orientador prof. Dr. Homero Freitas de Andrade, por acreditar no meu trabalho, pela orientação atenta e generosa.

Em segundo lugar, agradeço ao meu esposo, Marcelo Bernardes Garcia, pelo amor mais sincero e devotado que já conheci. Sem seu apoio incondicional, nada disso seria possível.

Aos meus queridos pais, Raimunda Alves da Paixão e Adaldiso Ribeiro da Paixão, que na simplicidade de nossa casa, em meio às nebulosas conversas de infância, mostraram-me no mapa-múndi uma tal de URSS, “o maior país do mundo"... e acabaram lançando a primeira semente de interesse por essa rica literatura.

Às minhas amadas irmãs, Grace Alves da Paixão e Nathalie Alves da Paixão, com quem viveria outras sete vidas, se preciso fosse. E minha sobrinha, Laura da Paixão Augusto, que ilumina meus dias.

Aos meus cunhados, Ivan Mamede e Ricardo Augusto, por encherem de alegria nosso convívio familiar.

Gostaria de agradecer à preciosa ajuda da amiga Flávia Cristina Aparecida Silva, pelas leituras cuidadosas que fez de meu trabalho e pelas agradáveis conversas sobre a vida.

Agradeço também à Júlia Godoy, por sua amizade e pelas mensagens sempre bem-humoradas; à diretora Danila Orbea Maggi e toda equipe da EMEI Roberto Burle Marx (ano de 2012); às queridas Renata Galvão, Márcia Junger e Lucinda Vieira, da EMEI Pero Neto (ano de 2014), por tornarem meu cotidiano mais ameno e sempre alegre.

Rosângela Caproni, Daniela Ferla e Cláudia Medeiros, obrigada pelo incentivo e boas vibrações. Rosana Mendonça, Patrícia Martins Penna e Ana Paula Montanari, amigas de uma vida, sei que também estão sempre na torcida.

Por fim, não posso deixar de agradecer à Ekaterina Vôlkova Américo pelo cotejo dos contos. 
PAIXÃO, Bianca Alves. A literatura infantil de Daniil Kharms: tradição e modernidade. São Paulo, 2015. 281f. Dissertação (Mestrado em Literatura e Cultura Russa) - Faculdade de Filosofia, Letras e Ciências Humanas, Universidade de São Paulo.

\section{RESUMO}

Esta dissertação busca analisar os aspectos da tradição e da modernidade literária presentes na prosa infantil do escritor soviético Daniil Kharms (1905 - 1942), tendo em vista o diálogo que estabelecem com os contos maravilhosos e a observância dos processos de atualização do gênero, decorrente das políticas educacionais, na URSS. Os trabalhos do escritor dedicados à criança foram os únicos publicados em vida, num contexto de forte censura. Desse modo, tal obra ganha importância tanto para a compreensão dos pressupostos estéticos de Kharms, quanto para a percepção das transformações ocorridas na literatura infantil soviética a partir da imposição do realismo como método de representação. Para tanto, selecionamos um corpus de trinta e um contos, traduzidos diretamente do russo.

Palavras-chave: Daniil Kharms, Literatura Infantil, Literatura Soviética, Tradição; Modernidade. 
PAIXÃO, Bianca Alves. Children's literature of Daniil Kharms: tradition and modernity. São Paulo, 2015. 281f. Dissertação (Mestrado em Literatura e Cultura Russa) - Faculdade de Filosofia, Letras e Ciências Humanas, Universidade de São Paulo.

\begin{abstract}
This dissertation aims to analyze aspects of tradition and modern literature presented in the children's prose of the Soviet writer Daniil Kharms $(1905-1942)$, in view of the dialogue that it establishes with fairy tales and the observance of gender upgrade, resulting from education policies in USSR. The writer's work dedicated to children were the ones he could publishes in life, due to a background of strong censorship. Thus, this work becomes important both for understanding Khams's aesthetic assumptions and for the perception of the transformations occurred in Soviet children's literature, after the imposition of realism as the only possible representation method. To compose our corpus, we selected thirty-one stories directly translated from Russian.
\end{abstract}

Key-words: Daniil Kharms; Children's Literature; Soviet Literature; Tradition; Modernity. 


\section{Sumário}

APRESENTAÇÃO 9

1. APONTAMENTOS SOBRE AS TRADUÇÕES 13

$\begin{array}{ll}1.2 \text { CONTOS INFANTIS DE DANIIL KHARMS } & 22\end{array}$

— VOCÊ ESTEVE NO JARDIM ZOOLÓGICO? $\quad 22$

$\begin{array}{ll}\text { O FUSÍVEL TRAVESSO } & 24\end{array}$

$\begin{array}{ll}\text { EM PRIMEIRO E EM SEGUNDO LUGAR } & 31\end{array}$

OS DEZESSETE CAVALOS $\quad 36$

COMO KolKa PÁNKIN VOOU PARA O BRASIl E PIETKA ERCHOV NÃO ACREDITOU EM NADA. 38

A PENA DA ÁGUIA DOURADA $\quad 52$

COMO UMA VELHINHA COMPRAVA TINTA $\quad 61$

CERTA VEZ, o LEÃO, O ELEFANTE, A GIRAFA, A RENA, O AVESTRUZ, O ALCE 70

A LEBRE E O OURIÇO 73

UMA VEZ, COMPREI UM LÁPIS, FUI PARA CASA E SENTEI PARA DESENHAR 77

— OLHA, LIÉNOTCHKA, — DISSE A TIA — VOU SAIR $\quad 79$

OS DOIS AMIGOS, KÓLIA KÓKIN E VÂNIA MÓKHIN

VOLÓDIA ESTAVA NA FESTA DE ANO NOVO $\quad 82$

"UM ATRÁS DO OUTRO" 83

ERA VERÃO. O SOL BRILHAVA. FAZIA MUITO CALOR 90

UMA VEZ PERGUNTARAM-ME COMO FUNCIONA O AUTOMÓVEL. 93

EM CADA ESCOLA DOS ESTADOS UNIDOS HÁ UM CARTAZ PENDURADO: 98

O PROFESSOR TRÚBOTCHKIN $\quad 99$

KOLPAKOV, O FANFARRÃO $\quad 111$

COMO MACHA FEZ O BURRO LEVÁ-LA PARA A CIDADE 113

$\begin{array}{ll}\text { O OURIÇO VALENTE } & 114\end{array}$

$\begin{array}{ll}\text { O QUEBRA-OSSOS } & 115\end{array}$

$\begin{array}{ll}\text { UM CONTO MARAVILHOSO } & 122\end{array}$

NO ANO PASSADO FUI COMEMORAR O ANO NOVO NA CASA DE MEUS AMIGOS E AMIGAS 126

$\begin{array}{ll}\text { SOBRE O CACHORRO BUBUBU } & 127\end{array}$

$\begin{array}{lr}\text { OS SETE GATOS } & 129\end{array}$

VOLÓdIA ESTAVA SENTADO À MESA DESENHANDO. 131

UM ACONTECIMENTO MISTERIOSO 134

CERTA VEZ, PÉtia PREgOV $\quad 135$

$\begin{array}{ll}\text { PÚCHKIN } & 136\end{array}$

$\begin{array}{ll}\text { A RAPOSA E A LEBRE } & 141\end{array}$

2. DO OBERIU AO BRASIL 143

2.1 O REALISMO SOCIALISTA: A ESTÉTICA DO NOVO REGIME. 143

2.2 DANIIL KHARMS: VIDA E VANGUARDA. 152

2.3 A OBRA KHARMISIANA: TRAJETÓRIA DAS PUBLICAÇÕES. 167

3. AS RAÍZES DA LITERATURA INFANTIL E AS DIRETRIZES SOVIÉTICAS PARA O GÊNERO 180

3.1 A GÊNESE DA LiTERATURA INFANTOJUVENIL (LIJ) 180

3.2 A LITERATURA INFANTOJUVENIL SOVIÉTICA: A BUSCA PELO NOVO. 186

3.3 O PROBLEMA DO MARAVILHOSO 193

4. A LITERATURA INFANTIL DE DANIIL KHARMS: TRADIÇÃO E MODERNIDADE. 199

4.1 TRADIÇÃO E MODERNIDADE 199

4.2 MARCAS DO COTIDIANO E DA MODERNIZAÇÃO SOCIAL NA LITERATURA INFANTIL KHARMISIANA 202

4.3 APROXIMAÇÃO ENTRE OBRA E LEITOR 220

4.4 DA TRADIÇÃO À EXIGÊNCIA SOVIÉTICA: A CRIANÇA COMO PERSONAGEM. 223 
4.5 PERSONAGENS CARICATURAIS

4. 6 PARÓDIA E ATUALIZAÇÃO DO GÊNERO.

4.6 O FANTÁSTICO-MARAVILHOSO

4.7 VIOLÊNCIA

4.8 A LINGUAGEM TRANSMENTAL (ZAUM)

4. 9 SUPREMATISMO

4. 10 INCIDENTES

CONSIDERAÇÕES FINAIS

272

REFERÊNCIAS BIBLIOGRÁFICAS: 



\section{APRESENTAÇÃO}

Eu não gosto de crianças, velhos, velhas e da prudência dos indivíduos experientes.

Daniil Kharms

Daniil Kharms (1905 - 1942) foi um conhecido escritor de poesias e contos para crianças, entre os anos 1920 a 1930, cuja carreira na literatura infantil começou depois que sua obra "para adultos" passou a ser proibida, na União Soviética stalinista. Devido às circunstâncias políticas, seus trabalhos ligados à literatura do absurdo e à arte experimental foram cabalmente proibidos pelo teor contrarrevolucionário. De modo que, o autor acabou impossibilitado de publicar.

Para dar continuidade ao trabalho, Kharms empregou-se como escritor, passando a compor obras infantis para duas revistas que circulavam, à época, em Leningrado: Ioj e Tchij. Esta foi, então, a única parcela de sua obra que conseguiu publicar em vida.

Desse modo, a literatura infantil garantia ao escritor um salário e a única possibilidade de dedicar-se oficialmente à literatura, na URSS. Curiosamente, Kharms parecia não nutrir muito apreço pelo seu público leitor, como revelam a epígrafe e o seguinte trecho da novela "A velha":

Da rua chega uma gritaria insuportável da meninada. Fico deitado, maquinando um suplício para eles. Mais que tudo, gostaria de lançar contra eles um tétano para que parassem imediatamente de se movimentar. Os pais os arrastam para casa. Os meninos ficam deitados nas suas camas e não conseguem sequer comer, porque a boca não abre. São alimentados artificialmente. Em uma semana o tétano passa, mas as crianças estão tão fracas que ainda devem ficar de cama por mais um mês inteiro. Daí elas começam a se estabelecer pouco a pouco, mas eu lanço um outro tétano contra elas, e todas morrem. (In: LIMA, S. O., 2001, p. 20)

Contudo, a despeito do humor negro com que tratava essa "meninada", a literatura infantil kharmisiana era bastante apreciada, suas poesias eram conhecidas das crianças e as personagens de Ioj e Tchij faziam parte da infância dos pequenos cidadãos soviéticos, 
nas primeiras décadas do regime soviético. Essa identificação com o leitor, tornava-se possível através do diálogo da obra com o naif, o maravilhoso e o nonsense, entre outros elementos caros ao gênero.

Naquele momento, a literatura fazia parte do grande projeto educativo soviético, assim, todo o cuidado era pouco, no que diz respeito à adequação política das obras, pois a crítica partidária estava sempre à caça de inimigos do povo e não hesitava em jogar escritores no ostracismo. Na condição de escritor de vanguarda, Kharms resistiu o quanto pôde aos ditames da censura, porém, após sua morte, em 1942, sua obra infantil também foi esquecida da memória soviética, vindo a ser totalmente recuperada cinquenta anos mais tarde.

Observamos três esferas atuarem simultaneamente no fornecimento de bases para as narrativas de Kharms: o arcabouço da literatura infantil, o contexto sócio-político e a vanguarda. Tendo em vista que, tal obra foi composta numa fase de transição em que a literatura cada vez mais extrapolava os limites do fazer artístico para ocupar lugar enquanto método educativo do Estado.

O presente trabalho apresenta a tentativa de análise da prosa infantil kharmisiana sob a perspectiva da tradição e da modernidade presentes nos elementos narrativos dos contos. O foco de nossa abordagem é, justamente, verificar o modo como essa mescla entre os elementos da tradição, os traços estéticos e fatores de ordem social colaboram para a criação de uma literatura infantil experimental.

Buscamos apoio teórico para nossa interpretação nos trabalhos de Vladimir Propp, Regina Zilberman, Nelly Novaes Coelho e Orlando Figes.

A primeira parte apresenta uma nota geral às traduções que foram feitas a partir dos textos originais em russo. Para compor nosso corpus de pesquisa selecionamos 
integralmente todos os contos disponíveis nas obras completas do escritor, citadas na bibliografia. Assim, chegamos ao total de trinta e uma histórias escritas por Daniil Kharms, entre 1928 e 1940.

A segunda parte está dividida em três capítulos: o primeiro, "Do OBERIU ao Brasil", aborda as principais mudanças ocorridas no cenário artístico durante as primeiras décadas do regime soviético, além de fornecer um panorama geral sobre o Realismo Socialista. A seguir, retratamos tanto a trajetória de vida de Kharms, quanto as principais propostas estéticas do grupo experimental OBERIU. Por fim, arrolamos a sequência de publicações do autor, desde o começo de sua carreira, passando pelo período de abertura da URSS, até as primeiras traduções em português.

No capítulo "As raízes da literatura infantil e as diretrizes soviéticas para o gênero", apresentamos as bases histórico-culturais que contribuíram para o surgimento do gênero, enfatizando o papel fundamental exercido pelos contos populares e maravilhosos nesse processo. Em seguida, analisamos as principais implicações para a produção literária infantil soviética num contexto em que o fantástico-maravilhoso passa a dar lugar ao realismo.

No terceiro e último capítulo “A literatura infantil de Daniil Kharms: tradição e modernidade", apresentamos a análise dos elementos narrativos dos contos, expondo seu diálogo com a tradição dos contos maravilhosos e os principais procedimentos de atualização do gênero empregados pelo escritor com vistas à produção de uma obra moderna, embasada nas demandas político-sociais da criança soviética. 


\section{PARTE I}




\section{Apontamentos sobre as traduções}

A presente nota tem como objetivo fornecer ao leitor informações gerais a respeito do trabalho aqui realizado, no sentido de esclarecer os critérios empregados no processo de tradução. Para tanto, traçaremos um panorama geral abordando o trabalho realizado, no conjunto dos textos.

As trinta e uma histórias que compõem o corpus desta dissertação foram escritas para serem lidas, a princípio, tanto por Pioneiros - com idade entre dez e quatorze anos quanto por crianças menores, ou seja, estudantes que já tivessem ultrapassado a fase inicial de aprendizado da leitura. São textos que revelam características e procedimentos da obra kharmisiana, além de apresentarem uma visão geral dos primórdios da literatura infantil soviética.

Utilizamos como fonte os textos originais em russo presentes em três coletâneas de obras do escritor (citadas na bibliografia deste trabalho). A saber: A antologia de 2009, editada em um único volume, contém uma seleção de textos variados (poemas, histórias para crianças, cartas e textos teóricos). Tal edição possui um capítulo de histórias e poemas infantis.

A coletânea de 1994 conta com dois volumes e um deles é destinado à produção infantil, possui ilustrações que acompanham os poemas e histórias. A obra mais recente, de 2011, está dividida em três volumes, sendo que o último, denominado Тигр на улиие (Um tigre na rua), é dedicado aos poemas e histórias para crianças, além de contar com um prefácio do organizador Valiéri Sájin. Apenas esta última edição apresenta notas a respeito da origem dos textos nela contidos que foi utilizada em nosso trabalho como fonte de pesquisa. 
Em nosso trabalho, optamos por ampliar o rol de receptores dessa coletânea, pois acreditamos que, no contexto atual, as narrativas aqui apresentadas podem abrir possibilidades de interpretação da obra de Kharms e lançar luz a aspectos da estética OBERIU. Por outro lado, para que as traduções pudessem tornar-se acessíveis às crianças brasileiras contemporâneas, caso fosse nossa intenção, a transposição entre os textos fonte e alvo careceriam de inúmeras adaptações e intervenções de reescrita; exercício que dispensaria, em muito, os elementos específicos da cultura soviética que permeiam as narrativas e são caros à nossa análise.

Tendo como objetivo a análise dos elementos de tradição e modernidade dentro da literatura infantojuvenil kharmisiana e por tratar-se de nossa primeira experiência em tradução, focalizamos como público alvo, não apenas crianças, mas estudiosos e interessados em literatura russa, em geral. Essa opção ajudou-nos a definir nossa principal estratégia de tradução: a manutenção das feições gerais do texto original através da conservação dos principais elementos de experimentação artística e da cultura russosoviética empregados pelo escritor.

Uma vez definido nosso público e estratégia, procedemos às traduções, tarefa que se realizou em três etapas principais: 1-) elaboração da tradução inicial com objetivo de ter acesso à obra como um todo, com atenção especial ao léxico e estilo do escritor; 2-) cotejo com falante nativo da língua russa, com o propósito de excluir possíveis erros de tradução ou interpretações errôneas, além dirimir dúvidas quanto aos elementos de oralidade presente em algumas narrativas; 3-) elaboração do texto final a partir da eleição de critérios gerais de tradução, em paralelo com o trabalho de pesquisa sobre a literatura de Kharms. Nessa etapa, adequações sintáticas foram feitas para garantir a fluência de leitura nas traduções. Sobre esse processo, seguem algumas considerações: 
Uma de nossas escolhas, ao longo dessas etapas, diz respeito à manutenção dos traços de estrangeirização no texto fonte, sempre que possível. Por isso, conservamos os topônimos que dão caracterização soviética ao texto: Leningrado, rua Mokhováia etc; o mesmo para as siglas e alusões às instituições daquela sociedade: Casa da Criança, Pioneiros, Vesenkha. Há, do mesmo modo, nas traduções, objetos e expressões típicos das culturas russa e soviética: samovar, Primus, camarada, entre outros. Sabemos que, para o leitor brasileiro, essas denominações podem causar estranheza dadas as diferenças socioculturais que distanciam os textos de partida e chegada; portanto, sempre que julgamos necessário, inserimos uma nota, de rodapé ou de fim, complementar e explicativa visando ajudar na compreensão ou inserir informações importantes subliminares ao texto.

O estilo literário de Kharms dispensa o rebuscamento, sua linguagem é acessível e coloquial, característica que garantia maior adesão do público infantil. Entretanto, ao longo do trabalho verificamos o uso de palavras não comuns ao repertório das crianças, mas por acreditarmos que uma das funções educativas da literatura infantil diz respeito à apresentação do novo aos pequenos e tendo em vista que nosso universo de leitores foi aqui ampliado, decidimos pela manutenção do léxico original. Por isso, a presença de palavras e expressões como: chilreia, flanco, pó dentifrício, tinteiro, a vau, linotipista etc.

Muitas vezes os nomes imaginados por Kharms para as personagens são sonoros e falam por si, pois derivam de verbos ou substantivos inusitados que vem à mente do falante/leitor nativo automaticamente quando este ouve ou lê as histórias. Por exemplo, Arbuzóv que, o leitor russo, associa diretamente a "arbúz” (арбуз), ou seja, melancia; ou Apielsínov, genitivo plural de "apielsín” (апельсин) que significa laranja. Entre tantas outras ocorrências do mesmo tipo ao longo das narrativas. Assim, deparamo-nos 
com o seguinte dilema: traduzir e adaptar esses nomes significativos para o português ou não? Até que ponto valeria a pena chamar essas personagens de "Melancíades" ou "Laranjada"; quem sabe conferir-lhes um acabamento russificado como "Melanciov" ou "Laranjéiev"? Percebemos que a adaptação garantiria os traços de humor e brincadeira característicos da literatura infantil, porém haveria prejuízo dos elementos russos do texto. Então, optamos por manter os nomes empregados pelo escritor em seu original russo e traduzi-los apenas quando a denominação da personagem estivesse diretamente ligada às suas ações na narrativa. É o que ocorre, por exemplo, com Altofalante, literalmente em russo "Gromkovoditel” (громкоговоритель), que assim era chamado porque "sempre falava a plenos pulmões e não conseguia conversar em voz baixa" (p. 25); e com Pétia Pregov - no original Pétia Gvózdinikov, cujo sobrenome refere-se ao verbo "gvózdit" (гвоздить) e significa pregar, martelar. Garotinho para quem "de certo seria interessante pregar o gato na porta pela orelha" (p. 135). Em todos os casos, há notas explicativas que indicam as alusões existentes na língua russa às quais o leitor brasileiro percebe.

Quanto as brincadeiras linguísticas existentes nas histórias, utilizamos a seguinte estratégia: para as onomatopeias de sons de animais, meios de transporte, entre outras; buscamos utilizar o correspondente onomatopaico em português. Por exemplo, em russo, o coaxar do sapo é expresso como " $k v a$ " ( $\kappa в a)$; o grasnar do pato por "criá" (кpя); o chiado do bonde é “djém” (джен), os quais traduzimos respectivamente como "croac", “quá" e “dlen". Visto que essas são as representações mimológicas desses sons em nossa língua. Vejamos: “O professor ralha e a rã: Croac, croac!” (p. 68); “Chegou a patinha Aninha. Olhou para o quadro de um lado e disse: — Quá, quá, quá!” (p. 127); “ Dlen, dlen! Dlen, dlen! — passa o bonde.” (p. 65) 
Entretanto, quando Kharms realiza tais jogos sonoros através da criação de palavras ou apropriando-se do vocabulário de uma outra língua, sem a intenção de empregar onomatopeias existentes e comumente utilizadas na língua russa, optamos pela estratégia de manter em português tal qual está no texto original. Assim, acontece quando a personagem do editor em "O professor Trúbotchkin" lê um poema em "fistolkiano" (invenção kharmisiana):

Jik, jik, jik

Foc, foc, foc,

Ric, ric, ric,

Chuk, chuk, chuk. (p. 100)

O mesmo podemos observar na linguagem indígena usada por Kolka Pánkin e Pietka Erchov, em que aparece o uso do xingamento em finlandês "perkilia":

-Perkilia! - gritaram os aborígenes.

— Kulmeguinki! — gritou Kolka.

— Perkilia, perkilia! — gritaram os aborígenes.

— Corre! — gritou Pietka. — Eles querem briga. (p. 46)

Nesses últimos casos, apenas transliteramos as mesmas palavras já empregadas no original por Kharms, para nosso alfabeto latino; este procedimento foi suficiente para garantirmos nas traduções os mesmos efeitos sonoros alcançados pelo escritor, no texto russo.

Já no que diz respeito às expressões idiomáticas, procuramos adequá-las ao português sempre que encontrávamos equivalente em nossa língua. Podemos citar como exemplo, o que os interlocutores da velhinha lhe diziam, em "Como uma velhinha comprava tinta", acerca de seu estado de alheamento do mundo. Assim, temos no texto em russo literalmente a expressão "cair da lua" - с луны свалить [s luní svalít] -, usada para caracterizar uma pessoa distraída, alheia ao universo que a cerca. Nesse caso, 
empregamos a expressão correspondente, em português, "viver no mundo da lua". Na mesma história, o narrador diz que "não havia nem sinal" de quem ajudara a velha atravessar a rua: “а его уж и след простыл”[а іеvó иј i slied prostíl], que pudemos traduzir por "sumira sem deixar rasto" (p. 65).

Ao longo da leitura, encontramos diversas referências às revistas nas quais as histórias de Kharms eram publicadas: Tchij e Ioj. Mantivemos seus nomes sem alteração, em russo, exceto na primeira história dessa coletânea, pelo fato do substantivo "tchij" (чиж) deixar de fazer menção ao título da publicação para referir-se ao pássaro visto no zoológico: o pintassilgo. "Então, vou lhe dizer: é um pintassilgo. — Ah, bom! Isso mesmo é o pintassilgo!” (p. 23)

A rima, recurso comumente visto na LIJ, é empregada com parcimônia pelo escritor e não chega a constituir-se numa marca de seu estilo no conjunto de sua prosa infantil. Algumas delas conseguimos reproduzir. Vejamos o exemplo da quadrinha em "O fusível travesso", com esquema rimático A/ B/ C/ B:

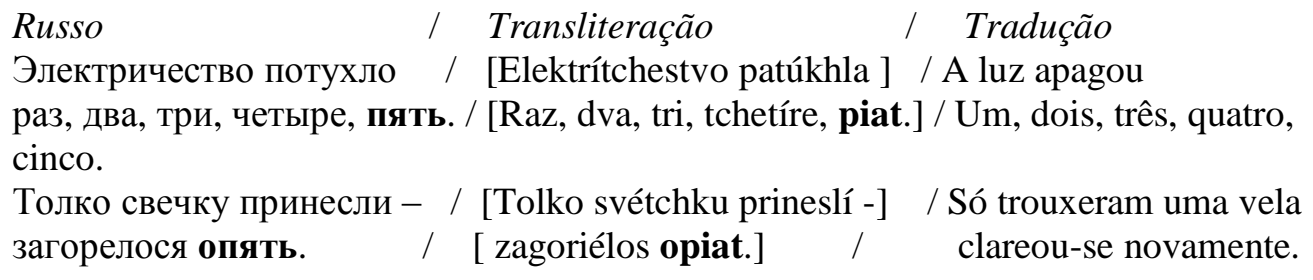

Conseguimos recuperar a rima existente no verso entre as palavras “пять” (piat) е “опять” (opiat) da seguinte maneira:

A luz acabou

Um, dois, três, quatro, cinco.

Foi só trazerem uma velinha,

Clareou-se, de novo, o recinto. (p. 28)

Entretanto, houve casos em que não conseguimos chegar a uma solução satisfatória, capaz de manter fidelidade aos elementos russos do texto e, ao mesmo tempo, 
buscar os efeitos de reiteração dos sons. É o exemplo do que acontece em "No ano passado fui comemorar o ano novo...”, onde optamos por manter o conteúdo do texto, conservando na tradução a substantivação do texto kharmisiano, visto que, para recriação do efeito das rimas seria necessário emprego de palavras estranhas tanto à narrativa, quanto à cultura russa.

Na festa de Iáchka joguei quadrado mágico, na festa de Churka brinquei de esconde-esconde, na festa de Ninka olhei ilustrações, na festa de Valódia dancei na roda, na festa de Lisavieta comi bombons de chocolate, na festa de Pávlucha comi maçãs e peras (p. 126)

Originalmente, rimas internas formadas entre o nome das crianças e o das brincadeiras por elas realizadas, conferem sonoridade e lirismo à historieta.

Algumas das histórias são iniciadas ou finalizadas por fórmulas que lhes conferem tom de oralidade e coloquialidade, por isso escolhemos as seguintes formas de tradução: “Era uma vez" - “жили были” [jili bili]; "certa vez”, "uma vez”, “de uma feita” “однажды” [odnájdi], “как-то” [kak-to], “вот” [vot]; “olha só essa história” “Вот так история” [vot tak istóriia]. Para as finalizações: “e como num passe de mágica” - “и что за чудo” [i chto za tchúdo] “(...) essa é uma outra história” - “об этом мы вам в следуюший раз расскажем" [ob étom mi vam v sliéduiuchi raz. rasskájem]; "acabou-se a história” - “всё” [vsio].

Quanto às marcas de oralidade presentes nas falas das personagens, realizamos adequações a medida em que foram necessárias para assegurarmos ao leitor de nossas traduções a compreensão do texto.

Nas passagens em que encontramos erros gramaticais, empregados propositalmente pelo escritor para caracterizar os tipos apresentados nas narrativas, procuramos reproduzir os efeitos similares na tradução. Por exemplo, em "Como uma velhinha comprava tinta", o jovem vendedor pertencente às classes populares, comete um erro de norma quando refere-se à moeda do país e, ao invés da variante culta "rublo" 
(рубль), ele diz “rub” (рупь). Dessa forma, traduzimos sua fala da seguinte maneira: “por um rubro é seu" (p. 62). No mesmo conto, o velho banguela de pronúncia sibilante acaba por modificar a grafia das palavras e diz à velhinha: "Chintcha che vende na locha" (p. 66). Efeito conseguido pelo escritor a partir inserção chiantes na sentença: “Шешuиu пошаются в макашише" [chechichi pocháiutsa v makachiche], quando a forma correta seria “чернила подадутся в магазине” [tcherníla podadútsa v magazíne] - tinta se vende na loja. Kharms também utilizou o erro gramatical, em "Era verão o sol brilhava", para evidenciar o gazeio da garça que diz a Platon: “Crale-se” (p 92.) (марчать, no lugar de молчать). Verificamos que, no original, a representação da voz do animal é conseguida pela inserção de uma vibrante " $\mathrm{R}$ " $(\mathrm{P})$ à palavra, traço que procuramos reproduzir em português.

Por fim, as adequações realizadas dizem respeito aos verbos russos e tempos verbais. Elas foram necessárias, tendo em vista que a língua russa não possui a mesma coesão temporal que o português. De modo que, uma história pode conter ações pretéritas que são narradas no presente, através da mescla de tempos verbais numa mesma oração. Por exemplo, em "O quebra-ossos" temos a seguinte passagem, traduzida literalmente: “O velhinho japonês olhou (посмотрел) para Vássia, esfregou (потёр) as mãos e diz (говорит)". Verificamos, então, que a tradução literal - com os verbos "olhar" e “esfregar" no passado, seguido de "dizer" no presente - não se adequa à gramática portuguesa por ausência de coerência verbal, enquanto que o texto russo não apresenta problemas de norma. Assim, ajustamos a tradução: "O velhinho japonês olhou para Vássia, esfregou as mãos e disse" (p. 116). Ao longo de nossas traduções inúmeras adaptações desse tipo foram realizadas, pois essa variação de tempos narrativos é uma marca da língua russa. Citamos mais um exemplo, retirado de "Os sete gatos", em que o narrador diz, literalmente: “fiquei (остался) sozinho com os gatos e penso (думаю)". 
Pelos mesmos motivos supracitados, traduzimos esta frase, ao final, por "fiquei sozinho com os gatos e pensei" (p. 129) 


\subsection{Contos infantis de Daniil Kharms}

— Você esteve no jardim zoológico? ${ }^{1}$

- Estive.

— Viu o leão?

- Aquele de tromba?

— Não, esse é o elefante, o leão não é assim.

— Ah, é aquele de duas corcovas?

— Também não! Com juba.

— Ah! Sim, sim, com juba, é aquele com bico.

— Mas que bico? Qual nada! Com presas.

— Ah, sim! Com presas e com asas.

— Não, esse não é o leão.

— Quem é então?

— Não sei. O leão é amarelo.

— Ah, sim, amarelo quase cinza.

— Não, está mais para vermelho.

— Sim, sim, sim, com rabo.

— Ah, sim, com rabo e garras.

— Sei! Com garras e do tamanho de um tinteiro.

— Mas que leão é esse! Está mais para rato.

— Nada disso! Não existe rato com asas.

— Mas esse é com asas?

—É sim!

\footnotetext{
${ }^{1}$ Na edição consultada o texto encontra-se sem data de publicação.
} 
— Mas, então é um pássaro.

— Isso mesmo. Eu também acho que é um pássaro.

— Eu estava falando com você sobre o leão.

— E eu também sobre o pássaro leão.

— E, por acaso, o leão é um pássaro?

— Para mim é um pássaro. Ele ainda chilreia bem assim:

"Tirli - tirli, tiu - tiu - tiu".

— Espere! É um cinzinha e amarelinho?

— Isso mesmo! Cinzinha e amarelinho.

— De cabecinha redonda?

—É, de cabecinha redonda.

- E voa?

- Voa.

— Então, vou lhe dizer: é um pintassilgo ${ }^{2}$.

— Ah, bom! Isso mesmo é o pintassilgo!

— E eu perguntei sobre o leão.

— Bom, o leão eu não vi.

\footnotetext{
2 Чиж (Carduelis spinus), m.q. pintassilgo. Ave passeriforme, da fam. dos fringilídeos (Fringilla coelebs), encontrada na Europa, Ásia e África, com cerca de $15 \mathrm{~cm}$ de comprimento, dorso e partes inferiores canela, alto da cabeça cinzento e uropígio verde [sin.: acalanto, batachim, chupim, pardal-castanheiro, pardal-deasa-branca, patachim, pimpalhão, pimpim, pinche, pintalhão, tentilhão-comum]
} 


\section{O fusível travesso}

$\mathrm{Na}$ Casa da criança 124, às oito horas em ponto, pôs-se a tocar o sino.

Jantar! Jantar! Jantar! Jantar!

Meninas e meninos desceram correndo a escada para o refeitório. Aos gritos, tropéis e gargalhadas ocuparam seu lugar.

Hoje na cozinha estão de plantão Arbúzov ${ }^{3}$ e Rubákin ${ }^{4}$, assim como, o professor Pável Kárlovitch ou Paukárlytch ${ }^{5}$.

Quando todos se acomodaram Paukárlytch disse:

— Hoje o jantar será sopa com kluski ${ }^{6}$.

Arbúzov e Rubákin trouxeram o caldeirão, colocaram-no em um tamborete e levantaram a tampa. Paukárlytch aproximou-se do caldeirão e pôs-se a gritar os nomes.

— Ivan Múkhin ${ }^{7}$ ! Nina Verióvkina ${ }^{8}$ ! Fedul Karapúzov ${ }^{9}$ !

Iam se aproximando, assim que chamados. Arbúzov despejava sopa no prato deles enquanto Rubákin dava um pãozinho. Tendo recebido uma e outra coisa, cada um ia para seu lugar.

— Kuzmá Parovózov ${ }^{10}$ ! — gritou Paukárlytch — Mikhail Topunov ${ }^{11}$ ! Zinaída Grebechkóva $^{12}$ ! Altofalante!

\footnotetext{
${ }^{3}$ Genitivo plural de арбуз (arbuz), melancia.

${ }^{4}$ Derivado de рубака (rubáka), espadachim.

${ }^{5} \mathrm{O}$ apelido do professor é formado pela junção entre seus nome e patronímico. Essa brincadeira linguística é uma das formas, em geral, utilizadas pelas crianças russas para denominar seus educadores de modo mais íntimo e, mesmo, carinhoso. Neste caso, optou-se por transliterar o apelido com a letra "u" (Paukárlytch) ao invés de "l" (Palkárlytch), visto que, em russo, a alcunha da personagem remete à palavra "palka" (палка) que significa pau, bastão, porrete.

${ }^{6}$ Em russo клёцки (kliotski), também chamado de kluski. É uma espécie de nhoque de origem polonesa, mas bastante comum em todos os países do leste europeu. Servido na sopa ou com leite.

${ }^{7}$ Referente à myxa (mukha), mosca.

${ }^{8}$ Referente à верёвка (veriôvka), corda ou barbante.

${ }^{9}$ Genitivo plural de карапуз (karapuz), boneco; diz-se também do menino pequeno e gracioso.

${ }^{10}$ Genitivo plural de паровоз (рагоvoz), locomotiva.

${ }^{11}$ Referente ao verbo monmamb (toptat), pisotear; diz também respeito à pisada do urso.

${ }^{12}$ Remete à гребёнка (grebionka), pente.
} 
Seriójka Tchikin ${ }^{13}$ era chamado de Altofalante, porque ele sempre falava a plenos pulmões e não conseguia conversar em voz baixa.

Quando Seriójka Altofalante aproximou-se do caldeirão, escureceu de repente.

— Acabou a luz! — puseram-se a gritar em diferentes vozes.

- Ai, ai, ai, veja lá o que está fazendo! - gritava mais alto do que todos o Altofalante.

—Altofalante está nadando na sopa. — gritava Kuzmá Parovózov.

— Cuidado para não se engasgar com o kluski. - gritou Piotr Sapogov ${ }^{14}$.

— Silêncio! Sentem em seus lugares. — gritou Paukárlytch.

— Devolva meu pãozinho! — gritou Zinaída Grebechkóva.

Nisso fez-se claro novamente.

— A luz voltou! — gritou Kuzmá Parovózov.

— Dá pra ver! — respondeu-lhe Zinaída Grebechkóva.

— Eu estou todo ensopado! — gritou Altofalante.

Quando se acalmaram um pouco, Paukárlytch começou a gritar de novo:

— Piotr Sapogov! Maria Gússeva ${ }^{15}$ ! Nikolai Pniov ${ }^{16}$ !

No dia seguinte, à noite, quando Paukárlytch mostrava às crianças o novo exercício de ginástica, escureceu de repente.

Fedul Karapúzov, Nina Verióvkina e Nikolai Pniov, repetindo os movimentos de Paukárlytch, escorregaram no escuro e caíram no chão.

-Piotr Sapogov aproveitou-se da escuridão e deu um soco nas costas de Altofalante.

Ao redor gritavam.

\footnotetext{
13 Alude ao verbo чикнуть (tchiknut), dar um golpe, acertar uma facada, acertar uma tesourada.

${ }^{14}$ Genitivo plural de canoz (sapog), bota.

${ }^{15}$ Referente a гусь (gus), ganso.

${ }^{16}$ Alude a neнь (pen), toco.
} 
- Acabou de novo! Acabou de novo! Traga uma lamparina! Já, já volta! E realmente a luz tornou a voltar.

— Foi você que me bateu? — perguntou Altofalante.

— Não vá pensando! — respondeu Sapogov.

— Aqui há algo de errado — disse Paukárlytch. — Você Múkhin e você Altofalante, corram ao prédio vizinho para saber se lá faltou luz como aqui, senão será preciso chamar o eletricista.

Múkhin e Altofalante saíram correndo e logo voltaram dizendo que, a não ser na Casa da Criança, a luz não tinha faltado.

No terceiro dia, desde bem cedo, o eletricista andava por toda a Casa da Criança com uma longa escada dupla e dobrável. Em cada cômodo ele abria a escada, subia nela, passava a mão em círculo pelo teto, pelas paredes, acendia e apagava diferentes lâmpadas; depois, por algum motivo, corria para o vestíbulo onde, sobre um cabide, ficava o medidor de energia e uma plaquinha de mármore com fusíveis. Atrás do eletricista andavam alguns meninos e observavam com curiosidade o que ele fazia. Finalmente, o eletricista, preparando-se para partir, disse que os fusíveis estavam com algum problema e, ao menor abalo, a luz podia acabar. Mas agora estava tudo bem, podia-se bater nos fusíveis até com um machado.

—É para bater mesmo? - perguntou Piotr Sapogov.

— Não, eu estava brincando — disse o eletricista. — Mas, em todo caso, agora a luz não acabará.

O eletricista foi embora. Piotr Sapogov ficou ali plantado, depois foi para o vestíbulo e permaneceu bastante tempo a olhar para o medidor e os fusíveis.

— O que você está fazendo aí? — perguntou-lhe Altofalante.

— O que te interessa? — disse Pietka Sapogov e foi para a cozinha. 
O relógio bateu duas horas, depois três, depois quatro, depois cinco, depois seis, depois sete e depois oito.

— Pois bem, — disse Paukárlytch — hoje não vamos ficar no escuro. Nossos fusíveis estavam com problema.

— E o que são esses fusíveis? — perguntou Maria Gússeva.

— Os fusíveis são chamados assim por causa de sua forma ${ }^{17}$. Eles...

Mas aí a luz acabou apagou e fez-se a escuridão.

— Acabou! - gritou Kuzmá Parovózov.

— Apagou! - gritou Nina Verióvkina.

— Já, já acende! — gritou Altofalante procurando no escuro por Pietka Sapogov para, fingindo ser sem querer, dar-lhe um tapa na nuca. Mas Pietka não estava ali. Em um minuto e meio, mais ou menos, a luz voltou de novo. Altofalante olhou ao redor. Nem sombra de Pietka .

— Amanhã chamaremos outro eletricista — falou Paukárlytch. — Esse não sabe de nada.

“Onde será que Pietka foi se meter?” — pensou Altofalante. — "Parece que hoje ele não faz plantão na cozinha. Tudo bem, depois me acerto com ele.”

No quarto dia foi chamado outro eletricista. O novo eletricista examinou os fios, os fusíveis e o relógio de força; subiu no sótão e disse que, agora sim, estava tudo em ordem.

À noite, perto das oito horas, a luz acabou de novo.

No quinto dia, a luz acabou quando todos estavam no clube desenhando o jornalmural. Zinaída Grebechkóva tinha derrubado uma caixinha com percevejos. Mikhail Topúnov correu para ajudá-la a recolhê-los, mas nisso a luz acabou e, na correria, Mikhail

\footnotetext{
${ }^{17}$ Em russo, a palavra "fusível" também significa rolha.
} 
Topúnov foi parar em cima da mesinha com a maquete de madeira da Isbá-biblioteca ${ }^{18}$. A Isbá-biblioteca caiu e se despedaçou. Trouxeram uma vela para ver o que tinha acontecido, mas a luz voltou.

No sexto dia, apareceu um desenho no jornal-mural da Casa da Criança 124, em que homenzinhos estavam de pé, com os braços abertos e uma mesinha caindo com uma casinha. Em baixo do desenho estava escrito:

A luz acabou

Um, dois, três, quatro, cinco.

Foi só trazerem uma velinha,

Clareou-se, de novo, o recinto.

Mas, apesar disso, à noite a luz acabou de novo.

No sétimo dia, chegaram de condução algumas pessoas à Casa da Criança 124. Paukárlytch guiou-as pela casa e contou sobre os caprichos da eletricidade. Os visitantes anotaram algo em suas cadernetas e partiram.

À noite a luz acabou.

E agora fazer o quê?

No oitavo dia, à noite, Serguei Tchikin, apelidado de Altofalante, levava réguas e um papel à sala de pintura que se encontrava em baixo, perto do vestíbulo. De repente, Altofalante parou. No vestíbulo, atrás da porta aberta ele avistou Piotr Sapogov. Na ponta dos pés, Piotr Sapogov olhando para os lados a todo momento, esgueirava-se até o cabide sobre o qual estavam o contador e a placa de mármore com fusíveis. Chegando ao cabide,

\footnotetext{
${ }^{18}$ Para possibilitar o acesso à leitura aos cidadãos das localidades mais afastadas do país, o governo soviético criara uma biblioteca, "Isbá-biblioteca" (изба-читальня). Sua arquitetura imitava uma isbá, casa típica camponesa e se constituía num espaço para empréstimo de livros, além de promover o desenvolvimento de atividades culturais. No contexto desta história, Kharms cita algumas das estratégias pedagógicas adotadas nas escolas soviéticas: a construção de maquetes que pudessem dar aos alunos noção dos projetos, construções do governo e, também, o jornal-mural (стенгазета) uma espécie de diário da turma, confeccionado pelas classes, com notícias, eventos, atividades etc.
} 
ele tornou a olhar ao redor e, agarrando os ganchos do cabide, de pernas apoiadas na bancada, trepou bem rápido e torceu um fusível. Tudo se apagou. No segundo andar ouviu-se um guincho e um grito.

No minuto seguinte, a luz tornou a voltar e Piotr Sapogov saltou do cabide.

— Pare! - gritou Altofalante soltando as réguas e agarrando Piotr Sapogov pelo ombro.

— Solta! — disse Pietka Sapogov.

— Não, não solto. Para que você desliga a eletricidade?

— Não sei — choramingou Piotr Sapogov.

— Não, mentira, você sabe! — gritou Altofalante. — Por sua causa derramaram sopa em mim. Você é um delinquente!

— Palavra de honra, naquela vez não fui eu que desliguei a força — disse Piotr Sapogov se soltando. - Daquela vez acabou sozinha. Mas quando o eletricista disse que dava para bater nos fusíveis até com um machado, daí à noite eu tentei bater em um fusível. De leve com a mão. E depois eu o segurei e o girei. Aí a luz acabou. Desde então, eu desligo todo dia. É interessante. Ninguém consegue consertar.

— Mas que bobo! — disse Altofalante. — Olha aqui, se desligar a força mais uma vez vou contar a todos. Nós organizaremos um Tribunal de camaradas ${ }^{19}$ e você vai ver só. E, por enquanto, para não se esquecer, toma! - e bateu em Pietka Sapogov do lado direito das costas.

\footnotetext{
${ }^{19}$ Uma das intenções do governo revolucionário era a substituição de instituições estatais tzaristas por organizações populares. Os tribunais de camaradas (товарищеский суд), mencionado por Altofalante, foram criados logo após a Revolução de 1917 e perduraram durante o período soviético. Sendo instaurados em fábricas, residências comunais, centros educativos etc., eram convocados a legislar sobre pequenas causas. cf. http://www.juridicas.unam.mx. Pesquisado em Fev./ 2015.
} 
Piotr Sapogov deu dois passos e levou um tombo, Altofalante recolheu o papel e as réguas, levou-os à sala de desenho e, como se nada disso tivesse acontecido, foi lá para cima.

No dia seguinte, o nono, Altofalante foi ter com Paukárlytch.

— Camarada professor, - perguntou ele — tenho permissão para consertar a força?

— E por acaso você sabe?

- Sei.

— Então, vá tentar. Talvez você consiga o que ninguém conseguiu.

Altofalante correu até o vestíbulo, trepou no cabide, remexeu, para disfarçar, perto do relógio, cutucou a plaquinha de mármore e destrepou de volta.

E como num passe de mágica! Daquele dia em diante, na Casa da Criança 124, a luz acende e não se apaga mais.

D. Bash 


\section{Em primeiro e em segundo lugar}

EM PRIMEIRO lugar, pus-me a cantar uma cantiga e fui andando.

EM SEGUNDO lugar, chega Pietka e diz: "Vou contigo". E fomos os dois cantarolando uma cantiga.

EM TERCEIRO lugar, estamos indo e, de repente, no meio do caminho, vemos um homem do tamanho de um baldinho.

“Quem és tu?" — perguntamos. — "Eu sou o menor homem do mundo". "Vamos juntos". — "Vamos".

E lá fomos nós, mas o homenzinho não conseguia nos acompanhar. Corria às pressas, mesmo assim ficava para trás. Daí lhe demos a mão. Pietka pela direita, eu pela esquerda. O homenzinho, pendurado entre nossas mãos, mal tocava o chão com os pés. E assim, lá fomos nós. Os três assobiando cantigas.

EM QUARTO lugar, estamos indo e, de repente, vemos à beira do caminho um homem deitado com a cabeça num toco, mas ele era tão comprido, que não dava para ver onde as pernas terminavam. Chegamos perto e, de repente, ele deu um pulo, acertando um soco tão grande no toco que o afundou na terra. O homem comprido olhou ao redor, avistou-nos e perguntou: "Vocês aí, quem são para perturbarem meu sono?" — "Nós somos a criançada alegre — dissemos. — Quer vir junto com a gente?” — "Está bem" — disse o homem comprido dando, de repente, um passo de quase vinte metros de uma vez. “Ei, - grita-lhe o homenzinho — espere um pouco por nós!” Agarramos o homenzinho e corremos até o comprido. "Não, — dissemos — assim não dá, ande com passos pequenos". 
O homem comprido foi com passos pequenos, mas a troco de quê? Caminhava dez passos e sumia de vista. "Então, — dissemos — deixa o homenzinho sentar nos seus ombros e você nos carrega debaixo do braço". O homem comprido acomodou o homenzinho em seu ombro, pegou-nos debaixo dos braços e seguiu em frente.

— "Tudo bem aí?" - pergunto a Pietka . "Tudo bem. E você?" — "Eu também" — disse eu. E nós começamos a assobiar alegres cantigas. O homem comprido, assobiando cantigas também, seguia em frente com o homenzinho em seus ombros, que também assobiava melodiosamente.

EM QUINTO lugar, estamos indo e, de repente, vemos um asno atravessado no caminho. Ficamos alegres e decidimos ir de asno. O primeiro a tentar foi o homem comprido. Ele passou a perna por cima do asno que nem chegava aos seus joelhos. Foi só o homem comprido querer sentar, que o asno, pumba, saiu andando. $\mathrm{O}$ homem comprido estatelou-se sentado no chão. Nós tentamos montar no asno o homenzinho, mas foi só o asno dar uns passos que ele, sem conseguir se segurar, caiu no chão. Depois levantou-se e disse: "Deixa o homem comprido me carregar de novo nos ombros e você vai de asno com Pietka ". Fizemos como tinha dito o homenzinho e seguimos adiante. E todos estavam bem. E todos nós assobiamos canções.

EM SEXTO lugar, chegamos a um grande lago. Vimos um barco à margem. "Que tal irmos de barco?" - perguntou Pietka . Eu e Pietka nos ajeitamos bem, no barco, mas o homem comprido teve dificuldades para se acomodar. Ele curvou-se todo, encolheu-se, encostando os joelhos no próprio queixo.

O homenzinho sentou-se num lugar qualquer debaixo do banco, só que não sobrou lugar para o asno. Se ao menos o homem comprido não estivesse no barco, daria para colocar o asno. Mas os dois juntos não cabiam. "Olha só, — disse o homenzinho — vai 
você, comprido, a vau. Nós colocaremos o asno no banco e vamos seguir". Acomodamos o asno no barco, o homem comprido foi a vau e ainda puxava nosso barco com uma corda. O asno estava com muito medo de se mexer, de certo, era a primeira vez que se via num barco. Mas os demais estavam bem. Seguimos pelo lago, assobiando canções. O homem comprido puxava nosso barco e também cantava canções.

EM SÉTIMO lugar, desembarcamos na outra margem e avistamos um automóvel. — “O que vem a ser isso?" — pergunta o homem comprido. — "O que é isso?” — pergunta o homenzinho. "Isso é um automóvel” — respondo. — "É o carro que usaremos agora" - disse Pietka . Acomodamo-nos todos no automóvel. Eu e Pietka nos sentamos ao volante, pusemos o homenzinho sobre o farol, mas não dava para acomodar o homem comprido, o asno e o barco juntos de jeito nenhum no automóvel. Colocamos o barco no carro, dentro do barco o asno e tudo estaria certo, se o homem comprido não estivesse sem lugar. Nós pusemos ele dentro do barco, mas o asno ficou sem lugar. Colocamos o asno e o homem comprido no automóvel, aí não havia nenhum lugar para o barco.

Ficamos totalmente perdidos, sem saber o que fazer, daí o homenzinho deu um conselho: "Talvez o homem comprido possa ir no automóvel, segurando o barco acima da cabeça e com o asno sentado em seus joelhos".

Sentamos o homem comprido no automóvel, pusemos o asno nos joelhos dele e demos o barco para ele segurar. "Não é pesado?" — perguntou-lhe o homenzinho. — "Não, de jeito nenhum" — disse o grandão. Pus o motor em marcha e nós seguimos.

Todos estavam bem, só o homenzinho estava sem conforto, sentado no farol, a balançar feito um joão-bobo por causa dos trancos. Mas os outros estavam bem. Seguimos e assobiamos canções. 
EM OITAVO lugar, chegamos a uma cidade. Seguimos pelas ruas. O povo olhava para nós apontando com o dedo e dizendo: "Olha só o varapau que vai sentado no automóvel, segurando um barco no alto e um asno no colo. Ha, ha, ha! E o do farol, então, do tamanho de um baldinho. Que piruetas ele dá por causa dos trancos! Ha, ha, ha!"

Daí chegamos direto ao hotel, deixamos o barco no chão, estacionamos o automóvel sob o toldo, amarramos o asno a uma árvore e chamamos o proprietário. Ele veio e perguntou: “O que desejam?” "É o seguinte, — nós lhe dissemos — é possível pernoitar por aqui?" — “É possível” — disse o proprietário e nos levou a um quarto com quatro camas. Eu e Pietka nos deitamos, só que o homem comprido e o homenzinho não conseguiam se deitar de jeito nenhum. Todas as camas eram curtas para o grandão e o homenzinho encostava no travesseiro, mais alto do que ele próprio, e acabava ficando em pé. Mas estávamos muito cansados, deitamos de qualquer jeito e caímos no sono. O grandão simplesmente foi para o chão, o homenzinho jogou-se em cima do travesseiro e dormiu assim.

EM NONO lugar, pela manhã acordamos e decidimos seguir caminho. Aí, de repente, o homenzinho falou: "Sabem de uma coisa? Chega de arrastar esse barco e esse automóvel. É melhor irmos a pé”. “A pé eu não vou, — disse o homem comprido — a pé se cansa rápido". — "Você, grandalhão desse jeito, vai se cansar?" — sorriu o homenzinho. "Claro que sim, - disse o comprido — seria bom achar um cavalo para o meu tamanho". "Qual cavalo lhe serviria? — interferiu Pietka. — Para você não seria cavalo, mas um elefante". "Mas aqui não dá pra arranjar um elefante, — disse eu — aqui não é a África”. Foi só eu dizer isso, de repente, escutamos na rua latidos, barulhos e gritos.

Olhamos pela janela, vimos andando pela rua um elefante e, atrás dele, um bando de gente se aglomerava. Bem nos pés do elefante, corria um cachorrinho, latindo com 
toda força, mas o elefante ia calmamente, não dava a menor bola para ninguém. "Veja, — o homenzinho disse ao comprido — há um elefante aqui para você. Monte e vá". — "E você pode montar no cachorrinho. É bem do seu tamanho" — disse o homem comprido. - "Verdade — concordo — o homem comprido vai no elefante, o pequeno no cachorrinho, eu e Pietka no asno". E corremos para a rua.

EM DÉCIMO lugar, saímos correndo para a rua. Eu e Pietka montamos no asno, o homenzinho ficou perto dos portões e o homem comprido correu atrás do elefante. Ao alcançar o elefante, montou nele e voltou para onde estávamos. E o cachorrinho não arredava pé do elefante, latia e também corria em nossa direção. Foi só o cachorro chegar até o portão, que o homenzinho pulou para cima dele. E lá fomos nós. À frente, o homem comprido, atrás dele, no asno, eu e Pietka e, por fim, o homenzinho no cachorrinho. Todos estávamos bem e todos assobiamos cantigas.

Saímos da cidade e prosseguimos, mas para onde fomos e o que lá aconteceu, já é uma outra história. 


\section{Os dezessete cavalos}

Em nossa aldeia morreu um homem e deixou para seus filhos o seguinte testamento.

Ao filho mais velho deixo $1 / 2$ da herança,

ao filho do meio deixo $1 / 3$ da herança e

ao filho mais novo deixo $1 / 9$ da herança.

E quando esse homem veio a falecer, sobraram 17 cavalos de tudo o que havia e nada mais. Os filhos puseram-se a dividir os 17 cavalos entre si.

“Eu - disse o mais velho - pegarei 1/2 de todos os cavalos. Significa que 17:2 dará $8 \frac{1}{2} . "$

- Mas como você vai levar esses 8 1/2 cavalos? - perguntou o irmão do meio. Você não está pensando em cortar os cavalos ao meio, ou está?

- Isso lá é verdade - concordou com ele o irmão mais velho - e vocês tampouco conseguirão pegar sua parte. Porque não é possível dividir 17 nem por 2, nem por 3, nem por 9 .

- Mas o que faremos?

- Vejam só, - isse o irmão caçula - eu conheço um homem bastante sábio chamado Ivan Petróvitch Rassudilov ${ }^{20}$, com certeza ele saberá nos ajudar.

- Então, vamos chamá-lo. - concordaram os outros dois irmãos.

O irmão caçula partiu para um lugar e logo voltou com um homem que vinha a cavalo e fumava um cachimbo curtinho. "Vejam, — disse o irmão caçula — este é Petróvitch Rassudilov."

\footnotetext{
${ }^{20}$ Referente ao verbo "rassudit” (рассудить), que significa julgar, conciliar.
} 
Os irmãos contaram a Rassudilov de sua desdita. O homem os escutou e disse: "Peguem o meu cavalo, assim vocês terão 18 cavalos e poderão dividir tranquilamente." Os irmãos começaram a dividir os 18 cavalos.

$$
\begin{aligned}
& \text { O mais velho pegou } 1 / 2-9 \text { cavalos, } \\
& \text { o do meio pegou } 1 / 3-6 \text { cavalos } \\
& \text { e o caçula pegou } 1 / 9-2 \text { cavalos. }
\end{aligned}
$$

Os irmãos somaram seus cavalos 9+6+2, que dá 17 cavalos. Já Ivan Petróvitch montou no seu $18^{\circ}$. cavalo e pôs-se a fumar seu cachimbo.

“E então, satisfeitos?” - ele perguntou aos surpresos irmãos e partiu.

D. Kharms 


\section{Como Kolka Pánkin voou para o Brasil e Pietka Erchov não acreditou em nada.}

Kolka Pánkin decidiu dar uma volta em algum lugar distante.

— Eu vou para o Brasil. — disse ele a Pietka Erchov.

— E onde fica o Brasil? — perguntou Pietka.

— O Brasil fica na América do Sul — disse Kolka — lá faz muito calor, lá têm macacos e papagaios, palmeiras, beija-flores, animais ferozes e tribos selvagens.

— Índios? - perguntou Pietka.

— Algo parecido com índios. — disse Kolka.

— E como se chega lá? — perguntou Pietka.

— De aeroplano ou de navio a vapor. — disse Kolka.

— E você vai de quê? — perguntou Pietka.

— Eu vou de aeroplano. — disse Kolka.

—E onde você vai conseguir um? - perguntou Pietka.

— Vou ao aeródromo, vou pedir e vão me dar. — disse Kolka.

— E quem é que vai te dar? — perguntou Pietka.

— Lá todo mundo me conhece. — disse Kolka.

— E quem é que você conhece lá? — perguntou Pietka.

— Muita gente. — disse Kolka.

— Não, você não conhece ninguém lá. — disse Pietka.

— Conheço, sim! — disse Kolka.

— Não conhece! — disse Pietka.

— Conheço, sim!

— Não conhece!

- Conheço! 
— Não conhece!

Kolka Pánkin e Pietka Erchov decidiram ir ao aeródromo, na manhã seguinte.

\section{II}

No dia seguinte, Kolka Pánkin e Pietka Erchov saíram de casa de manhã cedo. O aeródromo era longe, mas uma vez que o tempo estava bom e Kolka e Pietka não tinham dinheiro para o bonde, foram a pé.

— Eu vou mesmo para o Brasil. — disse Kolka.

—E você vai me escrever? — perguntou Pietka.

— Vou — disse Kolka — e quando voltar, vou trazer para você um macaco.

— E um passarinho também? — perguntou Pietka.

— E um passarinho também. — disse Kolka — O que você quiser, beija-flor ou papagaio.

— E qual é o melhor? — perguntou Pietka.

— O papagaio é melhor, ele sabe falar. — disse Kolka.

— E ele sabe cantar? - perguntou Pietka.

— Também canta. — disse Kolka.

— Seguindo partitura? — perguntou Pietka.

— Partitura ele não conhece. Mas aí você canta alguma coisa e o papagaio repete. — disse Kolka.

— E você vai mesmo me trazer um papagaio? — perguntou Pietka.

— Vou mesmo. — disse Kolka.

— Mas e se não trouxer? — perguntou Pietka.

— Eu disse que vou trazer, então, vou mesmo. — disse Kolka.

— Não vai! — disse Pietka.

— Vou sim! — disse Kolka. 
— Não vai! — disse Pietka.

— Não vai! — disse Pietka.

— Vou sim! — disse Kolka.

— Não vai!

— Vou sim!

— Não vai!

— Vou sim!

— Não vai!

Mas nisso, Kolka Pánkin e Pietka Erchov chegaram ao aeródromo.

\section{III}

O aeródromo era muito interessante. Os aeroplanos corriam pela pista um atrás do outro e aí — um, dois, três — já estavam no ar, primeiro em baixo, depois mais alto, depois mais alto ainda e depois de dar uma volta no mesmo lugar, sumiam de vez. Em terra ainda havia alguns aeroplanos que também estavam prestes a decolar e voar. Kolka Pánkin escolheu um deles e disse, mostrando-o a Pietka Erchov:

— Vou para o Brasil neste avião aqui.

Pietka tirou a boina e coçou a cabeça. Colocou a boina de novo e perguntou:

— Mas vão te dar este aeroplano?

— Vão sim. — disse Kolka — eu conheço um piloto lá.

— Conhece? E como ele se chama? — perguntou Pietka.

— Muito simples. É Pável Ivánovitch. — disse Kolka.

— Pável Ivánovitch? — Pietka quis saber.

— Pois é. — disse Kolka.

— E você vai pedir pra ele? — perguntou Pietka.

— Com certeza. Olha, vamos comigo e você vai ver como eu peço. — disse Kolka. 
— E se ele não te der o aeroplano? — perguntou Pietka.

— Como não vai dar! Se eu pedir ele vai dar. — disse Kolka.

— E se você não pedir? — perguntou Pietka.

— Vou pedir. — disse Kolka.

— Você não tem coragem! — disse Pietka.

— Tenho coragem, sim! — disse Kolka.

— Não, tem pouca! — disse Pietka.

— Tenho muita! — disse kolka.

— Não, tem pouca! — disse Pietka.

— Tenho muita! — disse Kolka.

— Tem pouca!

— Tenho muita!

- Pouca!

- Muita!

Kolka Pánkin e Pietka Erchov foram correndo até o piloto.

IV

O piloto estava do lado do aeroplano e lavava com gasolina alguns parafusinhos, dentro de uma bacia pequena. Ele estava todo vestido de couro, no chão ao lado estavam suas luvas de couro e um capacete de couro.

Kolka Pánkin e Pietka Erchov se aproximara. O piloto tirou os parafusinhos da gasolina, colocou-os bem na pontinha do aeroplano. Depois colocou na gasolina outros parafusos e começou a lavá-los. Kolka olhou, olhou e disse:

— Olá, Pável Ivánovitch!

O piloto olhou primeiro para Kolka, depois para Pietka e voltou ao que estava fazendo. Kolka esperou, esperou e tornou a dizer: 
— Olá, Pável Ivánovitch!

O piloto olhou primeiro para Pietka, depois para Kolka e daí, coçando uma perna com a outra, disse:

— Não me chamo Pável Ivánovitch, me chamo Konstantin Konstantínovitch e não conheço nenhum Pável Ivánovitch.

Pietka riu à socapa, Kolka deu-lhe uma cotovelada, Pietka fez cara séria e Kolka disse ao piloto:

- Konstantin Konstantínovitch, eu e Pietka decidimos voar para o Brasil, será que você pode nos emprestar o aeroplano?

O piloto começou a gargalhar:

— Ha, ha, ha, ha, ha, ha! É sério que decidiram voar para o Brasil?

—É. — disse Kolka.

— E você vai voar com a gente? — perguntou Pietka.

— E vocês estão pensando que eu vou deixar o avião na mão de vocês? — gritou o piloto - Não, estão enganados! Agora, se vocês me pagarem, posso levá-los ao Brasil, sim. O que vocês vão me dar?

Kolka vasculhou os bolsos, mas não achou nada.

— Dinheiro nós não temos — disse ele ao aviador — Quem sabe você não leve a gente assim mesmo?

— Não, assim não levo. — disse o piloto, virando-se para consertar qualquer coisa no aeroplano.

De repente, Kolka ergueu as mãos e gritou:

— Konstantin Konstantínovitch! Você quer um canivete? É muito bom, têm três lâminas. Na verdade, duas estão quebradas, mas uma está inteira e bem afiada. Uma vez, eu bati com ela de um jeito na porta que atravessou de um lado pro outro. 
— Quando foi isso? — perguntou Pietka.

— O que você tem a ver com isso? Foi no inverno! — Kolka ficou bravo.

— E que porta é essa que você furou de um lado pro outro? — perguntou Pietka.

— Aquela da despensa. — disse Kolka.

— Mas aquela está inteirinha. — disse Pietka.

—É que colocaram uma nova. — disse Kolka.

— Não colocaram, não. A porta é velha. — disse Pietka.

— Não, é nova. — disse Kolka.

— E você me devolve o canivete, — disse Pietka — ele é meu. Eu só dei para você cortar um varal com roupa e você o pegou de vez.

— Mas como assim, o canivete é seu? Ele é meu. — disse Kolka.

— Não, o canivete é meu! — disse Pietka.

— Não, é meu! — disse Kolka.

— Não, é meu! — disse Pietka.

— Não, é meu!

— Não, é meu!

— Então, está bem, deixa pra lá. — disse o piloto — sente-se no avião, criançada, vamos para o Brasil.

Kolka Pánkin e Pietka Erchov voaram de aeroplano para o Brasil. Isso foi pra lá de interessante. $\mathrm{O}$ aviador ia sentado na frente, só dava para ver seu capacete. Tudo foi muito bem, só que o motor fazia muito barulho e conversar era difícil. Quando se botava a cabeça para fora do avião, para olhar a terra, era tanto espaço, de tirar o fôlego! E na terra tudo era bem pequenininho, parecia tudo torto.

— Piet-ka! — grita Kolka. — Olhe, que cidade tortinha! 
— O que-e-e? — grita Pietka.

— A ci-da-de! — grita Kolka.

—Não estou ouvindo! — grita Pietka.

— O que-e-e? - grita Kolka.

— Será que o Bra-sil está perto? — grita Pietka.

— Que Vassi-lii ${ }^{21}$ ? - grita Kolka.

— O chapéu saiu vo-an-do! — grita Pietka.

— Quanto? — grita Kolka.

— On-tém! — grita Pietka.

— América do Norte! — grita Kolka.

— Na-vi-da-ri-di! — grita Pietka.

— Que-e? — grita Kolka.

De repente, deu um vazio nos ouvidos e o aeroplano começou a descer.

VI

Aos trancos e barrancos o aeroplano parou.

— Chegamos. - disse o piloto.

Kolka Pánkin e Pietka Ershov olharam ao redor.

— Pietka — disse Kolka — olha só como é o Brasil!

— E isso é o Brasil? — perguntou Pietka.

—É ele mesmo, seu bobo, por acaso não está vendo? — disse Kolka.

— E atrás de que está correndo aquela gente? — perguntou Pietka.

\footnotetext{
${ }^{21}$ No texto original encontramos as palavras: Brasília (Бразилия) е Vassilia (Василия), que significam respectivamente Brasil e Vassili. A falta de entendimento entre as personagens é possível, porque há rima entre os substantivos próprios (efeito que não recuperamos para não modificar os elementos russos do texto original); de modo que a aproximação sonora entre o que é dito e o que é, de fato, compreendido, possibilita o efeito cômico.
} 
— Onde? Ah, estou vendo. — disse Kolka — São aborígenes, selvagens. Tá vendo, eles têm as cabeças brancas. É que o penteado deles é de capim e palha.

— Por quê? — perguntou Pietka.

— Porque, sim. — disse Kolka.

— Eu acho que o cabelo é assim. — disse Pietka.

— Mas eu estou falando que são penas. — disse Kolka.

— Não, é cabelo! — disse Pietka.

— Não, são penas! — disse Kolka.

— Não, é cabelo!

— Não, são penas!

— Não, é cabelo.

— Bom, saiam do aeroplano — disse o piloto — preciso ir embora.

\section{VII}

Kolka Pánkin e Pietka Erchov saíram do aeroplano e foram ao encontro dos aborígenes. Os aborígenes eram baixinhos, sujos e louros desbotados. Ao avistarem Kolka e Pietka eles pararam. Kolka deu um passo à frente, levantou a mão direita e disse:

— Oakh! - disse-lhes em indígena. Os aborígenes ficaram boquiabertos e calados.

— Hapakuk! — disse-lhes Kolka, em indígena.

— O que é isso que você está falando? — perguntou Pietka.

— Estou falando com eles em indígena. — disse Kolka.

— E desde quando você sabe a língua indígena? — perguntou Pietka.

— É que lá em casa eu tinha um livrinho e aprendi por ele. — disse Kolka.

— Ah, conta outra! — disse Pietka.

— Pare — disse Kolka — Inam kos! — disse ele aos aborígenes em indígena. 
De repente, os aborígenes puseram-se a rir.

— Kerek ery iale. — disseram os aborígenes.

— Ara toki. — disse Kolka.

— Mita? - disseram os aborígenes.

— Deixa pra lá, vamos indo. — disse Pietka.

— Pilguedrau! - gritou Kolka.

-Perkilia ${ }^{22} !$ - gritaram os aborígenes.

— Kulmeguinki! — gritou Kolka.

— Perkilia, perkilia! — gritaram os aborígenes.

— Corre! - gritou Pietka. — Eles querem briga.

Mas já era tarde. Os aborígenes caíram em cima de Kolka e começaram a bater nele.

— Socorro! - gritou Kolka.

— Perkilia! — gritaram os aborígenes.

— Muu-uuu! - mugia uma vaca.

\section{VIII}

Depois de bater o quanto puderam em Kolka, os aborígenes pegaram pó, jogaram no ar e saíram correndo. Kolka ficou lá, desgrenhado e todo amassado.

- Pe-pe-pe-pe-Pietka! — disse ele em voz trêmula. — Que boa surra eu dei nesses abo-bo-borígenes. Toma uma aqui-i-i-i, toma outra lá-lá-lá.

— Mas não foram eles que deram em você? — perguntou Pietka.

— Que nada! — disse Kolka. — Eu ia agarrando um, depois outro; um, depois outro!

— Muu-uu! — ressoou bem junto ao ouvido de Kolka.

\footnotetext{
22 Xingamento em finlandês. cf. Kharms, D., 2011, p. 290.
} 
— Ai! — Kolka gritou e correu.

— Kolka! Ko-olka-a-a! — gritou Pietka.

Mas Kolka correu sem olhar par trás.

Correram que correram,

Correram que correram,

Correram que correram e só quando chegaram à floresta, Kolka parou.

— Ufa! — disse ele, respirando fundo.

Pietka ficou tão ofegante por causa corrida que não conseguia falar nada.

— Mas que bisão?! — Kolka disse retomando o fôlego.

— Hem? — perguntou Pietka.

— Você não viu o bisão! — perguntou Kolka.

— Onde? — perguntou Pietka.

— Lá, ora! Ele avançou pra cima da gente. — disse Kolka.

— Mas não era uma vaca? — perguntou Pietka.

— Que vaca que nada. No Brasil não há vacas. — disse Kolka.

— Mas será que os bisões andam com sininhos no pescoço? — perguntou Pietka.

— Andam. - disse Kolka.

— E de onde vêm esses sininhos? — perguntou Pietka.

— Dos índios. Os índios pegam o bisão, amarram um sininho nele e o soltam.

— Por quê? — perguntou Pietka.

— Porque, sim. — disse Kolka.

- Mentira, os bisões não andam com sininhos e aquilo era uma vaca. — disse Pietka.

— Não, era bisão! — disse Kolka.

— Não, era vaca! — disse Pietka. 
— Não, era bisão!

— Não, vaca!

— Não, bisão!

— E cadê os papagaios? — perguntou Pietka.

\section{IX}

Kolka Pánkin, de repente, chegou a ficar confuso.

— Que papagaios? — perguntou ele a Pietka Erchov.

- Mas você prometeu pegar para mim papagaios, assim que chegássemos ao Brasil. Se aqui é o Brasil, então aqui deve haver papagaios. — disse Pietka.

— Papagaio não dá pra ver, mas os beija-flores estão ali. — disse Kolka Pánkin.

—É aquilo lá no pinheiro? — perguntou Pietka.

— Isso não é pinheiro, é palmeira. — ofendeu-se Kolka.

— Mas, nos desenhos, as palmeiras são diferentes. — disse Pietka.

— Nos desenhos são diferentes, no Brasil são assim. — ficou bravo Kolka Olha só que beija-flores!

— Parecem com nossos pardais. — disse Pietka.

— Parecem — concordou Kolka — mas são menores.

— Não, maiores! — disse Pietka.

— Não, menores! — disse Kolka.

— Não, maiores! — disse Pietka.

— Não, menores! — disse Kolka.

— Não, maiores!

— Não, menores!

— Não, maiores!

— Não, menores! 
De repente, ouviu-se um barulho atrás de Kolka e Pietka.

\section{$\mathbf{X}$}

Kolka Pánkin e Pietka Erchov olharam para trás. Bem na direção deles vinha voando um monstro.

— O que é isso? — assustou-se Kolka.

—É um automóvel. — disse Pietka.

— Não pode ser! — disse Kolka. — Como um automóvel veio parar no Brasil?

— Não sei — disse Pietka — só sei que isso é um automóvel.

— Não pode ser! — disse Kolka.

— Mas estou dizendo que é um automóvel! — disse Pietka.

— Não pode ser! — disse Kolka.

— Pode! — disse Pietka.

— Não pode!

— Então, está vendo, agora, que é um automóvel? — disse Pietka.

— Estou vendo, mas é muito estranho. — disse Kolka.

Nesse ínterim o automóvel chegou mais perto.

— Ei vocês, criançada! — gritou um homem do automóvel - O caminho para Leningrado é a direita ou a esquerda?

— Para qual Leningrado? — perguntou Kolka.

— Como assim qual Leningrado?! Como se chega à cidade? — perguntou o motorista.

— Nós não sabemos. — disse Pietka e depois desatou a berrar — Titio — ele choramingou — leve a gente para a cidade.

— Mas vocês também são da cidade? — perguntou o motorista.

— Somos, sim. — berrou Pietka — da rua Mokhováia. 
— E como é que vieram parar aqui? — admirou-se o motorista.

— Foi o Kolka — berrou Pietka — que prometeu ir ao Brasil, mas viemos parar aqui.

— Em Brucílovo... Brucílovo... Esperem, Brucílovo é mais longe. Deve ser na Província de Chernígov. - disse o motorista.

- Província de Chilígov... República Chilena... Chile... Isso é mais ao sul, é lá onde fica a Argentina. O Chile fica às margens do Oceano Pacífico. — disse Kolka.

— Titio — tornou a choramingar Pietka de novo — leva a gente para casa.

— Está bem, está bem — disse o motorista — Podem entrar sentar, o carro está vazio. Só que Brucílovo não é aqui, Brucílovo é na Província de Chernígov.

E então, Kolka Pánkin e Pietka Erchov foram para casa de carro.

\section{XI}

A princípio, Kolka Pánkin e Pietka Erchov foram calados. Depois Kolka olhou para Pietka e disse:

— Pietka — disse Kolka — você viu o condor?

— Não — disse Pietka — O que é isso?

—É um pássaro. — disse Kolka.

— Grande? - perguntou Pietka.

— Muito grande. — disse Kolka.

- Maior do que o corvo? - perguntou Pietka.

— Imagina! É o maior dos pássaros. — disse Kolka.

— Eu não vi nenhum. — disse Pietka.

— Mas eu vi. Ele estava pousado na palmeira. — disse Kolka.

— Em que palmeira? — perguntou Pietka.

— Naquela onde estava o beija flor também. — disse Kolka. 
— Aquilo não era palmeira, era pinheiro. — disse Pietka.

— Não, era uma palmeira! — disse Kolka.

— Não, era um pinheiro! — disse Pietka — Palmeira só dá no Brasil, aqui não dá.

— Mas nós estivemos no Brasil. — disse Kolka.

— Não estivemos! — disse Pietka.

— Estivemos! - disse Kolka.

— Não es-ti-ve-mos! — gritou Pietka.

— Estivemos, estivemos, estivemos, esti-vemos! — gritou Kolka.

— Já dá para ver Leningrado — disse o motorista indicando com a mão as chaminés e os telhados que apontavam para o céu.

Acabou-se a história!

D. Kharms 


\section{A pena da águia dourada}

Ficou decidido que, logo após terminar a aula de alemão, todos os índios deveriam se reunir no corredor escuro atrás dos armários de equipamentos de física. Do corredor não dava para ver o que se fazia atrás dos armários e, por isso, os índios sempre se reuniam lá para discutir assuntos secretos. Esse lugar era chamado de "Desfiladeiro do Castor".

Os caras-pálidas não sabiam desse esconderijo secreto e reuniam-se onde fosse possível, ora no saguão, ora nos bancos do fundo da classe. <Mas em compensação, Grichka Tulónov, que era cara-pálida, tinha uma luneta de verdade.> Com essa luneta podia-se ver e observar tudo o que se fazia a longa distância. Os índios ofereceram aos caras-pálidas a troca do Desfiladeiro pela luneta, mas Grichka Tulónov recusou-se. Então, os índios declararam guerra aos caras-pálidas para tirar a luneta deles à força. Assim que acabasse a aula de alemão, os índios deveriam se reunir no Desfiladeiro do Castor para deliberações militares.

A aula já se aproximava do fim e, na classe, a tensão crescia cada vez mais. Os caras-pálidas podiam ser os primeiros a tomar o Desfiladeiro do Castor; do ponto de vista da situação militar isso era permitido.

Na segunda carteira estava sentado o chefe Comanche Gallapun Pulo da Fera ou, como o chamávamos na escola, Semion Karpiênko, pronto para pular de pé a qualquer instante. Ao lado de Gallapun estava sentado o índio Tchin-Gak-Khuk, grande chefe dos Araucanos. Ele fingia que copiava verbos alemães da lousa, mas o que fazia mesmo era escrever palavras indígenas para serem usadas em tempos de guerra.

Tchin-Gak-Khuk escreveu:

$$
\begin{aligned}
& \mathrm{Au}=\text { guerra } \\
& \mathrm{Kos}=\text { tribo } \\
& \text { Unem = grande }
\end{aligned}
$$




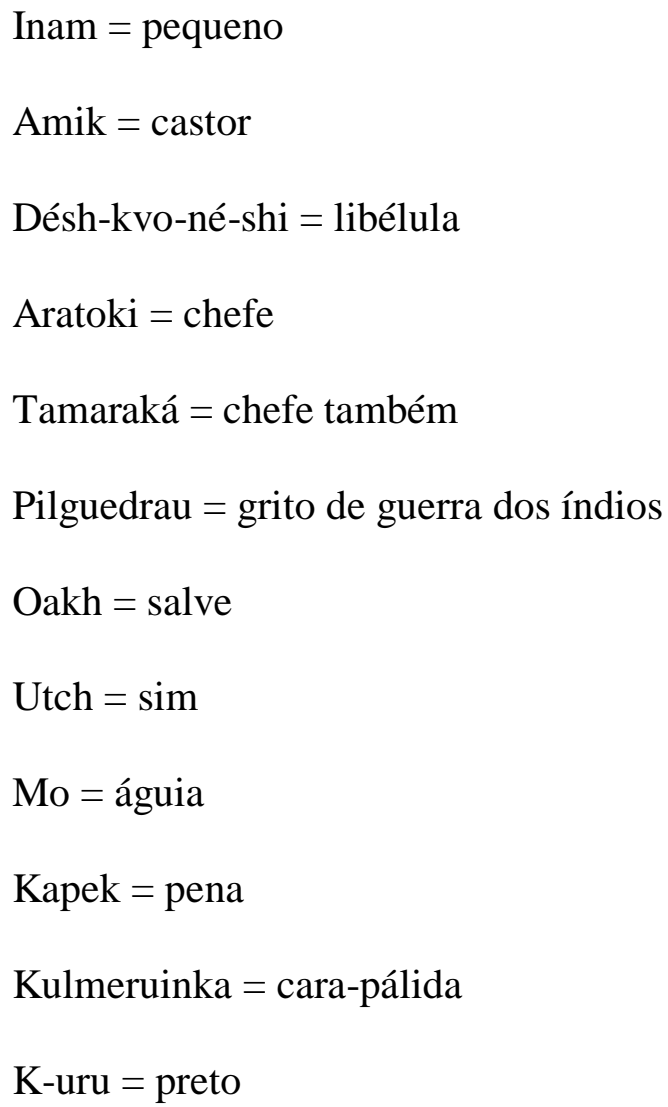

— Quantos minutos faltam para o sinal? — perguntou seu vizinho Gallapun.

— Oito e meio — respondeu Tchin-Gak-Khuk, mal movendo os lábios e olhando atentamente para a lousa.

— Isso quer dizer que hoje não haverá chamada oral. — disse Gallapun.

“É preciso falar com Nikítin para que, faltando uns dois minutos do sinal, ele peça permissão ao professor para sair da classe e se esconda no Desfiladeiro do Castor." pensou consigo Gallapun e, no mesmo instante, escreveu num pedacinho de papel a ordem e enviou-a a Nikítin pelo telégrafo.

Eram chamadas de "telégrafo" duas bobinas pregadas sob as carteiras, uma sob a carteira de Gallapun e a outra sob a carteira de Nikítin. Entre as bobinas havia uma linha esticada com uma caixinha de fósforos ligada a ela. Quando a linha era puxada a caixinha de fósforos deslizava de uma bobina a outra. 
Gallapun colocou sua ordem na caixinha e puxou a linha. A caixinha sumiu para debaixo da carteira e aproximou-se de Nikítin. Nikítin tirou a ordem de Gallapun de dentro e leu: "Gallapun, Pulo da Fera, chefe Comanche pede ao Curumilla para correr ao 'Desfiladeiro do Castor', dois minutos antes do fim do cativeiro alemão, e guardá-lo dos caras-pálidas.”

Embaixo da mensagem havia um desenho do cachimbo da paz, sinal secreto Comanche.

O Curumilla, ou como o chamavam os professores caras-pálidas, Nikítin leu a ordem de Gallapun e enviou a resposta: "Curumilla, Ouro Preto, executa pedido de Gallapun, Pulo da Fera".

Gallapun leu a resposta de Nikítin e acalmou-se. Agora Nikítin fará tudo o que um índio guerreiro deve fazer e os caras-pálidas não conseguirão tomar o Desfiladeiro.

— Bom, agora o Desfiladeiro é nosso. — cochichou Gallapun a Tchin-Gak-Khuk.

—É — disse Tchin-Gak-Khuk — isso se os mexicanos não nos atrapalharem.

— Quais mexicanos? — surpreendeu-se Gallapun.

— Pois veja só — disse Tchin-Gak-Khuk, desdobrando uma folha de caderno. Bem à sua frente está a planta de nossa escola e olhe aqui, é o mapa da América do Norte. Eu dei a cada classe nomes americanos. Por exemplo, no mapa o Alasca encontra-se acima, no canto direito, já na planta de nossa escola lá fica a classe D. Por isso, eu chamei a classe D de Alasca. As classes A e B de nossa planta ficam embaixo. Na América, aqui é bem onde fica o México. Nossa classe é o Texas e a classe dos caras-pálidas é o Canadá. Agora olhe aqui! - e Tchin-Gak-Khuk aproximou de Gallapun a folha de papel com aquela planta:

— Então, nós somos os texanos? — perguntou Gallapun.

—É claro! — disse Tchin-Gak-Khuk. 
— Parem de conversar! — gritou-lhes o professor. Tchin-Gak-Khuk pregou os olhos na lousa.

De repente, tocou o sinal. Schwartz e Nikítin saltaram de seus lugares.

— A aula ainda não acabou! — gritou o professor.

Schwartz e Nikítin sentaram-se.

— Pelo meu relógio ainda faltam três minutos para o sinal. — disse Tchin-GakKhuk.

— Então, seu relógio não está certo. — disse Gallapun. — Mas o que fazer? Os caras-pálidas podem tomar o Desfiladeiro.

— Para a próxima aula estudem $\S \S 14,15,16,17$ e 19 — ditava o professor.

No corredor, o barulho começava. Na classe $\mathrm{B}$, de certo a aula já devia ter terminado. Em breve, os índios também ficarão livres, mas e se de repente os caraspálidas saírem antes? Numa situação assim cada segundo é precioso.

— Bom, agora para o salão! — disse o professor.

Nikítin foi como que levado pelo vento, saiu voando da classe feito uma bala. Atravessando a porta de um salto, ele foi chocar-se de frente com Svistunov. Svistunov era o cara-pálida mais forte. Os caras-pálidas saíram da classe ao mesmo tempo que os índios e Svistunov correu para o Desfiladeiro. Gallapun saiu correndo da sala atrás de Nikítin. Ao ver Gallapun, Svistunov empurrou Nikítin e pôs-se a correr até o Desfiladeiro.

Mas não era à toa que Gallapun era chamado de Pulo da Fera. Mal Svistunov dera o quarto passo, já foi agarrado por trás pelas mãos fortes de Gallapun. Ao redor aglomeravam-se mexicanos, meninos e meninas olhavam, assistindo a briga dos dois gigantes.

— Hei-kho-khe! — ouviu-se o grito de Tchin-Gak-Khuk. Naquele momento, em que Gallapun lutava com Svistunov, Tchin-Gak-Khuk chegou correndo ao Desfiladeiro. 
— Hei-kho-khe! — gritou Tchin-Gak-Khuk.

Gallapun deixou Svistunov e juntou-se a Tchin-Gak-Khuk. O Desfiladeirodo Castor continuou em poder dos índios.

- Mais rápido, mais rápido! — apressou-se Tchin-Gak-Khuk — É preciso discutir os assuntos militares antes que o recreio acabe. Faltam quatro minutos.

Todos os índios já estavam reunidos. Nikítin montou guarda na entrada do Desfiladeiro e Tchin-Gak-Khuk disse:

- Peles-vermelhas! Nós todos, sem contar as meninas, somos onze pessoas. Mesmo que os caras-pálidas sejam em maior número, nós somos mais valentes do que eles. Eu tenho um plano de guerra. Eu o enviarei a vocês por telégrafo. Se vocês concordarem nós o proporemos aos caras-pálidas para que a guerra tenha regras. Agora eu proponho discutir um assunto. Ficamos preocupados o tempo todo durante as aulas pensando que os caras-pálidas vão tomar o Desfiladeiro. Isso atrapalha nossos estudos. Vamos agora propor aos caras-pálidas para não ocuparem o Desfiladeiro sem a gente. Quando estivermos aqui, então eles podem atacar. E na hora do sinal, quem estiver no Desfiladeiro irá ficar com ele no próximo recreio.

— Isso mesmo! — responderam em uníssono os peles-vermelhas.

— Quem vai conversar com os caras-pálidas? - perguntou Pirogov ou Piroga ${ }^{23}$, como os índios o chamavam e significa canoa.

— Que o Tchin-Gak-Khuk vá conversar! — gritaram os índios.

— Eu concordo! — disse Tchin-Gak-Khuk — Só que antes, alguém deve ir e avisar.

— Então, que vá o Piroga — disse alguém.

\footnotetext{
${ }^{23}$ Kharms emprega palavra indígena, possivelmente retirada das obras indigenistas de Gustave Aimard.
} 
— Está bem — disse Tchin-Gak-Khuk — só que os índios têm esse costume, se alguém vai em paz, deve levar consigo o cachimbo da paz. Eu tenho um.

Tchin-Gak-Khuk tirou do bolso um cachimbo pequeno, devia ser do pai dele. No cachimbo estavam presas com lacre penas de galinha.

— Dirija-se ao País dos Grandes Lagos e mostre esse cachimbo aos caras-pálidas — disse Tchin-Gak-Khuk a Piroga — depois, volte e traga um dos caras-pálidas junto com você. Eu vou conversar com ele no corredor escuro, na Califórnia, como eu o chamo. Piroga pegou o cachimbo da paz e saiu do Desfiladeiro. Ao entrar no corredor ele foi cercado pela multidão de mexicanos curiosos.

— Pirogov Nikolai vá pegar pardais! — gritaram-lhe os mexicanos. Mas Piroga foi com a cabeça erguida, assim como um índio verdadeiro deve andar.

No País dos Grandes Lagos havia muito barulho. Os habitantes robustos do Alasca corriam pelo salão brincando de pega-pega. Os mexicanos também estavam ali, mas são um povo pequeno, embora muito ágil.

Piroga avistou os caras-pálidas no canto. Estavam parados e combinavam alguma coisa. Piroga chegou mais perto deles. Os caras-pálidas se calaram e puseram-se a encarar Piroga.

Piroga estendeu-lhes o cachimbo da paz e disse:

— Oakh! — que significava saudações.

Da multidão de caras-pálidas saiu Grichka Tulónov.

— O que você quer aqui? — perguntou ele a Piroga franzindo a testa.

— Tchin-Gak-Khuk, chefe araucano, deseja falar com você — disse Piroga.

— Então, que venha — disse Grichka Tulónov — e o que é isso aí na sua mão?

— Este é o cachimbo da paz! — explicou Piroga. 
- Cachimbo da paz? E que tal isso aqui? - e Tulónov mostrou o punho para Piroga.

— Um de vocês deve ir tratar com Tchin-Gak-Khuk. — disse Piroga escondendo o cachimbo no bolso.

— Está bem, eu vou. — disse Svistúnov.

Piroga foi na frente e Svistúnov atrás, balançando os braços.

— Espere na Califórnia — disse Piroga a Svistúnov — que eu vou chamar TchinGak-Khuk.

Na entrada do Desfiladeiro, Piroga foi parado por Nikítin:

— Quem vem lá? — perguntou Nikítin.

— Sou eu. — disse Piroga.

— A senha? - perguntou Nikítin.

— Três maçãs. — disse Piroga.

— Passe. - disse Nikítin.

Tchin-Gak-Khuk já estava à espera de Piroga. Ele, imediatamente, pegou o cachimbo da paz e correu para a Califórnia. Nisso, o sinal bateu. Deviam ir para a classe.

Os índios sentaram-se cada um em seu lugar, mas Tchin-Gak-Khuk não estava. A aula de aritmética estava quase começando.

— Onde será que está Tchin-Gak-Khuk — agitou-se Gallapun.

— Será que eles brigaram? — disse Piroga.

— Eu vou lá ver — disse Gallapun e foi até a porta.

Mas não saiu da sala porque o professor já vinha andando pelo corredor. Gallapun sentou-se em seu lugar. O professor entrou na sala e sentou-se à mesa. 
Nessa hora, a porta silenciosamente abriu-se e fechou. De gatinhas, Tchin-GakKhuk correu rápido para baixo da carteira de Nikítin. O professor virou a cabeça para a porta, mas lá já não havia ninguém.

Gallapun ficou impressionado com Tchin-Gak-Khuk.

"Isso sim é que é índio!" — pensou ele.

De repente, algo sob a mesa bateu no joelho de Gallapun. Era a caixinha de telégrafo dos índios. Dentro dela havia um bilhete: "Chefe comanche Gallapun, deixe cair um lápis e comece a procurá-lo. Eu irei engatinhando até você. Chefe Araucano TchinGak-Khuk".

O professor começou a aula. A qualquer momento ele poderia dar pela ausência de Tchin-Gak-Khuk, por isso Gallapun, rápido, deixou cair um lápis e abaixou-se para pegá-lo.

No instante seguinte, Tchin-Gak-Khuk já estava sentado ao lado de Gallapun.

- Svistúnov concordou com tudo — disse ele a Gallapun. — Podemos ficar tranquilos que eles não vão tomar o Desfiladeiro sem a gente. Agora, é preciso enviar minhas regras de guerra a quem é dos nossos.

Tchin-Gak-Khuk pegou uma folha grande de papel e escreveu:

“Índios! Nós declaramos guerra aos caras-pálidas. Mas quem será o vencedor? Aquele que dominar o Desfiladeiro e a luneta? Isso vai dar em briga e nos expulsarão da escola. Eu proponho outra coisa. No jardim zoológico há uma jaula com uma águia.

De vez em quando a águia perde umas penas e os guardas as enfiam na portinha da gaiola, do lado de dentro. É possível pegar uma pena dobrando um aramezinho.

Hoje, depois do recreio maior, nós vamos ao jardim zoológico em excursão. Então, eu proponho considerar como vencedor aquele que tirar primeiro uma pena da águia. 
Eu já conversei com Svistúnov e ele vai passar isso aos caras-pálidas.

Chefe dos Araucanos, Tchin-Gak-Khuk."

Tchin-Gak-Khuk mostrou a Gallapun o plano de guerra e o colocou na caixinha do telégrafo. Logo o plano, assinado por todos os índios, voltou a Tchin-Gak-Khuk.

— Todos estão de acordo — disse Tchin-Gak-Khuk e pôs-se a escutar o professor atentamente.

— T-r-r-r-r! — pôs-se a tocar o sinal.

Os índios, sem pressa, anotaram a lição de casa e saíram da classe. Os caraspálidas já os aguardavam no corredor.

— Ei vocês! — gritaram os caras-pálidas. — É hora de lutar, entrem no Desfiladeiro que nós vamos arrancá-los de lá!

Gallapun saiu à frente e fez uma profunda reverência.

— Caras-pálidas! — disse ele. — O Desfiladeiro do Castor é grande o suficiente para alojar dentro dele vocês e nós também. Será que vale a pena brigar por causa dele, quando ele pode ser de quem sair correndo da classe primeiro? Eu proponho outra coisa. Vamos todos para o Desfiladeiro e discutiremos minha proposta.

E no Desfiladeiro se ajuntou tanta gente quanto podia caber lá dentro. 


\section{Como uma velhinha comprava tinta}

Na rua Kossobôkhaia, no prédio número 17, vivia uma velhinha. Em certa época ela vivia junto com seu marido e tinha um filho. Mas o filho ficou grande e foi embora. O marido morreu e a velhinha ficou só.

Ela vivia em paz e tranquilidade, bebia seu chazinho, mandava cartas ao filho e, de resto, não fazia nada.

Já os do prédio diziam que a velhinha vivia no mundo da lua.

No verão, a velhinha saia ao quintal de vez em quando, olhava ao redor e dizia:

— Ah, pai do céu, onde essa neve se meteu?

Os vizinhos punham-se a rir e gritavam-lhe:

— E onde já se viu neve cobrir o chão no verão? Onde está com a cabeça, vovó, por acaso você vive no mundo da lua?

Ou então, a velhinha ia à loja de querosene e perguntava:

— Quanto custam os pãezinhos franceses?

Os balconistas riam:

— Mas onde está com a cabeça, cidadã, desde quando temos pãezinhos franceses? Por acaso você vive no mundo da lua?

Prestem atenção como era a velhinha!

Certa vez o tempo estava bom, ensolarado, nenhuma nuvenzinha no céu. Na rua Kossobôkhaia levantou-se a poeira. Os inquilinos saíram para molhar a rua com esguichos de borracha com ponta de cobre. Eles jogavam água empurrando a poeira para o outro lado. O pó descia junto com a água na terra. Logo depois, cavalos já corriam pelas poças e o vento sem o pó voava limpo.

Do portão do prédio 17 saiu a velhinha. Em suas mãos, um guarda-chuva com cabo grande e brilhante, na cabeça um chapéu com lantejoulas pretas. 
— Por favor, — grita ela ao zelador — onde é que vendem tinta?

— O quê? — grita o zelador.

A velhinha mais de perto:

- Tinta! - grita.

— Saia da frente! — grita o zelador jogando água.

A velhinha foi para a esquerda e o jorro para a esquerda.

A velhinha foi mais do que depressa para a direita e o jorro atrás dela.

— Onde está com a cabeça, — grita o zelador — vive no mundo da lua? Não vê que estou a molhar a rua!

A velhinha acenou com o guarda-chuva e seguiu adiante.

A velhinha chegou à feira e viu um certo rapazote que vendia uma perca ${ }^{24}$ enorme e suculenta, do comprimento de um braço e da grossura de uma perna. Ele jogou o peixe para cima com as duas mãos, depois pegou com uma das mãos pela fuça sacudiu, sacudiu, soltou, mas sem deixar cair e com agilidade apanhou pelo rabo com sua outra mão e aproximou-o da velhinha.

— Olhe, — diz — por um rubro é seu.

— Não, — diz a velhinha — é de tinta...

Mas o rapaz não a deixou terminar.

— Pegue! — diz — Não estou pedindo muito.

— Não, — diz a velhinha — é de tinta...

O outro de novo:

— Pegue, — diz — o peixe pesa cinco funtes $^{25}$ e meio. — e, como se de cansaço, passou o peixe para a outra mão.

— Não, — disse a velhinha — é de tinta que preciso.

\footnotetext{
24 peixe.

${ }^{25}$ Funt: antiga medida de peso russa; 1 funt russo $=0,40951241 \mathrm{~kg}$.
} 
Finalmente, o rapaz escutou o que lhe dizia a velhinha:

— Tinta? - ele repetiu a pergunta.

- É, tinta.

- Tinta?

- Tinta.

— E de peixe não precisa?

— Não.

— Quer dizer que é tinta?

-É.

— Mas onde é que está com a cabeça, por acaso vive no mundo da lua?! — disse o rapazote.

— Quer dizer que tinta você não tem — disse a velhinha e seguiu adiante.

— Carne fresca, às suas ordens! - grita para a velhinha o robusto açougueiro e corta um fígado com uma faca.

— Tinta você não teria? — perguntou a velhinha.

— Tinta? - pôs-se a rugir o açougueiro, arrastando um leitão pela perna. A velhinha mais que depressa afastou-se do açougueiro, pois ele era demasiadamente gordo e furioso. E outra vendedora já lhe gritava.

— Aqui, por favor! Por favor, aqui!

A velhinha aproximou-se de sua barraca e pôs os óculos, pensando, enfim, ver a tinta.

A vendedora sorriu e estendeu-lhe uma lata com ameixas pretas.

— Veja só, por obséquio, — diz — destas você não acha em lugar nenhum.

A velhinha pegou a lata com as frutas, virou-a nas mãos e colocou-a de volta.

—É de tinta que eu preciso, não de frutas. — diz ela. 
— Qual tinta, vermelha ou preta? — perguntou a vendedora.

— Preta — diz a velhinha.

— Preta não tem — diz a vendedora.

— Bom, então, vermelha — diz a velhinha.

— Vermelha também não — disse a vendedora fazendo bico.

— Adeus — disse a velhinha e foi embora.

A feira ia terminando, mas não se via tinta em lugar algum.

A velhinha saiu da feira e foi andando por uma rua.

De repente, viu andando, com passos lentos, quinze burros um atrás do outro. No asno da frente estava sentado um homem alto que segurava uma imensa bandeira. Do mesmo modo, nos outros asnos pessoas também seguravam cartazes.

“O que será isso?" — pensa a velhinha. — "Pode ser que agora se ande tanto de burro, quanto de bonde."

— Ei! - ela gritou para o homem sentado no primeiro asno - Espere um pouquinho. Diga lá, onde é que vendem tinta?

Mas o homem montado no asno não escutou; não deve ter ouvido o que a velhinha lhe falava e levantou uma espécie de tubo com uma ponta estreita e outra larga feito uma boca de corneta. Apoiou na boca a ponta estreita, daí pôs-se a gritar de lá bem na cara da velhinha, tão alto que dava para ouvir a sete léguas:

CORRAM PARA VER O ESPETÁCULO DUROV!

NO CIRCO ESTATAL! NO CIRCO ESTATAL!

OS LEÕES MARINHOS PREDILETOS DO PÚBLICO!

ÚLTIMA SEMANA!

INGRESSOS NA ENTRADA! 
De susto, a velhinha até deixou o guarda-chuva cair. Ela levantou o guarda-chuva, mas as mãos tremiam tanto de medo que o guarda-chuva tornou a cair.

A velhinha apanhou o guarda-chuva, segurou-o com mais força e bem depressa, mais que depressa, seguiu caminho, calçadas afora, virando de uma rua na outra, indo sair numa terceira, larga e muito barulhenta.

Ao redor o povo corre para todos os lados, na via correm os carros e o bonde zune.

Foi só a velhinha querer atravessar para o outro lado, de repente:

— Fon, fon, fon! — grita o carro.

A velhinha deixou-o passar e, foi só pôr o pé na rua, gritaram:

— Ei, cuidado! - grita um cocheiro.

A velhinha deixou-o passar e mais do que depressa correu para o outro lado. Chegou correndo até o meio da via, nisso:

— Dlen, dlen! Dlen, dlen! — passa o bonde.

A velhinha recuou e atrás dela:

— Prum, prum, prum! — estronda a motocicleta.

A velhinha ficou toda assustada, mas ainda bem que uma boa alma apareceu, agarrou-a pelo braço e disse:

— Onde está com a cabeça? — diz. — Parece que vive no mundo da lua! A senhora pode ser atropelada!

E puxou a velhinha para o outro lado. A velhinha resfolegou e mal ia perguntarlhe pelas tintas, olhou em volta e a boa alma sumira sem deixar rasto.

A velhinha seguiu adiante apoiando-se no guarda-chuva, olhando para todos os lados para saber onde havia tintas. Ao seu encontro vinha um velhote com um cajado. Bem velhinho e grisalho.

A velhinha aproximou-se dele e disse: 
— O senhor, pelo visto é um homem vivido, não saberia onde vendem tinta?

O velhote parou, levantou a cabeça, mexeu suas ruguinhas e pôs-se a pensar. Daí parando um pouco, ele meteu a mão no bolso, tirou uma tabaqueira, um papel de fumo e uma piteira. Depois enrolando devagar o cigarro e colocando-o na piteira, guardou a tabaqueira de volta com o papel e pegou os fósforos. Então, começou a fumar o cigarro e, guardando os fósforos, chiou com a boca banguela.

- Chintcha che vende na locha.

A velhinha não entendeu nada e o velhote seguiu caminho.

A velhinha pôs-se a pensar.

Por que será que ninguém sabe dizer nada direito sobre tinta.

Será que nunca ouviram falar de tinta?

E a velhinha decidiu passar numa loja e perguntar de tinta. Ali hão de saber. E, bem ao lado, havia uma loja. Janelas grandes tomando toda a parede. E nas janelas só havia livros.

“Ó, — pensa a velhinha — é ali que eu vou. Lá com certeza tem tinta, já que há livros. Pois esses livros aí são escritos com tinta, né?"

Aproximou-se ela das portas, portas de vidro estranhas aquelas.

A velhinha empurrou a porta e eis que, por trás, algo a empurrou.

Virou-se para olhar e outra porta de vidro vinha em sua direção. A velhinha foi para frente e a porta atrás dela. Tudo ao redor era de vidro e tudo girava. A cabeça da velhinha pôs-se a girar, ela mesma não sabia para onde estava indo.

Em volta só havia portas, portas, todas elas giravam e empurravam a velhinha para frente.

A velhinha ficou marcando passo ao redor daquilo, livrando-se a tanto custo que por pouco não morre. 
A velhinha olha e à frente há um relógio grande e uma escada que sobe. Ao lado do relógio há um homem. Dirigindo-se até ele a velhinha pergunta:

— Onde poderia me informar sobre tinta?

Mas ele nem se dignou a olhar para ela, apenas apontou para uma portinha pequena gradeada. A velhinha abriu a portinhola devagarinho, entrou por ela e viu um recinto bem minúsculo feito um armário. E no recinto havia um homem. Mal ia a velhinha perguntar-lhe sobre tinta...

De repente: “Dim! Dimmm.” — e o chão começou a subir.

A velhinha não tinha coragem de se mexer e era como se uma pedra apertasse seu peito. Lá ficou ela sem conseguir respirar. Passaram através da portinha as mãos, as pernas e a cabeça de alguém e, de repente, fez um zumbido igual de máquina de costura. Depois parou de zumbir e ficou mais fácil de respirar. Alguém abriu a portinha e disse:

— Passem, por favor, não dá mais pra subir, sexto.

A velhinha, como que em sonho, deu um passo acima para um lugar onde lhe indicaram, atrás dela a porta bateu e o recinto-armarinho foi para baixo de novo. A velhinha ficou ali segurando o guarda-chuva nas mãos, mas não conseguia recuperar o fôlego. Lá ficou ela na escada, pessoas passaram ao redor batendo as portas e a velhinha lá ficou parada com o guarda-chuva na mão.

A velhinha esperou um pouco, olhou o que acontecia e entrou por uma das portas.

A velhinha foi parar numa sala grande e iluminada. Na sala, viu mesinhas e, às mesinhas, pessoas sentadas. Umas, com a cara metida no papel, escreviam algo e outras batiam nas máquinas de escrever. O barulho era como o de uma serralheria, só que de brinquedo.

À direita, perto da parede, havia um sofá. No sofá, estavam sentados um gordo e um magro. O gordo contava algo para o magro e esfregava as mãos, já o magro, todo 
curvado, olhava para o gordo através dos óculos de armação clara e amarrava os cordões de suas botas.

— Pois é, — disse o gordo — escrevi uma história sobre um menino que engoliu uma rã. Uma história interessantíssima.

— Eu, por minha vez, não consigo imaginar nada para escrever. — disse o magro, enfiando o cordão pelo buraquinho.

- Mas a minha é uma história muito interessante — disse o gordo. - $\mathrm{O}$ tal menino chegou a casa, o pai perguntou-lhe onde estava e de dentro da barriga a rã responde: Croac, croac! Ou na escola: o professor pergunta ao menino como é "bom dia" em alemão? E a rã responde: Croac, croac! O professor ralha e a rã: Croac, croac! Veja só que história engraçada — disse o gordão e esfregou as mãos.

— A senhora também escreveu alguma coisa? — perguntou ele a velhinha.

— Não — disse a velhinha. — Toda a minha tinta se foi. Eu tinha uma latinha que sobrara do filho, só que agora também acabou.

— O que, seu filho também é escritor? — perguntou o gordão.

— Não, — disse a velhinha — ele é guarda florestal. Só que ele não mora aqui. Antes eu pegava tinta do meu marido, agora o marido morreu e eu fiquei sozinha. Será que é possível comprar tinta aqui de vocês? — disse a velhinha de repente.

O magro amarrou suas botas e olhou para a velhinha através dos óculos.

— Como assim, tinta? — ele admirou-se.

— Tinta para escrever. — esclareceu a velhinha.

— Mas aqui não se vende tinta. — disse o gordo e parou de esfregar as mãos.

— Como a senhora veio parar aqui? — perguntou o magro, levantando-se do sofá.

— Vim de armário. — disse a velhinha.

— Que armário? - perguntaram a uma só voz o gordo e o magro. 
— Naquele que sobe e desce, ali perto da escada. — disse a velhinha.

— Ah, de elevador! — riu o magro, sentando-se novamente no sofá porque agora sua outra bota tinha desamarrado.

— E a senhora veio aqui por quê? — o gordo perguntou à velhinha.

— É que não consegui encontrar tinta em parte alguma, — disse a velhinha perguntei para todo mundo, ninguém sabia. Aí, vi uns livros aqui e entrei. Os livros são escritos com tinta, né?

— Ha, ha, ha! — gargalhou o gordo — Parece que a senhora vive no mundo da lua!

— Ei, escute! - o magro deu um pulo do sofá, de repente. Nem terminou de amarrar as botas e os cordões se arrastavam pelo chão.

— Escute - disse ele ao gordo. - Pois vou escrever sobre a velhinha que comprava tinta.

— Está bem — disse o gordo esfregando as mãos.

O magro tirou seus óculos, deu neles uma bafejada, enxugou com um lenço, colocou-os no nariz de novo e disse à velhinha:

- Conta para nós sobre como você comprava tinta, nós vamos escrever um livrinho sobre a senhora e lhe daremos tinta.

A velhinha pensou um pouco e concordou.

E então o magro escreveu o livrinho:

Como uma velhinha comprava tinta. 
Certa vez, o leão, o elefante, a girafa, a rena, o avestruz, o alce, o cavalo selvagem e o cachorro discutiram sobre quem dentre eles todos corria mais rápido.

Discutiram, discutiram, discutiram e, por pouco, não brigaram.

Gricha Apielsínov ${ }^{26}$ ouviu a discussão dos animais e disse-lhes:

— Ai, vocês, bichos bobos! Que discussão mais inútil! Seria melhor fazer uma competição. Quem der a volta primeiro no lago é o campeão e corre mais rápido de todos.

Os bichos concordaram, só o avestruz disse que não sabia correr ao redor do lago.

— Então, não corra! — disse-lhe o alce.

- Mas eu vou correr! - disse o avestruz.

— Então, corra! — disse a girafa.

Os bichos puseram-se em fila, Gricha Apielsínov agitou a bandeira e os bichos saíram correndo.

O leão deu alguns pulos, cansou-se e foi descansar debaixo das palmeiras. Os outros bichos continuaram a correr. À frente de todos, a toda velocidade, corria o avestruz e, atrás dele, o alce e a girafa. Daí o avestruz ficou com medo de ser ultrapassado pela girafa e pelo alce, virou a cabeça para eles e gritou:

— Ei, escutem! Vamos beber toda a água do lago! Todos os bichos vão correr em volta do lago, enquanto nós, correndo direto pelo fundo seco, chegaremos antes de todos.

— É isso mesmo! — disseram o alce e a girafa; pararam e começaram a beber a água do lago.

E o avestruz pensou consigo:

\footnotetext{
${ }^{26}$ Genitivo plural de апельсин (apielsin), laranja.
} 
— Que burros! Eles que bebam a água, eu continuo a correr.

E o avestruz continuou a correr, só que se esqueceu de desvirar a cabeça e, ao invés dele correr para frente, correu para trás.

\section{III}

E o alce e a girafa beberam, beberam, beberam, beberam e finalmente, a girafa disse:

— Não aguento mais.

E o alce disse:

— Eu também não aguento mais.

Eles continuaram a correr, só que não conseguiam correr rápido. De tanta água que tinham bebido.

E o elefante viu isso e desatou a rir!

Parava e ria! Parava e ria!

E o cachorro foi devorado pelas pulgas ao longo do caminho. Sentou-se e começou a se coçar!

Sentava e coçava! Sentava e coçava!

De modo que a rena e o cavalo selvagem foram os primeiros a chegar.

IV

E o tal do elefante só parava e ria!

$\mathbf{V}$

E o tal do cachorro só sentava e coçava! 
E a tal da girafa só fazia correr!

VII

E o tal do elefante só fazia rir!

VIII

E o tal do cachorro só fazia coçar-se! 


\section{A lebre e o ouriço}

Certo vez, um ouriço deu um passo em falso e caiu num rio. A água do rio estava gelada e o ouriço ficou com muito frio. O ouriço queria se aquecer no sol, mas o tempo estava fechado, o sol encoberto pelas nuvens.

O ouriço sentou-se numa clareira e ficou a esperar que o sol aparecesse detrás das nuvens.

O ouriço estava sentado na clareira. Pingava água dele. Estava com frio.

De repente, viu uma lebre correndo pela clareira:

— Ei, lebre! — gritou o ouriço — Venha cá!

A lebre aproximou-se do ouriço e disse:

— Você me chamou para quê?

— Olha — disse o ouriço — há tempos quero falar com você. Todos dizem que você é medrosa. Você não tem vergonha disso?

— O que deu em você? — surpreendeu-se a lebre. — Por que você está me ofendendo?

— Porque — disse o ouriço — você é medrosa e eu quero ensinar a você como ficar valente.

— Eu sou muito valente, mesmo sem sua ajuda — disse a lebre. — Eu já não tenho medo de nada mesmo.

— Não, — disse o ouriço. — você é medrosa, agora eu...

O ouriço, de repente, calou-se, abriu a boca, fechou os olhos e levantou a cabeça. A lebre olhou para o ouriço e assustou-se.

— O que há com ele? — pensou a lebre. — Ele deve ser louco!

A lebre pulou para o lado e se escondeu num arbusto.

O ouriço balançou a cabeça para o lado e, de repente, espirrou: Atchim! 
Depois o ouriço enxugou o nariz com a patinha, abriu os olhos, olhou e viu: nada de lebre.

— Que brincadeira é essa?! — disse o ouriço. — Onde será que ela foi parar? Ei, lebre, cadê você?

A lebre sentada atrás da moita, ficou calada.

O ouriço pensou em ir para casa, mas parou de repente, fechou os olhos, abriu a boca um pouquinho, depois mais, depois mais ainda, de repente, sacudiu a cabeça para o lado e espirrou com força: Atchim!

— Saúde! — disse alguém perto do ouriço.

O ouriço abriu os olhos e viu a lebre a sua frente.

— Onde você estava? — perguntou-lhe o ouriço.

— Como, onde estava? - perguntou a lebre. - Em lugar nenhum. Estava aqui o tempo todo.

— Não pode ser. — disse o ouriço — Eu não vi você. Eu até gritei, mas você...

O ouriço, de repente, calou-se pôs seu nariz para frente, depois levantou-o, depois levantou-o mais alto, depois mais alto ainda, depois apertou os olhos, levantou o nariz mais alto ainda e, de repente, abaixou-o até o chão e espirrou com força: Atchim!

— Parece que estou ficando resfriado — disse o ouriço, abrindo os olhos. E de repente, viu que a lebre tinha sumido de novo.

O ouriço observou ao redor, coçou a cabeça com a patinha.

— Não — disse o ouriço - Essa lebre simplesmente... At... At... Atchim! — espirrou o ouriço.

—É a realização dos sonhos! — disse alguém ao lado do ouriço.

O ouriço abriu os olhos e viu a lebre.

— Mas o que é isso? — disse o ouriço esquivando-se da lebre. 
- O que? - perguntou a lebre.

— Escuta, — disse o ouriço — você ficou aqui o tempo todo?

— Sim. — disse a lebre. — Eu fiquei aqui o tempo todo.

— Então, não estou entendendo nada! — disse o ouriço. — Ora você desaparece, ora de novo... at... at... at... atchim!

O ouriço abriu um olho com cuidado, mas na mesma hora o fechou e abriu o outro. A lebre não estava.

— Ela sumiu de novo! — disse baixinho o ouriço, abrindo ambos os olhos.

— Não é uma lebre, mas simplesmente... at... at... at... atchim!

— Saúde! — disse a lebre bem no ouvido do ouriço.

— Socorro! Ajudem-me! — gritou o ouriço virando uma bola e botando seus espinhos afiados para todos os lados.

— Por que você está a gritar? — perguntou a lebre.

— Deixe-me! — gritou o ouriço. — Tenho medo de olhar para você! Você some o tempo todo! Eu não estou entendendo nada! Vá embora!

— Espere, — gritou a lebre — você queria me ensinar a ficar corajosa.

E com estas palavras, a lebre amoitou-se no arbusto, de novo.

- Para ficar corajoso - disse o ouriço, colocando o focinho para fora, mas, de repente, viu que a lebre tinha sumido de novo.

— Ai - ai - ai! De novo... atchim! Sumiu de novo. — gritou o ouriço e pôs-se a correr.

O ouriço corria, parava, espirrava e corria mais. Espirrava e corria, de novo.

A lebre saiu da moita e pôs-se a rir.

— Ha - ha - ha! — ria a lebre — Olha só que corajoso! Queria me ensinar a coragem! Ha - ha - ha! 
Quem me contou essa história foi um melro amigo meu.

Ele mesmo viu tudo isso. Porque estava numa árvore ali por perto.

(meados de 1930) 
Uma vez, comprei um lápis, fui para casa e sentei para desenhar. Foi só querer desenhar uma casinha que, de repente, tia Sacha me chamou. Eu deixei o lápis e fui até a tia Sacha.

— Você me chamou? - perguntei à titia.

— Sim — disse ela. — Olha isso aí na parede, é uma barata ou uma aranha?

- Para mim, é uma barata — disse e quis sair dali.

— Ora bolas! — gritou tia Sacha — Mate-a, então!

— Tudo bem — disse eu e subi na escada.

— Pegue esse jornal velho aqui — dizia a tia. — Pegue a barata com jornal e levea para debaixo da torneira no banheiro.

Eu peguei o jornal e me estiquei até onde estava a barata. Mas, de repente, a barata deu um estalo e pulou para o teto.

- I-i - i - i - i — guinchou tia Sacha e saiu correndo da sala.

Eu também fiquei com medo. Eu estava na cadeira e encarava o ponto preto no teto. O ponto preto rastejava devagar em direção à janela.

— Bória, você pegou? O que está acontecendo? — perguntou a tia detrás da porta com uma voz nervosa.

Daí, por algum motivo, virei a cabeça e, naquele mesmo segundo, pulei da cadeira e corri para o meio da sala.

$\mathrm{Na}$ parede, perto daquele lugar onde eu estivera, havia mais um inseto bem estranho, só que era maior, do tamanho de um fósforo e meio. Ele olhava para mim com dois olhinhos negros e mexia a boquinha parecida com uma flor.

— Bória, o que há com você? — gritava a tia lá do corredor.

— Aqui tem mais um! — eu gritei.

O inseto olhava para mim e respirava como um pardal. 
— Eca, que nojo! — eu pensei. Até cheguei a tremer dos pés à cabeça.

E se for venenoso? Eu não aguentei e, aos gritos, corri em direção à porta. Bastou fechar a porta atrás de mim que algo bateu com força nela, pelo lado de dentro da sala.

— É ele, — disse eu tomando fôlego. Titia já estava correndo para fora do apartamento.

- Eu não entro mais no meu apartamento! Não entro! Podem fazer o que quiserem, mas no apartamento eu não entro. — gritava titia, para os moradores do prédio que se amontoavam na escada.

- Mas diga, Aleksandra Mikháilovna, o que era? - perguntou Sierguiéi Ivánovitch do apartamento 53.

— Não sei, não sei, não sei! — gritou titia. Só que ele bateu tanto na porta que o chão e o teto estremeceram.

—É um escorpião. No sul nós temos um monte deles, disse a esposa do advogado do segundo andar.

— Pode ser, mas no apartamento eu não entro! — repetia titia Sacha.

— Cidadã! — gritou o homem de calça violeta, curvando-se do lance superior da escada. - Não somos obrigados a caçar escorpiões no apartamento dos outros. Vá ao zelador!

— Isso mesmo, é com o zelador! — exclamou com alegria a esposa do advogado.

Tia Sacha foi até o zelador.

Indo embora para seu apartamento, Sierguiéi Ivánovitch, do 53, disse:

— Só que isso não é escorpião. Primeiro, como um escorpião poderia parar aqui? Segundo, escorpiões não pulam.

(meados de 1930)

B. D. 
— Olha, Liénotchka, — disse a tia — vou sair, você fique em casa e seja boazinha, não puxe o rabo do gato, não coloque semolina no relógio da sala de jantar, não se balance na lâmpada e não beba tinta química. Está bem?

— Está bem — disse Liénotchka pegando nas mãos uma tesoura grande.

— Pois bem, — disse a tia — sairei e chegarei daqui cerca de duas horas e trarei para você balas de hortelã. Você quer balas de hortelã?

- Quero - disse Liénotchka, segurando a tesoura grande numa das mãos e pegando de cima da mesa o guardanapo com a outra mão.

— Então, até daqui a pouco, Liénotchka — disse a tia e partiu.

- Até logo! Até logo! — cantava Liénotchka - examinando o guardanapo. A tia já tinha saído e Liénotchka continuava a cantar sem parar.

— Até logo! Até logo! Até logo, tia! Até logo guardanapo quadrado! — cantava Liénotchka.

Dizendo isso, Liénotchka pôs a tesoura para trabalhar.

— E agora, e agora — pôs-se a cantar Liénotchka — o guardanapo ficou redondo! E agora semicírculo! E agora ficou pequenininho! Havia um guardanapo e agora ficaram muitos guardanapos pequenininhos!

Liénotchka olhou para a toalha da mesa.

— A toalha de mesa também é só uma! — pôs-se a cantar Liénotchka — Eis que agora serão duas! Agora viraram duas toalhas! E agora três! Uma grande e duas menores! Mas ora, a mesa continua sendo só uma!

Liénotchka disparou para a cozinha e trouxe um machado. 
— Agora de uma mesa nós faremos duas! — pôs-se a cantar Liénotchka, dando machadadas na mesa. Mas apesar de Liénotchka ter se esforçado muito, só conseguiu picar da mesa algumas lascas.

(meados de 1930) 
Os dois amigos, Kólia Kókin e Vânia Mókhin estão acampados com os Pioneiros ${ }^{27}$. Kólia Kókin é forte, grande e bem disposto, o melhor fisiculturista do acampamento. Vânia é fraco e magricela, não gosta de desporto. Em uma série de eventos Vânia Mókhin se mete em situações ridículas e estúpidas por ser fraco e desajeitado. Vânia é preguiçoso, ele gostaria de tornar-se forte logo de uma vez.

Graças a uma fantástica invenção científica, Vânia ficou extraordinariamente forte. Uma viga cai em sua cabeça e quebra-se em cacos, sem lhe causar danos. Com a mão ele consegue parar um trem e assim por diante.

Inesperadamente, quando ele chama seu amigo Kólia para uma luta essa força acaba. Mas agora que Vânia sabe como se sente uma pessoa forte começa a praticar desporto.

(meados dos anos 1930)

${ }^{27}$ Organização infanto-juvenil ligada ao partido comunista da qual a criança passava a fazer parte quando ingressava na escola; promovia atividades ao ar livre e ligadas aos esportes, além de doutrinação política. 
Volódia estava na festa de ano novo. Todas as crianças dançavam em roda, mas Volódia era tão pequeno que nem andar sabia.

Acomodaram Volódia em um cadeirão.

Nisso, Volódia viu uma espingarda: "Dá! Dá!” — grita. Mas “dar” o quê não consegue dizer, porque ele é tão pequeno que nem falar sabe.

E Volódia quer tudo: avião ele quer, automóvel ele quer, crocodilo verde ele quer. Quer tudo!

— “Dá! Dá!” — grita Volódia.

Deram para Volódia um chocalho.

Volódia pegou o chocalho e sossegou.

Todas as crianças dançavam ao redor da árvore de ano novo, mas Volódia sentado no cadeirão chocalha o chocalho.

Volódia gostou demais do chocalho!

(meados dos anos 1930)

Nota da tradutora: Na URSS deixou-se de comemorar o natal, de modo que os símbolos dessa festa religiosa foram adaptados para a Festa de Ano Novo. Segundo Orlando Figes (2007, p. 54), as árvores de natal foram definitivamente banidas em 1929. Por isso, nessa história as crianças brincam em torno da árvore, também chamada de Pinheiro de Ano Novo. 


\section{"Um atrás do outro"}

Chegou à nossa redação um homem de gorro de pele, botas de feltro e com uma enorme pasta embaixo do braço.

- O que o senhor deseja? - perguntou-lhe o redator ${ }^{28}$.

— Eu sou inventor. Meu sobrenome é Astatúrov — disse o que havia entrado. — Eu inventei um novo jogo para crianças. Ele se chama "Um atrás do outro".

- Mostre - disse o redator.

O inventor abriu a pasta, tirou dela um papelão e o estendeu sobre a mesa. No papelão estavam desenhados 32 quadrados: 16 amarelos e 16 azuis. $\mathrm{O}$ inventor tirou da pasta 8 figuras de cartão e colocou-as diante do tabuleiro.

— Pois bem, — disse o inventor — veja aqui as oito figuras: quatro amarelas e quatro azuis. Elas podem ser chamadas assim: a primeira figura representa uma vaca e chama-se "vaca".

— Perdão, — disse o redator — mas isso não é uma vaca.

— Isso não importa — disse Astatúrov. — A segunda figura é um samovar e chama-se "médico", as figuras amarelas e azuis são totalmente iguais.

— Permita-me, — disse o redator — mas o médico amarelo é bem diferente do azul.

— Isso não importa — disse Astatúrov. — Agora explicarei ao senhor como se joga esse jogo. São dois jogadores. Primeiro, eles colocam as peças nos lugares. As figuras amarelas nos quadrados amarelos, as azuis nos azuis.

— E depois? - perguntou o redator.

\footnotetext{
${ }^{28} \mathrm{Na}$ URSS, o redator possuía a função de zelar pela idoneidade ideológica dos textos a serem publicados nas editoras, portanto era responsável pela censura e edição dos textos.
} 
— Depois, — disse Astatúrov — os jogadores começam a mover as figuras. $\mathrm{O}$ primeiro move o samovar amarelo, o segundo, o samovar azul. Aos poucos, as figuras caminham umas ao encontro das outras e, enfim, trocam de lugar.

— E o que vem depois? — perguntou o redator.

— Depois, — disse Astatúrov — as figuras caminham de volta na mesma ordem.

— Mas e daí? - perguntou o redator.

— É tudo — disse Astatúrov solenemente.

— Trata-se de um jogo extremamente estúpido. — disse o redator.

— Como assim estúpido? — ofendeu-se o inventor.

- Para que ele serve? - perguntou o redator.

- Como passatempo — disse o inventor Astatúrov.

Nós não seguramos e desatamos a rir.

— Podem rir — disse Astatúrov, zangado, recolhendo da mesa as figuras e o tabuleiro. - Eu me arranjo, sem vocês. Vou ao Comitê de Invenções.

Astatúrov bateu a porta e se foi.

— Camaradas, — disse o redator — seria bom se algum de nós visitasse o Comitê de Invenções. Talvez, no meio de invenções muito valiosas, apareçam também as engraçadas. Aí, nós podemos publicar na revista um conto sobre um desses inventores engraçados, como o inventor Astatúrov. Quem quer ir?

$-\mathrm{Eu},-$ disse eu.

— Então, vá o mais depressa possível, agora mesmo — gritou o redator. — A propósito, informe-se sobre invenções, em geral. 
Eu cheguei ao Comitê de Invenções, do Vesenkha ${ }^{29}$. Levaram-me até o funcionário da seção de patentes.

— O que deseja? — perguntou o funcionário.

— Eu queria saber, o que é preciso para um inventor fazer invenções importantes e úteis - disse eu.

- Antes de mais nada, — disse o funcionário — vamos decidir o que devemos considerar como invenção importante e útil — com estas palavras, ele remexeu numa pilha de papéis, as quais estavam por toda a sala, tirou dois papeizinhos e disse:

— Eu vou ler para você dois pedidos para invenções apresentados por dois inventores. Escute e diga, qual destas invenções é mais importante e útil, para nós.

Eu sentei e preparei-me para escutar.

— Aqui está, — disse o funcionário - primeira invenção: inventor Liámzin. A invenção se chama "Termosol”*. A invenção consiste no seguinte: “duas bolas de vidro, uma dentro da outra, instaladas no alto de um mastro. $\mathrm{O}$ dispositivo fornece para todo o mundo uma luz que cega, da qual só é possível se esconder com uma cortina grossa". Agora escute a segunda invenção. Inventor Serebriákov. Ele inventou um meio de produção de papelão a partir de restos de papel, serragem, casca de árvore e musgo.

— Com certeza, — disse eu —o "Termosol” é mais útil e importante.

— Você está enganado, — disse o funcionário — a invenção de Serebriakov é mais importante e útil, para nós, do que a o "Termosol".

— Por que? - surpreendi-me.

\footnotetext{
${ }^{29}$ Supremo Conselho de Economia Nacional na URSS — VSNKh (BCHX, em russo) — inspecionava empresas recém-estatizadas. Normalmente referiam-se ao órgão através do acrônimo Vesenkha. Grande parte das instituições soviéticas deram origem a novas palavras a partir de suas siglas.

* Todas as invenções indicadas foram, de fato, entregues ao Comitê de Inventores, junto ao SCE. E o pedido para o "Termosol" é 2767. (NOTA DO AUTOR)
} 
— Muito simples, — respondeu o funcionário. — pode até ser que o "Termosol” seja um excelente negócio, mas, em primeiro lugar, não é factível, uma vez que não pode de modo algum ser comprovado cientificamente; em segundo, hoje em dia não precisamos absolutamente dele, ao passo que, se aplicada a toda a indústria de papel, a fabricação de papelão de resíduos representaria uma economia de 23 milhões de rublos por ano ou a válvula para locomotiva, criada por Timofiêiev, que parece ser uma invenção insignificante, se fosse fabricada representaria uma economia de cinco milhões de rublos por anos.

- Mas, então, do que um inventor precisa — disse eu - para criar invenções úteis e necessárias?

— Em primeiro lugar — disse o funcionário da seção de patentes — um inventor precisa estudar muito. Vemos, com frequência, que inventores querem resolver problemas grandes, sem o devido preparo científico para isso. Em segundo - continuou o funcionário - o inventor precisa saber de tudo que já foi feito em sua área previamente, senão ele pode estar bem uns cinquenta anos atrasado em sua invenção.

Um inventor criou fósforos que podem ser acesos nas duas pontas. Ele tinha um objetivo: a economia de madeira. Mas seus esforços foram em vão.

— Por que? - perguntei.

— Porque esses fósforos já tinham sido inventados na Alemanha há vinte anos. — respondeu o funcionário. - Em terceiro lugar, qualquer invenção tem que ser econômica. Um homem inventou um método mecânico de afiar serras. Método complexo e caro. E para quê? Afiar serras com a mão é mais simples, cômodo e barato. Enfim, qualquer invenção tem que ser sensata. Recebemos a cada ano mais de vinte mil pedidos de patentes para invenções. Dentre invenções muito valiosas e úteis há muitas absurdas e sem nexo. 
— É justamente sobre este segundo caso que eu quero consultá-lo — disse eu ao funcionário da seção de patentes.

— Sobre isso eu posso lhe dizer alguma coisa, — disso o funcionário — ouviu falar de um tal Miaskóvski?

— Não, — disse eu — não ouvi.

— Um homem notável esse Miaskóvski — disse o funcionário — recebemos dele muitas invenções, a maioria inúteis e sem nexo. Olha só uma delas.

O funcionário vasculhou nas pastas, encontrou um papelzinho e leu:

"Sombrinhas para trabalhadores do campo. É feito assim: estende-se um tecido sobre vigas de madeira. As vigas são instaladas sobre rodas. Você está trabalhando no campo e à medida em que o trabalho se desloca de lugar, você move junto sua própria tenda."

— Mas qual a utilidade disso? — perguntei.

— Aí é que está, nenhuma. — disse o funcionário. - Veja só, outra invenção dessas, do mesmo inventor: "Método de corte de roupas. $\mathrm{O}$ animal (o inventor, pelo visto, refere-se à pele de um animal morto) é cortado em duas partes. Corta-se o pescoço e o rabo, assim, obtêm-se dois paletós. Um deles com gola alta". Dispensam-se alfaiates. — disse o funcionário - E veja aqui, um novo método de auto aquecimento.

— E como seria esse tal método? — perguntei.

—É um método simples, — respondeu o funcionário — mais simples impossível. Ele pegou outro papelzinho e leu: "Método de auto aquecimento: respire embaixo do seu cobertor e o calor que sai pela boca vai envolver o corpo. Quanto ao cobertor, ele deve ser costurado na forma de um saco".

Eu desatei a rir. 
— Isso não é nada, — disse sorrindo o funcionário — um homem acabou de nos trazer um método para tingir cavalos.

— Mas para quê pintá-los? — perguntei.

—É evidente que não há motivo, — respondeu o funcionário — mas escute só o método de tintura: "para tingir um cavalo de outra cor basta amarrar suas patas dianteiras e traseiras, daí mergulhá-lo em um tanque com leite fervido".

Eu morri de rir.

— Espere, — gritou o funcionário — leia só este anúncio de um jornal americano. Ele foi republicado na revista soviética $O$ inventor.

Eu peguei a revista e li o seguinte: "Novo! Extraordinário! Indispensável a todos e a cada um! Aparelho acoplado à cabeça com ajuda do qual o chapéu é movido automaticamente. Basta uma leve inclinação de cabeça para que o chapéu se levante num gesto de saudação. Indispensável quando ambas as mãos estão ocupadas com malas”.

Nem bem consegui chegar ao final da leitura, um homem irrompeu na sala.

— Estou aqui de novo - gritou ele para o funcionário da seção de patentes.

$\mathrm{O}$ rosto do funcionário exprimiu espanto. Olhei para trás e avistei um homem de gorro de pele, botas de feltro e uma pasta enorme debaixo do braço. Eu o reconheci no ato, era Astatúrov. Mas ele, sem ter me notado, correu até a mesa, colocou a pasta e gritou:

— Eu inventei um novo jogo para crianças chamado "Um atrás do outro". Quero patenteá-lo. Vou mostrá-lo agora mesmo para o senhor.

— Isso não é necessário — disse o funcionário — o senhor apresenta um pedido de patente e escreve uma explicação.

Mas Astatúrov não escutava o funcionário, ele já havia até colocado as figuras nos lugares e começava a explicação: 
- A primeira peça representa uma vaca e se chama "vaca"; a segunda, o samovar e se chama "samovar"; a terceira, uma locomotiva e se chama "locomotiva"; a quarta, uma pessoa e se chama "médico".

- Muito bem, - disse o funcionário - mas o senhor tem que entregar a declaração por escrito.

Astatúrov continuava.

— Os jogadores começam a jogar: o primeiro jogador move a vaca amarela, o segundo move a azul; o primeiro, o samovar amarelo; o segundo, o samovar azul... pouco a pouco as figuras vão ao encontro umas das outras e, por fim, trocam de lugares...

— Certo, então, o senhor tem que apresentar a solicitação. — o funcionário da seção de patentes interrompeu Astatúrov.

— Escute mais — gritou Astatúrov — depois de trocar de lugar, as figuras seguem de volta nesta mesma ordem.

— Mas e daí? — perguntou o funcionário.

— É tudo. — disse Astatúrov solenemente.

— Mas que tipo de jogo é esse? — perguntou o funcionário da seção de patentes. Daí eu não me segurei e desatei a rir.

— Podem rir, — gritou Astatúrov — eu me arranjo sem vocês.

Agarrou seu gorro e saiu correndo da sala. Corri atrás dele. Astatúrov percorreu umas duas, três ruas e vi que ele entrou numa grande loja de jogos infantis.

Eu permaneci um pouco na rua, mas depois não aguentei e espiei dentro da loja.

Em pé, diante do balcão Astatúrov dizia:

- A terceira figura é uma locomotiva e chama-se "locomotiva", a quarta é uma pessoa e chama-se "médico".

B. Levin e D. Kharms 
Era verão. O sol brilhava. Fazia muito calor. No jardim havia uma rede pendurada. E na rede estava sentado um pequeno garoto chamado Platon.

Platon, sentado na rede, balançava-se e apertava os olhos para o sol.

De repente, alguma coisa apareceu de trás de um arbusto de lilás e tornou a desaparecer.

Platon quis saltar e ver o que era aquilo, mas estava difícil sair da rede. A rede balançava e fazia um rangido agradável, ao redor voavam borboletas e zumbiam abelhas, dava para escutar o modo como o Primus ${ }^{30}$ ruidava dentro de casa e Platon continuou deitado na rede a se balançar.

Novamente, algo tornou a aparecer e desaparecer, de trás do arbusto de lilás.

— Deve ser nossa gata Genka — pensou Platon.

De fato, um gato saiu de trás do arbusto, mas só que não era a Genka. Genka era cinza com manchas brancas, esse era todo cinza, sem manchas.

— Desde quando temos um gato assim? — pensou Platon. E, de repente, percebeu que esse gato estava de óculos. Como se isso não bastasse, na boca ele tinha um cachimbinho e estava fumando.

Platon, de olhos arregalados, olhava para o gato. E o gato, tendo visto Platon, aproximou-se dele, tirou da boca o cachimbinho e disse:

— Perdoe-me o incômodo! O senhor sabe onde mora o Platon?

- Sou eu - disse Platon.

\footnotetext{
${ }^{30}$ Fogareiro comum e geralmente a querosene, utilizado na URSS até meados dos anos 1940.
} 
— Ah, então é o senhor? — disse o gato. — Nesse caso, venha comigo para trás desse arbusto, lá alguém espera pelo senhor.

Platon desceu da rede e seguiu o gato.

Atrás do arbusto, apoiada num dos pés, havia uma garça.

Ao ver Platon, ela bateu as asas, sacudiu a cabeça e estalou o bico:

— Bom dia! — disse a garça, estendendo o pé a Platon.

Platon quis apertar o pé dela e, para isso, estendeu-lhe a mão.

— Não ouse fazer isso! — disse o gato. — Apertos de mão estão abolidos! Se quiser cumprimentar, cumprimente com os pés!

Platon esticou o pé encostando-o no pé da garça.

— Pronto, os senhores já se cumprimentaram! — disse o gato.

— Entrão vramos vroar! — disse a garça.

— Sim, então vamos voar! — disse o gato montando nas costas da garça.

— Voar para onde? - perguntou Platon. Mas a garça já o agarrava com o bico pelos colarinhos e começava a levantar voo.

— Solte-me! — gritou Platon.

— O senhor está falando uma grande asneira! — disse o gato, montado nas costas da garça. — Se nós lhe soltarmos, você cairá e se espatifará.

Platon olhou para baixo e viu o telhado de sua casa.

— Estamos voando para onde? — perguntou Platon.

— Para lá — disse o gato e acenou com suas patinhas para lados diferentes. 
Platon olhou para baixo e viu jardins, ruas e pequenas casinhas.

Na praça havia algumas pessoas que, fazendo com as mãos sombra para os olhos, olhavam para cima.

— Socorro! — pôs-se a gritar Platon.

— Crale-se! — gritou a garça, abrindo bem o bico.

Platon sentiu como se algo lhe apertasse o peito, o vento começou a assobiar forte nos ouvidos e a praça com pessoas pequenas começou rapidamente a aumentar.

— Ele está caindo! Pegue! — ouviu Platon do gato em cima. 
Uma vez perguntaram-me como funciona o automóvel.

— Não sei — respondi eu.

— Não, mesmo assim, conte como ele funciona — insistiram.

— Não sei — disse eu — e basta.

E, de fato, eu nem imagino como é que funciona um automóvel.

Ainda assim, não deixaram-me em paz.

Certa vez, eu passeava pelo Jardim de Verão. ${ }^{31}$

De repente, aproximou-se de mim um menino e disse:

— Titio, venha aqui, eu vou lhe mostrar uma coisa.

Eu fui atrás do menino. E o menino levou-me até um banquinho no qual estavam sentados quatro rapazotes vigorosos. Um deles mostrou-me o punho e disse:

— Então, conte como funciona o automóvel. Se não, olha aqui ó!

Mas eu dei no pé.

À noite, eu estava preparando-me para dormir. Dirigi-me à cama e, de repente, vi que embaixo do cobertor já havia alguém deitado. Eu quis dar um grito, mas para fora do cobertor pulou um homem de paletó marrom e com uma papirosca ${ }^{32}$ apertada nos dentes.

— Eu ser um encanador! - gritou esse homem - Conte como funciona o automóvel!

Mas eu dei no pé e escondi-me debaixo da mesa da cozinha.

No dia seguinte, tudo estava tranquilo.

Mas no primeiro dia de março, lembro-me como se fosse hoje, peguei a bacia. E a minha bacia, é preciso dizer, era pequena, de ferro e para despejar sua água, bastava virá-la.

\footnotetext{
${ }^{31}$ Construído no séc. XVIII pelo tzar Pedro, o Grande; atualmente transformado num parque aberto à visitação.

${ }^{32}$ Espécie de cigarro.
} 
Pois bem, tomei banho na bacia e entornei-a para despejar sua água. Mas, de repente, dela caiu um homem.

De susto, por pouco não engulo o sabonete.

— Quem é você? — perguntei eu com voz trêmula.

— Sou o linotipista — disse o homem. — Não se pode jogar fora o linotipista com a água do banho. Mas tudo isso não tem a ver com nosso assunto. Eu desejo saber como funciona o automóvel.

Com estas palavras o linotipista agarrou-me pelo colarinho.

— Veja bem, — disse eu — um automóvel funciona de forma a se movimentar com ajuda do motor.

— Sei — disse o linotipista. — E o que mais?

- As principais partes do motor, em essência, são: o carburador, os cilindros, o magneto e o virabrequin.

— Não entendi nada — disse o linotipista.

— E que culpa tenho eu? — disse eu.

O linotipista tirou do bolso um pedaço de papel e um lápis.

— Tome — disse ele. — Desenhe para eu ver como é.

— Hm — disse eu, e desenhei.

— Aqui está, — disse eu — o cilindro é fechado de todos os lados, mas em cima dele há um tubinho pelo qual a mistura entra.

— E por que ela entra lá? — perguntou o linotipista.

— É porque ela é puxada ou, como dizem, chupada para dentro.

No cilindro há um pistão, assim como numa bomba de sucção. É isso. Se o pistão é puxado para baixo, então o pistão chupará a mistura do tubinho.

— E por que? - perguntou o linotipista. 
- Aí, meu velho, você precisa se informar sobre o funcionamento de uma bomba de sucção, daí você vai entender.

— Está bem, está bem, estou entendendo — disse o linotipista. — E o que mais?

— E depois quando o pistão chega até bem no fundo, o tubo se fecha em cima. Então, o que nós temos? O pistão está embaixo, o tubinho, pelo qual entrou a mistura, fechado e o cilindro cheio da mistura. Aí está.

- Agora vamos empurrar o pistão para cima. O pistão começa a empurrar a mistura de volta. Mas o tubinho está fechado e a mistura não tem por onde sair. A mistura acaba espremida. E então o pistão vai se erguendo para cima e espremendo a mistura. Quando o pistão chega até quase o topo e aperta a mistura, ela explode.

— E por que? — perguntou o linotipista.

—É porque ela foi incendiada com uma faísca elétrica. O fato é que na tampa do cilindro está colocada uma rolha de porcelana pela qual passa um fio elétrico e as pontas do fio sobressaem no cilindro. Se uma corrente elétrica passar pelo fio, uma faísca pulará entre as extremidades do fio no cilindro. É essa a faísca que explodirá a mistura. A rolha de porcelana chama-se vela e ela fica no cilindro desta forma.

O linotipista olhou para o desenho.

— Estou entendendo — disse ele. — Prossiga.

— Depois, — disse eu — vem o seguinte.

— A mistura explode. Ela fica com pouco espaço. Ela quer romper o cilindro. Mas as paredes do cilindro são muito resistentes e não se rompem, só o pistão desce. Sobra mais espaço para a mistura. Agora, quando o pistão está novamente embaixo, na tampa do cilindro outro tubinho se abre. Se, nesse momento, o pistão for empurrado para cima ele expulsará toda a mistura para esse segundo tubinho.

Olhe aqui o desenho do cilindro. 
— Isso não é um cilindro, é um quadrado — disse o linotipista.

- Pfft — cuspi eu.

— E você pare de cuspir — observou o linotipista.

— Que diabos! — disse eu. — Isso não é um quadrado, é o desenho do cilindro. Olhe, eu desenho para você.

— Ora, esse é o carburador, — disse eu — aqui a gasolina e o ar são misturados.

— E para quê? — perguntou o linotipista, franzindo o cenho.

— Bem, como posso explicar-lhe — disse eu. — O motor do automóvel funciona à medida que a gasolina é queimada.

—É mesmo? - disse sombriamente o linotipista.

— É isso mesmo: para que a gasolina queime melhor ela é misturada com ar. Como você deve saber, nada pega fogo sem o ar e, para queimar melhor, é preciso um pouco de ar.

— Ah, entendi — disse o linotipista acendendo o cachimbo.

— Pois então, o carburador é feito justamente para misturar a gasolina com o ar. — disse eu.

— E como se faz isso? - perguntou o linotipista.

—É assim: de um primeiro recipiente, a gasolina passa por um tubinho fino para um segundo recipiente aberto em baixo. Aí, a gasolina espirra para cima como uma fonte e escorre pelo tubo para os cilindros.

Mas como o segundo recipiente é aberto embaixo, a gasolina vem junto com o ar e, à medida que segue pelo cilindro, mistura-se com ele. E aquilo que cai nos cilindros não se chama gasolina, mas "mistura".

— Ah, entendi, — disse o linotipista — mas que cilindros são esses? 
— Os cilindros — disse eu — são recipientes com paredes grossas, neles a mistura se queima rápido, ou melhor, não queima, explode.

(1930) 
Em cada escola dos Estados Unidos há um cartaz pendurado:

$$
\begin{gathered}
\text { Todo garoto e toda garota deve } \\
\text { comer mingau de aveia. }
\end{gathered}
$$

— Eu não quero mingau de aveia. — disse Tom Plampkin.

— Ele é nojento! — disse Devi Tchik.

— E fedorento! — disse Tom Plampkin.

— E estala na boca. — disse Devi Tchik.

Tom Plampkin puxou do bolso um pedacinho de papel, dobrou-o em forma de cone, colocou lá dentro o mingau de aveia do prato e escondeu o cone de volta no bolso.

Devi Tchik tirou do bolso um potinho metálico de pó dentifrício e, também tendo empurrado lá para dentro seu mingau, escondeu o potinho no bolso. 


\section{O Professor Trúbotchkin ${ }^{33}$}

\section{$<1>$}

Na redação da revista Tchij entrou um homem de baixa estatura, barba preta desgrenhada, vestindo uma capa preta comprida e um chapéu preto de abas largas. Debaixo de um dos braços, esse homem trazia um enorme envelope com um carimbo verde impresso.

— Eu sou o iminente Professor Trúbotchkin — disse com voz fininha esse homem estranho.

— Ah, é você que é o Professor Trúbotchkin! — disse o redator. — Nós o esperávamos há tempos. Os leitores de nossa revista nos enviam diversas perguntas. Assim, nos dirigimos ao senhor, porque só você pode responder qualquer pergunta. Ouvimos dizer que você sabe tudo.

— Sim, eu sei tudo — disse o Professor Trúbotchkin. — Eu sei pilotar aeroplano, dirigir bonde e submarino. Eu sei falar em russo, em alemão, em turco, em samoiedo ${ }^{34}$ e em fistolskiano ${ }^{35}$. Eu sei escrever poesias, ler um livro segurando-o de ponta-cabeça, ficar em uma perna só, fazer truques e até voar.

— Bom, isso já é impossível — disse o redator.

—É possível, sim — disse o Professor Trúbotchkin.

— Então mostre, voe - disse o redator.

— Pois não — disse o Professor Trúbotchkin e subiu desajeitado na mesa.

O Professor Trúbotchkin tomou impulso em cima da mesa, virou um tinteiro e uma lata de cola, derrubou alguns livros no chão, rasgou o manuscrito de alguém e saltou

\footnotetext{
${ }^{33}$ Em russo, a palavra professor (npoфeccop) é usada para designar catedráticos. O nome da personagem, Trúbotchkin, deriva do substantivo труба (tubo) e do adjetivo трувочныцй (tubular).

${ }^{34}$ Subfamília linguística constituída das várias línguas da família uraliana faladas pelo povo samoiedo. (Definição encontrada no dicionário Houaiss).

${ }^{35}$ Criação de Kharms.
} 
no ar. A capa do Professor se abriu sobre a cabeça do redator e farfalhou no ar, ao passo que o Professor agitou as mãos e caiu com estrondo no chão. Todos correram até o Professor, mas ele levantou-se de um salto e disse:

— Eu faço tudo muito rápido. Eu posso somar dois números de qualquer grandeza, de uma vez.

— Então, mostre, — perguntou o redator — quanto é três mais cinco?

— Quatro — respondeu o Professor.

— Não, — disse o redator — você está errado.

— Ah, sim — disse o Professor — dezenove!

— Também não, — disse o redator — você está errado de novo. Na minha conta dá oito.

— O Professor Trúbotchkin alisou sua barba, colocou o envelope com selo verde na mesa e disse:

— Querem que eu escreva para vocês alguns versos muito bons?

— Está bem — disse o redator.

O Professor Trúbotchkin correu até a mesa, agarrou um lápis e começou a escrever rapidíssimo. A mão direita dele começou a ficar embaçada e sumiu.

— Pronto — disse o Professor Trúbotchkin, estendendo ao redator uma folha toda preenchida com letrinhas.

— Para onde foi sua mão enquanto você escrevia? — perguntou o redator.

— Ha, ha, ha! - gargalhou o Professor. — É que quando eu estava escrevendo, eu movimentava a mão tão rápido que não dava mais para ver.

O redator pegou o papel e começou a ler os versos:

Jik, jik, jik

Foc, foc, foc,

Ric, ric, ric,

Chuk, chuk, chuk. 
— O que é isso? — gritou o redator. — Não entendi nada!

— Está em fistolskiano — disse o Professor Trúbotchkin.

— Isso é uma língua? — perguntou o redator.

— É sim, os fistolsnianos falam nessa língua — disse o Professor Trúbotchkin.

— E onde vivem os fistolsnianos? — perguntou o redator.

— Em Fistólia — disse o Professor.

— E onde é que fica Fistólia — perguntou o redator.

— Fistólia fica em Kompótia — disse o Professor.

— E onde fica Kompótia? — perguntou o redator.

— Em Tchutchêtchia — disse o Professor.

— E a Tchutchêtchia? -

— Em Bambâmbia.

— E a Bambâmbia?

— Em Tilipampâmpia.

— Desculpe-me, Professor Trúbotchkin, o que há com você? — disse, de repente, o redator esbugalhando os olhos - O que aconteceu com sua barba?

A barba do Professor jazia em cima da mesa.

—Ai! — gritou o Professor, agarrou a barba e saiu correndo.

— Pare! - gritou o redator.

— Peguem o Professor! — gritou o ilustrador Tútin.

— Pega! Pega! Pega ele! — puseram-se todos a gritar, correndo atrás do Professor. Mas ele sumiu sem deixar rastro.

No corredor ficou a capa do Professor, no patamar da escada, o chapéu e, nos degraus, a barba. Mas o professor mesmo, não se encontrava em canto algum. Apenas um 
menino de jaqueta cinza descia escada abaixo. $\mathrm{O}$ redator e o ilustrador voltaram para a editora:

— Olhe, ficou o envelope! — gritou o escritor Kolpakov.

Em cima da mesa jazia o envelope com um carimbo verde impresso. No envelope estava escrito: "Para a redação da revista 'Tchi'j." O redator apanhou o envelope, abriuo, tirou dele uma folha e leu:

“Saudações, redação da revista 'Tchij'. Acabei de voltar de uma viagem ao redor do mundo. Descansarei da viagem e amanhã vou lhes visitar. Eu sei de tudo e darei respostas a todas as perguntas de seus leitores. Envio-lhes meu retrato. Publiquem-no na capa da revista 'Tchij', número 7. Quem vai entregar esta carta para vocês é Fédia Kótchkin ${ }^{36}$.

Seu Professor Trúbotchkin”.

— Quem é esse Fédia Kótchkin? — perguntou o escritor Kolpakov.

— Não sei — disse o redator.

— E quem é esse que esteve aqui dizendo ser o Professor Trúbotchkin? perguntou o ilustrador Tútin.

— Não sei, não sei — disse o redator. — Esperemos até amanhã, quando vem o verdadeiro Professor Trúbotchkin, ele mesmo explicará tudo, agora eu não estou entendendo nada.

\section{$<2>$}

O escritor Kolpakov, o ilustrador Tútin e o redator de Tchij estavam reunidos na redação à espera do iminente Professor Trúbotchkin que, decididamente, sabia de tudo. O professor prometeu chegar as doze horas em ponto, mas o relógio já bateu duas horas e ainda nada do professor. As duas e meia, o telefone tocou na redação.

\footnotetext{
${ }^{36}$ Referente à “кочка” (kótchka), que significa montículo.
} 
— Ba- ba- ba- ba- ba! — do telefone saiam sons assustadores, parecidos com tiros de canhão.

O redator deu um grito, soltou o fone das mãos e apertou a orelha.

- O que aconteceu? - gritaram o escritor Kolpakov e o ilustrador Tútin, correndo até o redator.

— Fiquei surdo. — disse o redator limpando a orelha com os dedos e balançando a cabeça.

— Bu- bu- bu- bu- bu! — saia do fone.

— E isso o que será? — perguntou o ilustrador Tútin.

— Sabe-se lá o que é isso — gritou o redator, continuando a sacudir a cabeça.

— Tenho a impressão de estar ouvindo palavras — disse o escritor Kolpakov.

Todos se calaram e puseram-se a escuta.

— Bu-bu-bu... budu ${ }^{37} \ldots$ bu-bu... mais... ma $^{38} \ldots$ bali balu ${ }^{39} \ldots$ tu-bu-bu! — saía do fone.

— É alguém que está a falar com essa voz assustadora de baixo! — gritou o ilustrador Tútin.

O redator fez concha com as mãos, levou-as ao fone e gritou:

— Alô! Alô! Quem fala?

- O Gigante Bobov ${ }^{40}$ - bov- bov- bov! - ouviu-se do fone.

— O que? - surpreendeu-se o redator. — Mas gigantes não existem.

— Não existem, mas eu sou o Gigante Bobov!!! — o fone respondeu com um estrondo.

\footnotetext{
${ }^{37}$ Будy (budu), futuro do verbo бblmь (ser, existir, estar etc).

${ }^{38}$ Боль (bol) em russo significa "dor". No contexto da narrativa também remete à primeira sílaba de больше (bolshe), "mais"; como se a palavra tivesse sido pronunciada pela metade.

${ }^{39}$ Баль балу (bali balu).

${ }^{40}$ Genitivo plural de боб (bob), fava.
} 
— E o que você quer com a gente? - perguntou o redator.

— Vocês estão à espera do Professor Trúbotchkinnnnnnnn? — perguntou a voz do fone.

— Sim, sim, sim! — ficou feliz o redator — Onde ele está?

— Khra- khra- khra- khra- khra! — pôs-se a gargalhar o fone, com tal estrondo, que o redator, o escritor Kolpakov e o ilustrador Tútin tiveram que tapar os ouvidos.

- Fui eu! Fui eu! - khra! - khra! - khra! que sequestrei o Professor Trrrrúbotchikin. E não o deixarei ir até vocês- eis- eis- eis!! - gritou do fone a voz estranha.

— Professorrrr Trrrrrúbotchikin é meu médico ${ }^{41}$ ico-ico-ico, rik erik kikirik... — estalou algo no fone e, de repente, ficou mudo. Do fone saiu uma fumaça.

— Esse gigante terrível gritou tão alto que parece ter quebrado o telefone — disse o redator.

— Mas o que houve com o professor? - perguntou o escritor Kolpakov.

— É preciso salvar o professor! — gritou o redator — Vamos a casa dele para ajudá-lo agora mesmo!

— Mas onde? — perguntou o ilustrador Tútin — Nós nem sabemos onde mora esse Gigante Bobov.

— O que vamos fazer? - perguntou o escritor Kolpakov.

De repente, o telefone tocou de novo.

— O telefone não está quebrado! — gritou o redator e correu para atendê-lo.

O redator pegou o fone e, de repente, colocou-o no gancho de novo. Depois pegou o fone, de novo, e gritou nele:

\footnotetext{
${ }^{41} \mathrm{O}$ cotejo entre duas edições diferentes deste texto - ambas com publicações recentes da obra kharmisiana - revelou-nos que, provavelmente, a censura tenha obrigado o autor a optar pela palavra вpaч (vratch) que significa médico, ao invés de враг (vrak), inimigo. Visto que uma das edições apresenta esta última variante.
} 
— Alô! Pois não? — e deu um pulo de uns cinco passos para longe do fone.

No fone ouviam-se estalos bem fracos. O redator aproximou-se mais uma pouco e levou o fone ao ouvido.

— Aqui quem fala é Fédia Kótchkin — ouviu-se do fone.

— Sim, sim, estou ouvindo! — gritou o redator.

- O Professor Trúbotchkin foi pego pelo Gigante Bobov. Estou correndo para salvar o Professor Trúbotchkin. Aguardem meu telefonema. Até mais. - e o redator escutou Fédia Kótchkin desligar o telefone.

— Fédia Kótchkin está indo salvar o Professor Trúbotchkin. — disse o redator.

— E nós, então, o que faremos? — perguntou o escritor Kolpakov.

— Por enquanto, só nos resta esperar.

\section{$<3>$}

\section{Carta secreta}

Eu, escritor Kolpakov, acabo de receber um telegrama de Fédia Kótchkin. Fédia informa que encontrou o Professor Trúbotchkin e o Gigante Bobov e que, depois de amanhã, serão trazidos à redação. Eu contei somente ao ilustrador Tútin. Além dele, ninguém mais sabe de nada sobre isso. Vocês, criançada, também guardem segredo, não contem a ninguém que logo o Professor Trúbotchkin virá à redação. Imaginem só a surpresa de todo mundo. Eu vou lhes contar no número doze da revista Tchij como tudo aconteceu.

Escritor Kolpakov. 
O redator apanhou da mesa o primeiro envelope que lhe caiu nas mãos, tirou de dentro dele um papelzinho e leu em voz alta: "Caro Professor Trúbotchkin! Eu e meu amigo Micha Barankin ${ }^{43}$ nadamos ontem no rio e, de repente, vimos debaixo d'água uma galinha viva. O que poderia ser uma coisa dessa?"

— E então? - disse o redator. — Você consegue responder a essa pergunta?

— Quem sabe não fosse realmente uma galinha? — disse o escritor Kolpakov.

O redator brandiu a mão.

— Não, vamos ver outra pergunta. - disse o redator.

O ilustrador Tútin abriu outro envelope e leu: “Camarada Professor Trúbotchkin!

Quantas bexigas vermelhas e azuis são necessárias para me levantarem no ar? Jênia Perov ${ }^{44}$ ".

— E então, — disse o redator — quem consegue responder a essa pergunta? Eu pessoalmente não posso.

— Eu também não — disse o escritor Kolpakov.

— Eu também não posso — disse o ilustrador Tútin.

— Então, o que faremos sem o Professor Trúbotchkin?

Entrou na editora o carteiro e trouxe mais um maço de envelopes.

— Para o Professor Trúbotchkin! — disse o carteiro e foi embora. >

\footnotetext{
${ }^{42}$ A série de histórias do Professor Trúbotchkin foram publicadas nas revistas Tchij números 7, 8, 11 e 12, em 1933, conforme nota do editor da coletânea Даниил Хармс. Собрание сочинений в трёх томах. (Sobranie sotchinenie v triox tomakh) Санкт-Петербург. Азбука. 2011. As sequências III e IV que agora sucedem constam na supracitada edição como trechos não publicados à época. Entretanto, optamos por incluir na tradução estes dois excertos visto que foram publicados em 1994 na edição Даниил Хармс. (Daniil Kharms) Москва. Виктория. 1994.

${ }^{43}$ Referente à баранка (baranka), rosquinha de trigo, volante.

${ }^{44}$ Genitivo plural de nepo (peró), pluma.
} 


\section{$<$ IV}

O Professor Trúbotchkin estava deitado no chão, com as mãos e as pernas atadas por uma corda grossa. Ao lado, no banquinho, estava sentado um homem muito gordo fumando cachimbo. Este era o Gigante Bobov. Gigantes não existem, existem apenas pessoas muito altas. Mas Bobov nem era uma pessoa muito alta. Foi ele mesmo que se chamou de gigante.

— Você, Professor Trúbotchkin, sabe tudo — dizia o Gigante Bobov. — Já eu não sei nada. Por que isso acontece?

— Porque você é um preguiçoso. É por isso que você não sabe nada — disse o Professor Trúbotchkin. - Já eu sei muito porque passo o tempo inteiro estudando alguma coisa. Mesmo nesse momento, estou deitado amarrado, conversando com você, mas em minha cabeça estou revisando a tabuada.

- Ah, essa tabuada! - disse o Gigante Bobov. - Por mais que eu estudasse, nem assim consegui aprender nada. Um vezes um é igual a quatro! Isso eu ainda lembro, mas de resto não sobrou nada na cabeça!

—É, a ciência não é fácil...>

Na redação da revista Tchij reinava uma terrível desordem. Em cima das mesas, das cadeiras, no chão e no peitoril das janelas havia montes de cartas com perguntas ao Professor Trúbotchkin. O redator estava sentado em uma pilha de cartas, comia pãozinho com manteiga e pensava em como responder à pergunta: "Por que o crocodilo é mais baixo que o hipopótamo?" De repente, no corredor ouviu-se um barulho, um tropel, a porta foi escancarada e na redação entraram correndo o escritor Kolpakov e o ilustrador Tútin. 
— Hurra! Hurra! ${ }^{45}$ — gritou o pinto Tútin.

- O que aconteceu?

Nisso a porta tornou a se abrir e na redação entrou um menino de jaqueta cinza.

— E quem é esse aí? — admirou-se o redator.

— Hurra- a! - gritaram Kolpakov e Tútin.

Gente de toda a editora juntou-se ao barulho da redação de Tchij. Vieram: o encanador Kuzmá, o tipógrafo Petrov, o encadernador Rindakóv, a faxineira Filimónova, o ascensorista Nikolai Andréitch, a datilógrafa Natália Ivánovna.

- O que aconteceu? - gritaram eles.

— Mas o que é isso? - gritou o redator.

- Hurra- a! — gritou o menino de jaqueta cinza.

— Hurra- a! - ecoaram o escritor Kolpakov e o ilustrador Tútin.

Ninguém conseguia entender patavina.

De repente, no corredor algo bateu umas quatro vezes, estourou que nem um tiro e um homem todo curvado, para conseguir passar pela porta, entrou na redação; tão grande ele era que, quando se endireitou, sua cabeça quase tocou no teto.

— Cheguei — disse esse homem com uma voz tão assustadora que os vidros começaram a tremer, a tampa do tinteiro pôs-se a pular e a lâmpada a balançar.

A datilógrafa Natalia Ivánovna soltou um grito, o encadernador Rindakóv escondeu-se atrás da estante, o recepcionista Nikolai Andréitch coçou a nuca, já o redator aproximou-se do enorme homem e disse:

— Quem é você?

— Quem sou eu? — reperguntou o homem enorme com voz tão alta, que o redator tapou os ouvidos e sacudiu a cabeça.

\footnotetext{
${ }^{45}$ Interjeição bastante típica na cultura russa; expressa comemoração, alegria e felicidade.
} 
— Está bem, é melhor você ficar quieto! — gritou o redator.

Nesse momento, entrou na redação um homem troncudo, de barba preta e olhos brilhantes. Vestia uma jaqueta de couro, na cabeça usava um quepe, também de couro. Ao entrar no cômodo ele tirou o quepe e disse:

- Bom dia!

— Vejam só! - gritou o tipógrafo Petrov. — O retrato dele foi publicado no número sete da Tchij.

— Esse é o Professor Trúbotchkin! — gritou a faxineira Filimónova.

— Sim, eu sou o Professor Trúbotchkin — disse o homem de jaqueta de couro — e esse é meu amigo, o Gigante Bobov; aquele menino é meu ajudante, Fédia Kótchkin.

— Hurra! - gritou, então, o redator.

— Eu estava na casa do Gigante Bobov — disse o Professor Trúbotchkin. — Ficamos dois meses seguidos debatendo uma questão científica sobre quem seria mais forte: o leão ou o tigre. Nós podíamos continuar a discutir por mais tempo ainda, mas chegou Fédia Kótchkin e nos disse que os leitores de Tchij aguardam respostas para suas perguntas.

- E esperam faz tempo - disse o redator e apontou as pilhas de postais e envelopes, pacotes grandes e bilhetinhos — Vejam só o que isso aqui virou. Tudo isso são perguntas de nossos leitores.

— Bom, mas agora responderei a todas — disse o Professor Trúbotchkin. Bobov junte, por obséquio, todos esses envelopes e papeizinhos e, por favor, leve-os até minha casa, por obséquio.

Bobov arregaçou as mangas, tirou do bolso uma corda amarrou as cartas e os pacotes em quatro pilhas enormes, jogou-as em seus ombros e saiu da redação. 
— Muito bem, — disse o Professor Trúbotchkin — ainda sobraram umas duzentas cartas. Vou respondê-las agora mesmo.

O Professor Trúbotchkin sentou-se à mesa, Fédia Kótchkin começou a abrir as cartas e colocá-las empilhadas em frente ao Professor. Fédia Kótchkin fazia isso com tanta rapidez que todos os presentes começaram a sentir tontura e saíram da redação para o corredor.

O redator foi o último a sair.

— Hurra! — disse o redator. - Agora todos os nossos leitores receberão respostas às suas perguntas.

— Não, nem todos! — disseram o escritor Kolpakov e o ilustrador Tútin.

APENAS AQUELES QUE ASSINAREM A REVISTA TCHIJ NO ANO DE 1934.

$$
* * *
$$

Nota da tradutora: O cotejo entre os textos das coletâneas fontes deste trabalho mostrou que, na publicação de 1994, a personagem do gigante Bobov figura como "inimigo" do professor - враг (vrak), em russo - e, na edição em 2011, como “médico" - вpач (vratch). Levando-se em consideração o enredo da história, supomos que, originalmente, o gigante tenha sido concebido como inimigo do professor, não médico. Tendo em vista que num dos episódios, que à época não foi publicado em Tchij, ele sequestrava o herói, Professor Trúbotchkin. Nossa hipótese é de que a mudança de denominação tenha acontecido por motivos de censura. 


\section{Kolpakov, o fanfarrão}

Era uma vez um homem chamado Fiódor Fiódorovitch Kolpakov.

— Eu — dizia Fiódor Fiódorovitch Kolpakov — não tenho medo de nada! Podem

me dar um tiro de canhão, me jogarem na água, me queimarem no fogo, não tenho medo de nada! Nem de tigres, nem de águias, nem de baleias e nem de aranhas, não tenho medo de nada!

Eis que certo dia, Fiódor Fiódorovitch Kolpakov estava parado em cima da ponte olhando mergulhadores afundarem na água. Olhava, olhava. Depois, quando os mergulhadores saíram da água e tiraram as roupas de mergulho, Fiódor Fiódorovitch não aguentou e pôs-se a gritar-lhes da ponte:

— Ei, — gritou ele — isso não é nada! Eu poderia fazer melhor! Não tenho medo de nada! Nem de tigres, nem de águias, nem de baleias e nem de aranhas, não tenho medo de nada! Podem me queimar no fogo, me darem um tiro de canhão, me jogarem na água, não tenho medo de nada!

—É mesmo? — falam os mergulhadores. — E por que não tenta entrar na água?

— Para quê? — diz Fiódor Fiódorovitch pronto para dar no pé.

— O que, irmão, ficou com medo? — perguntam-lhe os mergulhadores.

— Eu não tenho medo de nada! — diz Fiódor Fiódorovitch — Mas a troco de quê vou me meter debaixo d'água?

— Está com medo! — dizem os mergulhadores.

— Não estou, não! — diz Fiódor Fiódorovitch Kolpakov.

— Então, vista a roupa de mergulho e entre na água.

Fiódor Fiódorovitch Kolpakov entrou na água e os mergulhadores lhe gritaram lá de cima pelo telefone:

— E, aí, Fiódor Fiódorovitch? Dá muito medo? 
E Fiódor Fiódorovitch lhes respondeu lá de baixo:

— Niav... niav... $\operatorname{niav}^{46} \ldots$

— Bom, — dizem os mergulhadores — para ele já basta.

Eles retiraram Fiódor Fiódorovitch da água, tiraram dele a roupa de mergulho, enquanto Fiódor Fiódorovitch olhava ao redor com olhos apavorados e não dizia outra coisa a não ser niav... niav... niav...

— Está vendo, irmão, não se gabe em vão — disseram-lhe os mergulhadores e o acomodaram na beira.

Fiódor Fiódorovitch Kolpakov foi para casa e, desde então, nunca mais se gabou de nada.

(1934)

\footnotetext{
${ }^{46}$ Kharms cria essa onomatopeia para reproduzir o som da fala embaixo d'água.
} 


\section{Como Macha fez o burro levá-la para a cidade}

Lá vai um burro a puxar uma charrete e na charrete está Macha. O sol brilha. As maçãs crescem nas árvores.

De repente, o burro parou.

Macha disse ao burro: "Eia, por favor. Vá para a cidade". Mas o burro abana o rabo e ficou parado no lugar.

Macha mostrou ao asno o chicote e disse: "Olha só o que eu tenho aqui". Mas o burro só mexeu as orelhas e ficou parado no mesmo lugar.

Então, Macha desarreou o burro da charrete. E o arreou, de novo, só que de rabo para frente.

Daí Macha pegou uma tesoura e cortou um pedaço da crina do burro. Ele olhava para Macha surpreso.

Enquanto isso, Macha sentou-se de novo na charrete e, tendo feito uma barba e um bigode com a crina do burro, colou-os em seu rosto.

O burro arregalou os olhos e, apavorado, começou a andar para trás.

O burro andava para trás e puxava a charrete junto. E foi assim que Macha chegou à cidade.

D. Kharms

Nota da tradutora: Conto da série em quadrinhos "Умная Маша" (Macha, a inteligente) para a qual escreviam, além de Kharms, outros autores como Nina Gernet. 


\section{O ouriço valente}

No quintal havia uma caixa.

Os animais se aproximaram da caixa e começaram a examiná-la, cheirá-la e lambê-la.

E a tal caixa, de repente - um, dois, três - se abriu.

E dessa caixa - um, dois, três — saltou uma cobra.

Os animais se assustaram e saíram correndo.

Só um ouriço não se assustou, pulou sobre a cobra e - um, dois, três abocanhou-a.

E depois sentou-se em cima da caixa e pôs-se a gritar: "cucurucu!"

Não, não é assim! O ouriço pôs-se a gritar: “au-au-au”.

Não, assim também não é! O ouriço pôs-se a gritar: "miau-miau-miau”.

Não, de novo não é assim! E eu também não sei como é.

Quem aí sabe qual é o grito do ouriço?

Vânia Mokhov 


\section{O quebra-ossos}

Eu tinha um amigo que se chamava Vassili Petróvitch Ivanov. Aos dez anos já era da altura de um armário e, aos 15, tinha crescido tanto para os lados que ficou parecido com um.

Eu e ele estudávamos na mesma escola. E na escola seu apelido era Armário, de tão enorme que era. Ele tinha uma força tremenda. Todo mundo da classe partia pra cima dele e, feito cachorrinhos, ele nos jogava para todos os lados enquanto ficava no meio rindo.

Uma vez ocorreu o seguinte caso. Na escola, fizemos um espetáculo vespertino. Daí, durante o espetáculo foi preciso, sabe-se lá porquê, colocar uma cátedra no palco. Tinham que trazer lá da sala, mas como era pesada, foram chamar Vássia ${ }^{47}$ para ajudar.

Sem contar que as lâmpadas de todas as salas tinham sido tiradas para iluminar o salão e as cenas. Por isso, nas salas estava escuro.

Vássia correu até a sala para buscar a cátedra, mas na escuridão, ao invés de pegar a cátedra, pegou um fogão, arrancou-o da parede e o arrastou para o corredor. Depois tiveram que reformar essa sala e colocar um fogão novo. Olha só a força que tinha meu amigo Vássia Ivanov.

Vássia não conseguia terminar a escola. Ele não levava jeito e, por mais que estudasse, não conseguia lembrar quanto era sete vezes seis. Era ruim de memória e vagaroso de raciocínio.

Eu passei da quarta série para a quinta, mas Vássia repetiu de ano. Depois saiu da escola, de vez, e foi embora para o Japão com os pais.

Foi no Japão que aconteceu a história que quero contar.

\footnotetext{
${ }^{47}$ Hipocorístico de Vassili.
} 
Vássia chegou ao Japão com seus pais. Eles decidiram arrumar algum serviço para Vássia. Mas não aparecia emprego. A não ser de carregador, só que isso não compensava. Daí que alguém disse aos pais de Vássia: "Por que vocês não põem seu filho para lutar. Olha só como ele é forte. E os japoneses adoram lutas. Nesse ramo são grandes mestres. Então, seu filho tem que entrar numa escola de luta daqui. Bem aqui há uma escola dessas, onde o professor japonês, senhor Kurano, leciona e fala bem em russo. De modo que, ali seria muito conveniente para seu filho. Ele vai terminar e ser um grande lutador".

Os pais de Vássia ficaram felizes.

— Onde é que fica a escola? — perguntaram.

— Logo ali, naquela rua japonesa.

Então, os pais levaram Vássia à escola japonesa de luta. Um velhinho japonês, pequeno e amarelado, parecido com um cogumelo todo enrugado, saiu ao encontro deles, olhou-os e perguntou em russo:

— Vocês querem falar com quem? - perguntou.

— Nós procuramos o senhor Kurano, o professor de luta japonesa — disseram os pais de Vássia.

O velhinho japonês olhou para Vássia, esfregou as mãos e disse:

— Kurano sou eu, mestre de jiu-jitsu. E, pelo que vejo, vocês me trouxeram um aluno.

— Ah! — disseram os pais de Vássia. — Aqui está nosso filho. Ensine-lhe sua arte.

— Pois bem, - disse o velhinho japonês — pelo visto seu filho é um jovem bastante forte.

— Oh! — disseram os pais de Vássia. — É uma força que dá até medo! 
— Ora, — disse o velhinho japonês — isso ainda precisa ser visto. E se quiserem, aliás, eu posso aceitá-lo para um teste.

— Queremos muito — disseram os pais de Vássia. — Pode levar, por favor.

Então Vássia ficou para um teste com o senhor Kurano e seus pais foram para casa.

— Siga-me — disse o senhor Kurano e levou Vássia pelos cômodos internos.

Vássia seguia atrás do senhor Kurano e morria de medo de bater o ombro na parede para não quebrar a casa, de tão frágil que ela era.

Daí então, eles chegaram a uma sala coberta com tapetes de palha. As paredes também eram revestidas com os tapetes. Na sala, os alunos do senhor Kurano estavam treinando: agarravam-se uns aos outros pelos braços, se jogavam no chão, saltavam em pé de novo, jogavam uns aos outros por cima da cabeça.

O senhor Kurano esperou um pouco, observou, resmungou algo em japonês, agitou as mãos e, de novo, dirigiu-se, em russo, para Vássia:

— Enquanto meus alunos continuam a treinar, vamos nós para aquela sala à parte - disse.

Eles entraram na sala vazia, também revestida com tapetes de palha.

— Bom, — disse o senhor Kurano — você sabe o que é jiu-jitsu?

— Não, não sei — disse Vássia.

— Trata-se da nossa ciência da luta — disse o senhor Kurano. — Em russo, a palavra jiu-jitsu significa "quebra-ossos", porque nós conhecemos alguns procedimentos que, realmente, com um golpe da palma da mão podemos quebrar um fêmur. Mas não tenha medo, não vou quebrar seus ossos.

— Medo eu não tenho, mesmo — disse Vássia. — Pois sou forte. 
— Bem, - disse o senhor Kurano — se há uma coisa em que você não deve confiar totalmente é na sua força. Agora nós vamos testar como ela é. Tire sua jaqueta e arregace as mangas. Eu vou ver como são os músculos dos seus braços.

Vássia tirou a jaqueta, arregaçou as mangas e dobrou o braço. Os músculos se encheram feito balão. O japonês apalpou o braço de Vássia e balançou a cabeça.

— Olhe aqui, — disse o senhor Kurano — nós damos valor acima de tudo a este músculo aqui, que em você é bem fraco.

Com estas palavras o senhor Kurano arregaçou a manga e mostrou para Vássia seu braço magro e cheio de veias.

— Olha como vou dobrar o braço! — disse o senhor Kurano. — Está vendo uma bolinha bem aqui na lateral do cotovelo? Esse é o músculo ao qual damos valor acima de todos. E o seu é fraco. Mas não tem importância. Com o tempo o seu também vai ficar forte. Agora, pegue-me por baixo dos braços e me levante.

Vássia pegou o senhor Kurano por baixo dos braços e o levantou, tão fácil, como se fosse um samovarzinho vazio.

— Isso, — disse o senhor Kurano — agora ponha-me de volta no chão.

Vássia colocou o senhor Kurano no chão.

— Está bem, — disse o senhor Kurano — você tem certa força. Me dê um golpe.

— Hi, hi! — disse Vássia. — Como é que vou bater no senhor?

— Assim mesmo, pegue e bata! — disse o senhor Kurano.

— Não tenho coragem! — disse Vássia.

— Ah! — disse o senhor Kurano com enfado. — Que bobagem! Estou dizendo para você me dar um golpe. E então? Pode dar. 
Vássia olhou para o senhor Kurano. Era um velhote miúdo e magrelo, quase duas vezes menor do que Vássia, com carinha enrugada e olhinhos franzidos. A cabeça do senhor Kurano não era maior do que um punho de Vássia.

"E agora? - pensou Vássia. — Se eu bater, ele vai morrer aqui mesmo."

— Vamos lá, pode bater! Pode bater! — gritava o senhor Kurano.

Vássia levantou o braço e, indeciso, empurrou o ombro do senhor Kurano.

O senhor Kurano cambaleou de leve.

— Isso não é golpe! — ele gritou. — Tem que bater mais forte!

Vássia bateu, de leve, no peito do senhor Kurano.

— Mais forte! - gritou o senhor Kurano.

Vássia bateu mais forte. O senhor Kurano cambaleou, mas continuou de pé.

— Mais forte! — gritou ele.

Vássia bateu mais forte ainda. O senhor Kurano cambaleou com mais força, mas também continuou de pé.

"Que coisa!” — pensou Vássia.

— Mais forte! - gritou o senhor Kurano.

"Então, está bem" - pensou Vássia, virou-se e, com toda a força que tinha, acertou um soco no senhor Kurano. Mas o senhor Kurano já não estava mais na frente de Vássia que, sem encontrar resistência, correu alguns passos e bateu contra a parede.

— Parece uma enguia! — disse Vássia.

Mas o senhor Kurano já estava de novo diante de Vássia e, fazendo caretas, disse:

— Não se desanime, meu jovem! Bata mais uma vez, só que com mais força ainda!

“Ah, é assim!? — pensou Vássia. — Seu cogumelo, agora eu vou esmagar você!” — e decidiu bater forte, mas com cuidado e calculando para não cair. 
Vássia já estava levantando a mão para acertar o golpe e, de repente, foi como se ele próprio tivesse recebido uma descarga elétrica no flanco. Vássia soltou um grito e agarrou o senhor Kurano pelo pescoço. Mas o senhor Kurano deu um mergulho para baixo. Vássia, de repente, perdeu o equilíbrio, passou por cima do japonês e espatifou-se no chão.

— Ah! - gritou Vássia e ficou de pé. Mas, no mesmo instante, levou um golpe nas pernas e tornou a perder o equilíbrio.

O senhor Kurano agarrou Vássia pelos braços e o puxou para o lado. Vássia passou uma perna para a frente e sentiu-se, novamente, em posição de equilíbrio, mas foi só querer segurar o senhor Kurano que recebeu, de novo, um golpe no flanco e vendo-se, de repente, de ponta-cabeça, relou os pés no teto e passou por cima do japonês tornando a se espatifar no chão.

Vássia saltou, olhando assustado ao redor e, em seguida, voou em volta do japonês e foi parar deitado no chão.

Totalmente perdido, Vássia levantou-se de um salto e disparou para a porta.

- Aonde você vai? - gritou-lhe o senhor Kurano.

Mas Vássia pulou para a sala onde os alunos do senhor Kurano treinavam.

Atropelou todo mundo, saiu correndo para o corredorzinho e dali para a rua.

Vássia chegou correndo em casa, sem o casaco e com os cabelos desgrenhados.

— O que deu em você? — exclamou a mãe de Vássia.

— Cadê seu casaco? — gritou o pai de Vássia.

Vássia não gostou do Japão e voltou para Leningrado.

Agora Vassili Petróvictch Ivanov mora em Leningrado e trabalha na garagem dos ônibus. Seu trabalho consiste em arrastar ônibus quebrados de um lugar para outro. 
Ele contou a história do professor japonês de jiu-jitsu só para mim, por eu ser colega de escola, mas em geral ele não gostava de falar sobre isso para ninguém. 


\section{Um conto maravilhoso}

— Pois bem, vamos escrever um conto maravilhoso — disse Vânia ${ }^{48}$, colocando um caderno em cima da mesa.

— Vamos — disse Liénotchka ${ }^{49}$ sentando-se na cadeira.

— Vânia pegou o lápis e escreveu:

"Era uma vez um rei..."

Nisso, Vânia parou para pensar, ergueu os olhos para o teto. E Liénotchka deu uma espiada no caderno, lendo o que Vânia havia escrito.

— Já existe essa estória — disse Liénotchka.

— E como você sabe? — perguntou Vânia.

- Sei porque li — disse Liénotchka.

— Do que se trata, então? — perguntou Vânia.

— Trata-se de como o rei bebia chá com maçãs e, de repente, engasgou-se. A rainha começou a bater nas costas dele, afim de que o pedaço de maçã pulasse para fora da garganta. Mas o rei pensou que a rainha estivesse brigando e acertou a cabeça dela com o copo. Então, a rainha ficou brava e acertou o rei com um prato. E o rei acertou-a com a tigela. A rainha bateu nele com a cadeira. O rei deu um pulo e acertou a rainha com a mesa. A rainha derrubou o bufete em cima do rei. Mas o rei saiu debaixo do bufete e atirou nela a coroa. Daí a rainha puxou o rei pelos cabelos e jogou-o pela janela. Mas o ele subiu de volta ao quarto por uma outra janela, agarrou a rainha e enfiou-a dentro do fogão a lenha. Mas a rainha saiu lá no telhado pela chaminé, desceu ao jardim pelo pararaios e retornou ao quarto pela janela. Nessa hora, o rei aquecia o fogão a lenha para

\footnotetext{
${ }^{48}$ Hipocorístico de Ivan.

${ }^{49}$ Hipocorístico de Elena.
} 
queimar a rainha. A rainha aproximou-se sorrateiramente e empurrou o rei pelas costas. O rei caiu dentro do fogão e lá foi queimado.

E assim acabou-se a estória — disse Liénotchka.

— É uma estória muito boba — disse Vânia. - Eu queria escrever algo bem diferente.

— Pois, escreva — disse Liénotchka.

— Vânia pegou o lápis e escreveu:

"Era uma vez um bandoleiro..."

— Espere! — gritou Liénotchka — Essa estória já existe!

— Eu não sabia — disse Vânia.

— Será possível que você não sabe do bandoleiro? — disse Liénotchka. — Ele estava fugindo da guarda, pulou para cima de um cavalo com tanto ímpeto, que atravessou para o outro lado e caiu no chão. O bandoleiro praguejou e pulou para cima do cavalo de novo, mas errou o cálculo outra vez, cruzou para o outro lado e caiu no chão. Levantouse, brandiu o punho, foi montar no cavalo de novo, atravessou por cima do bicho e aterrissou no chão. Nisso, o bandoleiro sacou a pistola do cinturão, disparou para o alto e tornou a pular no cavalo, mas com tanta força que, novamente, atravessou por cima dele e estatelou-se no chão. Então o bandoleiro arrancou o gorro da cabeça, pisoteou-o e tornou a pular no cavalo, atravessou por cima dele outra vez, estatelou-se no chão e quebrou uma perna. O cavalo foi para o lado, o bandoleiro correu mancando até o cavalo e deu-lhe o soco na testa. O cavalo fugiu. Nesse momento os guardas chegaram, pegaram o bandoleiro e o levaram para a cadeia.

— Bom, não vou escrever sobre o bandoleiro — disse Vânia.

— E sobre quem você vai escrever? — perguntou Liénotchka.

— Vou escrever um conto sobre um ferreiro — disse Vânia. 
Vânia escreveu:

"Era uma vez um ferreiro..."

— Essa estória também já existe! — pôs-se a gritar Liénotchka.

— Mesmo? - disse Vânia e abaixou o lápis.

- Mas é claro - disse Liénotchka. - Era uma vez, um ferreiro. Certo dia, forjava ele uma ferradura e levantou o martelo com tanta força que o martelo se desprendeu do cabo, saiu voando pela janela, matou quatro pombos, acertou a torre de incêndio, desviou para o outro lado, quebrou a janela da casa do capitão do corpo de bombeiros, voou por cima da mesa, à qual estava sentado o próprio capitão com a mulher, rachou a parede na casa do capitão e saiu voando para a rua. Nisso, derrubou o poste de luz no chão, passou uma rasteira no sorveteiro e bateu na cabeça de Karl Ivánovitch Shusterling que, bem nessa hora, tinha tirado o chapéu para arejar a nuca. Depois de bater na cabeça de Karl Ivánovitch Shusterling, o martelo voou de volta e tornou a passar rasteira no sorveteiro, derrubou do telhado dois gatos que brigavam, virou uma vaca de ponta-cabeça, matou quatro pardais e entrou voando de novo na serralheria, caiu bem no cabo que o ferreiro ainda continuava a segurar com a mão direita. Tudo isso aconteceu tão rápido que o ferreiro não notou nada e continuava a forjar a ferradura.

— Bom, se já foi escrito um conto sobre o ferreiro, então vou escrever sobre mim mesmo - disse Vânia. E escreveu:

"Era uma vez um menino Vânia..."

— Sobre Vânia também já existe uma estória — disse Liénotchka. — Era uma vez o garoto Vânia e, então, um dia lá foi ele até...

— Espere, — disse Vânia — eu queria escrever uma estória sobre mim mesmo.

— Sobre você já foi escrita uma estória — disse Liénotchka.

— Não pode ser! — disse Vânia. 
— E eu lhe digo que foi escrita — disse Liénotchka.

— E foi escrita onde? — surpreendeu-se Vânia.

— Compre a revista Tchij, n. 7 e lá você vai ler uma estória sobre si mesmo disse Liénotchka.

Vânia comprou Tchij, n. 7, e daí leu esta mesma estória que você acabou de ler.

D. Kharms - Shardam 


\section{XXX}

No ano passado fui comemorar o ano novo na casa de meus amigos e amigas. Foi muito divertido.

Na festa de Iáchka joguei quadrado mágico, na festa de Churka brinquei de esconde-esconde, na festa de Ninka olhei ilustrações, na festa de Valódia dancei na roda, na festa de Lisavieta comi bombons de chocolate, na festa de Pávlucha comi maçãs e $\operatorname{peras}^{50}$.

E neste ano, irei à festa de ano novo da escola, lá vai ser mais divertido ainda.

Vânia Mokhov

(1935?)

${ }^{50}$ No texto original há rimas entre o nome do amigo e a atividade em sua casa. 


\section{Sobre o cachorro Bububu}

Era uma vez um cachorro muito inteligente. O nome dele era Bububu.

Ele era tão inteligente que sabia até desenhar.

Então, uma vez, ele desenhou um quadro. Mas ninguém conseguia entender o que estava desenhado no quadro.

O ratinho miudinho chegou correndo, olhou o quadro, cheirou a moldura e disse:

— Não, não sei o que está desenhado no quadro. Talvez seja um queijo, uí - uí uí! Talvez uma velinha, puí- puí-puí!

Veio o galo Erofei, colocou-se na ponta dos pés, olhou para o quadro e disse:

— Não, não sei o que está pintado no quadro. Talvez seja kasha ${ }^{51}, \mathrm{cu}-\mathrm{cu}-\mathrm{ru}-$ cu! Ou talvez uma tina de madeira, ca $-\mathrm{cu}-\mathrm{re}-\mathrm{cu}$ !

Chegou a patinha Aniútotchka. Olhou para o quadro de um lado e disse:

— Quá, quá, quá!

Isso é um caracolzinho,

Quá, quá, quá!

Talvez seja uma rãzinha.

Depois olhou para o quadro de outro lado e disse:

— Quá, quá, quá!

Não é uma rãzinha.

Quá, quá, quá!

É um caracolzinho!

Chegou a macaca Dona Maria Timoféievna, coçou o flanco, olhou para o quadro e disse:

\footnotetext{
${ }^{51}$ Prato de cereais cozidos muito popular na Rússia, em geral, servido com leite.
} 
- Bal - bal - bal - bal.

Bol - bol - bol - bol.

— Ei! - gritaram para a macaca. — Fale direito!

E ela de novo:

— Lok! vok! mok! roc!

Luk! lak! lik! lek!

— Ah, pare com isso! — gritaram para a macaca. — Não dá para entender o que você fala.

E a macaca coçou a nuca com o pé e foi embora.

Por último, chegou o famoso pintor Ivan Ivánitch Pniov. Passou um tempo coçando a cabeça e olhando para o quadro e, finalmente, disse:

— Não, ninguém sabe o que está desenhado no quadro e eu também não sei.

Nisso, o inteligente cachorro Bububu deu um passo à frente, deu uma olhada no próprio quadro e pôs-se a gritar:

— Ai, ai! Au, au! Mas que coisa, o quadro está virado para vocês do lado avesso. Vejam só, vocês estão olhando o lado de trás do quadro. Vejam só!

Dizendo isso o cachorro Bububu virou o quadro.

O quadro era tão bem feito que nós decidimos publicá-lo na Revista Tchij, número 1 , de 1936. 


\section{Os sete gatos}

Olha só essa história! Não sei o que fazer. Estou totalmente confuso. Não consigo entender nada. Vejam vocês mesmos, fui trabalhar de vigia numa exposição de gatos. Deram-me luvas de couro para que os gatos não me arranhassem os dedos, me mandaram colocar cada gato em uma gaiola e escrever na gaiola o nome de cada um.

— Muito bem, — disse eu — mas como se chamam esses gatos?

— Pois bem, — dizem — a gata da esquerda, se chama Machka, ao lado dela está Pronka, depois Bubéntchik ${ }^{52}$; essa é Tchurka ${ }^{53}$, essa é Murka, essa Burka ${ }^{54}$ e essa Chtukatiurka ${ }^{55}$.

Então, fiquei sozinho com os gatos e pensei: “deixa eu, primeiro, fumar um cachimbo, depois colocar esses gatos nas gaiolas".

E lá estou eu a fumar um cachimbinho e a olhar os gatos.

Um limpa o focinho com a pata, outro olha para o teto, o terceiro passeia pelo recinto, o quarto grita com voz terrível, outros dois bufam um para o outro, mas um chegou perto de mim e mordeu minha perna.

Dei um pulo e até derrubei o cachimbo.

— Ai! — gritei — gato nojento! Você nem parece gato. Você é Pronka ou Tchurka, ou quem sabe Chtukatiurka?

Nisso percebi, de repente, que tinha confundido todos os gatos. Qual é o nome de cada um eu, absolutamente, não sei.

— Ei — grito - Machka, Pronka, Bubéntchik, Tchurka, Murka, Burka, Chtukatiurka!

\footnotetext{
52 Sininho.

53 Taco de madeira.

54 Burca.

${ }^{55}$ Argamassa.
} 
Mas os gatos não me dão a menor atenção.

Eu gritei para eles:

—Quiz - quiz - quiz!

Daí todos os gatos, de uma vez, viraram suas cabeças para mim.

O que fazer?

Então, os gatos pularam no peitoril, deram-me as costas e puseram-se a olhar pela janela.

E nisso todos eles juntos sentaram-se ali, mas qual era Chtukatiurka e qual era Bubéntchik?

Eu não consigo entender nada.

Eu acho que só alguém muito inteligente vai saber adivinhar como se chama cada gato.

Olhe para esse desenho e diga: qual gato é Machka, qual é Pronka, qual é Bubéntchik, qual é Tchurka, qual é Murka e qual é Chtukatiurka? 
Volódia estava sentado à mesa desenhando.

Desenhou Volódia uma casinha, na janela da casinha desenhou uma pessoa de barba preta, ao lado da casinha desenhou uma árvore, ao longe desenhou um campo e uma floresta. Depois desenhou, perto da casinha, um arbusto e começou a pensar no que mais desenhar. Pensou, pensou e deu um bocejo. Depois bocejou outra vez e decidiu desenhar uma lebre embaixo do arbusto.

Volódia pegou o lápis e desenhou a lebre.

A lebre saiu bem bonita, com orelhas compridas e um rabinho fofo.

— Ei você aí! — pôs-se a gritar, de repente, o homem de barba preta da janela da casinha. - De onde apareceu essa lebre? Pois agora vou atirar nela com a espingarda!

A porta da casa foi aberta e o homem saiu correndo para o terracinho com a espingarda nas mãos.

— Não ouse atirar na minha lebre! — gritou Volódia.

A lebre moveu as orelhas, tremelicou o rabinho e correu saltando para a floresta.

“Bam!" - atirou com a espingarda o homem de barba preta.

A lebre pôs-se a saltar mais rápido ainda e escondeu-se na floresta.

— Errei! — gritou o homem de barba preta e jogou a espingarda no chão.

— Estou muito feliz que você tenha errado! — disse Volódia.

— Não! — pôs-se a gritar o homem de barba preta. — Eu, Karl Ivánovitch Shusterling, queria acertar a lebre e errei! Mas ei de acertá-la! Ei mesmo!

Karl Ivánovitch agarrou a espingarda e correu para a floresta. 
— Espere! — gritou Volódia.

— Não, não, não! Eu ei de acertá-la! — gritava Karl Ivánovitch.

Volódia saiu correndo atrás de Karl Ivánovitch.

— Karl Ivánovitch! Karl Ivánovitch! — gritava Volódia. Mas Karl Ivánovitch, sem dar ouvidos, continuava a correr.

Foi assim até chegarem à floresta. Karl Ivánovitch parou e carregou a espingarda.

— Ora, ora — disse Karl Ivánovitch — agora é só encontrar essa lebre!

E Karl Ivánovitch embrenhou-se na floresta.

Volódia seguiu Karl Ivánovitch.

$\mathrm{Na}$ floresta estava escuro, fresco e tinha cheiro de cogumelo no ar.

Karl Ivánovitch segurava a espingarda preparada e olhava atrás de cada arbusto.

— Karl Ivánovitch! — disse Volódia. — Vamos voltar. Não precisa atirar na lebre.

— Não, não! — repetia Karl Ivánovitch. — Não me atrapalhe!

De repente, a lebre saiu detrás de um arbusto e, ao ver Karl Ivánovitch, deu um salto, girou no ar e pôs-se a correr.

— Pega! — gritava Karl Ivánovitch.

Volódia correu atrás de Karl Ivánovitch.

— O - o-o! — gritava Karl Ivánovitch. — Agora pego! Um, dois, três!

A barba preta de Karl Ivánovitch ondulava ao vento em todas as direções. Karl Ivánovitch saltava entre os arbustos, gritava e brandia as mãos. 
— Ufa! — disse Karl Ivánovitch parando e limpando a testa com a mão. — Ufa!

Como estou cansado!

Sentada num lugar mais alto, a lebre levantou as orelhas e olhou para Karl Ivánovitch.

— Ah, sua lebre tinhosa! — gritou Karl Ivánovitch. Ainda me provoca!

E Karl Ivánovitch voltou a perseguir a lebre. Mas depois de dar alguns passos, Karl Ivánovitch parou e sentou-se num toco.

— Não, não aguento mais — disse Karl Ivánovitch. 


\section{Um acontecimento misterioso}

Não dá para acreditar numa coisa dessa! Será que alguém pode me explicar o que aconteceu? Já é o terceiro dia que estou deitado no sofá tremendo de medo. Não estou entendendo nada. OCORREU O SEGUINTE:

No meu quarto, há na parede um retrato do meu amigo Karl Ivánovitch Shusterling. Anteontem, quando eu arrumava meu quarto, retirei o retrato da parede, limpei o pó dele e o pendurei de volta. Depois, afastei-me para olhar se o quadro não estava torto. Mas no que olhei, minhas pernas gelaram e os cabelos ficaram de pé. No lugar de Karl Ivánovitch Shusterling, lá da parede olhava para mim um velho barbudo e medonho com chapéu de bobo. Num grito, saí correndo do quarto.

Como pode Karl Ivánovitch Shusterling transformar-se naquele barbudo estranho de uma hora para outra? Ninguém consegue explicar isso...

Quem sabe você possa me dizer para onde se escafedeu meu querido Karl Ivánovitch? 
Certa vez, Pétia Pregov ${ }^{56}$ estava andando pelo apartamento. Ele estava morrendo de tédio. Apanhou do chão um papelzinho qualquer que a empregada tinha deixado cair. O papelzinho era um pedaço de jornal. Não era interessante. Pétia tentou correr atrás do gato, mas o gato se meteu debaixo do armário. Pétia dirigiu-se à entrada atrás do guardachuva para com ele tirar o gato debaixo do armário. Mas quando Pétia voltou, embaixo do armário já não havia gato nenhum. Pétia procurou o gato embaixo do sofá e atrás do baú, mas não o encontrou em parte alguma, em compensação, atrás do baú, Pétia achou o martelo. Pétia pegou o martelo e pôs-se a pensar no que daria para fazer com ele. Pétia pôs-se a martelar o chão, mas isso era maçante. Nisso, Pétia lembrou-se que na cadeira da entrada havia uma caixinha de pregos. Pétia foi até lá, escolheu alguns dos pregos mais compridos da caixinha e começou a pensar onde pregá-los. Se o gato estivesse ali, de certo seria interessante pregar o gato na porta pela orelha e, com outro prego, o rabo no batente. Mas do gato nem sombra havia. Pétia avistou o piano de cauda. E de tão entediado que estava, Pétia foi até o piano e pregou três pregos em sua tampa.

9-12-1936

\footnotetext{
${ }^{56}$ No original Гвоздиков (Gvózdikov), sobrenome derivado de гвоздить (gvozdit) que significa pregar, martelar.
} 


\section{Púchkin}

De uma feita, Kiril veio à minha casa e disse:

— Eu sei de cor "A tempestade em bruma o céu oculta, turbilhões de neve a $\operatorname{girar}^{57}$ "

— Muito bem — disse eu. — E você gosta desses versos?

— Gosto — disse Kiril.

— E você sabe quem os escreveu? — perguntei eu ao Kiril.

— Sei — disse ele.

— Quem? - perguntei a ele.

— Púchkin — disse ele.

— E você entende do que falam os versos? — eu perguntei.

— Entendo — disse Kiril. — Falam de uma casinha e uma velhinha.

— E você sabe quem é essa velhinha? — perguntei.

— Sei — disse Kiril. — É a vovó Kátia.

— Não — disse eu. — Essa não é a vovó Kátia. Essa velhinha se chama Arina Rodiónovna. É a babá de Púchkin.

— Mas por que Púchkin tem uma babá? — perguntou Kiril.

— Quando Púchkin era pequeno ele tinha babá. E quando o pequeno Púchkin deitava-se para dormir, a babá sentava-se ao lado da caminha dele e contava-lhe histórias ou cantava longas canções russas. O pequeno Púchkin escutava essas histórias e canções e pedia à babá que contasse ou cantasse mais. Mas a babá dizia: “Mais tarde. É hora de dormir". E o pequeno Púchkin adormecia.

\footnotetext{
57 Verso do poema "Noite de inverno" (Зимний Вечер), de Aleksandr Púchkin: “Буря мглою небо кроет, Вихри снежные крутя"
} 
— E quem é esse Púchkin? — perguntou Kiril.

— Como é que você conseguiu decorar os versos sem saber quem era ele! — disse eu. - Púchkin é um grande poeta. Você sabe o que é poeta?

- Sei — disse Kiril.

— Então diga o que é um poeta — pedi a ele.

— O poeta é aquele que escreve poemas — disse Kiril.

— Isso - disse eu. — Um poeta escreve poesias. E Púchkin é um grande poeta. Ele escreveu poemas admiráveis. Tudo o que Púchkin escreveu é admirável.

— Você disse que Púchkin era pequeno — disse Kiril.

— Não, - disse eu — você não entendeu direito. Primeiro, como todas as pessoas, Púchkin era pequeno, depois cresceu e ficou grande.

— E quando ele era pequeno escrevia poesias? — perguntou Kiril.

— Escrevia, sim — disse eu. — Mas primeiro, ele começou a escrever poesias em francês.

— E por que ele escrevia em francês, primeiro? — perguntou-me Kiril.

— Veja você, — disse eu a Kiril — naquele tempo, quando Púchkin viveu, era comum, nas casas ricas, se conversar em francês. E, então, os pais de Púchkin trouxeram para ele um professor de língua francesa. O pequeno Púchkin falava em francês tão bem quanto em russo, leu muitos livros franceses e começou a escrever poesias em francês.

Púchkin falava em francês com os pais, com o professor de francês e com a irmã, também. O pequeno Púchkin só falava em russo com a avó e com a babá. E foi assim, escutando as histórias e canções da babá, que Púchkin passou a amar a língua russa e começou a escrever poesias em russo.

Nesse instante o relógio pendurado na parede bateu duas horas.

— Bom, — disse eu para Kiril — já é hora de você ir passear na rua. 
— Ah, não — disse Kiril. — Eu não quero passear, me conta mais de Púchkin.

— Está bem, — disse eu — vou lhe contar como Púchkin tornou-se um grande poeta.

Com os pés na poltrona, Kiril preparou-se para ouvir.

— Bom, é mais ou menos assim, — comecei eu — quando Púchkin cresceu um pouco, mandaram-no para o Liceu. Você sabe o que é um Liceu?

— Sei, — disse ele — é um navio a vapor.

— Não, nada disso! — disse eu. — Que navio a vapor, que nada. O Liceu era como se chamava a escola onde Púchkin estudou. Naquela época era a melhor escola. Os meninos que lá estudavam tinham os melhores professores e pessoas ilustres visitavam o Liceu.

No Liceu, junto com Púchkin, estudavam trinta meninos. Muitos deles eram jovens poetas e escreviam poemas, também. Mas Púchkin escrevia poemas melhor que todos. Ele escrevia muito e, às vezes, havia dias em que ele as escrevia quase o tempo todo: durante as aulas em classe, durante o passeio no parque e, até mesmo, quando acordava cedo na cama, pegava o lápis, papel e começava a escrever poemas. Às vezes, os poemas não saiam bons. Então, ele mordia o lápis de raiva, riscava as palavras e tornava a escrevê-los novamente, corrigia os versos e os reescrevia algumas vezes. Mas, quando os poemas ficavam prontos, eram tão leves e bem escritos que parecia que Púchkin os escrevera sem o menor esforço.

Os colegas de Púchkin, no Liceu, liam e decoravam os seus poemas. Eles entendiam que Púchkin ia se tornar um grande poeta. E Púchkin escrevia poemas cada vez melhor e melhor.

E então, um dia, o velho Derjávin chegou para uma prova no Liceu...

— E por que ele veio? — perguntou-me Kiril. 
— Ah, sim — disse eu — talvez você não saiba quem é esse Derjávin. Ele também é um grande poeta e, antes de Púchkin, pensavam que ele era o melhor poeta, o rei dos poetas.

Derjávin já era bem idoso. Ele veio ao Liceu, sentou-se na poltrona, olhando para os alunos do Liceu com olhos sonolentos.

Mas quando Púchkin entrou e, com voz sonora, começou a ler suas poesias, Derjávin logo se animou. Púchkin estava a dois passos de Derjávin e lia seus versos em alto e bom som. A voz dele ressoava.

Derjávin escutava. Lágrimas surgiram nos seus olhos.

Quando Púchkin acabou, Derjávin levantou-se da poltrona e lançou-se para abraçar e beijar o novo grande poeta. Mas Púchkin, sem mesmo entender o que fazia, virou-se e saiu correndo; procuraram-no, mas não conseguiram encontrá-lo em lugar algum.

— Mas onde ele estava? — perguntou-me Kiril.

— Não sei — disse eu. — Deve ter se escondido em algum lugar. É que ele ficou muito feliz porque Derjávin tinha gostado de suas poesias!

— E Derjávin? — perguntou-me Kiril.

— E Derjávin — disse eu — entendeu, por sua vez, que tinha encontrado um novo grande poeta que poderia ser maior ainda do que ele mesmo.

Sentado na poltrona, Kiril permaneceu algum tempo em silêncio. E depois de súbito perguntou-me:

— E você viu o Púchkin?

— Você também pode ver o Púchkin — disse eu — nesta revista há um retrato dele.

— Não, — disse Kiril — eu quero ver o Púchkin em carne e osso. 
— Isso é impossível, — disse eu — Púchkin morreu exatamente há cem anos. Agora tudo o que restou dele é precioso para nós. Todos os seus manuscritos, até mesmo cada bilhetinho escrito por ele, as penas de ganso com as quais escrevia, a poltrona na qual ele então se sentava, a escrivaninha onde ele trabalhava. Tudo isso está conservado em Leningrado, no museu Púchkin.

<Enquanto isso, na Aldeia Mikháilovskoie, ainda existe a pequena casinha onde, naquela época, morava Arina Rodiónovna, a babá de Púchkin. Púchkin escreveu uma poesia sobre essa casinha e sobre sua babá. Esses são os versos que você decorou hoje.>

Kharms

(18 de dezembro de 1936) 


\section{A raposa e a lebre}

Era uma vez duas amigas: a lebre Rabinho Cinza e a raposa Rabinho Ruivo.

Cada qual construiu para si uma casinha e começaram a visitar-se uma à outra.

Era só a raposa não vir à casa da lebre, que a lebre ia correndo até a da raposa e gritava:

"Rabinho Ruivo! O que há com você?"

E se a lebre não ia à casa da raposa, então a raposa ia correndo até a da lebre e gritava:

"Rabinho Cinza! O que há com você?"

Uma vez a lebre Rabinho Cinza

chegou correndo para visitar a raposa ${ }^{58}$.

“Abra a porta!" Toc, toc, toc

De repente, a raposa ouviu: "Que batida é essa?

Está vendo: é tarde, logo anoitece.

É melhor você ir embora".

A lebre pensou: "Espere aí,

Eu também sei ser difícil”.

Então, a raposa Rabinho Ruivo

chegou correndo pra visitar a lebre.

“Abra a porta!” Toc! Toc! Toc!

Responde a lebre imediatamente:

"Não, meu bem, desse jeito não dá

Está a bater antes da hora!"

E desde então, as duas melhores amigas

estão sempre brigadas uma com a outra.

\footnotetext{
${ }^{58} \mathrm{O}$ texto original em russo apresenta rimas entre os versos a partir deste trecho.
} 
PARTE II 


\section{Do OBERIU ao Brasil}

\subsection{Realismo Socialista: a estética do novo regime.}

"Literatura não é, pois, cópia fiel da realidade, é criação do espírito e da inteligência, cujo meio de expressão é a linguagem, que, como vimos, é uma criação social."

(Antonieta Dias de Moraes, 1991, p. 69)

Após a Revolução Russa, em 25 de outubro de 1917, houve, num primeiro momento, certo clima de êxtase entre os artistas ligados aos ideais revolucionários. "Era uma época em que os artistas da vanguarda gritavam com o polêmico ardor dos vendedores de atacado" (RIPELLINO, 1996, p. 253) O poeta Vladímir Maiakóvski ${ }^{59}$ fez parte destes, tendo colaborado ativamente para o estabelecimento do cubo-futurismo enquanto estética do novo regime. A situação favoreceu uma atmosfera de intensa experimentação artística.

Entretanto, como observa Jean-Claude Lanne,${ }^{60}$ havia entre os cubofuturistas, por exemplo, determinada confusão entre a poética e a política. Percebia-se o rechaço a toda estética considerada antiquada e reacionária, na visão daqueles artistas politicamente engajados que se consideravam o baluarte da modernidade e do novo sistema. O que se evidenciava, então, era a tentativa de ruptura com uma tradição literária.

A busca por equivalência entre a revolução social e uma revolução das formas artísticas, preconizada por alguns grupos de artistas militantes, após alguns anos, tornouse a tônica do Estado Soviético. Porém, a Revolução não unificou os anseios de todos os artistas numa única proposta, muito pelo contrário, as mudanças político-sociais impostas

\footnotetext{
${ }^{59}$ Embora posteriormente Maiakóvski tenha sido perseguido pelo Partido e acusado de produzir um tipo de literatura incompreensível para as massas.

${ }^{60}$ In ETKIND, E. (Org.) Histoire de La littérature russe. Le XX siècle. L'Âge d'Argent. Paris: Fayard, 1987.
} 
pela nova ordem revelaram uma intelectualidade dividida e opiniões bastante díspares, tanto no que dizia respeito ao fazer artístico, quanto no tocante aos rumos da sociedade.

Grosso modo, a situação de instabilidade social face à guerra civil (1917 - 1921) gera onda emigratória que conduz para fora do país muitos artistas e intelectuais ${ }^{61}$. Em posição diametralmente oposta aos emigrados, estavam os artistas ligados ao Proletkult ${ }^{62}$, cuja proposta era a criação de uma "cultura proletária" a partir do contato direto com os sentimentos, ideias e experiências do proletariado.

Em posição intermediária, havia considerável gradação de movimentos, escolas artísticas e literárias que tomaram corpo com a Revolução, mas não necessariamente tinham o intuito de fazer dela seu único mote. Leon Trotsky, em sua obra Literatura e revolução, ao tratar da literatura no início do período soviético, pontuou um grupo de escritores que, segundo ele, apesar de não terem partido para o exterior, viviam como “emigrados internos" resistentes aos acontecimentos de Outubro.

As cenas literária e artística da época estavam marcadas por estilos variados, o clima, como um todo, era de expectativa e efervescência: cubofuturistas, construtivistas e acmeístas ${ }^{63}$, entre outros movimentos; além de artistas independentes, sem filiação coletiva, davam continuidade a suas atividades buscando adequação "às exigências dos novos tempos”. A Revolução era um fato irrevogável, mas podemos observar que entre

\footnotetext{
${ }^{61}$ Os escritores que deixaram a URSS criaram uma literatura de emigração, alguns se tornaram ainda bastante conhecidos ao produzirem vasto e significativo acervo, é o caso de Nina Berberova, Vladimir Nabokov e Joseph Brodsky, entre outros.

${ }^{62}$ Cultura proletária - пролетарская культура (prolietarskaia kultura) - organização e periódico fundados por A. A. Bogdanov e A. V. Lunatcharski no começo de 1917, com o objetivo de promover a literatura e a cultura proletárias; mesmo dentro do movimento havia ambiguidade quanto à literatura. (cf. ANDRADE, H.F., 2010, p. 154) Posteriormente, Maiakóvski, Meyerhold e Bédni estiveram engajados nesse movimento.

${ }^{63}$ Sobre esses movimentos. cf. Andrade, 2010, p. 156.
} 
os escritores, à época, havia variegadas atitudes no que diz respeito à inclusão e abordagem desse evento histórico em suas obras.

O Partido, por sua vez, conclamava a todos para a construção de uma arte participante. Na qualidade de país pioneiro a encabeçar uma Revolução proletária, a União Soviética foi também, como bem assinalou Moniz Bandeira no prefácio à edição brasileira de Literatura e Revolução; a primeira nação a ter que lidar, na prática, com o desafio de fornecer diretrizes condizentes com sua nova situação político-social para a literatura e para a arte, em geral.

Entre outras manifestações artísticas, a literatura protagonizava, então, papel de instrumento e agente revolucionário na construção da utopia social e, obviamente, estava incluída nos programas governamentais por sua capacidade pedagógica e formativa dos cidadãos soviéticos. Esse local de destaque da arte literária se justificava ainda mais, em primeiro lugar, pela força adquirida por ela ao longo da história russa, visto que, a literatura ocupara, em muitos momentos, o lugar da filosofia e da sociologia, ao trazer em seu bojo discussões que envolviam religião, política, costumes etc. Como sumarizou Joseph Frank (1992, p. 61-62):

Devido à dificuldade para expressar ideias controversas diretamente na imprensa (embora seja espantoso quantas dessas ideias conseguiam chegar até os periódicos devido à obtusidade - mas algumas vezes também à tolerância - da censura czarista), a literatura serviu, mais ou menos, como uma válvula de escape através da qual assuntos proibidos podiam ser apresentados ou, pelo menos, sugeridos.

Em segundo lugar, fora das fronteiras soviéticas, a literatura russa havia conquistado inúmeros leitores e gozava de boa imagem no restante da Europa. O Partido logo percebeu a oportunidade de usar dessas duas facetas para impor à literatura um caráter educativo e, ao mesmo tempo, marcá-la, para o resto do mundo, como cartão postal das conquistas do comunismo. A literatura infantil, sobre a qual trataremos mais 
tarde, não ficou incólume tendo em vista que a criança alcançaria, na URSS, papel fundamental no tocante à absorção e transmissão dos valores comunistas.

Claro estava que, aos escritores, seja lá para qual gênero se dedicassem, não era permitido prescindir do processo revolucionário.

É ridículo, absurdo e mesmo estúpido, ao mais alto grau, pretender que a arte permaneça indiferente às convulsões da época atual. Os homens preparam os acontecimentos, realizam-nos, sofrem os efeitos e se modificam sob o impacto de suas reações. A arte, direta ou indiretamente, reflete a vida dos homens que fazem ou vivem os acontecimentos. Isso é verdadeiro para todas as artes, da mais monumental à mais íntima. (TROTSKY, L., 1969, p. 24)

Trotsky, assim como Lenin, rechaçava a ideia de uma cultura ou literatura proletárias, pois a aceitação de tal vertente só poderia existir à medida em que a referida cultura do proletariado se opusesse à cultura burguesa. Ora, do ponto de vista trotskista, se a sociedade soviética se encaminhava para a planificação e para o apagamento das diferenças entre classes, consequentemente, em seu futuro não haveria contraposições culturais.

$\mathrm{Na}$ futura sociedade comunista e planificada só restaria espaço para uma única cultura, fruto do novo contexto ideal vindouro; haveria apenas a cultura soviética. Trotsky, entretanto, entendia que a literatura daquele momento, após a guerra civil, estava em fase de transição, em busca do que seria, de fato, a verdadeira literatura soviética uma vez atingidos os objetivos revolucionários.

Para que esses propósitos fossem conseguidos, seria preciso elevar o nível cultural do proletariado através do aprendizado com o legado deixado pelos escritores anteriores à Revolução, enquanto estes fossem necessários; porque os modelos para a criação da incipiente literatura soviética se encontravam nos cânones do passado literário russo, ou seja, na literatura burguesa. Por conta disso, Trotsky faz um apanhado crítico dos poetas e escritores do período categorizando suas produções e apontando quais poderiam servir de modelos artísticos para as novas gerações. 
Um grupo de escritores é destacado pelo teórico-político que assim os descreve:

Esses escritores são, em sua maioria, muito jovens: têm entre vinte e trinta anos. Não têm nenhum passado pré-revolucionário, e, se romperam com alguma coisa, foi, afinal de contas, com bagatelas. A Revolução formou, geralmente, sua fisionomia literária e intelectual, segundo o ângulo pelo qual os tocou. $\mathrm{E}$ todos eles a aceitaram, cada um à sua maneira. (...) Não são artistas da Revolução proletária, mas os seus companheiros de viagem na arte, no sentido em que a velha social-democracia emprestava ao termo. (...) Para um companheiro de viagem, a questão consiste sempre em saber até onde ele irá. Não se pode respondê-la por antecipação, nem mesmo por aproximação. (TROTSKY, L., 1969, p. 57)

Dessa maneira, surgem os chamados "popúttchiki" ou "Companheiros de Viagem", como ficaram conhecidos. Eles não eram escritores do Proletkult e não pertenciam a uma escola literária, em específico, mas o valor artístico de suas obras fazia deles modelos para os chamados artistas da revolução.

(...) no decorrer da década de 1920, a essa categoria de contornos indefinidos foram se juntando escritores que não militavam nas organizações proletárias ou partidárias, embora colaborassem em revistas e suplementos ligados a operários e camponeses, como é o caso de alguns "Irmãos de Serapião"64. (ANDRADE, 2010, p. 155)

No início da década de 1920, o Partido ocupou-se, prioritariamente, com questões

de cunho estrutural dentro do país e com reformas mais emergenciais em infraestrutura: organização de moradias, construção de estradas, deslocamento de contingentes humanos, reformas políticas etc. Por isso, a estrutura governamental ainda não tinha condições de monitorar integralmente a produção literária enquadrando-a nos moldes ideológicos do comunismo.

Assim, apesar de se fazer sentir uma crescente tendência à institucionalização no campo das artes, havia certo espaço deixado nas frestas do sistema político para a experimentação artística $^{65}$; situação que permitia a participação de artistas, outrora de vanguarda, como Maiakóvski, nas atividades culturais. Como exemplifica Homero

\footnotetext{
${ }^{64}$ Artistas que pregavam liberdade de criação. Nome do movimento alude à personagem de E. T. A. Hoffmann. cf. Andrade, 2010, p. 155.

${ }^{65}$ Em 1923, Maiakóvski funda a LEF (Frente de Esquerda das Artes) com intenção de fazer com que as artes acompanhassem de igual para igual a revolução social.
} 
Freitas Andrade (2010, p. 156), o poeta cubofuturista "criava versos e desenhos para campanhas publicitárias de saneamento básico" e construtivistas, como Vladimir Tátlin, propunham uma arte "inspirada na máquina e na industrialização a serviço da construção do mundo socialista".

Contudo, a inevitável e paulatina burocratização das artes, encabeçada pelo Partido, nos anos subsequentes às principais reformas, conduzia ao afunilamento da liberdade artística. O que se desvela é a tentativa de unificação da linguagem literária por parte do Partido e a perseguição aos Companheiros de Viagem. Tal enrijecimento político é intensificado com a ascensão de Josef Stálin ao poder, em 1925.

Esse espírito de adequação ideológica do fazer artístico ganha mais força e, em 1928, é criada a RAPP (Associação Russa dos Escritores Proletários) responsável por auxiliar o Partido no Primeiro Plano Quinquenal (1928 -32) a estabelecer adequações no âmbito da literatura russa. Através do "Plano Quinquenal" o Partido pretendia exercer transformações profundas nas esferas industrial, agrícola e social do país.

Grupos de críticos comunistas se manifestaram a favor da inclusão das artes neste projeto estatal e esta proposta foi apoiada por membros do Partido que apregoavam a arte como forma de propaganda do governo. Andrade (2010, p. 159) ressalta:

Nesse período, mais do que nunca, escritores e artistas eram convocados a participar dos esforços, formando caravanas para visitas às fazendas coletivas, às fábricas, usinas e outras megaconstruções, com o objetivo de apr(e)ender a realidade do recém-gerado homo sovieticus e promovê-la.

Ou seja, escritores, músicos, pintores e cineastas eram conclamados a mimetizar a "realidade" do cidadão soviético na construção da futura pátria socialista.

Em termos estéticos, após a I Guerra Mundial, havia na Europa como um todo certo movimento de retorno às estéticas pré-vanguardistas, no qual críticos vislumbravam o desejo de ordem e moderação a partir da utilização de materiais artísticos existentes. Peter Burger (1988, p. 81-95), ao refletir sobre as teorias de Adorno e discutir a questão 
do declínio da era moderna, suscita os exemplos de Picasso e Stravinsky que encenam uma volta às formas mais clássicas de composição, respectivamente com o quadro Olga na espreguiçadeira (1917) e com o balé Pulcinella (1919).

Entretanto, ao verificarmos a experiência soviética de "retorno" às formas de representação anteriores ao modernismo, observamos que o movimento de ruptura com o experimentalismo artístico não foi provocado apenas pelo desejo dos artistas frustrados com a violência de guerra, mas por imposição política. Ou seja, não lhes sobrava opção a não ser aderir ao modelo implantado pelo governo. Do mesmo modo, o realismo preconizado pelo governo soviético não era aquele praticado no fim do século XIX; como fazia questão de demarcar o Partido. O chamado Realismo Socialista, como viria a ser denominado, era uma estética propagandística que visava aos interesses do Estado a partir da supressão dos interesses artísticos e da tradição literária russa.

O retorno ao realismo, enquanto estética mais palatável às massas, fazia-se sentir na URSS e, como consequência, os escritores soviéticos eram obrigados a romper tanto com a tradição literária russa do fantástico e do maravilhoso, quanto suprimir os procedimentos vanguardistas de experimentação literária, afim de corporificar uma "nova literatura" para uma nova sociedade em gestação: a literatura soviética.

A partir do momento em que o Estado assume o controle da literatura, os escritores começaram a ser divididos em dois grupos: de um lado, autores que escreviam sob os ditames do governo e, do outro, aqueles que buscavam dar continuidade às características individuais de sua própria obra.

Os primeiros, mesmo escrevendo em consonância com o Partido, precisavam zelar para que nada em suas obras fosse motivo de desconfiança, pois qualquer vacilo poderia colocá-los sob suspeita de subversão e sabotagem. 
Enquanto que o segundo, era composto por escritores considerados, muitas vezes, como perigosos ao regime por produzirem uma literatura, de certa forma, mais calcada no âmago da criação moderna e por utilizarem, em suas obras, marcas do estilo individual, formas vanguardistas de experimentação linguística, associadas ao grotesco, ao fantástico, ao maravilhoso e ao absurdo. Estes eram perseguidos, sujeitos à vigilância, presos e, de acordo com Marc Slonim, taxados de burgueses, ou seja, inimigos do povo; raramente conseguiam publicar sua obra e, em geral, eram relegados ao ostracismo.

A ofensiva do realismo, encabeçada pelo governo, encontrava ressonância em todo um conjunto de escritores "ditos proletários e comunistas" que empenhavam-se na narrativa de caráter realista. Segundo Andrade (2010, p. 157): “Produziam a denominada literatura do fato (literatura fakta)". Os oberiúty, de quem trataremos mais adiante, também surgem nesse ínterim e, apesar de sua produção experimental ligada à arte do absurdo, também acompanham a exigência oficial de filiação à realidade. Em 1928, publicaram seu manifesto no qual levantavam questionamentos acerca do fazer artístico, apresentavam seus integrantes e expunham um programa de ação.

Em 1932, o Comitê Central do Partido decreta o fim de todas as associações literárias, mesmo aquelas que promulgavam a literatura oficial, e unifica todos os coletivos de escritores sob a mesma designação: a União dos Escritores Soviéticos. Àquela altura, todo tipo de experimentalismo artístico já era considerado ilegal. Em 1934, no Congresso dos Escritores, A. Jdánov, na qualidade de porta-voz do governo, faz um discurso no qual expõe o formato do Realismo Socialista, ao estabelecer parâmetros fixos de escrita para todas as obras literárias, bem como para a ação dos escritores dentro da URSS:

O nosso escritor extrai o seu material da epopeia heroica dos homens soviéticos, da experiência dos nossos kolkhozes ${ }^{66}$, da atividade criativa que fervilha em cada

\footnotetext{
${ }^{66}$ Propriedades agrícolas coletivizadas.
} 
canto do nosso país. No nosso país os protagonistas das obras literárias são construtores ativos de uma nova vida: operários e operárias, kolkhozianos e kolkhozianas, funcionários do partido, organizadores da economia, engenheiros, jovens da komsomol ${ }^{67}$, pioneiros. Eis os tipos e as personagens fundamentais da literatura soviética. A nossa literatura é pródiga em entusiasmo e heroísmo, é otimista [...] É otimista por natureza, enquanto literatura de uma classe em ascensão, o proletariado, única classe progressista e de vanguarda. (In: ANDRADE, 2010, p. 162)

A fala de Jdánov demonstra a aproximação entre as ideias do Partido às dos escritores anteriormente ligados ao Proletkult. O discurso prossegue e entre as exigências estavam a utilização da linguagem simples, a criação de heróis vinculados ao ideal socialista e o repúdio ao maravilhoso e ao fantástico e, sobretudo, vínculo com a verdade, sem distorção da natureza das coisas.

Os poetas, por exemplo, eram estimulados a buscar na poesia e canções tradicionais o linguajar e a métrica adequados para suas composições. A poesia experimental como a de Maiakóvski, fora declarada incompreensível para as massas ${ }^{68}$. Dentre os heróis, podemos citar Pávlik Morózov, garoto que, após ter supostamente denunciado o próprio pai como contrarrevolucionário, foi assassinado por parentes, em vingança. Após sua morte, Pávlik tornou-se uma espécie de mártir, tendo sua história servido de inspiração para muitos escritores de LIJ (literatura infanto-juvenil), na União Soviética $^{69}$.

O romance de Nikolai Ostróvski, Assim foi temperado o aço, é outro exemplo do estilo realista socialista, enquanto literatura em prol da causa socialista; nele é contada a história do jovem Pável Korcháguin, ativista da Komsomol (União da Juventude Comunista), cujo amor à pátria soviética inspirou gerações de crianças e jovens, dando-

\footnotetext{
${ }^{67}$ União da Juventude Soviética.

68 “(...) Quarentena é inútil contra eles —/ mandolinam por detrás das paredes: / 'Ta-ran-tin, ta-ran-tin, / ta-ran-te-n-n... '(...)”; versos do poema “A plenos pulmões”(1929 -30), de Maiakóvski, com tradução para o português de Boris Schnaiderman com Augusto e Haroldo de Campos.

${ }^{69}$ Sergei Eisenstein dirigiu um filme, "O Prado de Bejin", inspirado em sua história.
} 
lhes coragem e crença em sua missão de transformação social. Em narrativas como essa não havia espaço para nada além da "realidade". Segundo Slonim (1974, p. 198):

O Realismo Socialista, método básico da literatura e da crítica literária soviéticas, exige do artista uma representação verídica, historicamente concreta da realidade e seu desenrolar revolucionário. Ademais, a verdade e a integridade histórica da representação artística devem combinar-se com a tarefa de transformar ideologicamente e educar o homem que trabalha dentro do espírito do socialismo.

Enfim, os escritores soviéticos eram conclamados a adotarem um ponto de vista altruísta em relação aos projetos governamentais, mesmo que, para tanto, fosse necessário edulcorar uma realidade dura e triste com finais felizes dignos de contos da carochinha. Qualquer crítica ao regime, por menor que fosse, era vista como um entrave ao estabelecimento da pátria soviética sendo, portanto, cabalmente combatida. Tal ambiência é o pano de fundo por trás da obra de Daniil Kharms, de quem trataremos a seguir.

\subsection{Daniil Kharms: vida e vanguarda.}

Em 1927, a procura de escritores para colaborarem com a concretização de seu projeto junto à LIJ soviética, Samuil Marchák ${ }^{70}$ convida alguns amigos oberiúty para contribuírem com seu trabalho, tendo percebido que os elementos da estética desses artistas - jocosidade, apego à forma, criação de palavras, jogos sonoros etc. encontravam espaço e possibilidade de aplicação nas obras para crianças. Dessa forma, Kharms passou a colaborar ativamente com a autoria de obras infantis, trabalho que lhe garantiria o sustento e a dedicação à sua grande paixão: a literatura.

Daniil Ivánovitch Iuvatchov, nasceu em 30 de dezembro de 1905, na cidade de São Petersburgo. Ele ficaria conhecido por seu pseudônimo mais usado e, também, do

\footnotetext{
${ }^{70}$ Escritor, tradutor e líder do projeto encaminhado pelo "Instituto de Educação Pré-escolar", cujo objetivo era a criação de uma biblioteca para a literatura infantil.
} 
qual mais gostava: Kharms. O hábito de adotar outros nomes manifestou-se ainda na escola $^{71}$ : Shardam, Dandan, Karl Ivánovitch Shusterling ${ }^{72}$, Vánia Mokhov e Bach eram alguns deles, com os quais seus contos eram assinados.

Sua predileção pelo apelido Kharms se dava tanto pelo fato deste possuir uma sonoridade interessante, quanto lembrar a mescla das palavras charms e harm (em inglês, respectivamente, encanto e dano). Além de possuir diferentes possibilidades de pronúncia, podendo ressoar como harm (fácil, em alemão) e charm (encanto, em francês $)^{73}$. Alguns pesquisadores também aderem à tese de que o nome "Kharms" remetia aos de Elisabeth Kharmsen, antiga professora da escola alemã, onde ele estudara, e ao de Sherlock Holmes, uma de suas personagens prediletas a quem ele, inclusive, imitava na maneira de se vestir. (Kobrinski, 2009, p. 17)

Sua paixão pela literatura manifestou-se desde a infância ${ }^{74}$, mas durante os anos de escola (1915 - 1924) a atividade literária era apenas um passatempo para o jovem futuro escritor. No período ginasial, Kharms escrevia poesias nas quais brincava com o metro e a sonoridade dos versos, demonstrando, desde então, em seu estilo a orientação para a mescla entre a poesia russa do século XIX com a lírica de vanguarda ${ }^{75}$.

Em 1925, Kharms ingressou na União dos Poetas de Toda as Rússia e, no mesmo ano, tornou-se membro da "Ordem dos Transmentais DSO" (Ордем заумников DSO), organizada pelo poeta “zaum” A. Tufánov. Este grupo pretendia levar adiante os estudos

\footnotetext{
${ }^{71}$ Em 1922, Daniil, que havia se mudado para em Diêtskoe Seló, ingressa na escola comum local, para frequentar o curso ginasial. Sua tia Natália Ivânovna Koliubákina, era diretora e professora de literatura russa na instituição. O ensino primário havia sido cursado na escola alemã St. Petrischule, fechada após a Revolução.

${ }^{72}$ Por vezes, Karl Ivánovitch Shusterling figurava enquanto personagem nas histórias de Kharms.

${ }^{73}$ Kharms falava alemão e inglês desde a infância. Chegou, inclusive, a traduzir para o russo "Plisch und Plum”, de Wilhelm Busch.

${ }^{74}$ Daniil Kharms, desde cedo aprendeu a gostar das "fantásticas histórias" que ouvia no aconchego da casa paterna, muitas das quais haviam sido escritas pelo próprio pai, também contista, Ivan Pávlovitch Iuvatchov. Este gosto pelo fantástico seria, mais tarde, transferido para o conjunto de sua obra.

${ }^{75}$ Ao término do período escolar, em 1924, Kharms ingressa no Instituto Eletrotécnico de Leningrado São Petersburgo recebeu o nome de Petrogrado (1914 - 24) e, posteriormente, de Leningrado (1924 - 91). Ainda no mesmo ano, conhece Esther Rusakova, sua primeira esposa, com quem se casaria em 1928.
} 
e experimentações com a "linguagem zaum"76 que, em poesia, relacionava-se ao

balbuciar informe de vocábulos inexistentes, à mistura de tramas e de nexos arbitrários.

Kharms procurou, assim, realizar a extensão de tal técnica à prosa, como veremos

adiante. A partir desse momento, além de tornar-se conhecido no meio literário local, o jovem escritor passou a estreitar relações com outros artistas que também compartilhavam dos mesmos anseios estéticos. No período, Kharms buscava referências poéticas no folclore russo; seus poemas continham trocadilhos fonéticos e inserções gráficas, como, por exemplo, o ideograma ${ }^{77}$ criado por ele para referir-se à futura esposa e que aparece desenhado em algumas poesias.

Em $1926^{78}$, este grupo passa a se designar como "Flanco Esquerdo" (Левый фланг — Liévyi flang) donde surgem os "tchinary"79 que pretendiam dedicar-se ao estudo da filosofia e da literatura; promoviam saraus literários. (Lima, 2001, p. 12) Entre 1926 e 1927, Kharms publica dois poemas, sendo estes os únicos trabalhos, fora do projeto de literatura infantil, que conseguiu editar, em vida. Paralelamente, dedica-se ao teatro e escreve as peças Comédia da cidade de Petersburgo (Комедия города Петербурга) е Elisavieta Bат (Елизавета Бам) ${ }^{80}$.

\footnotetext{
76 "O que é zaum? Foi A. Krutchónikh quem cunhou o termo, juntando a preposição 'za' (além de, atrás de, através de) e o substantivo 'um' (mente, inteligência) (...) Para essa língua sem nome, ele pensou numa série de denominações 'língua livre', 'língua inventada', 'língua que não tem um significado', 'língua universal', 'fono-imagem'; mas prevaleceu o termo zaum por melhor explicitar a intenção almejada, ou seja, dar voz àquilo que se encontra além do logos, que se diferencia da 'língua comum' ou 'língua dos conceitos'. (...) o poeta proclamava a insurreição da palavra contra o sentido, símbolo manifesto da razão (um): a língua livre ultrapassa as fronteiras da razão e torna-se 'za-um', transmental (...)" In: Andrade, 1985, p. 52-54. O poeta Velimir Khlébnikov, que propunha associações sonoras a partir de radicais existentes nas línguas, está entre os membros mais representativos dessa linguagem.

${ }^{77}$ Kharms costumava desenhar em seus poemas, cartas e manuscritos, um pequeno retângulo cortado ao meio horizontalmente por um traço. Este ideograma representava, ao mesmo tempo, uma janela e também sua esposa Esther.

${ }^{78}$ Ano em que foi expulso do Instituto Eletrotécnico de Leningrado, aos 13 de fevereiro de 1926.

${ }^{79}$ Derivação de "tchin", em russo чин, que significa grau, categoria, ordem. Na sociedade tzarista, cada membro da nobreza, forças armadas e funcionalismo público possuía seu tchin, ou seja, seu grau de nobreza. ${ }^{80}$ Encenada em 1928.
} 
Em 1927, os "tchinary” inspirados pelo desejo de apresentar uma nova leitura do "realismo" através do uso de associações não convencionais tanto de palavras, quanto de objetos decidem se reorganizar sob nova sigla. Assim, os jovens escritores Aleksandr Vvedénski, Konstantin Váguinov, Igor Bákhterev, Nikolai Zabolótski, Daniil Kharms e Dóivber Lévin fundam a OBERIU ${ }^{81}(1927$ - 31) — Associação da Arte Real.

Tendo seguido a esteira dos movimentos de renovação das artes no início o século $\mathrm{XX}$, o grupo deu sequência às experimentações artísticas outrora realizadas pela vanguarda, aprofundando os estudos com a língua literária, sobretudo com a palavra e a forma, afim de revelar seus significados fundamentais e absolutos.

As diferentes denominações adquiridas pelos artistas em curto espaço de tempo é um exemplo da volatilidade apresentada pelos movimentos daquele momento histórico. A OBERIU foi considerada um último suspiro da vanguarda russa, antes do total abafamento pelo Partido; manifestava-se em prol da arte de esquerda e pretendia abrir caminho para uma nova cultura artística proletária.

Os participantes deste movimento, autointitulados “oberiúty”, buscaram associar o experimentalismo às demandas político-sociais da nascente União Soviética, com vistas à obtenção de uma atitude artística engajada, sem abrir mão dos preceitos estéticos compartilhados por seus integrantes. "Nós não somos apenas criadores de uma nova língua poética, mas também fundadores de um novo sentimento da vida e de seus objetos” (Kharms, 1994, p. 280), afirmavam eles.

Os artistas do grupo procuravam usar, em seus saraus, a mesma estratégia outrora utilizada pelos cubofuturistas, no que se refere à atitude de exibicionismo teatral destes (RIPELLINO, A. M., 1971, p. 22), ou seja, ensejavam provocar o estranhamento nos

\footnotetext{
${ }^{81}$ Em russo, ОБЭРИУ (Объединение реального искусства) - Obediniênie reálnovo iskússtva. O nome da associação é uma sigla composta pelas iniciais de "Associação da Arte Real". Contudo, podemos verificar que a letra "U”, esteja sobrando e teria sido acrescentada por brincadeira — OBE (Obediniênie); R (reálnovo); I (iskússtva). (Nota de rodapé. In: Gibian, 1974, p. 193).
} 
expectadores com apresentações não convencionais e chocantes. Kharms, por exemplo, em um evento do grupo se apresentou fumando, sentado sobre um armário. Solomon Volkov (1997, p. 395) descreve a cena da seguinte maneira:

Nas tardes literárias dos oberiútys, enquanto outros membros do grupo declamavam suas obras andando de bicicleta em torno do 'palco', Kharms seria conduzido, coberto de talco, ao topo de um imenso armário preto laqueado, e recitaria, numa voz monótona, seus versos infantis. (grifos nossos)

Assim, a trupe rapidamente atraiu os olhares vigilantes e reprovadores da crítica pró-realismo, pois o caráter contestador dessa arte não era útil ao Partido.

É interessante observarmos que, embora reunidos num coletivo, seus integrantes possuíam individualmente propostas artísticas próprias, embasadas em métodos experimentais. Eles apresentam-se da seguinte forma: "Nós, oberiúty, somos honestos trabalhadores de nossa arte. Nós somos poetas com uma nova disposição frente ao mundo e com nova arte" (Kharms, 1994, p. 280). Sua forma de "trabalho" foi divulgada, em 1928, na revista "Anúncios da Casa da Imprensa"82, com a publicação do "Manifesto OBERIU"83; no qual, num texto conciso de poucas páginas, Daniil Kharms e seus companheiros expunham os fundamentos de seu projeto e forma de atuação no âmbito da literatura e da artes. Kharms é citado da seguinte maneira:

Daniil Kharms, poeta e dramaturgo cuja atenção não está concentrada em uma figura estática, mas na colisão de uma série de objetos, em suas relações. No momento da ação, o objeto recebe novos contornos concretos cheios de um sentido real. A ação virada do avesso de um novo jeito, conserva em si "um traço clássico" e, ao mesmo tempo, representa em grande escala disposição oberiu frente ao mundo. (Kharms, 1994, p. 282)

A divulgação deste manifesto ${ }^{84}$ naquele momento, demonstrou ser uma atitude bastante audaciosa desses artistas que prenunciam, em tom de paródia, os decretos oficiais

\footnotetext{
${ }^{82}$ A Casa da Imprensa, em Leningrado, era um dos últimos redutos da reminiscente vanguarda até a total proibição da arte experimental, em 1932. cf. Volkov, S.

${ }_{83} \mathrm{O}$ texto do Manifesto foi escrito por Zabolótski.

${ }^{84}$ OBERIU parodia atitude dos cubofuturistas que haviam divulgado sua estética através dos Manifestos:

"Viveiro de juízes" (1910), "Bofetada no gosto público" (1912) e "A palavra enquanto tal" (1913). cf. Andrade, H. F., 1985.
} 
e se posicionam enquanto os reais representantes da "arte do real", antecipando o ato governamental de institucionalização do Realismo Socialista. Isso ocorre ao passo em que Kharms e seus companheiros captam a demanda do Partido por uma representação edulcorada da situação político-social soviética através da literatura.

Contudo, ao invés de se enviesarem pela dominância do conteúdo inerente à obra, como determinavam as autoridades soviéticas, os oberiúty privilegiam a busca por novas formas artísticas e procedimentos estéticos capazes de abarcar aquela realidade; era justamente na força do "método" capaz de representar "qualquer tema" que residia a atitude "revolucionária" do grupo.

Essa característica marca a filiação oberiu ao cubofuturismo, cuja forma e conteúdo de uma obra são equiparados em termos de valor, como ressaltada por Krystyna Pomorska, em seu livro Formalismo e futurismo (1972, p. 161): “O próprio material exerce a função 'expressiva' na poesia; consequentemente, não há oposição entre o material e a forma, já que os dois são igualados. "

O "Manifesto OBERIU" revela que as propostas coletivas da associação se estendiam, para além da literatura, às artes plásticas, ao cinema, ao teatro ${ }^{85}$ e exprimiam intenções de introdução da música no mesmo rol. A inclusão das mais antigas formas humanas de expressão criativa — poesia e música — ao lado da novíssima e, em ascensão, arte cinematográfica, mostra-nos a versatilidade dos oberiúty para lidar com a multiplicidade de linguagens artísticas de seu tempo, a intenção do grupo em abarcar as diferentes formas de arte sob o mesmo guarda-chuva procedimental sinalizava uma

\footnotetext{
${ }^{85}$ Desde 1925 , Kharms e seus companheiros de vanguarda participavam de saraus nos quais a diversidade de formas artísticas fazia-se notar.
} 
atitude bastante atual, para a época, no que diz respeito ao rompimento de fronteiras entre as artes e à criação de formas híbridas.

Segundo Vera Bonnemasou (2002, p. 117), a chamada hibridização — mistura entre artes diferentes ou entre meios variados no interior de uma única forma artística é uma tendência, com origens no Romantismo, que objetivava o aumento da capacidade de percepção através do uso de recursos sinestésicos. A hibridização artística vem a ganhar força, no transcorrer do século $\mathrm{XX}$, a partir do questionamento dos valores vigentes, possibilitando atingir o leitor em níveis mais altos de singularidade ou estranhamento.

Verificamos que, a simultaneidade de linguagens diferentes na composição de uma única obra é característica marcante da arte moderna, também manifesta no trabalho dos oberiúty, por isso eles garantem: "Nossa liberdade para a criação é universal: ela desliza por toda a diversidade da arte e irrompe para a vida, abraçando-a por todos os lados." (Kharms, 1994, p. 280) Desse modo, Kharms e seus companheiros seguem essa tendência, já utilizada pelas vanguardas precedentes, e unem várias formas de arte em seus saraus que incluem exibição teatral, declamação de poesias, danças performáticas, exposição de pinturas e filmes em apresentações nada convencionais.

Embora grande parte de suas empreitadas desse teor, não tenha sido executada por questões políticas, pois tais projetos que combinavam seriedade com bufonaria, experimentalismo cênico e desintegração da linguagem contrastavam com o direcionamento da política cultural para formas de representação mais convencionais, tentando com isso privilegiar, sobretudo, o conteúdo do objeto artístico.

Em seguida, o Manifesto toca num ponto central para as questões de cunho literário naquele momento e, também, para o próprio governo: a necessidade de 
atualização da arte tendo em vista sua defasagem diante do "gigante avanço revolucionário da cultura". No discurso oberiúty, observamos a crítica à prepotência dos grupos artísticos que aspiravam ser a única voz da arte proletária. Por isso, denunciam: "Ainda seria mais absurdo pensar que uma $\mathrm{AKHR}^{86}$ qualquer carregue consigo a semente da nova arte proletária.” (Kharms, 1994, p. 279). Essa discussão alude e abre espaço à pluralidade de linguagens, à riqueza das formas experimentais modernistas e rejeita a ideia de confinamento do escritor num único modelo ou escola literária. Dessa maneira, os oberiúty acabam pondo em xeque as intenções partidárias no tocante à imposição de um único estilo mimético — o Realismo Socialista.

O grupo OBERIU, por sua vez, buscava novos métodos de representação apoiando-se em procedimentos experimentais, conforme citamos acima, trazidos de outras vanguardas e, nesse sentido, ia na contramão das intenções da política cultural que visava à configuração de uma estética oficial única. A filiação oberiu à vanguarda pode ser observada tanto através da forma como atuavam junto ao público com apresentações chocantes, quanto no discurso teórico do movimento; mais concreta e especificamente ao longo do texto do Manifesto por meio da defesa expressa de Igor Tenrentiév — diretor teatral cuja montagem de $O$ inspetor geral $^{87}$, de Nikolai Gogol, foi duramente criticada

\footnotetext{
${ }^{86}$ Fundada, em 1922, como Associação dos Artistas Revolucionários da Rússia (AXPP - AKHRR) preconizavam uma arte ligada ao realismo e, atacavam a arte de vanguarda. Em 1928, passa a de designar Associação dos Artistas Revolucionários (AXP).

${ }^{87}$ A peça foi exibida ne Casa da Imprensa, seu cenário e figurinos (chamados "figurinos falantes") foram produzidos por Pável Filonov. Volkov (1997, p. 400) conta os detalhes da apresentação: "Monologando, os personagens trocavam de idioma, do russo para o francês, polonês ou alemão, irrompendo com canções ciganas ou árias de Rimski-Korsakov. Em dado momento, solenemente, o herói toma a direção do sanitário, ao som da Sonata do luar, de Beethoven. Em geral, o banheiro era parte importante na produção de Terentiev: os atores estavam constantemente indo à latrina, e intercalando grunhidos e gemidos com o texto de Gogol. As plateias soviéticas nunca haviam visto nada parecido; a interpretação erotizada embaraçou até mesmo os críticos mais avançados.” Terentiév foi executado em 1937, nos expurgos stalinistas.
} 
— e também por meio do apoio à pintura e arquitetura experimentais de Pável Filónov e Kasimir Malévitch ${ }^{88}$.

Daniil Kharms, por exemplo, era amigo e grande admirador das concepções artístico-filosóficas de Malévitch, a quem, inclusive, dedicara o poema "Iskuchénie" 89 (1927). Segundo Aaron Scharf (1991, p. 100): “A geometria de Malévitch fundamentava-se na linha reta, forma elementar suprema que simboliza a ascendência do homem sobre o caos da natureza". De certo modo, o minimalismo das formas suprematistas, nas artes plásticas, relacionava-se às características de objetividade e ausência de adornos da literatura kharmisiana. Abordaremos melhor essa questão em nossa análise.

Na sequência, o "Manifesto OBERIU" expõe mais uma de suas premissas de trabalho que diz respeito à universalidade e acessibilidade do trabalho artístico, ou seja, elementos exigidos de uma arte participante, que estivesse a serviço da sociedade.

Nós ovacionamos a demanda de uma arte acessível, compreensível em sua forma até para um escolar de aldeia, mas a demanda única de tal arte leva ao labirinto dos mais terríveis erros. (...) Nós sabemos muito bem ser impossível encontrar, de pronto, uma única saída correta para a situação criada. (...) O OBERIU penetra no coração da palavra, da ação dramática e da sequência cinematográfica. (Kharms, 1994, p. 279 - 280)

A utilização de linguagem simples era também uma demanda do Partido, que possuía um projeto para a literatura ligado às políticas educacionais, portanto, a partir do pressuposto de que os proletários deveriam ser capazes de entendê-la com facilidade e vissem nela um espelho de seu cotidiano de operário. Porém, a tentativa de renovação das formas de apreensão da realidade ensejada pelos oberiúty dispensava a simplificação

\footnotetext{
${ }^{88}$ Ambos fizeram parte do Instituto Nacional de Cultura Artística. Filónov teve a obra proibida no fim da década de 1920 e morreu de inanição,em 1941, durante o Cerco de Leningrado; Malévitch foi mentor do "Suprematismo", movimento artístico que lidava tanto nas artes plásticas, quanto arquitetônica com as formas geométricas elementares; ele morreu na miséria em 1935, após ter sido preso e torturado.

${ }^{89}$ Em russo, "искушение” significa tentação, sedução.
} 
pretendida pelo governo, pois extraía dessa mesma realidade elementos maravilhosos e absurdos.

A literatura soviética fomentada oficialmente estava embasada no realismo ${ }^{90}$; elemento parodiado pelos oberiúty por meio do nome da associação "da arte real"91. Entretanto, como bem assinalou Vladímir A. Karpov ${ }^{92}$, em um artigo sobre a literatura infantil de Kharms, ao invés do substantivo "realismo" empregado na nomenclatura da estética oficial ${ }^{93}$, os jovens vanguardistas preferem utilizar o adjetivo "real". Embora, o substantivo e o adjetivo possuam a mesma raiz, ambas suscitam ideias diferentes, visto que o "Realismo" remete ao método de representação da realidade, enquanto o adjetivo "real" qualifica o tipo de arte preconizada pelos oberiúty: uma arte real. Isto é, os jovens vanguardistas abrem um leque de possibilidades de interpretação de uma mesma realidade, dando-lhe conotação de autenticidade, independentemente do modo em que for representada e, assim, possibilitam com sua arte a denúncia bem humorada das mazelas sociais.

Eles reafirmam sua filiação às formas não convencionais de representação: "Nós ficamos fascinados com a beleza uma mulher retratada em pintura, ainda que, contrariando a lógica anatômica, o artista tenha virado os ombros de sua heroína, desviando-os para um lado.” (Kharms, 1994, p. 281). Ou seja, os oberiúty tomam como arte obras que vão além do registro fotográfico do objeto representado.

Kharms e seus companheiros, por meio do Manifesto, assumem a postura de pesquisadores de um novo método artístico ainda em construção, por isso deixam claro o

\footnotetext{
90 “реализм”.

91 “(...)реального искусства”

92 cf. Kárpov, A. V.

93 Alguns anos depois o governo oficializaria a estética do Realismo Socialista (Социалистический реализм).
} 
caráter experimental de seus procedimentos formais: "Nós não somos presunçosos a ponto de olhar para nosso trabalho como algo realizado até o fim." (Kharms, 1994, p. 280). Nessa busca, os oberiúty se apresentam como “(...) um novo destacamento da arte revolucionária de esquerda.” (Kharms, 1994, p. 280)

O Manifesto apela para a concretude da arte contrapondo-a à poesia zaum que, segundo asseguram, destitui a palavra de sentido e a torna impotente. Dessa maneira, ao invés de retirar o sentido da palavra, os oberiúty pretendem agregar-lhe novas significações e aprofundá-las. Por conta disso rechaçam o título de zaúmniki ${ }^{94}$ de maneira categórica.

Nesse ponto, o grupo mostra seu diferencial em relação ao cubofuturismo para o qual a linguagem zaum era "a pedra de toque". Sobre essa mesma questão, verificamos ainda um ponto de contraste entre as linhas gerais do grupo e a linguagem kharmisiana individualmente, pois Kharms era admirador do poeta Velimir Khlébnikov e de suas pesquisas com zaum ou linguagem transmental, tendo estas experimentações feito parte de sua formação enquanto poeta. Veremos adiante que o escritor oberiúty leva para sua obra infantil traços dessa linguagem.

Por fim, o "Manifesto OBERIU" apresenta seus trabalhos iniciados no cinema e no teatro, por meio da apresentação do Filme N. $1^{95}$, de autoria e direção de Aleksándr Razumóvski e Klementi Mints; bem como da peça Elizaveta Bam, de Kharms. Em ambos os projetos, há marcas do experimentalismo, sendo a principal delas a busca por uma linguagem própria, através da desvinculação entre a técnica artística e o conteúdo veiculado pelo enredo.

\footnotetext{
${ }^{94}$ Derivação de "zaum"; modo como eram chamados, os poetas adeptos das experimentações com essa linguagem.

${ }^{95}$ Infelizmente, a película desse trabalho não chegou aos nossos dias.
} 
No cinema, os oberiúty pretendiam fazer prevalecer a atmosfera: "Toda a essência dessa 'atmosfera', própria do material dado, é o tema.” (Kharms, 1994, p. 283). Enquanto que o teatro daria atenção especial aos elementos teatrais, ao trabalho em cena, por isso, a OBERIU descartava a possibilidade do teatro imitar a vida: "Porque um objeto e um evento, quando transportados da vida para a cena, perdem sua conformidade com as leis 'da vida' e adquirem outra lei — a teatral”. (Kharms, 1994, p. 284).

Ou seja, há um rompimento com a estrutura convencional da obra realista socialista, cujo centro é a história narrada enquanto mímese da realidade e a moção de vários os procedimentos da arte para assim representá-la, promovendo adesão do público à ideologia dominante.

Quando esses escritores relegam para segundo plano o conteúdo fabulado, descartando a veiculação da narrativa realista e ideologicamente comprometida, automaticamente entram em conflito com a literatura partidária soviética. O "Manifesto OBERIU”, apesar das tentativas de adequação à arte de esquerda e à Revolução, deixa claro que o tipo de arte praticada pelo grupo seguia na direção contrária àquela cuja intenção estava centrada no didatismo artístico, na promoção de inspiradores heróis soviéticos e na narrativa moralmente engajada.

Em seu projeto, os oberiúty foram capazes de concatenar a semente de diversas modalidades artísticas ainda latentes naquele momento, antecipando tendências que só viriam a ser desenvolvidas anos depois fora dos limites territoriais soviéticos.

No ano anterior à publicação do Manifesto, Kharms havia recebido um convite que lhe abriria novas possibilidades enquanto escritor, como vimos, pois fora convidado a ingressar na "Associação de escritores de literatura infantil". É certo que ele não manifestava nenhum apreço pelo público mirim e, podemos supor que, nunca havia se 
imaginado como escritor de literatura infantil, apesar de sua obra "para adultos" estar repleta de elementos que podem ser considerados como próprios da literatura para criança. Em seus diários encontram-se algumas alusões, no mínimo antipáticas, acerca de seu desprezo por velhas e crianças:

Muitos consideram as mulheres criaturas imperfeitas. Mas eu de modo algum! Ao contrário, até as considero muito agradáveis. Uma mulher jovem e cheinha! Em que ela é imperfeita? Não é imperfeita em absoluto. Já as crianças são outra coisa. Sobre elas dizem que são inocentes. Eu considero que elas também podem ser inocentes, só que são muito repugnantes, sobretudo quando dançam. Eu sempre vou embora da casa onde há crianças. (KHARMS, 2009, p. 552)

Outro exemplo dessa ojeriza é relatado por seu amigo Aleksandr Razumóvski que, em visita à casa do escritor, em 1926, teria observado a seguinte inscrição sobre um abajur: "Aqui se matam crianças." (Kobrinski, 2009, p. 50). Contudo, se por um lado, Kharms não se via como autor de trabalhos "para criança", por outro, naquele momento a publicação de obras de literatura infantil por escritores que escreviam para público em geral, era bastante difundida. Com o agravante de que as possibilidades de escritores, não ligados ao governo, verem seus trabalhos publicados eram escassas, quando não, remotas. De modo que, a literatura infantil constituía-se numa das poucas possibilidades de trabalho assalariado para uma classe inteira de poetas e escritores.

Até 1930, Kharms dedicou-se paralelamente à literatura infantil e ao OBERIU, quando seus membros foram chamados de "inimigos de classe" 96 . Assinado por L. Nilvitch, o texto intitulado "Malabarismo reacionário: sobre uma empreitada de vândalos", afirmava que o movimento era um "protesto contra a ditadura do proletariado" (Nikolaiev, 2000, p. 725).

\footnotetext{
${ }^{96}$ Orlando Figes coleta, em seu trabalho, o testemunho de soviéticos contemporâneos a Kharms. No seguinte relato podemos perceber o peso moral e a gravidade das acusações inferidas ao escritor. (FIGES, 2007, p. 287): "Todos tinham medo de nós. Tinham medo de conversar conosco, até de se aproximar de nós, como se tivéssemos uma praga que pudesse infectá-los... Nossos vizinhos nos evitavam, proibiam seus filhos de brincar conosco... Em 1936, (...) ninguém dizia nada sobre 'inimigos do povo' - havia apenas silêncio. Mas por volta de 1937 todos nos chamavam 'inimigos do povo'.” (Tradução nossa)
} 
Kharms, uma vez classificado de arruaceiro e detrator da ditadura do proletariado, ficou sob observação das autoridades. Alvo de críticas, por conta do perfil de suas apresentações, o movimento OBERIU não resistiu.

Após o esfacelamento do OBERIU, Kharms, continuou a publicar sua produção para crianças, mas naquele momento, o regime soviético impunha tanto aos artistas, quanto aos cidadãos, em geral, inúmeras restrições. Todas as obras literárias, mesmo aquelas destinadas ao público infantil, eram espreitadas de perto pelo Partido.

Nesta conjuntura de arrocho às manifestações artísticas, Kharms seguia com a publicação de textos para crianças, além de realizar traduções de autores como Wilhelm Busch (1832 - 1908). Sabemos, entretanto, que grande parte de sua produção literária — contos, uma novela, peças teatrais, poemas, textos teóricos — não foi publicada à época em que foi escrita, pois o escritor não aderiu ao assim chamado Realismo Socialista. Os trabalhos que ele dedicou ao público "adulto", entre eles sua série Incidentes ${ }^{97}$ (1933 1939) e a novela $A$ velha ${ }^{98}$ (1939) não saíram da gaveta ${ }^{99}$.

Em dezembro de 1931, ele foi preso devido ao caráter de sua poesia, considerada subversiva. Ao responder o questionário ao qual foi submetido na prisão, o escritor admite sua "culpa": "Resumindo minha declaração, reconheço, que a atividade de nosso grupo no campo da literatura infantil tinha caráter antissoviético e causou danos significativos à causa educacional da jovem geração soviética" (Kharms, 2011, p. 328). Exilado em Kursk, após alguns meses, em 18 de novembro de 1932, conseguiu retornar a Leningrado $^{100}$.

\footnotetext{
97 “Случай” (Slutchai).

98 "Cmapyxa" (Starukha).

${ }^{99}$ Depois da prisão de Kharms, em 1941, sua esposa Marina Málitch entrega seus escritos para um amigo o escritor a fim de salvar a antologia do marido.

${ }^{100}$ Sua segunda esposa, Marina Málitch, relata, anos mais tarde, que a prisão foi um evento extremamente danoso para a personalidade de Kharms. (Glotser, 2000)
} 
Ao longo da década de 1930, o escritor sobrevive das poesias e contos que escreve para crianças, mas as duras condições de vida na, então, URSS stalinista, impunham-lhe grandes privações. Em seus diários, há relatos de que ele e a esposa ${ }^{101}$, em muitos momentos, passavam fome.

Conforme relata Marina Málitch, num livro onde conta suas memórias do tempo em que foi casada com Kharms: "Nós vivíamos só com aquele dinheiro, daqueles honorários que Dánia ${ }^{102}$ recebia. Quando ele recebia, quando lhe pagavam, nós comíamos. Vivíamos sempre famintos. Com frequência acontecia de não haver nada para comer, absolutamente nada". (Glotser, 2000, p. 85).

Curiosamente, o tema da fome, da caçada e da busca por alimentos é recorrente nas histórias e poesias escritas para crianças.

E, em 1937, devido a um poema escrito para crianças, em pleno início dos expurgos stalinistas, o escritor volta a enfrentar problemas com a crítica partidária, fato que torna mais difícil ainda a aceitação de seus trabalhos em publicações:

\section{Um homem saiu de casa}

Um homem saiu de casa

porrete e um saco a carregar, e longo caminho, e longo caminho pôs-se a trilhar.

Seguia direto e em frente e para frente olhava, nem dormia, nem bebia, nem bebia, nem dormia, nem dormia, nem bebia, nem comia.

Eis que um dia de madrugada entrou numa floresta escura e, desde então, e, desde então, desde então sumiu.

Mas, se por acaso,

\footnotetext{
${ }^{101}$ Em 1934, Kharms já estava separado de Russakova e casa-se com Marina Málitch.

102 Hipocorístico de Daniil.
} 
você com ele se encontrar,

depressinha,

depressinha,

venha nos contar ${ }^{103}$.

Ao trazer como personagem um homem que sai de casa e não volta, o poema remetia a um fato corriqueiro na ditadura de Stálin, que era o desaparecimento de pessoas consideradas inimigas do povo ${ }^{104}$. Os versos soaram como uma afronta ao governo soviético e o escritor voltou a ter os olhos do Partido voltados para si. A redação da revista foi, inclusive, aconselhada a não mais publicar as obras de Kharms.

Em 1941, é declarada a guerra entre URSS e Alemanha, dois meses após o início do conflito, Kharms, já com sua saúde física e mental bastante fragilizadas, foi preso em 23 de agosto sob acusação de agitação derrotista. O país vivia tempos de fome e a cidade começaria em breve a ser evacuada, devido à aproximação do exército alemão.

No ano seguinte, mantido numa prisão psiquiátrica de Leningrado, ele seria dado como morto, em 2 de fevereiro 1942, num momento em que as tropas nazistas já cercavam a cidade. Sua mulher, Marina Málitch, não possuindo mais família e sabendo da morte do marido, consegue deixar a cidade num dos últimos caminhões de evacuação. Os materiais de Kharms, incluindo uma mala com todos os seus trabalhos, foram por ela deixados com o amigo Iákov Drúskin.

\subsection{A obra kharmisiana: trajetória das publicações.}

Traçaremos a seguir o percurso de criação literária de Daniil Kharms a partir de sua estreia na década de 1920; citando trabalhos publicados em vida e obras não lançadas pelo autor. Dessa forma, evidenciaremos que parte de sua obra permaneceu desconhecida do público durante os anos mais endurecidos do período soviético, justamente porque

\footnotetext{
103 Tradução do poema “Из дома вышел человек”. (In: Kharms, 2011, p. 69)

${ }^{104}$ Alguns anos depois o próprio Kharms representaria esse papel. Sendo preso em agosto 1941, em plena Guerra Patriótica, por "agitação derrotista", foi levado para o um hospital psiquiátrico onde veio a falecer em 2 de fevereiro do ano seguinte, vítima do cenário de miséria que assolava Leningrado.
} 
passou por percalços que fizeram com que ela só se tornasse acessível aos leitores anos após ter sido escrita.

Em virtude de seu falecimento em 1942, sua produção caiu no esquecimento, sendo apagada da memória do cidadão soviético. Embora Kharms tenha colaborado regularmente com duas publicações mensais destinadas ao público infantil, teve seu nome de escritor apagado, não possuindo sequer um verbete em nenhuma enciclopédia soviética no período stalinista (1924 - 1953).

Somente vinte anos depois, a partir da década de 1960 e em decorrência de uma leve abertura cultural na política soviética, começa o processo de reabilitação de sua produção, juntamente com vários outros artistas proibidos durante o período stalinista.

O início dessas tiragens ocorreu entre os anos de 1926 e 1927. Após um ano de apresentações públicas nas quais Kharms recitava suas poesias, ele publica o poema "Incidente na estrada de ferro"105 na Coletânea de Poemas da União de Poetas de todas as Rússias ${ }^{106}$ e, no ano seguinte, "O verso de Piotr-Iachkin, o comunista"107, que sai pela antologia Kostior (A fogueira) ${ }^{108}$, da União dos Poetas de Leningrado.

Nesse momento, o artista e seu grupo ainda não haviam concebido o nome OBERIU, mas através da parceria com o poeta e amigo, também tchinary, A. Vvedénski escreve para o teatro de vanguarda Radiks a peça Mamãe de Sentinela ${ }^{109}$ que não chegou a ser encenada, nem publicada, devido à falta de patrocínio e complicações políticas.

\footnotetext{
105 “Случай на железной дороге”.

106 Собрание стихотворении, Ленинградское отделение Всероссийский союз поэтов (Sobránie stikhotvorénie, Leningrádskoie otdelenie Vserossiski soiuz poetov).

107 “Стих Пётра-Яшкина — коммуниста".

108 Костёр.

109 "Моя мама вся в часах".
} 
Após a estreia da OBERIU, o grupo teve as atividades reprimidas pelo governo soviético e, apesar de Kharms ter continuado a produzir um volume considerável de trabalhos, escritos nos moldes pensados pelos oberiúty, não havia perspectivas de veiculálos. Em decorrência da censura, parte considerável da obra kharmisiana permaneceu sob o formato de manuscrito.

Após 1927, o escritor consegue, ao menos, compor e divulgar uma série destinada ao público infantil, gênero ao qual sua produção passou a estar vinculada. Assim, Kharms logrou publicar obras que estivessem de acordo com a proposta das editoras, à época, para a LIJ soviética. As principais revistas para as quais contribuiu foram $I o j$ - em português O ouriço ${ }^{110}$ — publicada entre 1928 e 1935 e Tchij — O pintassilgo ${ }^{111}$ — publicada entre 1930 e 1941.

É importante nos determos nas revistas Ioj e Tchij, pois sua configuração, que lembrava bastante nossos atuais almanaques infantis, influenciava na formatação das histórias nelas publicadas, bem como na interação do escritor com o público. Apresentavam o formato brochura e, à época, a primeira tinha como público alvo os Pioneiros ${ }^{112}$, enquanto a segunda visava à expansão do conjunto de seus leitores e continha trabalhos dedicados às crianças de menos idade.

Ambas de publicação mensal e circulação em Leningrado, além de conter textos de gêneros variados, reproduziam caricaturas, ilustrações, adivinhas, cartas dos leitores

\footnotetext{
$110 \mathrm{O}$ nome da revista - ËÆ - além de se referir ao nome do animal também é a abreviatura de "Ежемесячный журнал" (Iejmíciatchni Jornal), que significa "Revista Mensal".

${ }^{111} \mathrm{O}$ nome completo dessa revista era "Чрезвычайно Интересный Журнал" (Tcheresvitcháino interiésni jurnal), que podemos traduzir como "Uma revista extremamente interessante". A abreviatura, Чиж, forma o nome do pássaro, pintassilgo.

${ }^{112}$ Instituição soviética para crianças entre 10 e 15 anos, cuja marca registrada era o uso de lenço vermelho em torno do pescoço. Os Pioneiros guardavam semelhanças com o Movimento dos escoteiros, mas possuíam seu próprio código de condutas e faziam votos de honrar tanto os preceitos leninistas, quanto as causas do Partido Comunista. Seus integrantes eram engajados em atividades que contribuíssem com a comunidade, mas também recebiam incentivo para a prática de esportes e atividades coletivas.
} 
etc. Listaremos, a seguir, as principais publicações dessas e de outras revistas em ordem cronológica:

Em 1928, um ano após a estreia de Kharms como escritor de literatura infantil, saem pela revista Ioj os poemas "Iván Iványtch, o samovar"113, "Iván Taporýchkin"114, “As aventuras do ouriço"115, "Por que está feliz, Vânia?"116 e "Por que?"117. Também são publicadas as histórias, por nós aqui traduzidas, "O fusível travesso"118, "De como Kolka Pánkin voou para o Brasil e Pietka Erchov não acreditou em nada"119 "17 cavalos"120, "Em primeiro e em segundo lugar" $" 121$ e "Como a velhinha comprava tinta"122. O período foi produtivo para Kharms.

Contudo, as dificuldades políticas daquele momento faziam com que o número de obras publicadas variasse de um ano para outro. Em 1929, ele publica apenas três poemas: “Como papai matou um furão para mim"123, "Quem de vocês leu"124 e "Ga-ra-rar!”125. No ano seguinte, 1930, ocorre o lançamento de Tchij que conta com o poema "Os pintassilgos alegres"126; em Ioj lança "O mentiroso"127 e a história "Um atrás do outro"128.

Figura 1: Capa da primeira edição de Tchij.

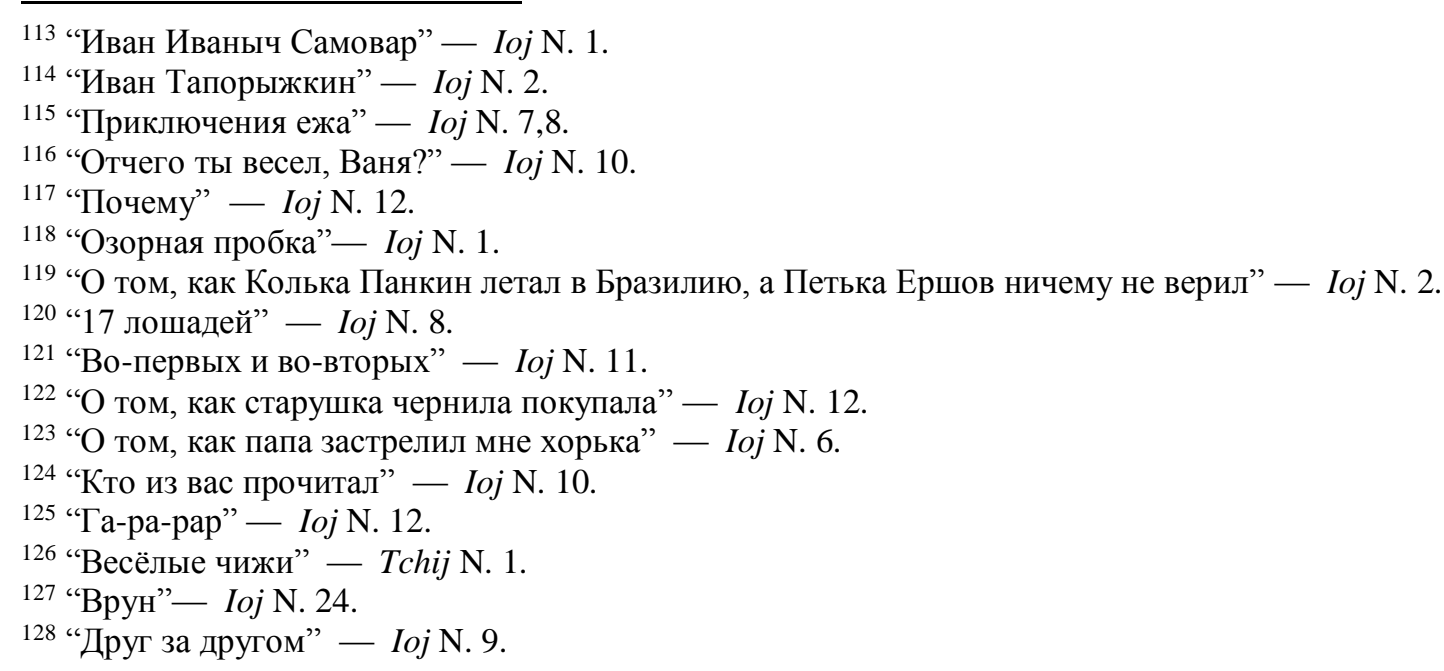




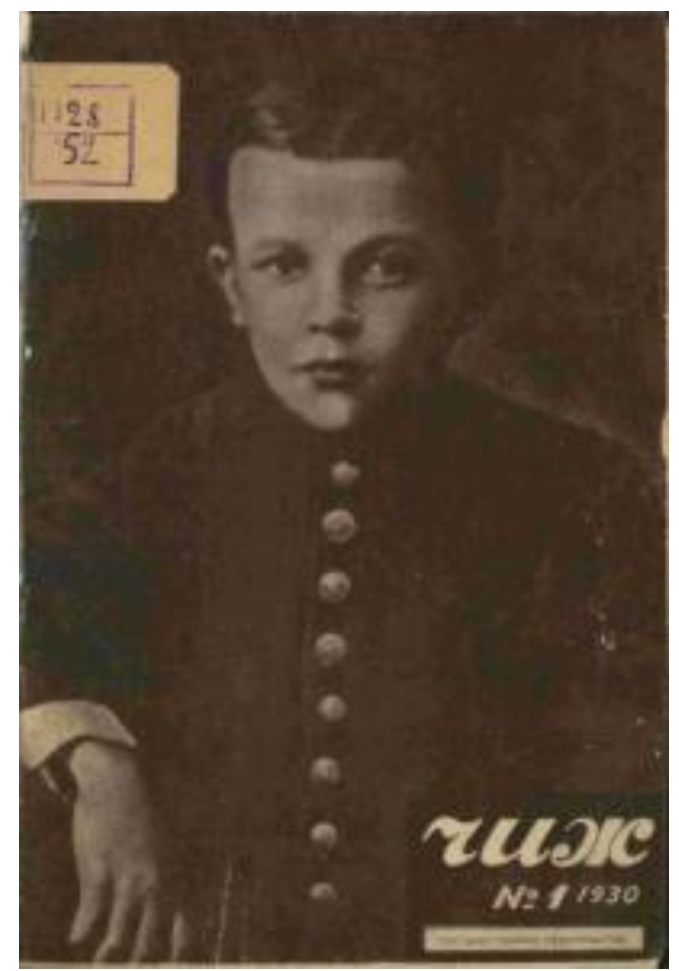

(Fonte: www.journal-club.ru. Acesso Dez. 2014)

No ano de 1931, há registro do poema "O que vamos cozinhar para o inverno"129. Nesse momento, a prisão de Kharms aumentou as barreiras já existentes em seu trabalho de escritor, tornando mais difícil a publicação de suas obras, que só voltam a ter edições dois anos depois. Em 1933, ainda abalado pelos onze meses de exílio, Kharms torna a escrever e compõe a série "O professor Trúbotchkin""130; no ano seguinte, 1934, "De como Macha fez o burro levá-la à cidade"131, ambas publicadas em Tchij. Em 1935, os poemas "Kryssakóv e dois cachorros"132, "A nova cidade"133, "O que significa isso?"134 e as histórias "Os sete gatos"135, "Um conto maravilhoso"136, "Sobre o cachorro Bububu"137

\footnotetext{
129 “Что мы заготовляем на зиму” - Ioj N. $19-20$.

130 "Профессор Трубочкин" — Tchij N. 7, 8, 11 е 12.

131 “Как Маша заставила осла везти ее в город” — Tchij N. 2.

132 “Крысаков и две собачки” - Tchij N. 3, 4.

133 “Новый город” - Тchij N. 5.

134 “Что это значит?” — Tchij N. 12.

135 “Семь кошек”- Tchij N. 1.

136 “Сказка" - Tchij N. 7.

137 "Про собаку Бубубу” — Tchij N. 78.
} 
e "O ouriço valente" 138 saem em Tchij. Paralelamente, Kharms dedicava-se à série Incidentes (1933 - 1939), publicada anos depois, apenas após sua reabilitação.

Kharms também dedicou-se à tradução de alguns de seus escritores prediletos, um deles foi alemão Wilhelm Busch, de quem traduziu para o russo as obras: "Plikh e Pliukh"139 — originalmente "Plisch und Plum" — e "Como Volódia rapidamente voou montanha abaixo"140 — em alemão, "Die Rutschpartie". Ambas publicadas no ano de 1936, apresentavam um estilo de tradução bastante livre, de modo que as versões russas constituem-se em recontos criativos dos textos originais. As poesias "Um tigre na rua"141 e "Hoje vamos correndo à escola"142 são do mesmo período.

Por vezes, a Revista Tchij é citada no contexto de alguma história: "Envio-lhes meu retrato. Publiquem-no na capa da revista Tchij número 7" — em "O professor Trúbotchkin"; "O quadro era tão bem feito que decidimos publicá-lo na Revista Tchij, número 1, de 1936" (p.) — em Sobre o cachorro Bububu; "Vânia comprou Tchij, n. 7, e daí leu esta mesma estória que você acabou de ler” (p.) — em Um conto maravilhoso.

Essa retomada, no corpo das histórias, dos nomes das revistas que as publicava ajudava a atrair a atenção dos leitores e funcionava enquanto estratégia de propaganda para que novos números fossem adquiridos. Podemos perceber, inclusive, que esse tipo de apelo se intensifica a partir de 1934.

Cabe lembrarmos que as revistas infantis precisavam ser atrativas para as crianças, por isso, tanto os poemas, quanto os contos continham ilustrações, num formato que lembra nossas atuais histórias em quadrinhos. Porém, o teor político e a adequação

\footnotetext{
138 “Храбрый Ёж”- Tchij N. 12.

139 “Плих и Плюх" — Tchij N. 8-12.

140 “Как Володя быстро под гору летел” — Tchij N. 12.

141 “Тигр на улице" — Tchij N. 5.

142 “Мы спешим сегодня в школу” — Tchij N. 8.
} 
ideológica aos preceitos governamentais eram determinantes para que as obras pudessem ser divulgadas.

Em 1937, a partir da publicação do poema "Um homem saiu de casa"143, Kharms voltou a ser alvo das críticas partidárias e a redação da revista Tchij foi aconselhada a não mais publicar seus trabalhos (Kharms, 2011, p. 281). Nesse mesmo ano, o poema "Os gatos" ${ }^{144}$ sai pela revista Svertchók (O grilo) e não há registro de outras publicações do escritor.

Em 1938, a revista Tchij edita uma série dos poemas de Leib Kvitko ${ }^{145}$, com traduções de Marchák e Zabolótski, entre outros; Kharms voltou à ativa e foi responsável por traduzir "O combatente"146. São desse ano, da mesma forma, os poemas "Esse intrépido cavalinho"147, "Uma história espantosa"148, "O jogo"149, "Versinho"150, "Sou o mais valente"151, "O gato surpreendente"152, "Em visita" 153 e "Canção sobre o guarda da fronteira" ${ }^{" 154}$.

Figura 2: Página da Revista Tchij com poema “O gato surpreendente”, de Kharms e ilustrações de N. Radlov.

\footnotetext{
143 “Из дома вышел человек” - Tchij N. 3.

144 “Кошки”- - Svertchók N. 4.

145 Poeta judeu vinculado ao Partido comunista. Escreveu poemas em russo e iídiche, gozava de popularidade na URSS.

146 "Танкист" - Tchij N. 11.

147 “Это резвый конь ребёнок”- Tchij N. 3.

148 “Очень страшная история" - Tchij N. 3.

149 “Игра" — Tchij N. 3.

150 “Считалка" - Tchij N. 10.

151 “Я самый храбрый” — Tchij N. 10.

152 “Удивительная кошка" — Tchij N. 11.

153 "В гостях" - Tchij N. 11.

154 "Песенка про пограничника" — Tchij N. 12.
} 


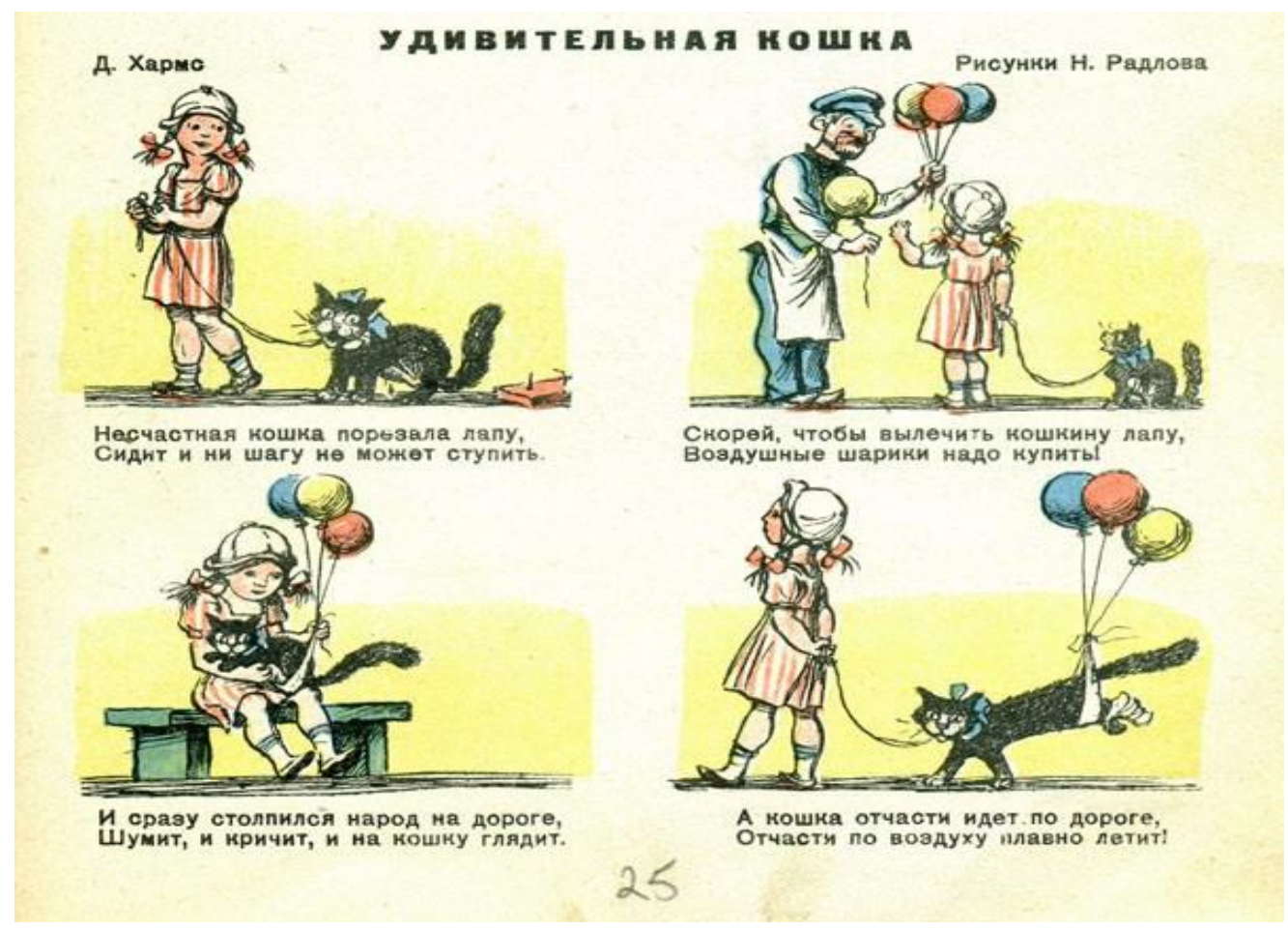

(Fonte: www.zavjazhu.livejournal.com. Acesso em Dez. 2014)

A partir de então, há um momento de recrudescimento da censura e das perseguições políticas. Dentro do país, Stálin intensificava a luta contra os inimigos do povo e, nas relações internacionais, a URSS pressentia a aproximação da guerra. O poema “Canção do Primeiro de Maio"155, publicado em 1939, alude abertamente à essa ambiência:

(...) Para gritar à toda terra,

Muitas, muitas vezes:

Não há inimigo em toda a terra, em toda a terra,

Não há inimigo em toda a terra

temido por nós.

Porque se o inimigo,

se o inimigo,

Porque se o inimigo

De súbito atacar

Vorochilov ${ }^{156}$ a cavalo,

\footnotetext{
155 Tradução do poema "Первомайская песня" - Tchij N. 4; (In: Kharms, 2011, p. 78). O poema alude tanto à aproximação da guerra contra a Alemanha, quanto à exposição realizada em 1 de maio de 1922 pela Associação de Artistas Revolucionários da Rússia. Tal evento chamado de "Exposição de pinturas para ajudar vítimas da fome" recebeu patrocínio de Vorochilov, então líder do Exército Vermelho.

${ }^{156}$ Militar; comandou as tropas soviéticas na guerra contra a Finlândia (1939 - 1940).
} 
a cavalo,

Vorochilov a cavalo

à batalha nos conduzirá.

Em 1939, também lança os poemas "O buldogue e o dachshund"157, "Cegonhas e barcos" $" 158$ e "O violinista alegre" $" 159$. Em 1940, encontramos os registros dos últimos trabalhos que Kharms publicou em vida, são eles os poemas “O porteiro Papai Noel” ${ }^{160}$, "O que foi aquilo?"161, "Procurava uma velhinha joaninhas nas flores"162, "O barquinho"163, "O velhinho alegre"164 e "O estranho barbudo"165.

A partir de 1941, Kharms já não consegue publicar mais nenhum trabalho. Despontava a chamada Guerra Patriótica. Devido à invasão alemã ao território soviético, os cidadãos de Leningrado passaram a conviver com a fome e com as penúrias da guerra. Kharms, debilitado e doente, é dado como mentalmente incapaz pelas autoridades soviéticas, livrando-se do recrutamento pelo exército, mas não da prisão.

Após sua morte, em 1942, seus manuscritos são mantidos sigilosamente por Iákov Drúskin por mais de vinte anos. Não era de interesse do governo soviético a divulgação de estéticas consideradas subversivas e não adequadas ao Realismo Socialista, muito pelo contrário, as políticas culturais reprimiam essas manifestações artísticas. Assim, nesse intervalo, as editoras soviéticas deixam de publicar obras dos oberiúty, cujo trabalho de vanguarda é esquecido.

\footnotetext{
157 “Булдог и таксик" - Tchij N. 5. Dashhund é uma raça de cachorro oriundo da Alemanha. No Brasil, os cães dessa raça são, por vezes, popularmente chamados de "bassê".

158 “Журавли и корабли” - Tchij N. 7 е 8.

159 “Весёлый скрипач" - Tchij N. 9.

160 “Дворник - Дед Мороз” - Tchij N. 1.

161 “Что это было?"- Tchij N. 3.

162 “Искала старушка букашек в цветах" - Tchij N. 4.

163 "Кораблик" - Tchij N. 5.

164 “Весёлый старичок" - Tchij N. 6.

165 “Странный бородач" - Tchij N. 10.
} 
Apenas no final da década de 1950, após a morte de Stálin, a política cultural soviética confere alguma abertura para a publicação de obras que não fizessem parte do Realismo Socialista. Durante esse período, o chamado Degelo (1956 - 1964), a recuperação das obras desses escritores, antes proibidos, ocorria de forma lenta e gradativa, em publicações esparsas, com baixas tiragens. Nesse momento, Drúskin ousa revelar estar em posse dos materiais pertencentes ao amigo Kharms; tendo-os guardado e protegido nesse hiato de tempo. Desse modo, enfim, os arquivos do escritor são abertos.

Progressivamente, na década de 1960, leitores soviéticos começam a ter acesso às obras que Kharms escrevera, estando as publicações para crianças aí incluídas. Em 1961, a enciclopédia Escritores soviéticos de literatura infantil: dicionário bibliográfico ${ }^{166}$ faz um apanhado das obras que ele publicou entre 1920 e 1940. No ano seguinte, uma coletânea soviética de histórias infantis selecionadas, publicada em Moscou, incluía o poema “O jogo"; em 1967, essa coletânea continha "O que foi aquilo?”.

Em 1965, a antologia Dia da poesia" ${ }^{167}$ trazia os poemas "Maria sai fazendo reverência...” e "A amiga"168. Em 1967, o Jornal Literário, n.47, ${ }^{169}$ publicava “Anedotas da vida de Púchkin", "Fardo" e "Conto maravilhoso"170. Os números 46 (1968), 27 (1970) e 31 (1973) desse mesmo jornal publicam respectivamente "Uma peça" e "Sinfonia N. 2"171; “A conexão" e "Uma fábula"172; “A carta"173.

\footnotetext{
${ }^{166}$ Детский Советский Писатели: библиографический словарь. (Dietski Sovietski pissateli: bibliografitcheski slovar). cf. George Gibian.

167 День поэзии (Dien poesii).

168 “Выходит Мария отвесив поклон...”; “Подруга".

169 Литературная газета (Literaturnaia gazeta).

170 “Анегдоты из жизни Пушкина”; “Тюк”; “Сказка”.

171 "Пиеса"; "Синфония №. 2".

172 “Связь”; "Басня".

173 "Письмо".
} 
A revista de literatura e arte Grani (Grãos) $)^{174}$ (editada na Alemanha) publicou contos e poemas de Kharms, bem como, o "Manifesto OBERIU”, no exemplar número 81. A publicação de textos inéditos e a tradução de obras suas no exterior marcam uma redescoberta da literatura kharmisiana não só pelos seus conterrâneos, mas também fora da Rússia.

As publicações pós-Degelo forneceram material ao professor da Cornell University, George Gibian, que na década de 1970 traduziu para o inglês os materiais disponíveis da obra de Kharms. Suas traduções são editadas e publicadas, em 1974, simultaneamente nos Estados Unidos e no Canadá. Então, fora da União Soviética, não levou muito tempo para que Kharms caísse no gosto do público e da crítica pela sua originalidade e irreverência.

Depois da década de 1970, os trabalhos do recém (re)descoberto Daniil Kharms são traduzidos para o polonês (Varsóvia), tcheco (Praga), alemão (Frankfurt) e inglês. Em 1977 e 1978, uma antologia ${ }^{175}$ foi publicada em Bremen com comentário e organização de Mikhail Meilakh ${ }^{176}$ e Vladimir $\operatorname{Erl}^{177}$.

Durante os períodos da Perestroika e da Glasnost, após 1986, vêm à luz novas edições da obra kharmisiana em território soviético, resultado de uma pesquisa de materiais do autor arquivados na Casa de Púchkin ${ }^{178}$. Em 1987, a tradicional revista infantil Murzilka ${ }^{179}$ trazia o conto "Púchkin". 180

\footnotetext{
${ }^{174}$ Грани.

175 Хармс Д. Собрание произведений. под ред. М. Мейлаха и Вл. Эрля. Bremen: K-Presse, 1978.

${ }^{176}$ Crítico literário, autor de artigos sobre a obra de Anna Akhmatova, além de editor das obras de Kharms e Aleksandr Vvedenski, na Alemanha.

${ }^{177}$ Poeta e prosaísta.

178 Пушкинский Дом. (Puchkinski Dom). A Casa de Púchkin é um instituto de referência em pesquisa e ensino de literatura. Possui amplo acervo, incluindo documentos pessoais e manuscritos de importantes escritores russos.

${ }^{179}$ Мурзилка.

180 cf. Sobranii sotchinenii v triox tomakh. (2011).
} 
Em 1988, sai mais uma coletânea: Daniil Kharms. Voo ao céu: Poemas. Prosa. Drama. Cartas. ${ }^{181}$; prefaciada e comentada por A. Aleksandrov. Em 1991, Aleksandr Kobrinski e Andriei Ustinov publicam a coletânea Kharms D. I. A garganta delira com a navalha: Incidentes, contos e diários ${ }^{182}$; tal obra conta com prefácio e comentários dos organizadores. Nesse mesmo ano, a novela $A$ velha ${ }^{183}$ é publicada em obra organizada por Vladimir Glotser ${ }^{184}$.

O interesse pelo autor não é arrefecido após o fim da URSS e, em 1995, surge Dannil Kharms e o fim da vanguarda russa ${ }^{185}$ de Jean-Phillipe Jaccard, em São Petersburgo. A primeira edição das obras completas reunidas ${ }^{186}$ de Daniil Kharms deu-se somente entre 1997 e 1998 em São Petersburgo, com organização de Valiéri N. Sájin ${ }^{187}$. Enfim, notamos um período de mais de trinta anos entre o início do processo de reabilitação do escritor e a definitiva publicação de suas obras completas.

Quando os arquivos do escritor começaram a tomar caráter público, a produção dos oberiúty também passou a atrair a atenção de pesquisadores e críticos literários dispostos a se debruçar sobre o conjunto de sua obra que, com efeito, recebe gradativamente edições mais completas contendo, não apenas os textos literários, mas também seus diários, textos filosóficos etc.

Em nosso país, o professor e tradutor de literatura russa, Boris Schnaiderman, foi quem primeiramente voltou-se para a obra de Kharms ao traduzir para a Revista USP, em

\footnotetext{
181 Хармс Д. Полёт в небеса : Стихи. Проза. Драмы. Письма. подгот. текста и примеч. А. Александрова. Ленинград: Сов. писатель, 1988.

182 Хармс Д. И. Горло бредит бритвою: Случаи, рассказы, дневниковые записи. Сост. и комм. А.Кобринского и А.Устинова. Москва.: Глагол, 1991.

${ }^{183}$ Хармс Д. Старуха : Рассказы. Сцены. сост. В. Глоцер. Моска: Юнона, 1991.

${ }^{184}$ Pesquisador e crítico literário.

185 Даниил Хармс и конеи русская авангарда. (Daniil Kharms i konets russkaia avangarda).

${ }^{186}$ Segundo a enciclopédia Escritores russos do século XX: dicionário biográfico - Русские писатели 20 века: биографический словарь. (Ruskie pissateli 20 veka: biografitcheski slovar). (2000, p. 724 - 725)

187 Хармс Д. Полное собрание сочинений : в 4 томах. под ред. В. Н. Сажина. СПб. : Академический проект, 1997.
} 
1991, um conto da série Incidentes ${ }^{188}$, chamado "O Baú"189. O pesquisador utilizou como fonte o texto original presente na coletânea Ízbranoie (Obras escolhidas), organizada por George Gibian e publicada em 1974 na Alemanha. Schnaiderman também escreveu um artigo intitulado "Escritor russo antecipou o absurdo de Beckett e Ionesco", publicado no Jornal “O povo” em 19 de julho de 1995.

Em 2001, Sheila Oliveira Lima apresenta a dissertação 'A velha' uma representação intertextual do absurdo, sob a orientação de Homero Freitas de Andrade. A pesquisadora traduz pela primeira vez para o português brasileiro uma das obras mais importantes da produção kharmisiana, apresentando a análise dos procedimentos intertextuais que o escritor lançou mão para a construção de um "discurso múltiplo".

Em 2013, ocorre o lançamento de mais uma obra dedicada a Kharms, no Brasil: 'Os sonhos teus vão acabar contigo': prosa, poesia, teatro, com tradução de Daniela Mountian, Moissei Mountian e Aurora Fornoni Bernardini.

O interesse pela obra do escritor tem aos poucos crescido entre tradutores e pesquisadores brasileiros, mas ainda há lacunas no que se refere a um estudo mais amplo de sua obra, sobretudo quando pensamos no conjunto de suas histórias infantis, ainda pouco conhecidas e analisadas. Coletânea representativa da proposta literária Kharmisiana, não apenas por conter os mesmos procedimentos experimentais dos oberiúty, mas também, por terem sido, em conjunto com as poesias infantis, a única parcela de sua produção que o escritor conseguiu publicar em um momento de forte censura e repressão política, na URSS.

\footnotetext{
${ }^{188}$ Случай (Slutchai). Kharms, D. “O baú”. Trad. de Boris Schnaiderman. In: Revista USP, n. 10, São Paulo, Edusp, 1991.

189 “Сундук”.
} 


\title{
3. As raízes da literatura infantil e as diretrizes soviéticas para o gênero
}

\subsection{A gênese da Literatura Infantojuvenil (LIJ)}

\author{
"A Literatura Infantil é, antes de tudo, literatura; ou melhor, é \\ arte: fenômeno de criatividade que representa o Mundo, o Homem, \\ a Vida, através da palavra."
}

(Nelly Novaes Coelho, 2000, p. 24)

O estabelecimento da literatura infantil como gênero literário específico, na Idade Moderna, deu-se no período de ascensão da burguesia, juntamente com a institucionalização do conceito de "infância”. Após o século XVII, mudanças na estrutura econômico-social passaram a separar o mundo do trabalho do familiar, os acontecimentos do âmbito coletivo daqueles da vida doméstica, o universo dos adultos e o das crianças. Era o início da configuração daquilo que chamamos, hoje, de família burguesa e, junto com ela, delineava-se também a noção de infância que perdura até nossos dias.

Na sociedade antiga, não havia a "infância": nenhum espaço separado do "mundo adulto". As crianças trabalhavam e viviam junto com os adultos, testemunhavam os processos naturais da existência (nascimento, doença, morte), participavam junto deles da vida pública (política), nas festas, guerras, audiências, execuções etc.; tendo assim seu lugar assegurado nas tradições culturais comuns: na narração de histórias, nos cantos, nos jogos. (RICHTER, D. apud ZILBERMAN, R., 1985, p. 44)

A criança, separada do universo adulto em seu cotidiano de trabalho, deixa de apreender a cultura de seus antepassados de modo quase que espontâneo, como ocorria entre camponeses e artesãos, por exemplo, passando doravante a requerer atenção especial quanto à educação. A infância passa a ser vista como uma fase preparatória para a vida adulta e a criança não é mais uma miniatura inacabada, como acreditava-se na sociedade medieval, mas um indivíduo em formação. Nesse contexto de ressignificação histórica dos primeiros anos da vida humana, nasce também o que chamamos hoje de literatura infantil, enquanto um poderoso instrumento educacional. 
Atualmente, ao analisarmos as obras que desde então têm mantido seu poder de atração sobre as crianças de todas as épocas e classes sociais, podemos nelas perceber traços herdados da história literária universal, das narrativas primordiais até as tendências mais atuais. Contudo, é importante considerarmos que as narrativas folclóricas do fantástico-maravilhoso ${ }^{190}$ ajudaram no fornecimento de bases importantes para esse novo gênero, de modo que, atualmente, já não podemos falar dos contos de fadas e fábulas sem buscarmos suas interligações com a LIJ.

Longos caminhos percorreram as narrativas ancestrais, oriundas de diversas localidades do globo, até transformarem-se em folclore e, posteriormente, nos contos de fadas da literatura para crianças.

Para construir um acervo de obras adequadas à educação dessa criança, a pedagogia dos séculos XVII e XVIII lança mão, num primeiro momento, dos contos maravilhosos de tradição oral ${ }^{191}$ e, posteriormente, de histórias clássicas da literatura universal que, após serem adaptadas ao gosto e compreensão infantis, pudessem transmitir aos pequenos os conhecimentos sociais, morais e comportamentais vigentes naquele momento. $\mathrm{O}$ caráter didático dos textos era fundamental para seu ingresso nesse rol. Assim, desde sua gênese, o gênero assume a função de auxiliar no processo educativo. Daí provém uma de suas funções intrínsecas até a atualidade: educar.

\footnotetext{
${ }^{190}$ As narrativas do fantástico-maravilhoso podem ser divididas, em contos de fadas (conto maravilhoso onde as fadas aparecem); contos de encantamento (histórias que apresentam metamorfose ou transformação); contos maravilhosos (estórias que apresentam o elemento mágico integrado às situações apresentadas); fábulas (vividas por animais); lendas (estórias ligadas à origem dos tempos ou de uma comunidade, em que figuram o elemento mágico); contos de enigma ou mistério (em que o eixo encontrase num enigma a ser desvendado); e contos jocosos (humorísticos, divertidos etc). cf. Coelho, N. N., 1991, p. 142 - 143. Todas essas categorias são popularmente conhecidas, entretanto, como "contos de fadas", mesmo que não contenham fadas entre suas personagens.

${ }^{191}$ Os contos folclóricos, transmitidos oralmente entre as gerações, foram coletados e popularizados literariamente.
} 
Em termos estéticos, a literatura infantil precisava acoplar elementos de ludicidade (jogos linguísticos, rimas, onomatopeias, criação de palavras, chistes etc), sem os quais as narrativas deixariam de conseguir o efeito desejado junto ao ouvinte/leitor tão ligado ao universo da brincadeira. Por isso, é através das exigências intrínsecas ao modo de aprender desse público leitor peculiar que a literatura escrita para os pequenos assume outra de suas funções centrais: divertir. "Compreende-se, pois, que essas duas atitudes polares (literária e pedagógica) não são gratuitas. Resultam da indissolubilidade que existe entre a intenção artística e a intenção educativa incorporadas nas próprias raízes da Literatura Infantil.” (COELHO, N. N., 2000, p. 43)

As narrativas da tradição oral tiveram prioridade nesse processo educativo, por isso passaram a receber tratamento textual literário, sendo compiladas em versões infantis. Tais histórias, que haviam pertencido durante séculos no âmbito do folclore ${ }^{192}$, acumulavam em si uma gama de conhecimentos transmitidos por hábeis contadores de história que, provavelmente, aproveitavam-se dos dias de frio intenso para, ao pé da lareira, do fogão ou em volta de uma fogueira, contarem aos mais jovens as histórias aprendidas com os mais velhos. "Nas primeiras idades do mundo, como é sabido, os homens não escreviam. Conservavam suas lembranças na tradição oral; onde a memória falhava, entrava a imaginação para supri-la e a imaginação era o que povoava de seres o seu mundo”. (SOSA, J., p. 106)

Muitos estudiosos procuraram compreender porque o conto popular, uma vez adaptado, calhou tão bem ao gosto infantil. Uma das possíveis respostas para esse questionamento seria o fato da mentalidade dos pequenos, em sua forma de apreender o mundo que a circunda, estar próxima da do homem primitivo. Hipótese com a qual

192 A particularidade, de fato, distintiva do folclore, em relação à literatura reside na forma oral. cf. AMÉRICO, E. V., 2006, p. 17 - 18. 
concordamos, à medida em que não enseje preconceito acerca dos modos empregados pela criança e pelo povo para lidarem com a realidade.

Sabemos que a criança ainda não dispõe do pensamento abstrato, utilizado na linguagem filosófica, para lidar com os fenômenos da natureza e da sociedade. Assim, sua forma de compreensão envolve o levantamento de hipóteses sobre objetos de seu interesse e a percepção do funcionamento das coisas através das experiências concretas. Entretanto, tal característica própria da fase não diminui, a nosso ver, a riqueza existente no universo infantil.

Em outras palavras, no povo (ou no homem primitivo) e na criança, o Conhecimento da realidade se dá através do sensivel, do emotivo, da intuição... e não através do racional ou da inteligência intelectiva, como acontece com a mente adulta e culta. Em ambos predomina o pensamento mágico, com sua lógica própria. Daí que o popular e o infantil se sintam atraídos pelas mesmas realidades. (COELHO, N. N., 2000, p. 36)

Dessa forma, ao passo que os pequenos não possuem uma visão global da sociedade onde estão inseridos, o conto de fadas sintetiza um modelo em miniatura da sociedade: um mundo em si, repleto de personagens-tipo, onde a melhoria nas condições de vida do herói ou qualquer tipo de mobilidade social ocorrem por meio da magia e do maravilhoso. "A atração do conto folclórico para a criança reside, como afirmamos, além de outros aspectos, na elaboração de um esboço compreensível da sociedade" (RICHTER, D. et. ali. apud ZILBERMAN, R., 1985, p. 46)

Os portadores dessa tradição oral eram, em geral, pessoas pertencentes às camadas mais pobres; empregados que entravam à casa dos mais ricos pelas portas dos fundos e exerciam suas funções longe dos salões nobres e salas de visitas. Muitas vezes, as babás 
eram responsáveis por comunicar aos filhos da burguesia as ricas histórias de tradição $\operatorname{popular}^{193}$.

Originalmente, os contos folclóricos não possuíam a criança como destinatário, mas condensavam a visão de mundo e as experiências dos povos em narrativas cuja crueza não poupava os ouvidos inocentes dos mais novos. Portanto, muito antes de usar capuz vermelho, a menina mais conhecida dos contos maravilhosos se despia em frente ao lobo para, depois, ser devorada de vez; enquanto a bela adormecida, por seu turno, era molestada em sono profundo pelo companheiro, vindo a despertar somente ao sentir as dores do parto; já Annette, ancestral Cinderela, não poderia desejar nada melhor da fada madrinha do que uma mesa cheia de comida, naqueles tempos de fome. 194 "A violência e a crueldade desses contos medievais, ao serem adaptados para crianças, por Perrault e pelos Grimm, foram 'suavizadas', isto é, expurgadas da grande carga de violência dos textos ancestrais". (COELHO, N. N., 2003, p. 39)

Outro conjunto de histórias que também passou a ocupar lugar na nascente LIJ, sobretudo pela veiculação de uma moral, foi o de fábulas, cujas fontes antigas encontravam-se na Grécia, de Esopo e na Roma, de Fedro. O grande exponente dessa forma é Jean de La Fontaine (1621 - 1695), que juntamente com Charles Perrault ${ }^{195}$ (1628 - 1703), irmãos Grimm (século XIX) e Hans Christian Andersen (1805 - 1875) trabalhou para o estabelecimento do acervo clássico da LIJ. Na Rússia, podemos acrescentar os

\footnotetext{
${ }^{193}$ Podemos citar, como exemplo, o conto "Púchkin", incluído neste trabalho. Baseada em fatos reais, a história deixa claro a importância da babá, Arina Rodiónovna, na formação cultural do grande poeta russo Aleksandr Púchkin. Fora com essa figura, representante do povo, que ele teria aprendido a amar a cultura popular e a língua russas. "O pequeno Púchkin só falava em russo com a avó e com a babá. E foi assim, escutando as histórias e canções da babá, que Púchkin passou a amar a língua russa e começou a escrever poesias em russo." (p.)

194 cf. DARNTON, R., 1988, p. 28 - 53.

${ }^{195}$ Considerado como iniciador da Literatura infantil por fazer as primeiras adaptações de contos folclóricos para crianças, visando seu desenvolvimento moral.
} 
nomes do folclorista Aleksandr Afanássiev ${ }^{196}(1826$ - 1871) e do fabulista Ivan Krylov $(1769-1844)$.

Dada a sua abertura para englobar novas informações, as narrativas de tradição oral foram ganhando novos elementos ao mesmo tempo em que ocupavam o domínio da LIJ, conforme as necessidades da criança, vindo a adquirir, gradualmente, caráter de exemplaridade e simbologia. "No conto de fadas, nada é representado realisticamente, mas de modo figurado; assim, as personagens más não são percebidas como seres vivos, mas como símbolos do mal.” (LUTHI, M. apud ZILBERMAN, R., 1985, p. 47)

Outra característica verificada na transposição do conto folclórico para o conto de fadas infantil diz respeito, especialmente, à permanência do maravilhoso que aparece, muitas vezes "como metáfora emblemática de dados da realidade" ${ }^{197}$, além de ser um fenômeno natural e estruturante do universo extraordinário.

Nesse contexto é que cabe situar o folclore, isto é, o conjunto de manifestações artísticas do povo: danças, cerimônias, canções e, especialmente, manifestações de sua própria imagem, reflexo de suas contradições e de suas crises e, catarticamente, representação de uma solução possível que - não poderia ser de outra forma - se manifestava através da mágica e do elemento maravilhoso. (CADEMARTORI, L., 2010, p. 42)

A criança quando ouve ou lê uma dessas histórias não questiona sua realidade mágica, pois compreende que as leis vigentes nesse "lugar distante" de seu próprio tempo e espaço, pertencem ao âmbito do sobrenatural.

Nesta medida, a magia torna-se um adjuvante do qual a personagem não depende existencialmente, mas que o auxilia a vencer as dificuldades. Além disto, desacreditando as limitações de tempo e espaço, permite uma representação visível, concreta e simultânea de todas as facetas que constituem o universo da criança. (ZILBERMAN, R., 1985, p. 48)

Compreendemos, então, que a história da LIJ consagrou a existência de seres maravilhosos e a ação das forças extraordinárias enquanto itens distintivos das obras que

\footnotetext{
${ }^{196}$ Coletou e publicou diversas narrativas da tradição oral.

197 cf. LIMA, S.O., 2001, p. 102.
} 
tenham a criança como alvo; mesmo daquelas que pretendiam dar ênfase ao real ou ao pedagógico. Desse modo, durante o período Romântico, quando aparece a preocupação de transmitir às crianças histórias que retratassem "a vida realmente vivida pelos homens" (COELHO, N. N., 2000, p. 106). Era a fase do dito realismo maravilhoso ${ }^{198}$ cujas obras passam a mesclar fatos e cenários do cotidiano com os elementos fantásticos; numa fusão que abre caminho para o aparecimento do absurdo e do non-sense, entre outras tendências que se estenderão para o próximo século, como ilustra a obra infantil de Kharms.

Observamos, então, que desde sua origem “o 'maravilhoso' sempre foi e continua sendo um dos elementos mais importantes na literatura destinada às crianças." (COELHO, N. N., 2000, p. 50), fazendo parte de sua tradição independentemente dos temas abordados, da estrutura narrativa empregada ou língua utilizada. No século XX, ele encontra aberturas para refazer-se através do conteúdo cientificista que deu origem à ficção científica com suas experiências, máquinas ultramodernas, surgimento de superhumanos, viagens intergalácticas etc.

Por isso, a magia, as bruxas, as fadas, os reinos, os eventos extraordinários, entre tantas outras quimeras remanescentes de tempos ancestrais, continuam a acompanhar histórias que rompem a barreira do tempo e renovam-se constantemente a partir do olhar sempre novo da criança.

\subsection{A Literatura Infantojuvenil soviética: a busca pelo novo.}

Historicamente falando, antes da revolução de Outubro (1917), o direito à educação era garantido apenas para uma parcela dos russos, assim poucos indivíduos pertencentes aos menos favorecidos da população tinham acesso à escola, para não

\footnotetext{
${ }^{198}$ A LIJ do século XX mostra a continuidade do realismo maravilhoso através de obras ilustrativas: $O$ mágico de Oz (1901), de Frank Baum; Peter Pan (1904), de James Barrier e Reinações de Narizinho (1931), de Monteiro Lobato, entre tantas outras.
} 
mencionarmos outros problemas sociais que, via de regra, castigavam os mais pobres. Um abismo separava as classes instruídas dos camponeses no tocante à instrução formal e praticamente todas as instituições escolares eram propriedade de setores da burguesia ou da igreja. René Capriles (1989, p. 18) esclarece que:

No início do século XX a Rússia era, especialmente no setor da educação, um dos países mais atrasados do mundo. A maioria da população era analfabeta. Os documentos do censo nacional realizado em 1897 demonstram que entre os homens apenas $29 \%$ sabiam ler e escrever, enquanto a porcentagem de mulheres alfabetizadas era muito mais baixa ainda: 13 em cada 100 .

Contudo, após a tomada do poder, os líderes bolcheviques colocam a necessidade de educação dessa população marginalizada como uma das prioridades do novo regime. Dessa maneira, o direito à escola básica e à universidade é estendido a toda a população que, uma vez alfabetizada, aumenta a massa de novos leitores em grandes proporções. Para dar cabo dessa empreitada educativa, a partir desse momento, surge na visão dos intelectuais do Partido, a necessidade de adequação do currículo escolar, das práticas pedagógicas e dos conteúdos culturais às novas demandas sociais do novo regime. Idealizava Trotski (1969, p. 214): “a tarefa cansativa de alimentar e educar as crianças passará da família para a iniciativa pública”.

Através do investimento maciço em educação, ainda durante a guerra civil, o governo pretendia colocar fim ao atraso da velha Rússia elitista e, num curto espaço de tempo, prover a sociedade de mão de obra especializada.

Por isso, na URSS, o Estado assume de vez o controle do aparato educacional pondo fim às escolas privadas e iniciando o processo de formação dos cidadãos soviéticos através da ação direta de suas instituições. Nessa nova conjuntura política e seus reflexos para a educação, chamamos a atenção para o papel de destaque dado à criança que viria a alcançar status nunca almejado antes em outro país, até aquele momento. Isso ocorre 
porque, na sociedade soviética, além de cidadã, ela passa a ser considerada como participante ativa na construção da ditadura do proletariado.

The primary mission of the Soviet school was to remove children from the "pettybourgeois' family, where the old mentalities of private life undermined the cultivation of social instincts, and to inculcate in them the public values of a Communist society. "The young person should be taught to think in terms of 'we'," wrote Anatoly Lunacharsky, the Commissar for Education, in 1918, "and all private interests should be left behind. (FIGES, O., 2007, p. 19)

O pronunciamento do Comissário de Educação do Povo, Anatoli Lunatchárski, ${ }^{199}$ revela o papel político central agora ocupado pela criança na engrenagem do comunismo. Diante disso, o Partido assume a causa da infância e busca descarnar tal conceito de sua origem burguesa. Por meio de seus aparelhos, o Estado não apenas assume a tarefa de educar as novas gerações, mas emula o patriarcado no cuidado com seus rebentos a partir da substituição da família em sua tradicional configuração. Ao incutir na mente dessas crianças a ideia de que eram privilegiadas por viverem no país soviético, o Partido ganhava cada vez mais defensores ferrenhos de suas instituições e heróis.

Afim de colocar em prática esse modelo educativo, os milhares de crianças e adolescentes moradores de rua à época também são acolhidos através das chamadas Casas da Criança. Além disso, nesse processo, são criadas duas importantes instituições capazes de garantir aos pequenos e jovens soviéticos suas primeiras experiências de participação na vida política, bem como, o devido doutrinamento ideológico. São elas: os Pioneiros (1922) e a Komsomol.

The Bolsheviks saw education as the key to the creation of a new society. Through the schools and the Communist leagues for children and youth (the Pioneers and the Komsomol) they aimed to indoctrinate the next generation in the new collective way of life. (FIGES, O., 2007, p. 19)

Nesse contexto de fortalecimento das instituições responsáveis pela criança e de implementação de reformas educacionais, a literatura voltada para esse público ganha

\footnotetext{
${ }^{199}$ Intelectual bolchevique e um dos fundadores da Proletkult. Foi responsável pelas políticas educacionais revolucionárias, entre elas um programa de erradicação do analfabetismo, chamado LIKBEZ (ЛИКБЕЗ).
} 
especial atenção devido seu potencial formador das gerações vindouras. De modo geral, apenas após a guerra civil (1918 - 1921) que os primeiros esforços são movidos no sentido de estabelecimento da LIJ soviética. Nesse ínterim, aparece um grupo de editoras privadas interessadas em publicar obras para crianças, objetivando garantir sucesso comercial através da inserção desse novo público leitor no mercado ${ }^{200}$. A princípio, começaram a ser publicadas as narrativas tradicionalmente incorporadas à LIJ, como fábulas e contos maravilhosos; bem como obras de escritores russos ${ }^{201}$ e estrangeiros, incluindo biografias de personagens ilustres, consideradas clássicas no gênero. Ou seja, literatura da época pré-revolucionária.

Nos anos subsequentes ao início de tais publicações, entretanto, o Partido efetua mudanças no conteúdo dos livros infantis e exige que eles englobem com mais afinco, através de seus temas, os objetivos educacionais soviéticos ${ }^{202}$. Segundo Balina (2010, p. 91), os trabalhos que abordavam de maneira positiva a infância pré-revolucionária passam a ser tidos como ideologicamente corrompidos e são, portanto, eliminados.

Como vimos, o modo de se abordar a infância, naquele momento, precisava obedecer à etiqueta soviética. Portanto, a literatura não podia mais retratar a vida de crianças que cresciam rodeadas pelos privilégios de famílias nobres. Assim, por exemplo, as reminiscências felizes da infância rica de Liev Tolstói são suplantadas pelas lembranças de dor, perdas e injustiça social que marcaram a de Máximo Górki, escritor

\footnotetext{
200 Nesse momento, ainda havia espaço para iniciativas comerciais não-governamentais devido à instauração da NEP (Nova Política Econômica - Новая экономическая политика) que consistia na abertura temporária para algumas iniciativas de capital particular como meio de incentivo à economia. No conto "De como uma velhinha comprava tinta" (1928), um dos cenários descritos é, justamente, o mercado onde se comercializavam produtos alimentícios.

${ }^{201}$ Entre os escritores russos canônicos do gênero temos: Liev Tólstoi com a trilogia "Infância" (1852), "Детство"; "Adolescência" (1854), "Отрочество"; "Juventude" (1857), "Юность". Sieguei Aksakov com "Os anos de infância de Bragov neto" (1856), em russo "Детские годы Багрова-внука". Е "Тетаs da infância" (1892) - "Детство Tемbl" - de Nikolai Garin-Mikhailovski.

${ }^{202}$ Em 1921, o "Instituto para o estudo das crianças leitoras", sob o suporte da "Comissão do povo para Educação", passa a lançar um boletim mensal com o intuito de informar escritores e editoras sobre a literatura infantil e sobre modos de como revalidar textos pré-revolucionários.
} 
símbolo do proletariado. Este, aliás, foi dos pioneiros na Literatura infantil soviética através da qual pretendia desenvolver nas crianças o espírito de participação ativa.

Sabemos, como bem nos lembra Nelly Novaes Coelho (2000, p. 226), que a literatura infantil desde sua origem possui as intenções de educar e divertir seu leitor, sendo que esses dois propósitos estão, em geral, sempre presentes nos trabalhos direcionados para as crianças.

Já em épocas de consolidação, quando determinado Sistema se impõe, a intencionalidade "pedagógica" domina praticamente sem controvérsias, pois o importante para a criação no momento é transmitir valores para serem incorporados como "verdades" pelas novas gerações. (COELHO, N. N., 2000, p. 43)

Nessa dinâmica, uma série de fatores sócio-políticos e culturais determinam qual dos aspectos será enfatizado - divertir e / ou ensinar. Na URSS, por sua vez, todas as intenções foram concentradas na literatura pedagógica. Escritores militantes buscavam construir modelos literários adequados tanto ao gosto aos pequenos leitores, quanto aos interesses do regime. Respirava-se o clima de coletividade, de modo que, todos, adultos e crianças, em algum momento de suas rotinas eram inseridos num espaço educador e transmissor do modo de vida soviético, seja nas escolas, seja nas fábricas, seja ao fazer compras. Não havia mais espaço para o indivíduo.

As crianças soviéticas eram rigorosamente doutrinadas conforme os valores da ditadura do proletariado, logo cedo, aprendiam a importância conferida à educação, ao trabalho e à vida coletiva, tendo em vista que eram o embrião do futuro homo sovieticus. Verificamos que, num espaço de tempo relativamente curto toda uma máquina educacional passa a estar cada vez mais integrada à vida soviética. Apenas para exemplificar, algumas delas funcionam como cenário dos contos de Kharms: a Casa da Criança, em “O fusível travesso” (p.); a escola foi o ambiente em que Vássia revelou sua 
força em "O quebra-ossos" (p.); o acampamento dos Pioneiros põe à prova as habilidades dos amigos Kólia Kókin e Vânia Mókhin (p.)

It is impossible to understand the evolution of Soviet children's literature outside the context of the evolution of Soviet pedagogy, and in particular outside the connection of Soviet pedagogy with violence and strategies of discipline being developed in the Soviet Union. Soviet children do not just go to school, go on excursions, play war games and sing war songs, sit around the Pioneer campfire, made model airplanes and ships, play with gliders, and join the Young Naturalists, thus becoming part of the collective boy. In reading books about heroes and about everyday life of the school, they also enter into the collective spirit. (DOBRENKO, E., 2010, p.48)

Observamos, porém, que o didatismo existente na literatura infantil também era de ordem diferente daquele empregado nas obras para adultos, tendo em vista que, estes precisavam passar por uma "reeducação" nos moldes soviéticos, enquanto que as crianças estavam em processo primário de educação. Ou seja, antes de terem sido contaminadas pelo sistema burguês, já seriam previamente moldadas pelo regime; sua função, inclusive, era a de ajudar aos pais acompanharem os avanços sociais ${ }^{203}$.

Contudo, conciliar a exigência de emprego dos conteúdos comunistas com a produção de textos criativos capazes de atrair os leitores iniciantes era uma tarefa complexa que exigia habilidade daqueles autores dispostos a contribuir com o gênero. Como lidar com temas ideológicos sem perder os elementos de ludicidade subsistente à LIJ? Diante dessa problemática, artistas e educadores perceberam a imprescindibilidade de investimento na construção de novas histórias. Para tanto, foi necessário recrutar escritores talentosos pela capacidade de veicular de forma artística os tópicos socialmente obrigatórios: internacionalismo, educação pelo trabalho, simplificação da linguagem para fácil compreensão, inclusão da realidade e personagens soviéticas aos textos e orientação

\footnotetext{
${ }^{203}$ LIJ é separada em categorias: pré-escola (5 - 7 anos); jovens alunos ( $7-11$ anos); adolescente $(11-15$ anos) e jovens adultos (15 - 18 anos).
} 
política de esquerda. Podemos, então, considerar a LIJ à época como um gênero em formação, em busca de novos caminhos e da constituição de um corpus.

Em Leningrado, muito contribuiu com essa missão o escritor Samuil Marchák, que à época liderava um projeto de criação de uma biblioteca para a literatura infantil junto ao Narkompros ${ }^{204}$, além de trabalhar intensamente, desde 1922, para o estabelecimento desse gênero na URSS. Abraçando a causa da LIJ soviética, ele funda, então, as primeiras revistas literárias para crianças nos anos $1920^{205}$ que irão revelar nomes como Daniil Kharms e Aleksandr Vvediênski ${ }^{206}$.

Apesar de tais orientações, para que temas mais palpáveis e próximos da realidade soviética fossem incorporados à arte infantil, a fase inicial da LIJ soviética não possuía contornos rígidos e seu despontar, naquela atmosfera de intensas transformações, possibilitou a abordagem de temas variados. Assuntos diversos foram abordados sob o guarda-chuva do gênero, inclusive alguns cabalmente proibidos no Realismo Socialista como as viagens "escapistas" para lugares exóticos. Do mesmo modo, recebem destaque àqueles relacionados à modernização tecnológica.

And children's literature of 1920s and 1930s did indeed tell of history: of the civil war and its heroes (including children heroes), of technology (the subway, stratostats, steamships and icebreakers, trains and factories), of fascinating journeys and remarkable explores and heroic expeditions (to the most exotic places, from the Amazon to the Artic Circle), of animals, and of adventures. There was a blossoming for children of so-called nauko-fantastítcheskaia (science fiction), nauko-populiárnaia (popular science) and nauko-tékhnikaia (scientifictechnical literature), which explained how a car was built or how to make your own model glider, model ship, mechanical toy, homemade telegraph, or musical instrument. (DOBRENKO, 2010, p. 47).

\footnotetext{
${ }^{204}$ Comissariado de Educação do Povo. (Народный комиссариат просвещения).

205 Revista "O Pardal" (em russo Воробей - vorobiei), 1923 - 24; revista "Novui Robinson" (em russo Новый Робинзон), 1924 - 25; revista "O tentilhão" (Чиж - Tchij, abreviatura de "Tcheresvitcháino interesni jornal” - Uma revista muito interessante.), publicada entre 1930 e1941; revista “O ouriço" (Ёж Ioj, abreviatura de "Iejmíciatchni Jornal" - Revista Mensal), publicada entre 1928 e 1935.

${ }^{206}$ Naquele momento a publicação de obras de literatura infantil por escritores que escreviam para público em geral, era bastante difundida. Mandelstam e Pasternak, por exemplo, haviam contribuído com alguns trabalhos para as revistas "O pardal" e "Novo Robinson".
} 
Compreendemos que essa variedade de repertório vai ao encontro das demandas infantis por histórias capazes de extrapolarem os fatos do cotidiano e trazerem à baila o universo da imaginação. Pois, "atentando-se para a natureza dessa literatura, vemos que sua matéria pertence à área do maravilhoso, da fábula, dos mitos ou das lendas, cuja linguagem metafórica se comunica facilmente com o pensamento mágico, natural nos seres intelectualmente imaturos". (COELHO, N. N., 2000, p. 38)

Assim, o fato de terem sido alçadas à posição de "crianças soviéticas", construtoras de uma nova sociedade supostamente mais avançada, como pretendia a utopia do Estado, não era condição suficiente para que perdessem o gosto pelo maravilhoso e pelo extraordinário. Portanto, a relação desse pequeno leitor com o mundo imaginário ainda permitia que escritores de literatura infantil tivessem uma liberdade mínima de criação e usassem a fantasia, deixando em suspenso os rígidos padrões vigentes na literatura para adultos. "Se a criança vê fadas, gnomos, anjos, ou objetos que têm alma, ela não os vê sem realidade ou matéria, nem há engano em seus sentidos." (SOSA, J., 1978, p. 128)

Com base nos estudos de Marietta Tchudakova, Balina (2010, p. 10) ressalta acerca da LIJ soviética: "Creative imaginations and fantasy were natural elements of children's literature, and they offered a possibility of escape from the harsh reality that literature for adults denied its writers."

\subsection{O problema do maravilhoso}

"Cavaleiros andantes, reis, rainhas, princesas e príncipes bons e maus, fadas, bruxas, metamorfoses de criaturas humanas em animais (ou vice-versa), ogres e ogressas canibalescos, maldições, profecias, madrastas, crianças abandonadas, crianças que são entregues a alguém para serem mortas, fantasmas e magos, gênios benfazejos e malfazejos... é a fantástica legião de personagens que a partir do século XVII os escritores cultos vão descobrir na 
tradição oral dos povos europeus e criar a Literatura Infantil que hoje conhecemos como 'tradicional'..."

(Nelly Novaes Coelho, 1991, p. 66)

Como vimos, no tocante à LIJ soviética, escritores comprometidos com o governo aspiravam à criação de novos títulos literários que pudessem ocupar o lugar daqueles consagrados à época pré-revolucionária. Em última instância, todos os esforços foram movidos para a ruptura com o ranço do passado tzarista e burguês e, naquele momento, os elementos ligados ao fantástico-maravilhoso, historicamente presentes no gênero, entravam em choque com a demanda pela fixação temática nos fenômenos da realidade concreta. Assim como ocorria com essa tradição no conjunto da literatura russa.

Nesse sentido, a literatura infantil pregressa à Revolução Russa começa a passar pelo crivo do Partido, afim de provar sua adequação ou não à ideologia comunista. Por isso, muito discutiu-se a respeito da utilização pedagógica do acervo clássico da literatura infantil, tendo em vista que essas narrativas, desde suas origens eram paradigmáticas do gênero infantil.

Nadiejda Krúpskaia ${ }^{207}$, Comissária de Educação do Povo e mulher de Lenin, iniciou a discussão acerca dos perigos em torno dessas histórias consideradas como remanescentes da cultura burguesa. Tal tese, que provocou longo debate nos anos 1920 1930, ganhou inúmeros adeptos entre leigos e estudiosos na URSS, sendo responsável pela condenação de contos tradicionais, julgados inadequados.

\footnotetext{
${ }^{207}$ Em maio do mesmo ano [1917], Nadejda Konstantínovna publica o seu famoso Programa escolar municipal, no qual ela propõe ao governo a tarefa de organizar o maior número possível de instituições gratuitas para crianças em idade pré-escolar. Nesta época, Nadejda também liderou um movimento independente de pedagogos que visava à criação de creches e jardins-de-infância para filhos de operários, em Petrogrado (hoje, Leningrado). Suas obras completas, publicadas pela Academia de Ciências Pedagógicas de Moscou, compreendem 11 volumes, tendo sido o principal, A instrução e a democracia, escrito em 1936. Em 1929 é nomeada vice-comissária para a Instrução Pública, cargo equivalente hoje a vice-ministro da Educação. (In: CAPRILES, R., 1989, p. 26).
} 
Histórias de rainhas, príncipes e princesas, vivendo num mágico reino distante, que há séculos povoavam a imaginação de gerações de ouvintes e leitores, passaram a ser consideradas como símbolos do conservadorismo e de um passado em vias de extinção. Por isso, em 1924, escritores da Proletkult condenam a leitura dos contos maravilhosos sob alegação de que faziam exaltação ao tzarismo e, em virtude disso, a coletânea de Afanássiev foi excluída de livrarias e bibliotecas. A despeito do maravilhoso ser um dos elementos mais importantes na literatura destinada às crianças, no modelo soviético, ele era substituído pela exaltação dos grandes feitos do socialismo. Ou seja, a coletividade era a grande produtora de proezas que, na sociedade burguesa, eram possibilitadas apenas na esfera imaginária através da ação mágica. Segundo Marina Balina (2010, p. 10), o Partido buscava adequar os temas presentes na literatura infantil aos princípios do internacionalismo e da educação pelo trabalho.

O caráter aparentemente revolucionário dessas ideias pró-realismo, que estavam associadas à formação de cidadãos atuantes e conscientes de sua realidade social, na prática, gerou a exclusão de obras pertencentes à tradição literária infantil, sobretudo no que diz respeito àquela do fantástico-maravilhoso, ainda em meados dos anos $1920^{208}$.

\begin{abstract}
Na conferência de 1929, na qual foi discutida a preparação do pré-escolar, tratouse do lugar que ocupam os contos de fadas na educação. Pinkevich diz que a questão foi formulada e resolvida da seguinte maneira, o que poderia dar a pauta para exigências ainda mais objetivas, realistas ou materialistas: "Os contos de fadas serão, de modo geral, necessários? Sim. Mas os contos que surjam da vida contemporânea; os contos de fadas que a própria criança crie... (...) deveríamos dar-lhes um novo conteúdo; na medida do possível, deveríamos imprimir-lhes um caráter realista e relacioná-los intimamente com o mundo contemporâneo. Deveriam conter menor número de prodígios e maravilhas e maior dose de fantasia tomada ao mundo circundante. Será que o mundo da realidade não encerra temas suficientes para cativar e reter a imaginação das crianças?" (SOSA, J., 1978, p. 141 - grifos nossos)
\end{abstract}

\footnotetext{
${ }^{208}$ Curiosamente, no mesmo período, na literatura adulta imperavam obras de ficção científica. Uma das mais ilustrativas foi o romance "Nós" (1922), de Evguêni Zamiátin que, de certa forma, anunciavam a falência do regime recém-nascido.
} 
A fala de Albert Pinkevitch ${ }^{209}$, ao citar a possibilidade da própria criança tornarse a autora dos novos contos de fadas, pelo menos em tese, parece ser uma solução inovadora para um problema inerente à LIJ que é a questão da assimetria ${ }^{210}$. Ou seja, ao fato do adulto escrever e/ ou traduzir para a criança, a partir de inferências sobre o que lhe seria adequado. Assim, algumas iniciativas à época tentaram aproximar a autoria da literatura infantil de seu receptor, permitindo que este participasse mais ativamente da criação de histórias.

Balina (2010, p. 12) relata que, em 1933, Górki escreve uma carta endereçada às crianças soviéticas, solicitando saber delas o que gostariam de ler; as respostas recebidas - mais de 7.000 cartas - foram por ele usadas para a confecção de diretrizes gerais, relacionados ao desenvolvimento de novos gêneros e tópicos dentro da LIJ Soviética.

Evidentemente, que a criança pequena, mesmo alfabetizada e com raríssimas exceções, ainda não desenvolveu habilidades de escritora para compor sozinha obras literárias, necessitando de um escriba com pleno domínio da arte de escrever. No caso, eram os escritores, que ainda procuravam os fundamentos de suas obras nas características e estrutura clássicas dos contos maravilhosos; adaptando-as às novas demandas educativas da sociedade.

Dessa maneira, no contexto da atmosfera de debates sobre uma literatura adequada às crianças havia, em contrapartida, quem reconhecesse e estimulasse um uso "atualizado" da tradição literária russa. Os intelectuais partidários dessa atitude de acomodação aproximavam-se das ideias trotskistas, a respeito dos bens culturais russos, ao concordarem que o surgimento de uma nova literatura não excluía a busca de bases nesse arcabouço. Trotsky afirmara: "Uma nova classe não recomeça a criar toda a cultura

\footnotetext{
${ }^{209}$ Albert Petróvitch Pinkevitch, reitor da Segunda Universidade de Moscou. (Nota nossa)

210 cf. ZILBERMAN, R., 1985, p. 49.
} 
desde o início, mas se apossa do passado, escolhe-o, retoca-o, recompõe-no e continua a construir daí." (Trotsky, 1969, p. 150)

Em se tratando de LIJ não havia como ser diferente, pois conforme esclarece Regina Zilberman (1985, p. 49): "Se o conto de fadas se revelou mais apto à formação de um catálogo de textos destinados às crianças, devido às qualidades mencionadas acima, isto significa que a literatura infantil somente merece esta denominação quando incorpora as características daquele gênero."

Um dos defensores do conto maravilhoso, em sua nova faceta, era o próprio Marchák que, no Primeiro Congresso dos Escritores Soviéticos (1934), apresentou uma comunicação "Sobre a grande literatura para os pequenos", na qual defendeu a criação de contos de fadas soviéticos, capazes de mesclar o folclore com a ideologia comunista através da utilização das qualidades utópicas dos heróis folclóricos adaptadas às virtudes igualmente ideais do homo sovieticus. (Tippner, 2010, p. 311-312)

A polêmica entre defensores e contrários ao uso didático-literário dos clássicos percorreu a cena da LIJ nas primeiras décadas da URSS, mas apesar do embate, várias releituras deles foram realizadas à época. Em 1936, por exemplo, o dramaturgo Evguênii Schwartz (1896 - 1958), reconhecido por suas produções para crianças, compôs uma versão de "Chapeuzinho vermelho" em que a personagem principal não figura mais como uma menina vitimada, mas ela é membro atuante dos Pioneiros e vence o perigo que encontra ao mobilizar um conjunto de animais para juntos lutarem contra o lobo opressor. (Tippner, 2010, p. 309)

O aproveitamento que Schwartz faz do conto dos irmãos Grimm foi possível, sobretudo, devido à versatilidade das obras oriundas da tradição folclórica, principalmente, no diz respeito a incorporação de novos temas ligados às demandas 
sociais que vão sendo criadas. Assim, Chapeuzinho Vermelho passa a abordar o tema da luta coletiva, tão pertinente à sociedade comunista, além de, incluir no enredo personagens ligadas à vida soviética, afastando-se do maravilhoso. Essa peça elucida o modo como artistas se desvencilhavam dos riscos de utilização da literatura prérevolucionária e parodiavam os contos maravilhosos conferindo-lhes uma roupagem soviética.

Os contos kharmisianos "para crianças", tema deste trabalho, estabelecem o diálogo com a literatura infantil dessa tradição. Porém, enquanto na peça de Schwartz, a paródia é adaptada para à realidade privando a atuação sobrenatural, Kharms subverte os elementos convencionais dessas narrativas e procede a uma atualização do fantásticomaravilhoso, possibilitando sua continuidade na LIJ soviética. ${ }^{211}$

\footnotetext{
${ }^{211}$ Como bem apontou Sheila Oliveira Lima em sua análise da novela $A$ velha, a intertextualidade desponta como uma das chaves para a compreensão da literatura de Kharms, cujo intertexto funciona tanto na qualidade de elemento integrador do enredo, quanto característica procedimental do modo de escrita desse artista. Assim, a autora identifica nessa obra o diálogo que Kharms estabelece com alguns de seus autores prediletos, entre eles, Nikolai Gógol, Knut Hamsun, Lewis Carroll e Edward Lear. Cabe observarmos que as relações entre ambas as obras - os textos de Kharms e os referidos - são sugeridas por meio de elementos "pontuais" componentes da narrativa. Por exemplo, uma epígrafe de Hamsun, aparentemente despretensiosa, denuncia o cenário literário à época; um relógio sem ponteiros e uma lagarta aludem à Alice no país das maravilhas e aproximam a Rússia soviética do período de mandos e desmandos da Inglaterra vitoriana; entre outras alusões. Podemos verificar, contudo, que as referências às personagens, aos temas e aos elementos das obras destes escritores apresentam-se integrados de tal forma ao texto da novela que, para serem desvendados, exigem do leitor atenção aos detalhes e às possibilidades de interpretação presentes nas entrelinhas da história.
} 


\section{A literatura infantil de Daniil Kharms: tradição e modernidade.}

\subsection{Tradição e Modernidade}

Nas primeiras décadas do regime soviético, todas as esferas da vida e da sociedade passam por um intenso processo de transformação e modernização, nos moldes soviéticos: as áreas ligadas à educação receberam atenção especial do Partido.

O amplo aparato educacional, do qual faziam parte a literatura e todas as demais formas artísticas, fora pensado como uma engrenagem de onde nenhum cidadão ficaria sem participar: a cultura soviética penetrava mentes e corpos. O coletivismo, o aperfeiçoamento do homem por meio da educação e do trabalho; o ateísmo, o repúdio ao passado tzarista e à propriedade privada, o culto aos símbolos da revolução, entre outros temas, eram assuntos abordados e perpetuados pelos escritores através do tratamento literário dos feitos do super-homem soviético: o homo sovieticus.

Essas transformações pretendiam arrancar os russos de seu passado, marcado pela religiosidade, ignorância e desigualdade social, para lançá-los, de uma vez por todas, numa sociedade moderna e refeita pelas mãos do homem. Nesse contexto, a literatura enquadrava-se num sistema de divulgação ideológica e de doutrinamento político, sendo ela, produto e motor dessa modernidade.

Com esse intuito, antigas tradições socioculturais começam a ser substituídas por novas, de modo que a herança tzarista é gradualmente apagada através de um processo que custou a vida de milhares de soviéticos. O mecanismo de implantação de novas tradições é discutido por Eric Hobsbawn ${ }^{212}$, para quem um conjunto de práticas recémcriadas pode, rapidamente, ganhar ares de antiguidade e transformar-se em tradicional, através da repetição e do vínculo com o passado:

\footnotetext{
${ }^{212} \mathrm{cf}$. A invenção das tradições. op. cit.
} 
Por "tradição inventada" entende-se um conjunto de práticas, normalmente reguladas por regras tácitas ou abertamente aceitas; tais práticas, de natureza ritual ou simbólica, visam inculcar certos valores e normas de comportamento através da repetição, o que implica, automaticamente, uma continuidade em relação ao passado. (HOBSBAWN, E., 2008, p. 9)

No caso soviético, toda a produção industrial e cultural tinha a finalidade de suplantar a velha sociedade de classes e abrir espaço à construção de uma configuração cujo poder estivesse em mãos dos proletários, verdadeiros construtores da época moderna. Contudo, práticas herdadas da época tzarista, como a burocracia e o autoritarismo, por exemplo, têm continuidade no novo regime, sobretudo no período stalinista, e dão mostras da subjacência do passado burguês na moderna URSS.

Provavelmente, não há lugar nem tempo investigados pelos historiadores onde não haja ocorrido a "invenção" de tradições neste sentido. Contudo, espera-se que ela ocorra com mais frequência: quando uma transformação rápida da sociedade debilita ou destrói os padrões sociais para os quais as "velhas" tradições foram feitas, produzindo novos padrões com os quais essas tradições são incompatíveis; quando as velhas tradições, juntamente com seus promotores e divulgadores institucionais, dão mostras de haver perdido grande parte da capacidade de adaptação e da flexibilidade; ou quando são eliminadas de outras formas. (HOBSBAWN, E., 2008, p. 12)

Para efetuar a substituição de uma tradição considerada antiquada por uma nova, o Partido lança mão de muitos dos símbolos da antiga Rússia, dando-lhes uma função atualizada, no contexto da ditadura do proletariado.

Uma das cenas do longa “Путёвка в жизнь" (O caminho da vida), dirigido por Nikolai Ekk, em 1931 e baseado na história do educador Anton Makárenko ${ }^{213}$, ilustra esse processo de implantação da novidade revolucionária, a partir da instauração de uma nova tradição: a câmera mostra ao expectador uma antiga igreja ortodoxa de aldeia para onde é levado um grupo de garotos resgatados das ruas da metrópole. Os meninos entram no local, onde agora funciona uma fábrica comunal de trabalhadores. Numa tomada de cena,

\footnotetext{
${ }^{213}$ Anton Makárenko (1888 - 1939) foi educador e trabalhou com jovens desde 1920. Escreveu "Poema pedagógico" no qual defendia a redenção através do trabalho.
} 
focaliza-se uma porta fechada, no interior da velha nave. Cria-se o clima de expectativa, sob os olhares atentos dos jovens. Eles não ousam tocá-la. O professor que acompanha o grupo toma a dianteira, abrindo-a aos poucos. Para a surpresa de todos, ao invés dos objetos pertencentes ao culto religioso, o público vê que lá dentro há martelos, plainas, chaves fixas e outras ferramentas manuais. Pois por meio do trabalho, esse grupo seria educado para servir à ditadura do proletariado.

Assim, os símbolos da religião, que representavam o ócio, a alienação e a inutilidade, davam lugar aos símbolos do trabalho, tido como um elemento produtivo e libertador dos novos tempos. A pátria soviética, ostentada como baluarte do que havia de mais moderno e avançado na história da humanidade até então, promovia oficialmente a modernização da sociedade. Processo pelo qual também passava a literatura.

Nesse clima de mudança, os cânones literários russos foram reprimidos e substituídos pelo Realismo Socialista. A tônica das novas obras deveria basear-se na vida dos cidadãos soviéticos, nos feitos revolucionários e na realidade do proletariado. No que diz respeito à LIJ, a tradição relacionada aos contos maravilhosos e às fábulas passa a ser substituída por novos trabalhos capazes de lidar com as demandas da criança soviética e, ao mesmo tempo, educá-las com os valores revolucionários de sua pátria.

Os intelectuais envolvidos com a LIJ, à época, eram todos trabalhadores cientes de seu potencial na formação dos pequenos cidadãos. Portanto, empenhavam-se para fazer desse gênero um produto genuinamente soviético. Entretanto, naquele período, tal gênero ainda dava margem a uma pequena liberdade de criação, em comparação aos trabalhos destinados ao cidadão adulto.

Assim, Kharms tem a oportunidade de mesclar elementos tradicionais, como o fantástico-maravilhoso, com informações da realidade social e, também, com 
procedimentos da experimentação moderna. Características que tornam sua obra bastante singular: dotada de marcas estéticas modernas que a tornam atrativa até os dias atuais.

\subsection{Marcas do cotidiano e da modernização social na literatura infantil kharmisiana}

Kharms contempla a preocupação com a atualização da literatura infantil ao trazer para seus contos elementos da realidade soviética, que passam a dividir espaço com o universo da fantasia, típico do gênero. Assim, marcas daquele momento histórico perpassam o enredo dos contos, de modo que espaços, personagens, instituições e marcação temporal demonstram a tentativa do escritor em lidar com a apreensão do real, através de sua obra.

Acerca do espaço, local onde transcorrem as ações dentro da narrativa, Coelho (2000, p. 72) afirma:

Ele determina as circunstâncias locais, espaciais ou concretas que dão realidade e verossimilhança aos sucessos narrados. Sua importância na efabulação é idêntica à que o mundo real adquire em nossa vida cotidiana. Meio familiar, social e econômico; tipo de habitação; clima; nação; objetos que nos rodeiam na intimidade; a moda de nossos trajes; a profissão que exercemos etc.

A criança soviética, que lia os trabalhos de Kharms, reconhecia nos contos do escritor a ambiência da Leningrado stalinista que deixava de prestar atenção nos palácios e igrejas da velha aristocracia para dar ênfase "às chaminés e os telhados que apontavam para o céu" (p. 51), símbolos de um novo tempo.

Os espaços sociais "modificados pela técnica, pelo trabalho modificador do homem" (COELHO, N. N., 2000, p. 73) são marcantes e acompanham a tentativa de aproximação entre literatura e cotidiano concreto. Para criar um clima de atualidade, no interior dos contos, Kharms inclui neles, de forma expressa, topônimos e objetos que, de fato, existiam e faziam parte do repertório de seu público leitor: 
São alguns exemplos disso a referência à rua Mokhováia, em Leningrado, local apontado como residência de Kolka e Piétka quando voltam do Brasil; a alusão ao Jardim de Verão, onde o narrador-personagem de "Uma vez perguntaram-me como funciona o automóvel" foi interceptado por alguns garotos; a menção ao Primus - um rústico fogareiro muito popular, na URSS, entre as décadas de 1920 a 1930, usado no preparo de refeições e também no aquecimento - que chiava, ao longe, enquanto Platon balançavase na rede. Também queremos destacar a presença das repartições públicas, apartamentos coletivos, instituições de ensino, entre outros locais tipicamente soviéticos que aparecem como cenários para os contos: Comitê de Invenções, do Vesenkha; redação da revista Tchij (onde Kharms trabalhava), escolas, Casa da Criança etc.

A familiaridade da criança com cenários e objetos presentes nas narrativas dava à obra um caráter mais palpável. Do mesmo modo, as formas de tratamento tipicamente soviéticas como "camarada" 214 e "cidadão (ã)" ajudam a compor a nova atmosfera. Tendo em vista que a planificação social atingiu até o modo como as pessoas tratavam-se entre si.

No conto "Como uma velhinha comprava tinta", por exemplo, a protagonista vai até uma feira. Este local, naquele momento histórico, retratava os últimos resquícios do capitalismo dentro da URSS, antes da transposição efetiva dos meios de produção industriais e agrícolas para o Estado ${ }^{215}$. As cenas de livre comércio representadas pelas personagens, nesse conto de 1928, em breve seriam extintas da vida soviética devido ao fim da NEP, no mesmo ano:

\footnotetext{
214 Camarada (товарищ) era a forma de tratamento usada inicialmente entre companheiros do Partido e depois estendida à população em geral.

${ }^{215}$ O conto "Sobre como uma velhinha comprava tinta" foi publicado no último ano da NEP (Nova Política Econômica) que consistia num plano econômico implantado na URSS, entre 1922e 1928. Seu intuito era recuperar, de forma assistida, alguns traços do capitalismo através da existência de pequenas propriedades privadas e da livre iniciativa com vista o fortalecimento da economia soviética.
} 
Ele jogou o peixe para cima com as duas mãos, depois pegou com uma das mãos pela fuça sacudiu, sacudiu, soltou, mas sem deixar cair e com agilidade apanhou pelo rabo com sua outra mão e aproximou-o da velhinha.

- Olhe, — diz - por um rubro é seu.

— Não, — diz a velhinha - é de tinta...

Mas o rapaz não a deixou terminar.

— Pegue! — diz — Não estou pedindo muito.

— Não, — diz a velhinha — é de tinta... (p. 62)

Outro objeto, símbolo dos meios de produção revolucionários, a figurar nas histórias de forma significativa é o automóvel que, mesmo não fazendo parte do cotidiano dos cidadãos, pois estes se locomoviam em transportes coletivos, era um dos objetos mais representativos da vida moderna e industrializada. Por isso, essa máquina futurista povoava a imaginação de adultos e crianças. Assim, enquanto os contos maravilhosos possuíam seus cavalos mágicos, tapetes voadores, sapatos alados entre outras formas extraordinárias de locomoção, a literatura infantil kharmisiana substitui a magia pelas conquistas mecânicas da humanidade.

Ao abordar as grandes mudanças arquitetônicas na cidade moderna do século XX, Marshal Berman (2014, p. 199) afirma: “O homem na rua se incorporará ao novo poder tornando-se o homem no carro. A perspectiva do novo homem no carro gerará os paradigmas do planejamento e design urbanos do século XX.”

É o caso de "Em primeiro e em segundo lugar", em que o carro é um auxiliar que possibilita o deslocamento das personagens: "desembarcamos na outra margem e avistamos um automóvel. - 'O que vem a ser isso?' - pergunta o homem comprido. — 'O que é isso?' - pergunta o homenzinho. 'Isso é um automóvel' — respondo. — 'É o carro que usaremos agora' - disse Pietka” (p. 33) (grifos nossos).

Torna-se pauta de interrogatório, no conto "Uma vez perguntaram-me como funciona o automóvel":

Uma vez perguntaram-me como funciona o automóvel. — Não sei — respondi eu. 
— Não, mesmo assim, conte como ele funciona — insistiram.

— Não sei — disse eu - e basta.

E, de fato, eu nem imagino como é que funciona um automóvel. (p. 92) (grifos nossos)

Confundido com um monstro, o automóvel transporta os dois garotos do mundo imaginário à cidade de Leningrado, em "Como Kolka Pánkin voou para o Brasil e Pietka Erchov não acreditou em nada":

Kolka Pánkin e Pietka Erchov olharam para trás. Bem na direção deles vinha voando um monstro.

— O que é isso? - assustou-se Kolka.

— É um automóvel. - disse Pietka.

Brasil?

— Não pode ser! — disse Kolka. — Como um automóvel veio parar no

— Não sei — disse Pietka — só sei que isso é um automóvel.

— Não pode ser! — disse Kolka.

— Mas estou dizendo que é um automóvel! — disse Pietka.

— Não pode ser! — disse Kolka.

— Pode! - disse Pietka.

- Não pode!

— Então, está vendo, agora, que é um automóvel? — disse Pietka.

— Estou vendo, mas é muito estranho. - disse Kolka.

Nesse ínterim o automóvel chegou mais perto. (p. 49) (grifos nossos)

O tumulto da cidade grande com seus prédios e diversos meios de transporte (carros, bondes, motocicletas) aparece enquanto símbolo da modernização promovida pelo governo:

A velhinha apanhou o guarda-chuva, segurou-o com mais força e bem depressa, mais que depressa, seguiu caminho, calçadas afora, virando de uma rua na outra, indo sair numa terceira, larga e muito barulhenta. Ao redor o povo corre para todos os lados, na via correm os carros e o bonde zune.

Foi só a velhinha querer atravessar para o outro lado, de repente:

— Fon, fon, fon! - grita o carro.

A velhinha deixou-o passar e, foi só pôr o pé na rua, gritaram:

— Ei, cuidado! - grita um cocheiro. (p. 65).

"Nessa rua, como na fábrica moderna, o modelo mais bem equipado é o altamente automatizado: nada de pessoas, exceto as que operam as máquinas; nada de pedestres desprotegidos e desmotorizados para retardar o fluxo" (BERMAN, M., 2014, p. 199). Ao ignorar as regras dessa nova organização, a velhinha mostra-se inábil para transitar na 
cidade, tornando-se vítima e alvo de ridicularização. Cenas que se repetem com a "porta de vidro giratória" e o "elevador", também objetos dessa modernidade:

A velhinha empurrou a porta e eis que, por trás, algo a empurrou.

Virou-se para olhar e outra porta de vidro vinha em sua direção. A velhinha foi para frente e a porta atrás dela. Tudo ao redor era de vidro e tudo girava. A cabeça da velhinha pôs-se a girar, ela mesma não sabia para onde estava indo. (p. 66) (grifos nossos)

A velhinha abriu a portinhola devagarinho, entrou por ela e viu um recinto bem minúsculo feito um armário. E no recinto havia um homem. Mal ia a velhinha perguntar-lhe sobre tinta...

De repente: "Dim! Dimmm." - e o chão começou a subir.

A velhinha não tinha coragem de se mexer e era como se uma pedra apertasse seu peito. Lá ficou ela sem conseguir respirar. (p. 67)

Naquele período, a política cultural exigia que os elementos narrativos pudessem suportar os valores soviéticos. Dessa maneira, as personagens eram as principais portavozes do modo de vida revolucionário da URSS e, portanto, deveriam apresentar características de coletivismo, disciplina, amor ao trabalho, patriotismo e ateísmo. Em contrapartida estavam aquelas que agiam por si, tinham pensamento independente e não eram maleáveis. (O’DELL, F. apud RUDOVA, L., 2008, p. 32)

Tradicionalmente, na literatura infantil, as personagens mais recorrentes eram as personagens-tipo ou "planas", que não mudam seu padrão de ação e desempenham ora papeis sociais determinados (engraxate, pescador, soldado etc), ora funções dentro de uma esfera do enredo (príncipe, bruxa, anão etc). Entre estas últimas, Propp (1984, p. 44) distinguiu sete categorias presentes nos contos maravilhosos: antagonista, doador, auxiliar, princesa, mandante, herói e falso herói. Nestes casos,

(...) a vontade dos personagens, suas intenções, não podem ser consideradas marca essencial para sua definição. O importante não é o que eles querem fazer nem tampouco os sentimentos que os animam, mas suas ações em si, sua definição e avaliação do ponto de vista de seu significado para o herói e o desenvolvimento da ação. (PROPP, V., 1984, p. 45) 
Esses estereótipos são facilmente compreendidos pela criança, sobretudo, por não darem margem à ambiguidade, podendo ser rotulados por suas qualidades: bons ou maus, nobres ou ordinários, espertos ou tolos etc. Tornam-se eficientes, quando transportados para a LIJ porque, em geral, contribuem para que os escritores trabalhem valores e questões de exemplaridade, elementos marcantes nas narrativas populares e infantis. Acerca disso, devemos lembrar da posição de destaque que os animais antropomorfizados alcançam na transmissão de preceitos moralizantes, no âmbito das fábulas.

Kharms traz para seus contos muitas personagens-tipo que, em geral, estão ligadas ao campo das profissões. Ou seja, tendem a deixar o âmbito do maravilhoso e passam a representar seu contexto social, numa demonstração de valorização do universo do trabalho. Assim, há vendedores, datilógrafos, ascensoristas, professores, funcionários públicos, escritores. Todos eles ganham um lugar dentro do enredo e participam da construção da pátria socialista.

Alguns são representados nos lugares onde exercem suas funções:

No terceiro dia, desde bem cedo, o eletricista andava por toda a Casa da Criança com uma longa escada dobrável dupla. Em cada cômodo ele abria a escada, subia nela, passava a mão em círculo pelo teto, pelas paredes, acendia e apagava diferentes lâmpadas; depois, por algum motivo, corria para o vestíbulo onde, sobre um cabide, ficava o medidor de energia e uma plaquinha de mármore com fusíveis. (p. 26) (grifos nossos)

Vejam vocês mesmos, fui trabalhar de vigia numa exposição de gatos. Deramme luvas de couro para que os gatos não me arranhassem os dedos, me mandaram colocar cada gato em uma gaiola e escrever na gaiola o nome de cada um. (p. 129) (grifos nossos)

A velhinha mais de perto:

- Tinta! - grita.

— Saia da frente! - grita o zelador jogando água.

A velhinha foi para a esquerda e o jorro para a esquerda. (p. 67) (grifos nossos)

O zelador, em especial, era uma figura bastante representativa do cotidiano soviético. Todos os apartamentos comunais e conjuntos residenciais possuíam essa figura, responsável tanto pelas funções típicas dessa profissão, quanto pela sondagem da vida de 
seus habitantes. Eram eles os responsáveis por reportar às autoridades atos de subversão ou "atitudes suspeitas".

As personagens da "vida real" eram chamadas, à época, para relatar suas experiências de trabalho para a construção da pátria socialista. De modo que, a inclusão dessas personagens proletárias mostra que Kharms estava atento à exigência políticopartidária de tratamento literário às experiências dos cidadãos soviéticos. Por isso, alguns contos estão em primeira pessoa e trazem relatos cotidianos ou lembranças de vida de tipos sociais comuns: funcionário de uma exposição de animais (Os sete gatos), colega de escola (O quebra-ossos), criança em idade escolar (No ano passado fui comemorar o ano novo), garoto soviético (Certa vez comprei um lápis) etc. Verificamos a tentativa de imitação das características do narrador tradicional que "retira da experiência o que ele conta: sua própria experiência ou a relatada pelos outros" (BENJAMIN, W., 1995, p. 201)

Muitos escritores visitavam fábricas e construções afim de coletarem histórias verídicas que pudessem ser contadas literariamente. Kharms parodia essa forma de pesquisa. Em "Um atrás do outro", por exemplo, o escritor-narrador retira tema para seu conto de uma visita ao Comitê de Invenções:

Eu cheguei ao Comitê de Invenções, do Vesenkha. Levaram-me até o funcionário da seção de patentes.

- O que deseja? - perguntou o funcionário.

- Eu queria saber, o que é preciso para um inventor fazer invenções importantes e úteis - disse eu. (p. 85)

Entretanto, a vida soviética que se revela é repleta de frustrações e desprovida daquele encanto típico dessa forma narrativa que, tradicionalmente, cativa seus leitores pelo caráter edificante e clássico final feliz. Nesse sentido, a obra kharmisiana mostra seu viés realista.

Em “O quebra-ossos”, por exemplo, o narrador foge da forma narrativa tradicional em terceira pessoa para contar a experiência de Vássia, um antigo colega de escola. Esses 
relatos pessoais, contados como se fossem depoimentos, formavam a história soviética. No conto, Vássia era um garoto dotado de extrema força, mas "não levava jeito" para os estudos, por isso foi com sua família ao Japão, tentar o sucesso como lutador de jiu-jitsu. Entretanto, a experiência do jovem acaba em fracasso. Logo na primeira aula, ele apanha do professor japonês e desiste da empreitada. Quando retorna à URSS, começa a trabalhar como puxador de ônibus quebrados. O teor da história é, então, transmitido pelo amigo escritor à revelia do fortão, como podemos perceber: "Ele contou a história do professor japonês de jiu-jitsu só para mim, por eu ser colega de escola, mas em geral ele não gostava de falar sobre isso para ninguém" (p. 121).

Fracassada também é a experiência de trabalho do vigia, em "Os sete gatos". Ao encontrar emprego numa exposição de gatos, o narrador-personagem desespera-se por não distinguir os animais da exposição: "Não sei o que fazer. Estou totalmente confuso. Não consigo entender nada" (p. 129). A violência presente nas ações cotidianas, decorrente, muitas vezes, do cumprimento das novas regras impostas pelo regime, marca toda a obra e Kharms e pode ser observada no modo como o narrador trata os animais: “Ai! — gritei — gato nojento! Você nem parece gato" (p. 129). A atitude da personagem não cabe no conto infantil, onde o animal tem vida própria

A experiência do garoto Bória, em "Certa vez, comprei um lápis, fui para casa e sentei para desenhar", também não encontra um desfecho feliz. Sua tentativa de realizar um desenho é barrada devido à presença de um inseto em sua casa: "Foi só querer desenhar uma casinha que, de repente, tia Sacha me chamou. Eu deixei o lápis e fui até a tia Sacha" (p. 77).

As instituições educativas faziam parte da rotina dos pequenos soviéticos que, além de frequentarem a escola, podiam ingressar nos Pioneiros. Nesse sentido, a infância soviética era vivida dentro das instituições que visavam a preparação para a vida coletiva 
do futuro cidadão. Dentro das escolas, os Pioneiros representavam os verdadeiros heróis infantis, responsáveis pela realização de trabalhos em prol da vida comum, eles aprendiam desde cedo os valores do mundo soviético. Entre os Pioneiros surgiriam os futuros membros do Partido, de modo que, era uma hora para a criança participar desse movimento.

Uma das práticas comuns desse movimento era a realização de acampamentos onde todos os membros faziam atividades, realizavam trabalhos e praticavam esportes, de modo a vivenciar suas primeiras experiências coletivas, enquanto exemplos para os demais.

As experiências das crianças, nas escolas e com os Pioneiros, aparecem nos contos de Kharms:

Numa história, de 1935, o narrador-personagem, que simula uma voz infantil, fala das festas de ano novo comemoradas em casa de amigos e amigas. Para enfatizar literariamente a diversão encontrada pelas crianças, o escritor aproveita-se do caráter lúdico inerente à literatura infantil e constrói rimas entre o nome do dono da festa com a brincadeira realizada pelas crianças ${ }^{216}$. Por fim, o narrador conclui: "E neste ano, irei à festa de ano novo da escola, lá vai ser mais divertido ainda" (p. 126) (grifos nossos). A ausência de rima, no texto original, entre a palavra "escola" e a atividade que lá será realizada, dá indícios de dúvida sobre o caráter realmente lúdico do ambiente escolar mas, ao mesmo tempo, mostra-o como direito e dever da criança soviética.

Os festejos outrora ligados à religião, como o natal, por exemplo, são substituídos por uma nova festa cívica que deixa de ser celebrada em família, para ser comemorada coletivamente, na escola. A comemoração soviética do ano novo retoma o pinheiro, um dos símbolos tradicionais e presentes no inconsciente coletivo da população, como um

\footnotetext{
${ }^{216} \mathrm{Na}$ tradução não recuperamos a rima, pois optamos manter fidelidade ao texto original.
} 
"novo" marco da passagem do ano: "Todas as crianças dançavam ao redor da árvore de ano novo, mas Volódia sentado no cadeirão chocalha o chocalho" (p. 82)

Num conto anterior, de 1930, o cenário escolhido é o acampamento Pioneiro: “Os dois amigos, Kólia Kókin e Vânia Mókhin estão acampados com os Pioneiros” (p. 81) (grifos nossos). Nesse caso, a demarcação de diferenças físicas entre o "forte, grande e bem disposto" Kólia e o "fraco e magricela" Vânia, que vem a ficar forte por meio de uma "fantástica invenção científica", é usada para transmitir aos leitores a importância da prática esportiva: "agora que Vânia sabe como se sente uma pessoa forte começa a praticar desporto" (p. 81).

A referência aos espaços educativos insiste na mensagem de valorização da educação, do trabalho e do bem comum, tão reiterada naquela sociedade. Em "Um atrás do outro", de 1930, manifesta-se claramente a ideia de que a dedicação aos estudos é, de fato, a única forma do cidadão colaborar de modo útil com a sociedade:

— Mas, então, do que um inventor precisa - disse eu - para criar invenções úteis e necessárias?

— Em primeiro lugar — disse o funcionário da seção de patentes — um inventor precisa estudar muito. Vemos, com frequência, que inventores querem resolver problemas grandes, sem o devido preparo científico para isso. Em segundo continuou o funcionário - o inventor precisa saber de tudo que já foi feito em sua área previamente, senão ele pode estar bem uns cinquenta anos atrasado em sua invenção. (p. 86) (grifos nossos)

Um espaço ligado à educação e formação do futuro homo sovieticus, à época, era a chamada Casa da Criança, uma espécie de reformatório estatal que abrigava desde crianças de rua, órfãs das guerras aos filhos dos, assim chamados, "inimigos do povo" ou “inimigos da ditadura do proletariado". Tal instituição aparece como cenário do conto "O fusível traquinas", cuja fábula parodia uma história de detetive por girar em torno de um mistério: os internos da Casa da Criança 124 estão sendo impedidos de realizar suas atividades, pois a eletricidade acaba todos os dias, deixando-os no escuro. A escuridão, 
além de causar transtorno às atividades pedagógicas, permite que as crianças cometam travessuras: repente.

Quando Seriójka Altofalante aproximou-se do caldeirão, escureceu de

- Acabou a luz! - puseram-se a gritar em diferentes vozes. o Altofalante.

— Ai, ai, ai, veja lá o que está fazendo! — gritava mais alto do que todos (...)

— Altofalante está nadando na sopa. — gritava Kuzmá Parovózov.

No dia seguinte, à noite, quando Paukárlytch mostrava às crianças o novo exercício de ginástica, escureceu de repente.

Fedul Karapúzov, Nina Verióvkina e Nikolai Pniov, repetindo os movimentos de Paukárlytch, escorregaram no escuro e caíram no chão.

-Piotr Sapogov aproveitou-se da escuridão e deu um soco nas costas de Altofalante. (p. 25) (grifos nossos)

Mas aí a luz acabou apagou e fez-se a escuridão.

- Acabou! — gritou Kuzmá Parovózov.

- Apagou! - gritou Nina Verióvkina.

— Já, já acende! - gritou Altofalante procurando no escuro por Pietka Sapogov para, fingindo ser sem querer, dar-lhe um tapa na nuca. Mas Pietka não estava ali. Em um minuto e meio, mais ou menos, a luz voltou de novo. Altofalante olhou ao redor. Nem sombra de Pietka. (p. 27) (grifos nossos)

Vítima das gozações e tapas dos pequenos camaradas, Seriojka Altofalante dispõe-se a solucionar o problema e encontrar o causador dos apagões. Por isso, passa a vigiar os passos dos colegas, vindo a encontrar um culpado em Piotr Sapogov, que aprendera com o eletricista a desligar a luz da Casa. O garoto investigador usa sua descoberta para, por um lado, ameaçar o infrator e, por outro, bajular o professor Paukárlytch.

Por trás do enredo, as entrelinhas do conto revelam o caráter de violência que permeava as práticas sociais nesse microcosmo, onde aprendia-se a ser um cidadão soviético.

Logo após a Revolução e ao longo da década de 1920, as autoridades soviéticas precisaram lidar com o problema da orfandade. A primeira grande guerra e a guerra civil (1918 - 1921), em conjunto com as drásticas mudanças sociais realizadas no período, 
deixaram como consequência uma grande quantidade de crianças e adolescentes em situação de marginalidade, vivendo nas ruas como pedintes ou cometendo delitos. Muitos deles eram órfãos, mas havia quem tivesse sido abandonado pela família ou, simplesmente, fugido de casa.

Families disintegrated, as younger peasants left their homes for the cities. Millions of children were abandoned in these years. (...) Mothers left their children on doorsteps, delivered them to Soviet offices or abandoned them in the nearest town. Orphans lived on building sites. They roamed around the streets, rummaging through rubbish for unwanted food. (FIGES, O., 2007, p. 98)

Uma das soluções encontradas pelo Partido para sanar o problema foi o aumento do número das Casas da Criança, para onde eram conduzidas aquelas que estivessem em situação de desamparo. Esses locais passaram a receber, em número cada vez maior, filhos cujos pais eram considerados inimigos do regime. Esses últimos eram separados de suas famílias e, após a condenação de seus pais, tinham suas identidades adulteradas. "They were told to forget their parents and, if young enough, were given different names to forge a new identity." (FIGES, O., 2007, p. 335) Muitos deles carregavam o estigma de "filhos de inimigos" para o resto de suas vidas e buscavam, a todo custo, escamotear o próprio passado.

Esse dado verídico vem à tona ao observarmos que as crianças kharmisianas, em especial as personagens moradoras da Casa, não têm a referência do nome de seus pais nem no patronímico, nem no sobrenome. Na cultura russa, o patronímico empregado cotidianamente no trato social. Então, quando nos referimos a Karl Ivánovitch, sabemos que este é filho de Ivan; Konstantin Konstantínovitch é filho de Konstantin; Fiódor Fiódorovitch é filho de Fiódor, assim sucessivamente.

Mas uma vez que o regime assumia integralmente a responsabilidade por esses jovens, em muitos casos, com pretensões de substituir o papel paterno, a alusão ao pai biológico não mais importava, pois todos eram filhos do Estado. Assim, os sobrenomes 
encontrados no conto, como Parovózov, Arbúzov, Rubáquin, Múkhin, Verióvkina, entre outros, não fazem parte do repertório russo; são apenas derivados de substantivos como locomotiva, melancia, espadachim, mosca e barbante que, quando transformados em nomes de família, conferem efeito cômico à narrativa.

Curiosamente, o professor Pável Kárlovitch, filho de Karl, é chamado pelas crianças pela alcunha de Paukárlytch. O apelido formado pela contração entre nome e patronímico do mestre alude, igualmente, à palavra russa "palka” (палка), que significa pau, bastão, porrete. No contexto do conto, pode ainda referir-se à rigidez com que o Camarada professor conduzia as atividades junto aos internos, tendo em vista que são as próprias crianças a lhe chamarem assim. Obras artísticas da época, como o já citado filme “Путёвка в жизнь” (O caminho da vida), demonstram bem a violência que permeava os processos educativos de crianças e jovens nessas instituições ${ }^{217}$.

Nelas, as crianças eram educadas conforme o modelo soviético, tomando parte, inclusive, nas novas metodologias pedagógicas em curso à época: construção de maquetes, atividades físicas, jornal-mural. Elas também eram inseridas de forma prática no universo do trabalho, por isso tomavam parte nos afazeres do lugar. Situação visualizada no conto: "Hoje na cozinha estão de plantão Arbúzov e Rubákin, assim como, o professor Pável Kárlovitch ou Paukárlytch.” (p. 24)

The whole purpose of the Soviet school, with its wall newspapers, Lenin Corners, councils and committees, was to instil in children the idea that they too were potential revolutionaries and should be ready to rise up in revolt - if necessary, against their own parents - if called upon to do so by the Party leadership. (FIGES, O. 2007, p. 24)

Para a sociedade soviética era importante que a educação das crianças deixasse a esfera doméstica, como ocorria na sociedade burguesa, e fosse realizada por órgãos

\footnotetext{
217 "I permitted myself to advance my firmly held belief that as long as the collective and the organs of the collective had not yet been created, as long as there were no traditions and the first skills of work and life had not yet been instilled, the teacher has the right and the obligation not to refrain from coercion." (MAKÁRENKO apud DOBRENKO, 2010, p. 45)
} 
públicos comprometidos com valores coletivos. "Orphan children were especially susceptible to the propaganda of the Soviet regime because they had no parents to guide them or give them any alternative system of values." (FIGES, O., 2007, p. 341)

Para tanto, a atuação da família é gradualmente substituída pela do Estado, em todos os âmbitos. Os vínculos entre pais, filhos e irmãos foram enfraquecidos para que os mais jovens não se ressentissem em denunciar às autoridades atitudes antirrevolucionárias manifestas pelos mais velhos. Segundo Figes (2007, p. 8),

Bolshevik theorist agreed on the need to replace this 'egotistic love' with the 'rational love' of a broader 'social family'. The ABC of Comunism (1919) envisaged a future society in which parents would no longer use the word 'my' to refer to their children, but would care for all the children in their community.

Assim, uma das facetas percebida através das personagens de Kharms, nesse conto, é a cooptação da ação infantil pelo Estado através do modo como as crianças soviéticas aprendiam, de fato, a direcionar sua fidelidade ao Partido e ao Camarada Stálin. "The moral system of the orphanage - with its Strong collective and weak familial links - made it one of the main recruiting grounds for the NKVD and the Red Army" (FIGES, O., p. 2007, p. 314)

A prática da delação entre cidadãos era um hábito incentivado pelo Partido, sobretudo nos anos do terror stalinista. De modo que, as pessoas desenvolveram a estratégia de falar aos sussurros sobre assuntos proibidos, afim de não serem ouvidas e denunciadas como inimigas do povo. Isso, porque os cidadãos pressentiam que um informante da polícia podia estar em qualquer lugar. Esse dado social foi abordado por Orlando Figes (2007, posição 264):

In a society where it was thought that people were arrested for loose tongues, families survived by keeping to themselves. They learned to live double lives, concealing from the eyes and ears of dangerous neighbors, and sometimes even from their own children, information and opinions, religious beliefs, family values and traditions, and modes of private existence that clashed with Soviet public norms. They learned to whisper. 
Ao pensarmos em tais questões, parece uma contradição o fato de um garoto ser apelidado de Altofalante, numa "sociedade sussurrante" ${ }^{218}$, como era a soviética. Sua atitude, aparentemente despreocupada em relação ao próprio tom de voz: "porque ele sempre falava a plenos pulmões e não conseguia conversar em voz baixa" (p. 25), mostra que o jovem órfão parece ecoar a fala imperativa das autoridades de seu país, que era também transmitida por altofalantes presentes nas praças públicas e bradavam os deveres dos cidadãos.

No contexto soviético dos anos 1920 a 1930, a democratização do acesso à eletricidade era um dos símbolos da modernização do país. Desse modo, ao desligar a luz e impedir os colegas de realizarem suas atividades educacionais, Piotr Sapogov comete mais do que apenas uma travessura infantil. Naquele momento, sua ação assumia proporções maiores, que podiam ser consideradas como uma sabotagem aos avanços da ditadura do proletariado. Crime para o qual não havia perdão.

O clima policialesco, de investigação das ações uns dos outros, pairava dentro de escolas e demais instituições de ensino: "There were schools where the children were encouraged to organize their own police; where they were invited to write denunciations against pupils who had broken the school rules; and where they even held classroom trials" (FIGES, O., 2007, p. 22). Assim, a postura intimidativa de Altofalante, após a investigação, aproxima-o dos delatores soviéticos, que estavam sempre à espreita de capturar uma atitude suspeita, às vezes, visando perceber uma vantagem. Visto que, ele agride o colega de orfanato e ameaça levar o caso a público:

- Mas que bobo! - disse Altofalante. - Olha aqui, se desligar a força mais uma vez vou contar a todos. Nós organizaremos um Tribunal de camaradas e você vai ver só. E, por enquanto, para não se esquecer, toma! - e bateu em Pietka Sapogov do lado direito das costas.

Piotr Sapogov deu dois passos e levou um tombo, Altofalante recolheu o papel e as réguas, levou-os à sala de desenho e, como se nada disso tivesse acontecido, foi lá para cima. (p. 29) (grifos nossos)

\footnotetext{
${ }^{218}$ cf. FIGES, O., 2007, p. 255.
} 
Depois convence o professor de que fora responsável pelo conserto da eletricidade:

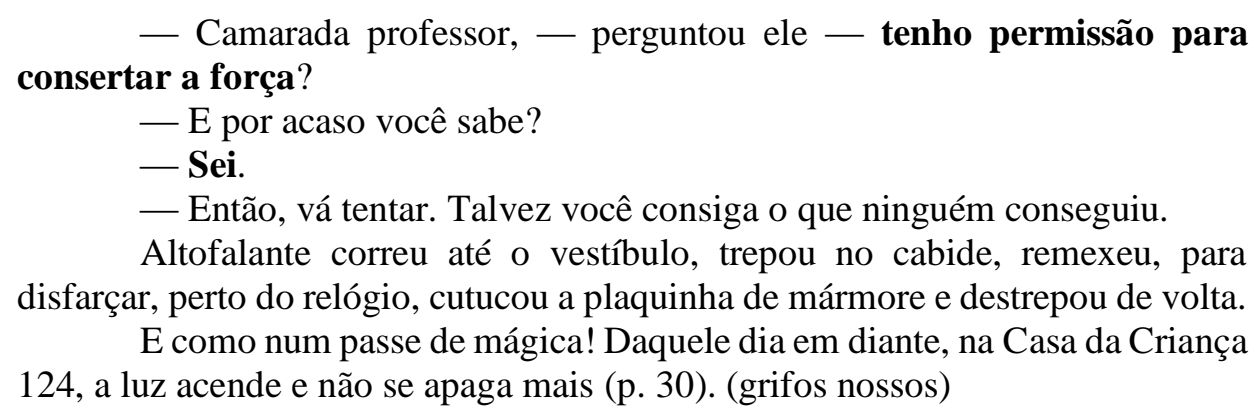

A história que ocorre na Casa parece revelar todo o poder de alcance da educação soviética, além de transparecer o modo de agir autoritário de suas instituições, por meio de seus agentes.

O tempo narrativo é um fator importante, tanto por estruturar a ordem dos fatos, quanto por dizer a respeito da época de ambientação do enredo. A marcação temporal, nos contos de Kharms, é outro fator que demonstra o caráter moderno de sua obra infantil. Nesse sentido, alguns objetos presentes nas narrativas, por si só, também constituem marcadores temporais condizentes com a realidade.

De acordo com Coelho (2000, p. 75),

Há inúmeros recursos de que o autor lança mão para marcar o tempo em sua narrativa, ou para registrar o processo temporal em que as personagens estão envolvidas. A passagem das horas, dias, anos etc. é marcada pela sucessão dos dias e noites; pela sucessão cíclica das estações; pelas modificações do espaço, onde as coisas vão envelhecendo; pelos mil pequenos fatos do cotidiano; pelas datas registradas com precisão etc.

Na LIJ, são mais fáceis de serem apreendidas pelo leitor as marcas naturais dessa passagem (transcorrer dos dias, anos, estações do ano etc) e as cronológicas (horas no relógio, período histórico). Ao passo que, o tempo interior, correspondente às vivências 
das personagens, é melhor percebido pelo leitor iniciante por meio do registro de emoções por elas vividas.

Nos contos de Kharms, encontramos o registro da passagem das horas e dos dias; referência às estações do ano; demarcação do ano ou data específicos, bem como, ordenação matemática. Quase todas essas formas citadas indicam a pretensa ligação com personagens "reais" que organizam suas vidas tendo o relógio e o calendário como parâmetros, ou seja, obedecem uma sequência lógica.

O relógio ${ }^{219}$ é um dos principais símbolos da tentativa humana de dominar o tempo e empregá-lo a seu favor. Naquela conjuntura social, era um objeto importante, pois relacionava-se ao apelo ideológico para que os proletários empregassem sua força de trabalho de modo racional e útil na construção de uma sociedade mais avançada.

O apego ao tempo cronológico é observado no modo de organização das rotinas nas instituições. Por isso, as crianças são chamadas para o jantar "às oito horas em ponto", na Casa da Criança 124. Nessa mesma história, a insistência no tempo associa-se à manutenção do mistério, visto que sua passagem, sem a consequente resolução do problema da eletricidade, intensifica a expectativa de um novo apagão: "O relógio marcou duas horas, depois três, depois quatro, depois cinco, depois seis, depois sete, depois oito. (...) Em um minuto e meio, mais ou menos, a luz voltou de novo. (...) À noite, perto das oito horas, a luz acabou de novo" (p. 27).

Em "Sobre como uma velhinha comprava tinta”, o relógio impõe à velhinha, que vivia no mundo da lua, o tempo real e citadino: “A velhinha olha e à frente há um relógio grande e uma escada que sobe" (p. 67).

\footnotetext{
${ }^{219}$ Presente também na novela "A velha", o relógio sem ponteiros abre possibilidades para interpretação da vida soviética. Segundo Lima (2002, p. 84): "Tudo assumia um novo ritmo, talvez não sem marcadores, mas, certamente, com noções sociais bem diversas daquelas anteriormente consideradas como padrão."
} 
A investida governamental na modernização das estruturas sociais fazia com que projetos gigantescos fossem implantados em períodos curtos. A velocidade das transformações embasava-se na ideia de que o país não tinha mais tempo a perder. A Rússia imóvel do antigo regime ficara definitivamente para trás, fora substituída por uma sociedade dinâmica: a URSS.

Sobre a necessidade de utilização adequada do tempo há uma fala do herói, Professor Trúbotchkin, ao vilão Gigante Bobov, num episódio de "O Professor Trúbotchkin":

- Porque você é um preguiçoso. É por isso que você não sabe nada. - disse o Professor Trúbotchkin - Já eu sei muito porque passo o tempo inteiro estudando alguma coisa. Mesmo nesse momento, estou deitado amarrado, conversando com você, mas em minha cabeça estou revisando a tabuada (p. 107).

A fala da personagem também deixa transparecer que a repetição parece ser um dos métodos de aprendizagem mais eficazes, para aquisição de novos conhecimentos. À época, as teorias de Ivan Pavlov sobre o condicionamento do comportamento e que preconizavam o uso da repetição consistente para remover respostas fisiológicas e psicológicas de seres humanos e animais, sustentavam tais práticas de estudo.

O cuidado com o bom aproveitamento do tempo é observado metaforicamente, em "Olha, Liénotchka (...)" quando a tia sai para fazer compras e deixa à sobrinha a seguinte recomendação: "não coloque semolina no relógio da sala de jantar" (p. 79) (grifos nossos) Uma traquinagem dessa natureza, nesse ambiente de otimização das horas, ganharia efeito simbólico de desestabilização da organização lógica imposta ao cotidiano. Daí a necessidade de cuidado com o relógio, pois, se ele parasse, a narrativa perderia seus parâmetros reais, ingressando no âmbito da atemporalidade, própria do mundo maravilhoso.

As revistas, os jornais e o rádio eram veículos de comunicação que estavam na ordem do dia, dentro do universo soviético, tendo em vista que a imprensa partidária tinha 
o poder de encaminhar ao ostracismo artistas "subversivos" e censurar materiais considerados ideologicamente inadequados.

Nesse sentido, a alusão aos meios de comunicação impressos conferia ares de realidade e contemporaneidade ao enredo dos contos infantis, por isso esses suportes passam a ser componentes da efabulação. A leitura das revistas para crianças é constantemente estimulada e celebrada em diversas histórias: "Compre a Revista Tchij, n. 7 e lá você vai ler uma estória sobre si mesmo" (p. 125); “O quadro era tão bem feito que nós decidimos publicá-lo na Revista Tchij, número 1, de 1936” (p. 128). Além dos livros, a criança soviética, à época, tinha a opção de desfrutar de boas leituras e muita diversão em publicações pensadas para ela.

Em contrapartida, os jornais destinados ao público adulto e veiculadores de notícias supostamente sérias, parecem não receber a mesma atenção, visto que despertam desinteresse na criança enquanto leitora. Em “Certa vez, Pétia Pregov”, o garoto recolhe do chão um pedaço de papel e o narrador afirma: “O papelzinho era um pedaço de jornal. Não era interessante" (p. 135) (grifos nossos). Desse modo, no âmbito da literatura infantil, recebem funções menos nobres do que a leitura. Em "Certa vez, comprei um lápis", a utilidade da imprensa é eliminar um inseto indesejado: "Pegue a barata com

jornal e leve-a para debaixo da torneira no banheiro" (p. 77) Haveria, aqui, alguma relação entre a eliminação da barata e a eliminação de inimigos indesejáveis socialmente? Seja na esfera doméstica, quanto na coletiva o jornal parece cumprir sua função.

\subsection{Aproximação entre obra e leitor}

A interatividade é uma dos contos que pode ser observada por meio da busca de diálogo e inserção do próprio leitor nos caminhos da história. Assim, Kharms usa tanto 
recursos textuais, quanto recursos que extrapolam o suporte da revista onde o conto está impresso.

Para aproximar o conteúdo da leitura da criança leitora são aproveitados procedimentos típicos do próprio gênero, como a oralidade. Segundo Nádia Battella Gotlib (2003, p. 13), os recursos criativos empregados no conto oral podem ser transmitidos ao escrito:

A voz do contador, seja oral ou seja escrita, sempre pode interferir no seu discurso. Há todo um repertório no modo de contar e nos detalhes do modo como se conta - entonação de voz, gestos, olhares, ou mesmo algumas palavras e sugestões -, que é passível de ser elaborado pelo contador, neste trabalho de conquistar e manter a atenção do seu auditório.

Além do uso de fórmulas-prontas, típicas da literatura infantil (era uma vez, certa vez, acabou-se a história), o narrador kharmisiano interage com seu leitor a partir da proposição de perguntas diretas: "Quem aí sabe qual é o grito do ouriço?” (p. 114); “Quem sabe você possa me dizer para onde se escafedeu meu querido Karl Ivánovitch?” (p. 134). Sugestão de charadas 220: “Olhe para esse desenho e diga: qual gato é Machka, qual é Pronka, qual é Bubêntchik, qual é Tchurka, qual é Murka e qual Chtukatiurka?” (p. 130). Apelo propagandístico para aquisição da revista: “Apenas aqueles que assinarem a Revista Tchij no ano de 1934” (p. 110); "O quadro era tão bem feito que nós decidimos publicá-lo na Revista Tchij, número 1, de 1936” (p. 128). Presença de interjeições: “Prestem atenção como era a velhinha!” (p. 61); “Olha só essa história!” (p. 129) “Não dá para acreditar numa coisa dessa!” (p. 134). Esses recursos tornam o texto mais atrativo para a criança por simularem a voz do contador de histórias.

Na literatura popular e na infantil, o apelo ao ouvinte, interlocutor ou leitor é muito frequente e vem da Antiguidade. Tal preocupação do autor gera diversos recursos estilísticos (exortação, invocação, sugestão, indução, fala imperativa) (...). Esse apelo à atenção do leitor ou ouvinte, para levá-lo a determinadas atitudes, é bem característico das narrativas tradicionais, nas quais há sempre

\footnotetext{
${ }^{220}$ As "tarefas de adivinhação" eram um possível modo através do qual o herói executava uma tarefa difícil no conto maravilhoso. (Propp, V., 1984, p. 35). Aqui o enigma é estendido ao leitor.
} 
alguém (avô, avó, tio, preto velho, velha ama etc.) que conta estórias para a criançada. (COELHO, N. N., 2000, p. 84)

Kharms entrelaça às narrativas processos variados afim de garantir adesão à leitura. Um dos recursos empregados com frequência é o diálogo, "uma das técnicas mais adequadas para atrair o pequeno leitor (ou ouvinte), exatamente porque a linguagem oral está mais perto de seu interesse do que a linguagem escrita" (COELHO, N. N., 2000, p. 81) e que, no conjunto dessa obra, permite à criança usar a imaginação para "encenar" as vozes das personagens, reproduzindo seus cacoetes e brincadeiras. No conto "Púchkin", por exemplo, a conversa entre um adulto e uma criança transmite, com linguagem bastante acessível, a história do grande poeta russo. Já em "Você esteve no jardim zoológico? ", encontramos um texto formado integralmente pelo jogo de perguntas e respostas sobre o leão, de modo que, os aspectos cômicos e a falta de entendimento entre os conversadores decorre do próprio diálogo:

— Você esteve no jardim zoológico?

- Estive.

— Viu o leão?

- Aquele de tromba?

— Não, esse é o elefante, o leão não é assim.

- Ah, é aquele de duas corcovas?

— Também não! Com juba. (p. 22)

As revistas infantis eram consumidas como um manual educativo e continham ensinamentos sobre o modo de vida soviético, de modo que, também faziam parte de um mecanismo de educação doutrinário que buscava suscitar respostas positivas dos leitores às ideias veiculadas em suas páginas.

Tchij e Ioj eram editadas mensalmente e essa periodicidade era aproveitada pelos editores para que as crianças interagissem no conteúdo das histórias. Assim, elas podiam enviar perguntas ou sugestões às personagens através de cartas. Isso ocorre com o famoso cientista Professor Trúbotchkin, possuidor de habilidades especiais dignas de um super- 
herói; a principal delas era a capacidade de responder a qualquer pergunta. Num dos contos da série, encontramos o apelo para o envio das cartas e, consequente, adesão à Revista Tchij:

- Agora todos os nossos leitores receberão respostas às suas perguntas. — Não, nem todos! - disseram o escritor Kolpakov e o ilustrador Tútin. APENAS AQUELES QUE ASSINAREM A REVISTA TCHIJ NO ANO DE 1934 (p. 110). (grifos nossos)

Esses procedimentos ampliam as formas de envolvimento com o texto literário, ao possibilitarem que a criança manifeste os efeitos da recepção da leitura para além do suporte da revista e atenda ao apelo do narrador usando sua voz para imitar o grito do ouriço, tente descobrir o nome dos sete gatos, adquira um novo número de sua revista preferida, envie uma pergunta ao Professor Trúbotchkin etc. Desse modo, o escritor ajuda a desconstruir uma falsa ideia da leitura enquanto ato meramente passivo, ao mesmo tempo que corresponde às expectativas educacionais soviéticas de acolher, dar voz e controlar a participação infantil.

Ao explorar elementos que lidam com a interatividade, Kharms propõe uma espécie de relação entre livro e leitor muito explorada sobretudo nos dias atuais quando os livros e brinquedos eletrônicos exigem a interferência direta do interlocutor.

\subsection{Da tradição à exigência soviética: a criança como personagem.}

Um dos apelos da política cultural daquele momento era de que as crianças pudessem trazer para a LIJ soviética suas próprias experiências advindas da nova organização social. Sabemos que elas sempre figuraram enquanto personagens na LIJ, desde o surgimento do gênero, principalmente por sua capacidade de despertar empatia dos ouvintes e leitores de mesma faixa etária. Na obra infantil kharmisiana, a personagem 
da criança ocupa lugar de destaque, atuando em diversos papéis através dos quais exerce sua capacidade imaginativa, participa de aventuras, quebra regras e revela seu mundo.

Kharms capta essa exigência pela participação infantil quando inclui em suas narrativas a categoria da criança-autora. Em "Um conto maravilhoso", encontramos, o pequeno Vânia empenhando-se na escrita de uma skazka (conto maravilhoso, em russo), ou seja, a exercer sua capacidade de autoria literária: "Pois bem, — disse Vânia, colocando um caderno em cima da mesa - vamos escrever um conto maravilhoso" (p. 122). Em contrapartida, apesar de seus esforços, o garoto não consegue propor temas originais, relacionados à realidade, por exemplo. Sua primeira intenção é a de escrever sobre um rei, depois sobre um bandoleiro e, por fim, sobre um ferreiro. Mas, todas as suas tentativas de escrita são frustradas por Liénotchka que, como uma pequena censora, responde-lhe: "Essa história já existe". Em seguida, ela conta uma história, supostamente existente, com as personagens pensadas pelo garoto, expondo, assim, a falta de originalidade das ideias do pequeno escritor e, ao mesmo tempo, revelando que as histórias infantis tradicionais são do conhecimento de todos.

As histórias começadas por Vânia e finalizadas por Liénotchka são provas das experiências de escrita coletiva realizadas, à época, na URSS. A autoria das personagens acaba sendo completada pelo próprio escritor, tendo em vista que, por fim, Vânia descobre-se a si próprio como personagem do "conto maravilhoso" que tentara escrever: "Vânia comprou Tchij, n. 7, e daí leu esta mesma estória que você acabou de ler" (p. 125).

A representação da autoria infantil também manifesta-se em outras duas histórias: “Certa vez comprei um lápis" e "Volódia estava sentado à mesa desenhando". As personagens dos respectivos contos, os garotos Bória e Volódia, aparecem no início das narrativas fazendo um desenho, que é uma forma de expressão muito característica da criança. Porém ambos acabam sendo interrompidos por conjunturas absolutamente 
extraordinárias. O primeiro é obrigado a matar uma barata, inseto rotineiro desde os tempos da antiga Rússia e que já figurava em romances de escritores como Gogol, por exemplo: "Uma vez, comprei um lápis, fui para casa e sentei para desenhar. Foi só querer desenhar uma casinha que, de repente, tia Sacha me chamou" (p. 77). A partir daí, sua tentativa de voltar a pegar no lápis não poderá ser retomada devido às circunstâncias externas à sua obra: "Na parede, perto daquele lugar onde eu estivera, havia mais um inseto bem estranho, só que era maior, do tamanho de um fósforo e meio" (p. 77). As exigências da vida cotidiana com suas necessidades práticas, nesse caso, impossibilitam a criação artística. Como consequência, o desenho, motivo inicial do conto, não é retomado pois surge um problema muito maior com o qual o garoto e a tia precisam lidar.

O segundo menino, Volódia, é atrapalhado por questões intrínsecas à sua própria produção, pois durante o processo de desenho, os gráficos ganham vida, à revelia do autor e passam a atuar de modo independente, como um quadro vivo. Esse evento fantástico, impede que o pequeno desenhista tenha poder de ação sobre sua obra:

Desenhou Volódia uma casinha, na janela da casinha desenhou uma pessoa de barba preta, ao lado da casinha desenhou uma árvore, ao longe desenhou um campo e uma floresta. Depois desenhou, perto da casinha, um arbusto e começou a pensar no que mais desenhar. Pensou, pensou e deu um bocejo. Depois bocejou outra vez e decidiu desenhar uma lebre embaixo do arbusto.

Volódia pegou o lápis e desenhou a lebre.

A lebre saiu bem bonita, com orelhas compridas e um rabinho fofo.

— Ei você aí! - pôs-se a gritar, de repente, o homem de barba preta da janela da casinha. - De onde apareceu essa lebre? Pois agora vou atirar nela com a espingarda! (p. 131)

Volódia assusta-se ao descobrir que o homem de barba, que pretende caçar a lebre é Karl Ivánovitch Shusterling, conhecido personagem de Tchij e $I o j^{221}$ - os pseudônimos

\footnotetext{
221 "O ouriço valente" e "No ano passado fui comemorar o ano novo", por exemplo, são assinados por "Vânia Mokhov". Já "Um conto maravilhoso" e "Volódia estava sentado à mesa desenhando" vemos a personagem de Karl Ivánovitch Shusterling. Abaixo, encontramos uma ilustração, com a historieta "Um tigre na rua", cuja autoria é atribuída a esta mesma personagem.
}

Figura 3: 
de Kharms, Vânia Mokhov e Karl Ivánovitch Shusterling, foram transformados em personagens pelo escritor. Ou seja, ambos eram conhecidos dos leitores em suas duas facetas: atuando e também assinando contos. Então, Volódia é levado para dentro de seu próprio “desenho animado", onde luta para defender sua criação: "Volódia saiu correndo atrás de Karl Ivánovitch” (p. 132).

Enquanto, Vânia, Bória e Volódia não saem do lugar-comum em suas produções artísticas - um "conto maravilhoso" e uma "casinha" - Fédia Kótchkin, em "O professor Trúbotchkin, sob o disfarce do famoso cientista, esbanja traços de experimentalismo em seu poema: “Querem que eu escreva para vocês alguns versos muito bons?”, pergunta o aprendiz de super-herói. Logo em seguida, lemos sua composição:

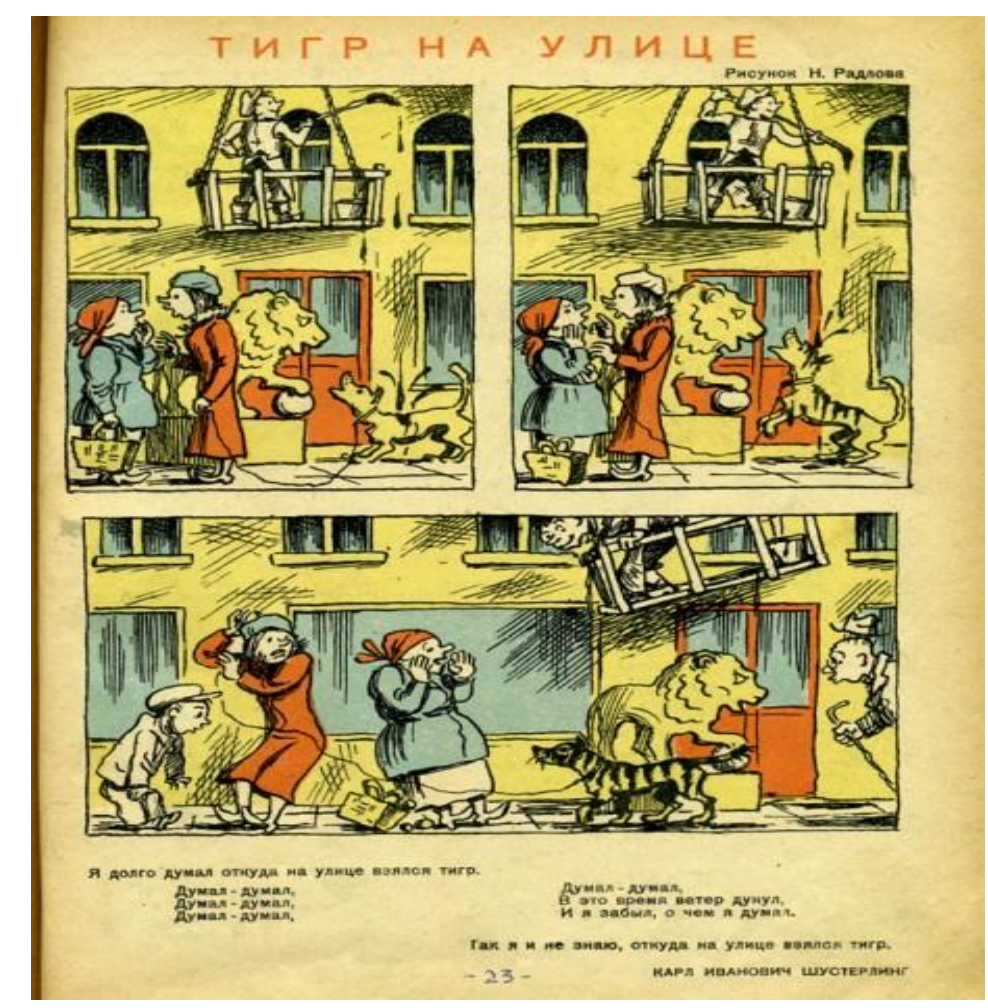

"Um tigre na rua"

(Fonte: http://zavjazhu.livejournal.com. Acesso em Dez. 2013)

Fiquei um tempão pensando em como apareceu um tigre na rua.

Pensei - pensei,

pensei - pensei,

pensei - pensei,

pensei-pensei,

Nessa hora, bateu um vento

e eu esqueci no que pensava.

Então, eu também não sei como apareceu um tigre na rua. (Karl Ivánovitch Shusterling) 
Jik, jik, jik

Foc, foc, foc,

Ric, ric, ric,

Chuk, chuk, chuk (p. 100)

Fédia, aliás, demonstra sua iniciativa ao ocupar lugar no resgate do Professor desaparecido. Qualidade também percebida nos protagonistas de “Como Kolka Pánkin voou para o Brasil e Pietka Erchov não acreditou em nada" que, mesmo contrariando toda a lógica, ingressam numa viagem fantástica ao país exótico.

Nos contos maravilhosos, por exemplo, são dadas ordens ou "proibições" às crianças que "passam a depender de si mesmas após a partida ou a morte dos pais." (Propp, 1984, p. 20) A “transgressão" põe fim ao bem-estar inicial da narrativa e abre espaço para as adversidades. Histórias desse tipo tradicionalmente tem sido contadas aos pequenos, afim de orientá-los a seguir os conselhos dos adultos para não serem acometidos por nenhum mal.

$\mathrm{Na}$ tradição oral, mesmo advertidas, as crianças necessariamente acabavam por incorrer na quebra do interdito através de atos, por vezes, involuntários. Entretanto, nos contos analisados neste trabalho, verificamos que as crianças quebram regras voluntariamente, traço que demonstra a atribuição de autonomia e capacidade de atuação dessa faixa da população, até aquele momento, considerada incapaz de manifestar opiniões sobre o mundo no qual se inseria. Essa capacidade de atuação conduz as crianças dos contos infantis de Kharms a desfazerem estereótipos e padrões de ação presentes em estruturas pré-concebidas.

Ilustramos a atuação infantil através da pequena Liénotchka que é orientada pela tia: "vou sair, você fique em casa e seja boazinha, não puxe o rabo do gato, não coloque semolina no relógio da sala de jantar, não se balance na lâmpada e não beba tinta química. Está bem?” (p. 79). Mas ao encontrar-se sozinha começa a destruir objetos e móveis: “Agora de uma mesa nós faremos duas! - pôs-se a cantar Liénotchka, dando 
machadadas na mesa" (p. 80). Sua atitude vai contra o que se espera de uma personagem típica dos contos infantis e foge à ideia de criança passiva. Em termos literários, contudo, Kharms acentua as ações da personagem através de atos repetitivos marcados pela agressividade.

\subsection{Personagens caricaturais}

Kharms cria caricaturas a partir da exacerbação de características físicas ou psicológicas das personagens. Ou seja, tornando seus gestos teatralizados e demarcados através do procedimento da repetição e do exagero de cacoetes ou biotipos.

Em geral, tais personagens não possuem nomes próprios e são chamados por seus traços mais marcantes. Nesse grupo encontramos a velhinha cuja principal marca é o alheamento às mudanças sociais de seu tempo. Ela vivia como nos tempos prérevolucionários: sozinha, tomando chá e escrevendo cartas ao filho. Ao sair de sua casa tendo em "suas mãos um guarda-chuva com cabo grande e brilhante, na cabeça um chapéu com lantejoulas pretas" (p. 61). Passa a ser questionada por todos: "Mas onde é que está com a cabeça, por acaso vive no mundo da lua?!” (p. 63)

Os escritores que são caricaturados pelo contraste físico: "No sofá estavam sentados um gordo e um magro" (p. 67). Pela gesticulação repetitiva: "O gordo contava algo para o magro e esfregava as mãos, já o magro, todo curvado, olhava para o gordo através dos óculos de armação clara e amarrava os cordões de suas botas" (p. 68). E pela capacidade de produção escrita de ambos:

— Pois é, — disse o gordo - escrevi uma história sobre um menino que engoliu uma rã. Uma história interessantíssima.

— Eu, por minha vez, não consigo imaginar nada para escrever. — disse o magro, enfiando o cordão pelo buraquinho (p. 68)

O exagero das proporções físicas também faz-se presente no "homem do tamanho de um baldinho" e no grande que foi encontrado deitado "com a cabeça num toco e ele 
era tão comprido que não dava para ver aonde as pernas terminavam”, personagens que aludem diretamente aos gigantes e anões dos contos maravilhosos e vêm ao encontro do gosto infantil:

A criança sente prazer em deformar a verdade geométrica, ampliando-a até o exageradamente grande ou reduzindo-a ao exageradamente pequeno. $\mathrm{O}$ colossal e o microscópico atraem-na como uma sugestão que o normal não possui; daí as clássicas histórias de gigantes e anões que divertem seus primeiros anos... (SOSA, J., 1978, p. 81)

São empregadas características caricaturais também nas descrições metaforizadas de Vássia que "aos 10 anos já era da altura de um armário e, aos 15, tinha crescido tanto para os lados que ficou parecido com um" (p. 115) e do Senhor Kurano "um velhinho japonês, pequeno e amarelado, parecido com um cogumelo todo enrugado" (p. 116). A imagem suscitada pelo contraste físico entre a robustez do primeiro e a fragilidade do segundo, reforça a surpresa do leitor quando a "força tremenda" do rapaz, apelidado de “Armário", é posta em xeque.

Ao mesmo tempo, Kharms confere ao senhor Kurano as características dos superheróis dotados de habilidades especiais, que se popularizariam através das histórias em quadrinhos. Isso só seria possível graças aos avanços tecnológicos da sociedade moderna, cujas pretensões estendiam-se, inclusive, para o aperfeiçoamento do corpo humano. "Nos rastros das descobertas científicas e invenções tecnológicas, a literatura descobre mundos e seres estranhos que ultrapassam de maneira inacreditável os naturais limites da condição humana" (COELHO, 1991, p. 245).

Nessa mesma linha de super-heróis, há o Professor Trúbotchkin, dono da capacidade de responder qualquer pergunta e Vânia Mókhin que "graças a uma fantástica invenção científica, Vânia ficou extraordinariamente forte” (p. 81). 
Através das caricaturas, Kharms renova em seus contos elementos típicos da estética do grotesco, cujo "aspecto essencial é a deformidade" 222 . As desproporções e contrastes físicos são recursos que conferem humor ao conto infantil, além de estimularem a imaginação do leitor.

\section{6 Paródia e atualização do gênero.}

Uma das formas utilizadas por Kharms para a atualização do gênero infantil, além de seu diálogo com a vida soviética, é a paródia de formas tradicionais como os contos da carochinha e os romances de aventura. De todo modo, muitas vezes, a relação da obra kharmisiana com estes modelos convencionais revela-se pela ruptura e quebra de paradigmas literários, característica que atualiza o conto infantil.

Os contos maravilhosos, geralmente, fazem parte das primeiras experiências literárias da criança pequena; além de possuírem linearidade, apresentam estrutura interna bastante sequencial. A configuração repetitiva dessas narrativas foi analisada por Vladímir Propp em seu trabalho "Morfologia do conto maravilhoso" (1928). Segundo ele, o conto maravilhoso possui um número básico de funções (ou invariantes) nas quais enquadram-se as personagens ou são executadas por elas ${ }^{223}$ - sendo a primeira o "afastamento" e a última o "casamento". Uma vez presentes numa determinada história, tais funções servem para o estabelecimento de um pacto entre narrador - ouvinte/escritor - leitor através do qual a narrativa se torna previsível.

\footnotetext{
222 cf. BAKHTIN, M., 2010, p. 38.

223 cf. Propp, V. Morfologia do conto maravilhoso. Trad. Boris Schnaiderman. Rio de Janeiro: Forense Universitária, 1984. O autor analisou a estrutura dos contos maravilhosos e constatou em todos eles o mesmo padrão narrativo. A partir disso, o teórico conseguiu divisar uma sequência de 31 funções, ou invariantes, capazes de mostrar o funcionamento dessas histórias. As funções e seus símbolos correspondentes são: afastamento $(\beta)$, proibição $(\gamma)$, transgressão $(\delta)$, interrogatório $(\xi)$, informação $(\zeta)$, ardil $(\eta)$, cumplicidade $(\theta)$, dano $(\underline{\mathrm{A}})$, carência $(\underline{\mathrm{a}})$, mediação $(\underline{\mathrm{B}})$, início da reação $(\underline{\mathrm{C}})$, partida $(\uparrow)$, primeira função do doador $(\underline{D})$, reação do herói $(\underline{E})$, fornecimento $(\underline{F})$, designação $(\underline{G})$, combate $(\underline{H})$, estigma $(\underline{I})$, reparação $(\underline{K})$, regresso $(\downarrow)$, perseguição $(\operatorname{Pr})$, salvamento $(\operatorname{Rs})$, chegada $(\underline{\mathrm{O}})$, pretensões infundadas $(\underline{\mathrm{L}})$, tarefa difícil $(\underline{\mathrm{M}})$, realização $(\underline{\mathrm{N}})$, reconhecimento $(\mathrm{Q})$, desmascaramento $(\underline{\mathrm{Ex}})$, transfiguração $(\underline{\mathrm{T}})$, castigo $(\underline{\mathrm{U}})$, casamento (W).
} 
Em termos gerais, nas narrativas convencionais, a unidade de ação era atingida a partir da obediência à ordem tradicionalmente composta pelo início da ação, desenvolvimento, clímax e desenlace. Essa sequência podia ser verificada tanto em romances, quanto em novelas e contos. Embora nesses últimos houvesse uma condensação maior de todos os elementos, de modo que, toda a trama da história girava sob a expectativa de um acontecimento principal, de um auge que funcionava como divisor de águas entre o nó e o desfecho dos fatos. Essa estrutura, estabelecida enquanto paradigma composicional desde a antiguidade, perdurou, guardadas as devidas proporções, ao longo da história literária até ser posta em xeque por escritores como Anton Tchékhov, no fim do século XIX. (GOTLIB, N. B., 2003, p.47)

Os contos literários tradicionais destinados à criança, em geral, preservam uma estrutura tradicional com típicos começo, meio e fim, que acaba sendo uma forma mais didática ao leitor iniciante, por permitir a percepção do modo como as ações se intensificam gerando enigmas, suspense, tensão, até serem concluídas. Em geral, as peripécias do enredo conduzem as personagens ao final feliz, com resolução dos conflitos encontrados. O desmembramento das partes constituintes do conto maravilhoso, por Propp, revela que sua estrutura possui caráter repetitivo e previsível, apesar diversidade de exemplares existentes nas mais variadas literaturas.

Mesmo havendo adequação de personagens e cenários para o ambiente soviético, Kharms brinca com essa previsibilidade dos contos tradicionais ao recuperar suas características e funções em seus contos modernos. "Charms plays with the most basic fairy-tales conventions in several of his stories [sic]". (TUMANOV, L., 1993, p. 7)

Segundo Tzvetan Todorov (2011, p. 138), “uma narrativa ideal começa por uma situação estável que uma força qualquer vem perturbar”. Nos contos maravilhosos, por exemplo, o início da história é marcado por uma curta "situação inicial": "Enumeram-se 
os membros de uma família, ou o futuro herói (por exemplo, um soldado) é apresentado simplesmente pela menção de seu nome ou indicação de sua situação”. (Propp, V., 1984, p. 19)

As formas convencionais de início da narrativa são imitadas por Kharms tanto com começos que imitam contos da carochinha "certa vez", "era uma vez" e "numa aldeia", quanto há apresentação dos protagonistas e espaço: "Na Casa da Criança 124" (p. 24); "Na rua Kossobôkhaia, no prédio número 17, vivia uma velhinha” (p. 61), "Era uma vez um homem chamado Fiódor Fiódorovitch Kolpakov" (p. 111), "Volódia estava na festa de ano novo" (p. 82) etc. Através desses procedimentos narrativos, o leitor tem a impressão de estar diante de uma história "tradicional", de modo que, a narrativa kharmisiana reveste-se de uma aparência clássica.

Entretanto, Kharms frustra as expectativas e subverte o andamento convencional do gênero, através do modo como trabalha os elementos interiores da narrativa: as peripécias servem para a ridicularizar os protagonistas, ao invés de consagrá-los heróis; as tarefas difíceis são substituídas por problemas matemáticos; nem sempre há o estabelecimento de um clímax e o final parece não solucionar os conflitos das personagens. A seguir, abordaremos as principais funções morfológicas dos contos maravilhosos presentes nos contos e os modos como Kharms lida com esses elementos tradicionais:

Em "Sobre como a velhinha...", encontramos funções da morfologia do conto de fadas: carência (a personagem principal precisa de tinta para escrever), afastamento (depois que o filho foi embora e o marido morreu); início da reação (ela decide sair em busca de tinta), partida (vai para a cidade), tarefas difíceis (onde enfrenta obstáculos e chega até a editora). Vitória (sua história sensibiliza um dos escritores), reparação (consegue tinta). 
O enredo desse conto possui início, meio e fim bastante demarcados, configuração que dá à história uma aparência tradicional. Contudo, as aventuras da velhinha são preenchidas por elementos narrativos modernos. Em primeiro lugar, as tarefas difíceis encontradas por ela são todas impostas pelo universo real e contemporâneo: dificuldades de comunicação, inabilidade para transitar na cidade grande e desconhecimento da modernidade citadina. Ou seja, a personagem não transita por um mundo mágico com obstáculos extraordinários, mas enfrenta o ambiente hostil da metrópole:

— Saia da frente! - grita o zelador jogando água.

A velhinha foi para a esquerda e o jorro para a esquerda.

A velhinha foi mais do que depressa para a direita e o jorro atrás dela.

— Onde está com a cabeça, — grita o zelador — vive no mundo da lua? Não vê que estou a molhar a rua!

A velhinha acenou com o guarda-chuva e seguiu adiante (p. 62).

— Tinta? - ele repetiu a pergunta.

- É, tinta.

- Tinta?

- Tinta.

— E de peixe não precisa?

- Não.

- Quer dizer que é tinta?

- É.

- Mas onde é que está com a cabeça, por acaso vive no mundo da lua?! - disse o rapazote (p. 63).

Em seguida, o tom jocoso é intensificado a cada peripécia e contribui para captar a atenção do leitor. Mas ao contrário do conto maravilhoso, onde as dificuldades revelam a bravura do herói, aqui eles revelam a fragilidade da velhinha que é ridicularizada. Desse modo, até sua chegada à editora, onde enfim consegue a almejada tinta, seu percurso é permeado pelo humor kharmisiano que permite à protagonista enfrentar situações constrangedoras:

Mas o homem montado no asno não escutou; não deve ter ouvido o que a velhinha lhe falava e levantou uma espécie de tubo com uma ponta estreita e outra larga feito uma boca de corneta. Apoiou na boca a ponta estreita, daí pôs-se a gritar de lá bem na cara da velhinha, tão alto que dava para ouvir a sete léguas (...) (p. 64) 
O universo do conto maravilhoso possui mecanismos que ajudam o herói na execução de suas funções e superação das dificuldades, através do provimento de “auxiliares mágicos" que podem ser um objeto (animal) ou um ser. "Acontece com frequência que, sem preparação alguma, diversos seres mágicos aparecem de repente, são encontrados pelo herói no caminho, oferecem sua ajuda e são aceitos como auxiliares”. (PROPP, V., 1984, p. 28).

Em sua trajetória, a velhinha recebe ajuda "da boa alma" que a ajuda a atravessar a rua e, por fim, “do escritor magro", doador da tinta. Seus auxiliares, porém, são humanos e estão fora do campo da magia. Desse modo, Kharms situa a reparação da carência no âmbito da realidade e abre uma nova possibilidade de resolução para a situação de falta de tinta, baseada na troca e auxílio mútuo. Tendo em vista que, a velhinha ganha a tinta, mas, em contrapartida, fornece sua própria história enquanto material literário: “Conta para nós sobre como você comprava tinta, nós vamos escrever um livrinho sobre a senhora e lhe daremos tinta" (p. 69).

Em "Olha, Liénotchka, - disse a tia...", o enredo é desencadeado exatamente como nos contos maravilhosos: afastamento (a tia sai de casa), proibição (proibindo sua sobrinha de jogar semolina no relógio). Transgressão (a pequena garota resolve destruir o mobiliário e o conto acaba em meio à destruição).

A história ilustra bem o tipo de desmonte das formas tradicionais empreendido por Kharms, através de sua obra infantil. O início da leitura, dá indícios de a história possui um desenrolar tradicional, porém isso não acontece. Verificamos que, Liénotchka não demonstra receio de atrair um mal externo, de modo que, as forças mágicas do mundo maravilhoso não encontram espaço no enredo. A atitude destruidora choca o leitor e confere ao conto um final fora dos padrões. 
Outro conto que dialoga com a estrutura do conto maravilhoso é "Os dezessete cavalos". Nessa história, três irmãos, herdeiros de dezessete cavalos, têm a tarefa de dividir os animais nas frações citadas no testamento do pai.

Ao filho mais velho deixo $1 / 2$ da herança, ao filho do meio deixo $1 / 3$ da herança $\mathrm{e}$ ao filho mais novo deixo $1 / 9$ da herança.

E quando esse homem veio a falecer, sobraram 17 cavalos de tudo o que havia e nada mais. Os filhos puseram-se a dividir os 17 cavalos entre si (p. 36).

Entretanto, o cumprimento da vontade paterna não acontece, a princípio, pois o resultado da conta não é exato e os rapazes não podem dividir os cavalos ao meio: "Porque não é possível dividir 17 nem por 2, nem por 3, nem por 9” (p. 36). Constatamos, as seguintes funções: afastamento (morte do pai), carência (deixa irmãos sem herança), partida (o irmão caçula sai em busca de ajuda), regresso e tarefa difícil (em seu retorno precisam solucionar o problema lógico-matemático).

A chamada "tarefa difícil" 224 que diz respeito aos obstáculos pelos quais o herói dos contos maravilhosos necessariamente passava, afim de cumprir sua missão. Segundo Propp (1984, p. 34), este recurso é um dos “elementos favoritos do conto maravilhoso" e muito explorado pela literatura infantil, pois prende a atenção do leitor à narrativa. Contudo, Kharms retirar a questão do desafio ou tarefa difícil de dentro do universo maravilhoso transferindo-o para um enigma matemático estendido ao leitor, que também é estimulado a desvendar o segredo do cálculo.

Os irmãos encontram o sábio Rassudilov que assume uma das funções pertencente ao auxiliar e supera o desafio proposto pela história. Segundo Propp (1984, p.46), “o auxiliar também pode cumprir funções que são específicas do herói.” Contudo, a figura de Rassudilov - nome que significa "conciliador"225 - é estranha aos contos de magia,

\footnotetext{
${ }^{224}$ Função ou invariante da morfologia dos contos maravilhosos.

225 O verbo russo "rassudit” (рассудить) significa julgar, conciliar.
} 
por não se tratar de um auxiliar mágico típico, mas de uma pessoa comum capaz de fazer cálculos. Assim, sua ação permanece restrita aos âmbitos cognitivo e ordinário.

O homem os escutou e disse: "Peguem o meu cavalo, assim vocês terão 18 cavalos e poderão dividir tranquilamente." Os irmãos começaram a dividir os 18 cavalos.

O mais velho pegou $1 / 2-9$ cavalos,

o do meio pegou $1 / 3$ - 6 cavalos

e o caçula pegou $1 / 9$ - 2 cavalos.

Os irmãos somaram seus cavalos $9+6+2$, que dá 17 cavalos. Já Ivan Petróvitch montou no seu $18^{\circ}$ cavalo e pôs-se a fumar seu cachimbo (p. 37).

No conto "Em primeiro e em segundo lugar", um grupo de quatro personagens Pietka, o homenzinho, o homem comprido e o narrador-personagem - ingressa numa jornada sem destino certo. Em seguida, o grupo depara-se com uma sequência de desafios: montar no asno, cruzar um rio e encaixar-se no automóvel, de uma maneira que "todos fiquem bem”. As funções que se destacam são partida e tarefa difícil.

Nessa história, o leitor é, novamente, atraído para o universo maravilhoso, tendo em vista que entre seus atores encontramos um homem minúsculo "do tamanho de um baldinho" e um gigante. Contudo, algumas das tarefas difíceis e dos auxiliares, presentes no enredo, estão fora do universo da magia.

À medida que as personagens seguem caminho encontram obstáculos que estão relacionados ao gosto infantil pela proporção entre objetos, comparação entre as formas e exercícios de lógica. Logo de início, a principal dificuldade é a adequação dos passos longos do homem grande aos miúdos do restante. Questão resolvida da seguinte maneira: "O homem comprido acomodou o homenzinho no seu ombro, pegou-nos debaixo dos braços e seguiu em frente" (p. 32).

Em seguida, o grupo depara-se com uma sequência de desafios: montar no asno, cruzar um rio e encaixar-se no automóvel, de uma maneira que "todos fiquem bem". Em cada um desses momentos, a história propõe uma espécie de quebra-cabeça para o leitor. 
Tendo em vista que, as personagens possuem diferentes tamanhos, mas precisam entrar num espaço pequeno e delimitado. Ou seja, numa fôrma.

A criança leitora é, indiretamente, convidada a pensar num jeito de acomodá-las:

Eu e Pietka nos sentamos ao volante, pusemos o homenzinho sobre o farol, mas não dava para acomodar o homem comprido, o asno e o barco juntos de jeito nenhum no automóvel. Colocamos o barco no carro, dentro do barco o asno e tudo estaria certo, se o homem comprido não estivesse sem lugar. Nós pusemos ele dentro do barco, mas o asno ficou sem lugar. Colocamos o asno e o homem comprido no automóvel, aí não havia nenhum lugar para o barco (p. 33)

O primeiro conjunto de auxílios encontrados pelo caminho (asno, barco e automóvel) são desprovidos de capacidades extraordinárias e funcionam apenas dentro de suas esferas reais de atuação. Nesse jogo de encaixe, algumas opções são testadas até que a solução é alcançada: "Sentamos o homem comprido no automóvel, colocamos o asno em seus joelhos, demos o barco para ele segurar. (...) Pus o motor em marcha e nós seguimos" (p. 33) A resolução de tais problemas é fundamental para que as personagens prossigam viagem. Dessa forma, ao retirar a atuação de forças extraordinárias, Kharms dá acabamento moderno às tradicionais peripécias, apoiando-se na lógica para a resolução das dificuldades.

Nesse conto, Kharms emprega um modo inusitado de iniciar a ação, pois a mediação inicial com o leitor é feita obedecendo-se à enumeração ordenada de eventos: "Em primeiro lugar". Assim, no lugar do estabelecimento de uma situação inicial tradicional, o narrador-personagem conta sua história seguindo a disposição dos números ordinais: "em segundo lugar, em terceiro..." e assim sucessivamente. Essa contagem é retomada, de tempos em tempos, para estabelecer o nexo causal entre as pequenas cenas que compõem o enredo.

Desse modo, há ocasiões em que o escritor abandona essas formas mais convencionais de introdução do conto e entabula suas narrativas sem fornecer indícios acerca da personagem, do espaço ou do tema. Ou seja, sem estabelecer a chamada 
"situação inicial". Com isso, o escritor toma o leitor de surpresa, pois a história começa de chofre, sem informações caracterizadoras das situações e personagens.

Ao lermos, de pronto, na primeira frase: "Ficou decidido que, logo após terminar a aula de alemão, todos os índios deveriam se reunir no corredor" (p. 52) ou "Kolka Pânkin decidiu dar uma volta em algum lugar distante” (p. 38), percebemos que não há estabelecimento de um pacto de leitura prévio com vistas a preparar o leitor para a narrativa. O estranhamento criado pelo começo não convencional dá lugar à expectativa pelo novo, já que o leitor não sabe o que esperar da narrativa, por sua estrutura fugir do habitual.

Outro elemento componente dos enredos tradicionais e bastante importante na LIJ é o clímax. Ou seja, o ponto culminante da história. Nos contos maravilhosos, o desenvolvimento desse momento é descrito morfologicamente por Propp pela sequência de funções: “combate”, “estigma”, "vitória” e "reparação”. Por meio desta última "o conto atinge o ápice” (PROPP, V., 1984, p. 31). Assim, nas histórias infantis clássicas, esse auge narrativo, muitas vezes, começa com o enfrentamento (combate) entre herói e antagonista, em suas diversas formas: luta, jogo, competição etc.

De acordo com Gotlib (2003, p. 93), o clímax pode ser resumido da seguinte forma: "momento decisivo do enredo, em que se atinge o ponto máximo de tensão (conflito) e que traz ou anuncia o desfecho ou a resolução do conflito".

Kharms faz uma espécie de releitura desses modos de confronto, aproveitandose desse recurso tradicional para incrementar a trama, em contextos inusitados.

É o que ocorre em “O quebra-ossos”, quando Vássia chega à escola de jiu-jitsu do senhor Kurano: partida (Vássia muda-se para o Japão), combate (onde irá aprender a arte marcial). Marca e regresso (fica traumatizado com a experiência e retorna à URSS). 
O episódio do confronto entre mestre e aprendiz, intensificado através do detalhamento dos movimentos corporais durante a aula, não chega a ser um combate real, tratando-se de um teste aplicado pelo professor. Desse modo, Kharms apresenta em contexto moderno, a tradicional função do “combate”, sinalizada por Propp:

O senhor Kurano agarrou Vássia pelos braços e o puxou para o lado. Vássia passou uma perna para a frente e sentiu-se, novamente, em posição de equilíbrio, mas foi só querer segurar o senhor Kurano que recebeu, de novo, um golpe no flanco e vendo-se, de repente, de ponta-cabeça, relou os pés no teto e passou por cima do japonês tornando a se espatifar no chão.

Vássia saltou, olhando assustado ao redor e, em seguida, voou em volta do japonês e foi parar deitado no chão.

Totalmente perdido, Vássia levantou-se de um salto e disparou para a porta. (p. 120)

O combate adquire, então, contornos "realistas" e socialmente aceitáveis, por estar inserido numa aula de luta, de modo que, não há um antagonista típico. A expectativa do leitor é quebrada, pois Vássia não revela coragem ou heroísmo e o velho senhor Kurano vira o herói, a despeito de qualquer expectativa, vence a luta devido ao seu conhecimento técnico dos movimentos da luta. A cena, como um todo, é permeada pela comicidade. Vássia perde a briga, sem que suas "marcas” garantam "vitória” ou "reparação".

A literatura russa clássica já havia fornecido exemplos dessa perda de prestígio do herói. Segundo Eleazar Meletínki (2002, p. 176 - 177):

No que se refere ao arquétipo do herói, Púchkin se inclina antes para o seu destronamento, que em graus diferentes é aplicado às formações atuais, diferentes e como regra românticas, do caráter heroico. (...) Esta linha de destronamento será seguida e concluída por outros escritores russos, em particular por Dostoiévski.

Após ter perdido sua única oportunidade de sucesso, a trajetória do jovem lutador "vagaroso de raciocínio" é introduzida na realidade soviética, onde ele se enquadra como máquina do Estado, ao contrário de qualquer expectativa de triunfo: "Seu trabalho consiste em arrastar ônibus quebrados de um lugar para outro" (p. 120) Se o universo 
maravilhoso confere vida aos objetos inanimados, realidade moderna, por sua vez, coisifica as capacidades humanas e incorpora o indivíduo às engrenagens do sistema.

O anticlímax kharmisiano é levado ao extremo no invento de Astatúrov, em "Um atrás do outro". Nesse conto, um novo jogo de tabuleiro é apresentado, mas, para surpresa do leitor, o brinquedo foge totalmente ao esperado. Tendo em vista que, o passatempo consiste em movimentar peças sem que haja qualquer tipo de disputa, competição ou possibilidade de vitória, ou seja, há ausência de enfrentamento. Algo absolutamente insólito. Dessa maneira, o escritor insere na narrativa elementos de humor e absurdo.

— Isso não importa. — disse Astatúrov - Agora explicarei ao senhor como se joga esse jogo. São dois jogadores. Primeiro, eles colocam as peças nos lugares. As figuras amarelas nos quadrados amarelos, as azuis nos azuis.

- E depois? - perguntou o redator.

- Depois, - disse Astatúrov — os jogadores começam a mover as figuras. O primeiro move o samovar amarelo, o segundo, o samovar azul. Aos poucos, as figuras caminham umas ao encontro das outras e, enfim, trocam de lugar.

- E o que vem depois? - perguntou o redator.

— Depois, — disse Astatúrov — as figuras caminham de volta na mesma ordem.

— Mas e daí? - perguntou o redator.

—É tudo. — disse Astatúrov solenemente (p. 89).

A literatura para crianças tem priorizado o tradicional final feliz com resolução de conflitos, vitória do herói e banimento do mal. Após sua adaptação para a literatura infantil, os contos da carochinha também passaram a apresentar finais edulcorados por enlaces amorosos e pelo banimento do mal. "O consolo é o maior serviço que o conto de fadas pode prestar à criança: a confiança em que, apesar de todas as tribulações que tem de sofrer (...) não apenas ele terá sucesso, como as forças do mal se extinguirão e nunca mais ameaçarão a paz de sua mente" (BETTELHEIM, B., 2002, p. 160).

Kharms, por seu turno, dispensava personagens ilusórios e libertava a literatura infantil do protocolo do final feliz, porque a realidade impunha um comportamento apto ao trabalho,, ao sacrifício pessoal e ao esforço coletivo. 
Por vezes, os contos acabam por dar margem à continuidade da história: "Saímos da cidade e prosseguimos, mas para onde fomos e o que lá aconteceu, já é uma outra história" (p. 35). À sugestão de um desafio ao leitor: "Quem sabe você possa me dizer para onde se escafedeu meu querido Karl Ivánovitch?” (p. 134). Em suspense, sem resolver questões apresentadas: "Só que isso não é escorpião. Primeiro, como um escorpião poderia parar aqui? Segundo, escorpiões não pulam” (p. 78) etc. Mas o final clássico dos contos de fadas, marcado pela função morfológica do "casamento", por exemplo, não acontece nas histórias do escritor. Percebemos isso como um dos desdobramentos da sociedade soviética, que não pretendia enfatizar literariamente a constituição de famílias burguesas tradicionais.

Por meio da subversão das formas clássicas, a obra infantil de Kharms ganha características bastantes modernas. A partir de narrativas lineares e paródicas, o escritor soviético rompe com o didatismo das formas, tradicionalmente usado na LIJ, e confere aos contos um acabamento semelhante à montagem; técnica "que rompe com a aparência de totalidade". (BURGER, P., 2012, p. 132)

O caráter independente das partes constituintes, típico das vanguardas, foi apontado por Bertold Brecht: “(...) a sequência da fábula é, aqui, descontínua; o todo unitário consiste de partes autônomas que, imediata e respectivamente, podem - devem, na verdade - ser confrontadas com os eventos parciais que lhes são correspondentes na realidade”. (BRECHT, B. apud BURGER, P., 2012, p. 162)

Outra característica da obra infantil de Kharms é a ausência de conteúdo simbólico típica do conto maravilhoso tradicional, que inviabiliza uma possível leitura psicológica dos elementos do enredo ${ }^{226}$. Nos contos da carochinha a linguagem é simbólica encontra

\footnotetext{
${ }^{226}$ A simbologia lida com arquétipos e, no caso da sociedade soviética, a nova realidade ainda estava a elaborar seus modelos arquetípicos.
} 
ressonância no inconsciente do pequeno leitor, pois o conteúdo metafórico do texto aborda tabus e assuntos que, em geral, não podem ser tratados de modo pragmático pelas crianças.

Os detalhes presentes nas obras clássicas recebem especial atenção, pois através deles a criança capta o conteúdo subliminarmente veiculado e chega "a solução de suas próprias turbulências emocionais" (CADEMARTORI, L, 2010, p. 43) Assim, por exemplo, segundo Bruno Bettlheim (2002, p. 217), as três gotas de sangue que pingam do dedo da rainha, em "Branca de Neve", "preparam a criança para aceitar um acontecimento conturbador: o sangramento sexual, como na menstruação, e posteriormente na relação sexual quando o hímen é rompido".

A obra kharmisiana é, entretanto, desprovida dessa simbologia psicológica. Os poucos detalhes inseridos ao texto, caracterizadores de espaços e personagens, como a menção a "uma longa escada dupla e dobrável" ou a "um guarda-chuva de cabo grande e brilhante", por exemplo, revelam mais sobre a tecnologia dos utensílios de trabalho e o caráter supérfluo do brilho ornamental, à época. O psicologismo dos contos maravilhosos acaba sendo substituído pela repetição exagerada de gestos mecânicos.

Nesse sentido, Kharms investe numa espécie de descrição dos movimentos, que são gradativamente expostos ao leitor, traço que rompe com o imobilismo das cenas conferindo-lhes um andamento bastante cinematográfico. A repetição permite que o leitor acompanhe os deslocamentos espaciais realizados pelas personagens. No trecho abaixo, podemos observar que as ações se repetem e são recontadas pelo escritor que acrescenta poucas alterações a cada reincidência:

O bandoleiro praguejou e pulou para cima do cavalo de novo, mas errou o cálculo outra vez, cruzou para o outro lado e caiu no chão. Levantou-se, brandiu o punho, foi montar no cavalo de novo, atravessou por cima do bicho e aterrissou no chão. Nisso, o bandoleiro sacou a pistola do cinturão, disparou para o al to e tornou a pular no cavalo, mas com tanta força que, novamente, atravessou por cima dele e estatelou-se no chão. Então o bandoleiro arrancou o gorro da cabeça, 
pisoteou-o e tornou a pular no cavalo, atravessou por cima dele outra vez, estatelou-se no chão e quebrou uma perna. (p. 123) (grifos nossos)

O modo como foi construída textualmente a tentativa de fuga do bandoleiro, demonstra a plasticidade explorada pelo escritor, que busca remeter o leitor às cenas do cinema mudo, nas quais a ausência da voz fixa o expectador nos gestos teatrais dos atores. Essa aproximação com a linguagem cinematográfica estava relacionada à proposta OBERIU, no que diz respeito à hibridização da literatura com outras formas de arte. No exemplo abaixo, a repetição confere, novamente, aspecto quase que concreto à expressão da personagem:

De susto, a velhinha até deixou o guarda-chuva cair. Ela levantou o guarda-chuva, mas as mãos tremiam tanto de medo que o guarda-chuva tornou a cair.

A velhinha apanhou o guarda-chuva, segurou-o com mais força e bem depressa, mais que depressa, seguiu caminho (...) (p. 65)

Verificamos, então, que Kharms incorpora, aos seus contos, recursos linguísticos capazes de imitar as linguagens do teatro e do cinema. Entretanto, enquanto as pantomimas realizadas pelos atores no palco ou na tela prescindem de palavras e são suficientes para comunicar à plateia a ideia de uma cena, a obra literária precisa reproduzir com procedimentos textuais essa gesticulação corporal:

Vássia já estava levantando a mão para acertar o golpe e, de repente, foi como se ele próprio tivesse recebido uma descarga elétrica no flanco. Vássia soltou um grito e agarrou o senhor Kurano pelo pescoço. Mas o senhor Kurano deu um mergulho para baixo. Vássia, de repente, perdeu o equilíbrio, passou por cima do japonês e espatifou-se no chão.

- Ah! - gritou Vássia e ficou de pé. Mas, no mesmo instante, levou um golpe nas pernas e tornou a perder o equilíbrio.

O senhor Kurano agarrou Vássia pelos braços e o puxou para o lado. Vássia passou uma perna para a frente e sentiu-se, novamente, em posição de equilíbrio, mas foi só querer segurar o senhor Kurano que recebeu, de novo, um golpe no flanco e vendo-se, de repente, de ponta-cabeça, relou os pés no teto e passou por cima do japonês tornando a se espatifar no chão.

Vássia saltou, olhando assustado ao redor e, em seguida, voou em volta do japonês e foi parar deitado no chão (p 120.)

Observamos que, a cena acima ilustra bem como o escritor reconstitui textualmente o gestual coreográfico de suas personagens. Efeito conquistado pelo 
aproveitamento de locuções verbais (querer segurar; foi parar deitado), repetição de verbos (espatifar, agarrar, levantar, passar etc), especificação de membros corporais (pescoço, pernas, braços, flanco) e exploração de substantivos, advérbios e adjetivos relativos ao espaço (lado, cima, baixo, ponta-cabeça etc).

A fábula também é retomada e subvertida pela pena kharmisiana. Esse diálogo fica explícito através da presença de seres tipicamente fabulares nos contos, como os animais antropomorfizados, indiscutivelmente pertencentes ao âmbito do fantásticomaravilhoso. Sobre estes, Jesualdo Sosa (1978, p. 124) esclarece:

Amiúde, também são personagens os animais que se dotaram de alma, ou os objetos igualmente animados: vassouras, palhas, varinhas, espelhos, lanternas etc. O fundamental nessas personagens, diz Buhler, é 'que são vistos como tipos e, em geral, têm apenas uma qualidade relevante elevada ao máximo'. As qualidades físicas ou morais são nítidas em cada personagem, como dissemos antes: personificam orgulho, modéstia, coragem, covardia, feiura, beleza, bondade, maldade.

Há contos em que os bichos aparecem antropomorfizados, como é próprio do imaginário infantil, e também interagindo com personagens humanas. Por isso, Platon conversa com uma garça e com um gato, em “Era verão, o sol brilhava...”:

Em plano ainda inferior, na escala os contos de fadas para a criança bem pequena, as coisas não são inteiramente reais ou indiferenciadas. Uma cabaça é uma carroça, um bicho-papão é um leão ou uma ratazana, um camundongo é um lacaio, Ulisses pode ser um jovem ou um velho, Minerva é deusa e mortal, Proteu é qualquer coisa que a criança deseje, um gato fala como homem, botas mágicas adaptam-se a todos os pés (SOSA, J., 1978, p. 36)

Contudo, o uso aqui feito desses seres do mundo da imaginação difere de Esopo ou de La Fontaine onde encarnavam vícios e virtudes afim de transmitirem uma lição moral. Em Kharms, eles são convocados à propaganda das próprias publicações, ao intertexto e ao antimoralismo bem-humorado.

O “ouriço" e o "pintassilgo", por exemplo, são uma alusão clara aos nomes das revistas para as quais o escritor trabalhava, por isso podem ser considerados como uma 
espécie de personagens-título, com destacada presença nos contos desta coletânea. A presença desses animais, em específico, parece se enquadrar dentro de uma estratégia propagandística para atrair leitores motivados a adquirir as publicações de Tchij e Ioj. Elas figuram, por exemplo, em “A lebre e o ouriço", "Você esteve no jardim zoológico?" e "O ouriço valente". Assim, as crianças liam tais histórias e, ao mesmo tempo, guardavam os nomes de seus almanaques preferidos.

No conto "Em primeiro e em segundo lugar", o escritor estabelece diálogo com Krylov, ao recrutar as personagens e a cena de sua "O Elefante e o cachorrinho" ${ }^{227}$. Nos versos desta conhecida fábula, o elefante, rodeado de gente, atravessa um vilarejo, mas mantem sua marcha contínua e tranquila mesmo quando afrontado pelos latidos de um cachorrinho. Este, questionado pelos outros cachorros sobre sua atitude, responde que, agindo dessa maneira, pode ser reconhecido entre os maiores valentões sem nunca ter entrado numa briga; basta que os demais alardeiem sua força e coragem ao provocar um elefante.

A intertextualidade entre o conto de Kharms e a fábula russa, que fazia parte do repertório infantil sendo recitada às crianças e aprendida nas escolas, é prontamente suscitada quando esses animais entram em ação no meio do enredo de "Em primeiro e em segundo lugar": "Olhamos pela janela, vimos na rua um elefante e, atrás dele, um bando de gente se amontoava. Bem nos pés do elefante corria um cachorrinho latindo com toda força, mas o elefante vinha calmamente, não dava a menor bola para ninguém" (p. 35). Entretanto, o cachorrinho e o elefante krylovianos aparecem sob a ótica de outras personagens, não enquanto animais antropomorfizados típicos das fábulas, sendo integrados à ação como meios de transporte para o homenzinho e para o homem comprido: "Veja, — o homenzinho disse ao comprido — há um elefante aqui para você.

\footnotetext{
227 A fábula "O elefante e o cachorrinho" (Слон и Моська) também ganhou uma versão em desenho animado com direção de Pantaleimon Sazónov, em 1941.
} 
Monte e vá". — "E você pode montar no cachorrinho. É bem do seu tamanho" — disse o homem comprido (p. 35).

Por meio dessa referência, o autor soviético alude à subjacência da tradição literária russa nas obras de sua própria época, ao fazer das personagens do fabulista suas também. Nesse ponto recordamos um traço da obra de Kharms investigado por Lima (2001, p. 83) para quem esse escritor manifesta em seu trabalho "concomitância entre passado, presente e futuro".

Além do cachorro e do elefante, há outros animais que, na LIJ tradicional, possuem uma conotação simbólica: a raposa, representa a esperteza; o leão, a realeza; a lebre, velocidade e astúcia; o gato, a sabedoria etc. De acordo com Propp (1984, p. 9), “o conto maravilhoso atribui com muita facilidade as mesmas ações aos homens, aos objetos e aos animais.” Entretanto, na obra de Kharms, estes animais aparecem, em geral, desvinculados de suas características típicas, pois não veiculam ideias morais. Ou seja, perdem seu caráter exemplar.

Assim, o desmonte das convenções literárias tradicionais é feito, em geral, por meio de um mecanismo que, primeiramente, cria a impressão de que um gênero familiar será usado. Mas, logo em seguida, acontece a destruição dessa hipótese. (TUMANOV, L., 1993, p. 11) Ou através do procedimento da repetição que desmascara os métodos de composição, expondo a estrutura da obra e seu modo de funcionamento.

Numa paródia, “Certa vez, o leão, o elefante, a girafa, a rena, o avestruz, o alce, o cavalo selvagem e o cachorro...” (p. 70). A enumeração de tantos animais para uma suposta fábula já causa estranhamento no leitor, além disso alguns deles como a girafa e o alce, parecem deslocados do universo exemplar. Em seguida, eles entram numa disputa para ver quem corre mais rápido ao redor de um lago. O leão, no início da corrida, decide parar para descansar: "O leão deu alguns pulos, cansou-se e foi descansar debaixo das 
palmeiras" (p. 70). Numa atitude que parece reforçar sua simbologia de "rei dos animais", também relacionada ao ócio e à preguiça.

Mas, em seguida, os demais competidores acabam envolvidos numa série de trapaças, bufonadas e desditas que modificam a ação e promovem um final imprevisível com a vitória da rena e do cavalo selvagem. Entretanto, a subversão da característica principal da fábula acontece dada a ausência de ensinamento. De modo que, a exemplaridade, presente no universo fabular com os quais dialoga, é substituída pela jocosidade que vem à tona nas atitudes dos animais. Dessa maneira, tais personagens deixam de representar ou ensinar ideias e conceitos morais para atuarem em cenas repletas de humor:

E o alce e a girafa beberam, beberam, beberam, beberam e finalmente, a girafa disse:

— Não aguento mais.

E o alce disse:

— Eu também não aguento mais.

Eles continuaram a correr, só que não conseguiam correr rápido. De tanta água que tinham bebido.

E o elefante viu isso e desatou a rir!

Parava e ria! Parava e ria!

E o cachorro foi devorado pelas pulgas ao longo do caminho. Sentou-se e começou a se coçar!

Sentava e coçava! Sentava e coçava! (p. 71)

Essa subversão também ocorre por meio da paródia de um conto dos irmãos Grimm chamado "A lebre e o ouriço". Na história clássica, um ouriço e sua mulher conseguem enganar a lebre e fingem ser o animal mais veloz. No conto de Kharms, o pequeno animal pretende dar à colega uma lição de valentia, mas mostra-se tão medroso quando sua aprendiz:

— Espere, - gritou a lebre — você queria me ensinar a ficar corajosa.

E com estas palavras, a lebre amoitou-se no arbusto, de novo.

- Para ficar corajoso - disse o ouriço, colocando o focinho para fora, mas, de repente, viu que a lebre tinha sumido de novo.

- Ai - ai - ai! De novo... atchim! Sumiu de novo. - gritou o ouriço e pôs-se a correr.

O ouriço corria, parava, espirrava e corria mais. Espirrava e corria, de novo. 
A lebre saiu da moita e pôs-se a rir. (p. 75)

Outro gênero parodiado por Kharms, são os romances de aventuras. Em “A pena da águia dourada", de 1928, numa aula de alemão, aparentemente entediante e sem significado para as crianças, os "índios" Gallapum Pulo da Fera e Tchin-Gak-Khuk montam um plano para defender dos inimigos o "Desfiladeiro do Castor". O ambiente da escola é transformado pela brincadeira dos alunos em num mapa americano:

Eu dei a cada classe nomes americanos. Por exemplo, no mapa o Alasca encontrase acima, no canto direito, já na planta de nossa escola lá fica a classe D. Por isso, eu chamei a classe D de Alasca. As classes A e B de nossa planta ficam embaixo. $\mathrm{Na}$ América, aqui é bem onde fica o México. Nossa classe é o Texas e a classe dos caras-pálidas é o Canadá (p. 54).

Todos os elementos da realidade são renomeados pela imaginação infantil de acordo com o ambiente de guerra entre índios e caras-pálidas apresentado nos romances de faroeste:

(...) logo após terminar a aula de alemão, todos os índios deveriam se reunir no corredor escuro atrás dos armários de equipamentos de física (...) Esse lugar era chamado de "Desfiladeiro do Castor"(...) Na segunda carteira estava sentado o chefe Comanche Gallapun Pulo da Fera ou, como o chamávamos na escola, Semion Karpiênko, pronto para pular de pé a qualquer instante. Ao lado de Gallapun estava sentado o índio Tchin-Gak-Khuk, grande chefe dos Araucanos. (p. 52) (grifos nossos)

Eram chamadas de "telégrafo" duas bobinas pregadas sob as carteiras, uma sob a carteira de Gallapun e a outra sob a carteira de Nikítin. Entre as bobinas havia uma linha esticada com uma caixinha de fósforos ligada a ela. (p. 53) (grifos nossos)

O Curumilla, ou como o chamavam os professores caras-pálidas, Nikítin leu a ordem de Gallapun e enviou a resposta: "Curumilla, Ouro Preto, executa pedido de Gallapun, Pulo da Fera”. (p. 54) (grifos nossos)

Reconhecemos na terminologia utilizada pelo escritor o diálogo com a obra de Gustave Aimard ${ }^{228}$, romancista francês, autor de inúmeras histórias de aventuras, nas

\footnotetext{
${ }^{228}$ Pseudônimo de Olivier Gloux (1818 - 1883) romancista francês que esteve, inclusive, no Brasil durante o Segundo Reinado.
} 
quais índios americanos figuram como personagens principais. Através da paródia, Kharms permite que a criança soviética use sua imaginação para transformar a realidade circundante. Além disso, o escritor propõe a atualização do conto infantil a partir da utilização de temas encontrados nas aventuras dos exóticos romances indigenistas.

O desenrolar das ações transcorre minutos antes do término da aula de alemão, onde os índios planejam sua estratégia para ficar com o lugar. Tudo concorre para e o leitor tenha a sensação de que presenciará uma cena de briga entre as crianças, porém o desfecho da história é conquistado através de uma solução diplomática:

Os índios, sem pressa, anotaram a lição de casa e saíram da classe. Os caraspálidas já os aguardavam no corredor.

— Ei vocês! — gritaram os caras pálidas — É hora de lutar, entrem no Desfiladeiro que nós vamos arrancá-los de lá!

Gallapun saiu à frente e fez uma profunda reverência.

- Caras-pálidas! - disse ele - O Desfiladeiro do Castor é grande o suficiente para alojar dentro dele vocês e nós também. Será que vale a pena brigar por causa dele, quando ele pode ser de quem sair correndo da classe primeiro? Eu proponho outra coisa. Vamos todos para o Desfiladeiro e discutiremos minha proposta.

E no Desfiladeiro se ajuntou tanta gente quanto podia caber lá dentro. (p.

Através das paródias, observamos que Kharms sobrepõe, em sua obra infantil, elementos da realidade e da fantasia. De modo que, essa característica possibilita tanto o intercâmbio de eventos mágicos e reais num mesmo conto, quanto a leitura múltipla de uma mesma realidade.

Em “Como Kolka Pânkin voou para o Brasil e Pietka Erchov não acreditou em nada", a natureza exótica da paisagem brasileira é contrastada com a da Rússia-soviética através da visão infantil, de modo a revelar, numa mesma cena, a sobreposição de duas possíveis realidades: a imaginária e a real. Visto que, Kolka vê o Brasil onde Pietka percebe a mesmice:

— Você não viu o bisão! - perguntou Kolka.

— Onde? - perguntou Pietka.

— Lá, ora! Ele avançou pra cima da gente. — disse Kolka.

— Mas não era uma vaca? — perguntou Pietka. 
— Que vaca que nada. No Brasil não há vacas. — disse Kolka. Pietka. (...)

— Mas será que os bisões andam com sininhos no pescoço? — perguntou chegássemos ao Brasil. Se aqui é o Brasil, então aqui deve haver papagaios. disse Pietka. Pánkin.

— Papagaio não dá pra ver, mas os beija-flores estão ali. — disse Kolka

—É aquilo lá no pinheiro? - perguntou Pietka.

— Isso não é pinheiro, é palmeira. — ofendeu-se Kolka.

- Mas, nos desenhos, as palmeiras são diferentes. — disse Pietka.

- Nos desenhos são diferentes, no Brasil são assim. - ficou bravo Kolka - Olha só que beija-flores!

— Parecem com nossos pardais. — disse Pietka. (p. 48)

Verificamos, que o modo diferente como ambos os garotos interpretam a realidade apresentada diante de seus olhos permite-lhes enxergar nesse espaço natural lugares absolutamente diferentes. Os elementos que compõem o quadro paisagístico: árvores, pássaros e animais ganham dupla significação de acordo com o desejo ou capacidade imaginária do sujeito observador. Ao passo que as demarcações geográficas são corrompidas pelo imaginário, tendo em vista que as crianças iniciam sua viagem de avião, mas retornam de automóvel. Lembremos que, à época, o governo daquela nação impunha rígidas restrições para emigração, fato que tornava quase impossível a saída de um cidadão para o estrangeiro.

A idealização estereotipada do país tropical com seus beija-flores, papagaios e "bisões”, em todo seu exotismo, representa uma espécie de paraíso inatingível aos pequenos soviéticos. De modo que, a literatura sugere aos leitores uma válvula de escape que não encontravam para as vicissitudes da vida real.

\subsection{O fantástico-maravilhoso}

A obra infantil de Kharms dá mostras de como os elementos do fantásticomaravilhoso continuavam vivos e atuantes, no subsolo da literatura oficial soviética. Nos contos onde atuam animais antropomorfizados, dotados de características humanas, 
percebemos de forma mais explícita a atuação desse mundo que perde os vínculos com a realidade concreta e cujos "elementos sobrenaturais não provocam qualquer reação particular, nem nas personagens, nem no leitor implícito" (Todorov, 2003, p. 60) Tendo em vista que, a ação de tais seres não carece de explicação lógica:

Era uma vez duas amigas: a lebre Rabinho Cinza e a raposa Rabinho Ruivo.

Cada qual construiu para si uma casinha e começaram a visitar-se uma à outra.

Era só a raposa não vir à casa da lebre, que a lebre ia correndo até a da raposa e gritava:

"Rabinho Ruivo! O que há com você?" (p. 151)

Por meio desse tipo de paródia, Kharms propiciava leituras atualizadas das tradicionais fábulas, aproveitando-se da identificação da criança com essas personagens alegóricas: "se animais falam, nenhuma dúvida nos assalta o espírito (...)” (Todorov, 2003, p. 38): "Não pode ser. — disse o ouriço — Eu não vi você. Eu até gritei, mas você...”" (p. 74)

Entretanto, a atuação do maravilhoso, na obra kharmisiana, também extrapolava esse mundo indiscutível de magia, para agir em situações supostamente pertencentes à realidade. Desse modo, eventos estranhos, que não possuem explicação lógica, surgem no enredo através de situações absurdas: “Assim somos transportados ao âmago do fantástico. Num mundo que é exatamente o nosso, aquele que conhecemos, sem diabos, sílfides nem vampiros, produz-se um acontecimento que não pode ser explicado pelas leis deste mesmo mundo familiar" (Todorov, 2003, p. 30).

No conto "Uma vez perguntaram-me como funciona o automóvel”, o narradorprotagonista é surpreendido por um acontecimento fantástico, em meio às suas atividades cotidianas:

Mas no primeiro dia de março, lembro-me como se fosse hoje, peguei a bacia. E a minha bacia, é preciso dizer, era pequena, de ferro e para despejar sua água, bastava virá-la.

Pois bem, tomei banho na bacia e entornei-a para despejar sua água. Mas, de repente, dela caiu um homem. (p. 93) 
A aparição de um homem dentro de uma bacia surpreende tanto a personagem, quanto o leitor e permanece sem explicação ao longo da leitura. Duas outras informações contribuem com o absurdo da situação: o fato do homem ser um "linotipista" decidido a conduzir um interrogatório sobre o funcionamento de um automóvel: "Sou o linotipista — disse o homem. — Não se pode jogar fora o linotipista com a água do banho. Mas tudo isso não tem a ver com nosso assunto. Eu desejo saber como funciona o automóvel" (p. 94)

Ocorre que, no decorrer da história, mesmo tomado pela surpresa, o protagonista parece tomar o fenômeno extraordinário como algo aceitável, pois ele passa a responder às perguntas do interrogatório, após ter sido ameaçado:

Com estas palavras o linotipista agarrou-me pelo colarinho.

- Veja bem, - disse eu - um automóvel funciona de forma a se movimentar com ajuda do motor.

— Sei — disse o linotipista. - E o que mais?

- As principais partes do motor, em essência, são: o carburador, os cilindros, o magneto e o virabrequin.

— Não entendi nada - disse o linotipista.

— E que culpa tenho eu? — disse eu. (p. 94)

Dessa maneira, o ingresso incomum do linotipista no enredo é mascarado pela descrição técnica do motor do carro.

No conto "Certa vez comprei um lápis", outro evento nonsense invade o cotidiano das personagens por meio de uma barata que, ao longo da história, transforma-se num outro animal maior e assustador:

Mas, de repente, a barata deu um estalo e pulou para o teto (...) Daí, por algum motivo, virei a cabeça e, naquele mesmo segundo, pulei da cadeira e corri para o meio da sala.

Na parede, perto daquele lugar onde eu estivera, havia mais um inseto bem estranho, só que era maior, do tamanho de um fósforo e meio. Ele olhava para mim com dois olhinhos negros e mexia a boquinha parecida com uma flor (...)

O inseto olhava para mim e respirava como um pardal (p. 77) 
A dúvida a respeito da natureza desse incidente persiste e confirma a ocorrência do fantástico. “O fantástico implica portanto não apenas a existência de um acontecimento estranho, que provoca hesitação no leitor e no herói” (Todorov, 2003, p. 38):

— Mas diga, Aleksandra Mikháilovna, o que era? — perguntou Sierguiéi Ivánovitch do apartamento 53.

— Não sei, não sei, não sei! — gritou titia. Só que ele bateu tanto na porta que o chão e o teto estremeceram. (p. 78)

Sem encontrar explicação ou ajuda externa, Bória e tia Sacha são expulsos do apartamento pela presença do animal misterioso.

Nos contos "Era verão. O sol brilhava" e "Volódia estava sentado à mesa desenhando", os protagonistas deixam seu cotidiano e entram no universo imaginário. Platon recebe a visita de um gato e uma garça que o transportam pelos ares, à sua revelia:

- Sim, então vamos voar! - disse o gato montando nas costas da garça. - Voar para onde? - perguntou Platon. Mas a garça já o agarrava com o bico pelos colarinhos e começava a levantar voo.

- Solte-me! — gritou Platon. (p. 91)

Enquanto, Volódia vai parar dentro de seu desenho e passa a interagir com sua própria criação: "Volódia saiu correndo atrás de Karl Ivánovitch” (p.132).

Nesses dois casos, a porta de entrada do fantástico parece vislumbrar uma possível explicação lógica: o ingresso dos garotos no mundo dos sonhos. Platon embalado pela rede: "A rede balançava e fazia um rangido agradável, ao redor voavam borboletas e zumbiam abelhas, dava para escutar o modo como o Primus ruidava dentro de casa e Platon continuou deitado na rede a se balançar" (p. 91) e Volódia tomado pelo cansaço: "Pensou, pensou e deu um bocejo. Depois bocejou outra vez e decidiu desenhar uma lebre embaixo do arbusto" (p. 131)

Contudo, apesar do sono ser uma possibilidade interpretação desses fatos, ainda há hesitação por parte do leitor e das personagens sobre a procedência fantasiosa ou "realista”, característica que reforça o procedimento fantástico na narrativa. 
Para Todorov (2003, p. 169), a literatura fantástica, nos séculos XVIII e XIV, abordava temas proibidos socialmente como o incesto, homossexualismo e sexualidade. Por isso, "os temas da literatura fantástica se tornaram, literalmente, os mesmos das investigações psicológicas nos últimos cinquenta anos.”

Tendo em mente essa questão dos temas subliminares ao fantástico, na literatura romântica, podemos pensar que os eventos extraordinários presentes na literatura infantil de Kharms também abordavam "tabus" próprios da sociedade soviética e revelavam situações vividas ou presenciadas pelos cidadãos, mas que não podiam ser abordadas diretamente.

“O autoritarismo desmedido, a impossibilidade de responder negativamente às determinações do Partido, sob pena de uma perseguição tal que, seguramente, resultaria em prisão e morte (com sorte, sem tortura), a invasão da instância do privado de maneira abrupta, remetem a uma situação muito próxima do que se vivia na época de Stálin” (Lima, 2001, p. 70). Desse modo, os eventos fantásticos acima abordados mostram, nada mais do que cenas de perseguição, invasão de domicílio, interrogatórios policiais e prisão.

\subsection{Violência}

A atmosfera de violência presente na sociedade soviética acaba sendo captada pela obra de Kharms, de modo que, ao entrarmos em contato com as histórias dessa coletânea, somos atraídos também para as marcas de violência mescladas à realidade nelas retratada. "The epoch of the birth of the Soviet Nation had arrived. The air was saturated with violence. Art attempted to shape this process discursively and to package it in books (...)" (DOBRENKO, 2010, p. 44)

Não estamos a afirmar que a violência nunca esteve presente na LIJ, muito pelo contrário, ela sempre foi marca costumeira nos contos tradicionais do gênero, servindo 
contraditoriamente como recurso educativo, mostrava às crianças as consequências da desobediência e os perigos do mundo. Por isso, nos contos maravilhosos, abundam cenas de violação sexual, lutas sangrentas, humilhação, exploração do trabalho, canibalismo etc. Ocorre que, encerrados nesse universo mágico, todos os atos violentos são entendidos simbolicamente, seja como meio necessário para que heróis cumpram sua missão, seja como forma de se abordar tabus.

Kharms satiriza essa característica numa pequena paródia em que a reiteração crescente da violência conduz ao absurdo e à jocosidade:

Então, a rainha ficou brava e acertou o rei com um prato. E o rei acertou a rainha com a tigela. A rainha bateu no rei com a cadeira. $\mathrm{O}$ rei deu um pulo e acertou a rainha com a mesa. A rainha derrubou o bufete em cima do rei. Mas o rei saiu debaixo do bufete e atirou a coroa na rainha. Daí, a rainha puxou o rei pelos cabelos e jogou-o pela janela. Mas o rei subiu de volta para o quarto por outra janela, agarrou a rainha e enfiou-a dentro do fogão a lenha. Mas a rainha saiu no telhado pela chaminé, desceu ao jardim pelo para-raios e tornou a voltar para o quarto pela janela. Nessa hora, o rei aquecia o fogão a lenha para queimar a rainha. (p. 122) (grifos nossos)

Verificamos que os golpes, os arremessos de objetos e a tentativa de assassinato deixam de ser recursos simbólicos e tornam-se motivos através dos quais o autor consegue efeitos de humor, enfatizados através da repetição. Contudo, o uso exagerado e repetitivo desse procedimento acaba por desnudá-lo, ao passo que expõe sua estrutura e modo de ação, daí provindo seu efeito cômico.

Assim como acontece com uma palavra que, repetida incessantemente em voz alta, desgruda-se de seu conceito e adquire concretude. A repetição, procedimento largamente utilizado por Kharms, mostra que a reprodução contínua de uma atitude violenta tende a torná-la banal e aceitável, até mesmo ridícula.

No conjunto da obra de Kharms, a violência emerge, por vezes gratuitamente, do próprio cotidiano e torna-se seu elemento componente: "Piotr Sapogov aproveitou-se da escuridão e deu um soco nas costas de Altofalante" (p. 25); “o homem montado no asno 
(...) levantou uma espécie de tubo com uma ponta estreita e outra larga feito uma boca de corneta. Apoiou na boca a ponta estreita, daí pôs-se a gritar de lá bem na cara da velhinha, tão alto que dava para ouvir a sete léguas” (p. 64). A literatura parece refletir os movimentos de uma sociedade que substituía a fala pelo grito panfletário, os salamaleques "burgueses" pela planificação das formas de tratamento, a conversa franca pelo murmúrio amedrontado, a liberdade de expressão pelo controle do Estado. Ou seja, uma sociedade onde a privação dos direitos individuais invadia todas as suas esferas.

No conto "Como Kolka Pánkin voou para o Brasil e Pietka Erchov não acreditou em nada", ocorre uma briga entre Kolka e os "aborígenes", devido à falha na comunicação entre as partes. O garoto, que pensava estar no Brasil, entra em conflito mesmo sem tal pretensão, é espancado por um bando crianças "sujas e louras" que "depois de bater o quanto puderam em Kolka, (...) pegaram pó, jogaram no ar e saíram correndo. Kolka ficou lá, desgrenhado e todo amassado" (p. 46)

Nessa história, o episódio da surra é apenas uma das tantas aventuras encontradas pelos meninos, já que a narrativa está dividida em onze partes, cada qual contendo uma peripécia. Todas as cenas são permeadas pelo mesmo tipo de humor que expõe as crianças à violência e ao desamparo.

A violência cotidiana apresenta-se, em geral, camuflada pela comicidade com total despreocupação acerca do politicamente correto. Tal característica aproxima o riso kharmisiano do humor negro de Wilhelm Busch $^{229}$. Na obra de ambos, muitas vezes, as crianças figuram entre as grandes vítimas truculência física; Kharms inclui nesse grupo também as velhas.

\footnotetext{
${ }^{229}$ No Brasil, uma das obras mais importantes de Busch, chamada "Max e Moritz", foi traduzida por Olavo Bilac sob o título de "Juca e Chico". Considerada uma das precursoras das histórias em quadrinhos, nela dois garotos azucrinam a vida dos adultos até serem triturados num moinho e servidos como comida de patos.
} 
Desse modo, a reiteração da violência, vivenciada pela sociedade nos anos mais duros do período stalinista, encontra eco na literatura infantil onde não precisa ser tratada com a devida seriedade, podendo aparecer disfarçada com humor e suscitar o riso do leitor, mesmo diante de situações absurdas.

\subsection{A linguagem transmental (zaum)}

"Entrão vramos vroar! - disse a garça."

Um dos elementos de experimentação literária bastante explorados no conjunto da obra de Kharms diz respeito ao emprego do zaum que, uma vez extirpado do Realismo Socialista, encontra campo fértil de atuação na LIJ, onde será revivido através de brincadeiras sonoras e trocadilhos típicos do palavreado pueril.

Valiéri Sajin (2011, p. 9), no prefácio à coletânea das obras de Kharms discute, justamente, a assimilação dos métodos experimentais de criação, preconizados pelos oberiúty, por sua literatura infantil e lembra-nos de que a proximidade entre as duas produções era tamanha que o escritor, por vezes, recitava poemas infantis de sua autoria nas apresentações do movimento. Da mesma maneira que seu poema "Ivan Ivánitch, o samovar” (1927), por exemplo, era apreciado por leitores de todas as idades.

Nosso grupo começou a trabalhar na esfera da literatura infantil em 1927. À qual trouxemos elementos de nossa arte para adultos, isto é o "zaum" que, no protocolo anterior, eu chamei de contrarrevolucionário. No mais, o "zaum" aparece nas minhas seguintes produções: "Iván Ivánitch, o samovar", "Iván Toporíchkin", "Como uma velhinha comprava tinta", "Em primeiro e em segundo lugar", entre outras. (...) Em particular, desse ponto de vista, posso ainda mostrar que o poema chamado "O mentiroso", publicado na revista Tchij, contém elementos do absurdo. (Protocolo de interrogatório. In: Kharms, D., 1994, p. 291 -292)

O supracitado excerto, retirado do questionário interrogatório respondido pelo autor por ocasião de sua prisão, demonstra que, a despeito do gênero para o qual escrevia, o foco do trabalho de Kharms estava centrado no projeto artístico de seu grupo. Ou seja, mesmo ao escrever para crianças o escritor fazia uso de elementos pensados 
anteriormente para o trabalho de vanguarda, donde ele afirmou ter trazido procedimentos para a literatura infantil. São citados mais especificamente o zaum e o absurdo.

O surgimento dessa linguagem nonsense deu-se na esfera de pesquisas cubofuturistas sobre novas formas poética. O ímpeto dos artistas dessa vanguarda era o de romper com a estética da poesia simbolista, considerada como decadentista e antiquada. Desse modo, motivados pelo desejo de recriar na poesia a "textura concreta e rugosa" das pinturas, os poetas se empenham em exercícios de análise e decomposição de palavras, donde surgem expressões inéditas. (RIPELLINO, A. M., 1971, p. 35 - 36) 230 $^{23}$

$\mathrm{O}$ verso, que com os simbolistas havia sido um bordado de lantejoulas cintilantes, um estremecer sem contornos, libertou-se de sua inércia melódica e, enriquecendo-se de elementos mímicos, de rigor acústico, fez-se nodoso, desigual, como uma superfície remendada. (RIPELLINO, A. M., 1971, p. 35)

O produto dessas experimentações aparecia em poemas absolutamente indecifráveis, numa língua avessa à lógica e à comunicação. Como, por exemplo, no seguinte poema de Aleksiei Krutchónikh, de 1912, cuja fixação no estrato sonoro despreza qualquer compreensão semântica:

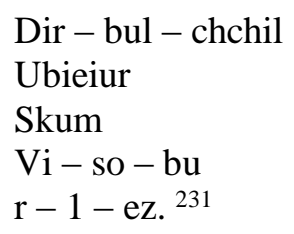

Entretanto, ao lado do alto grau de abstração alcançado por alguns poemas zaum, podemos considerar que certos vocábulos criados no âmbito desses experimentos ganham significação ao serem contextualizados e analisados no interior dos poemas. É o que

\footnotetext{
${ }^{230}$ Cada poeta possuía uma técnica privilegiada para a criação da língua transmental. Krutchónikh dava preferência "às dissonâncias bruscas, aos monossílabos guturais, às locuções contraídas e crepitantes". Maiakóvski "às misturadas absurdas de sons" e Khlébnikov afixava "novos sufixos às velhas raízes" numa espécie de "escrita aglutinante". (RIPELLINO, A. M., 1971, p. 36 - 37)

${ }^{231}$ Transliteração do poema zaum de Krutchónikh. cf. RIPELLINO, A. M., 1971, p. 36)
} 
acontece, por exemplo, em "Encantação pelo riso", de Khébnikov, cujas palavras inventadas formam uma espécie de mantra encantarório:

Ride, ridentes!

Derride, derridentes!

Risonhai aos risos, rimente risandai!

Derride sorrimente!

Risos sobrerrisos - risadas de sorrideiros risores! (...) ${ }^{232}$ (grifos nossos)

Verificamos que, os vocábulos destacados, formados pela derivação e aglutinação de morfemas, não possuem sentido quando considerados individualmente. Mas encontram significado pleno de expressão no interior poema. Nesse sentido, tais criações zaum aproximam-se das brincadeiras de criança nas quais são inventadas palavras que só funcionam enquanto dura o divertimento, pois quando dali retiradas perdem sua razão de ser.

Daí podemos dizer que a criança, em sua atitude brincante, a seu modo já executa através de cantigas de roda, quadrinhas, línguas de mentirinha etc., uma espécie primitiva de zaum. A LIJ também ecoa essa ludicidade linguística tão atrativa aos pequenos leitores e, por conta dessa característica, Kharms tem a oportunidade de empregar pinceladas de sua herança zaúmniki tanto nas poesias, quanto nos contos infantis.

Entretanto, lembramos que, àquela altura (após 1928), essas práticas experimentais eram oficialmente proibidas na arte soviética. Por isso, o zaum kharmisiano apresenta-se camuflado dentro dos contos; revestido pelas interjeições, onomatopeias, falhas de comunicação, línguas inventadas etc. Assim, verificamos manifestações contextualizadas desse linguajar disparatado, perfeitamente confundidas com os ruídos do enredo.

O poeta oberiúty aplica-se, então, em realizar jogos fonéticos nos quais o som exerce papel central e substitui o sentido semântico. (TUMANOV, L., 1993, p. 5). Essa

\footnotetext{
232 "Encantação pelo riso”, de V. Khlébnikov com tradução de Haroldo de Campos e Boris Schnaiderman.
} 
é uma das formas de entrada da língua transmental na LIJ e acontece, por exemplo, no poema "O velhinho alegre" 233 . Nele a risada "extraordinária" da personagem realiza-se da seguinte forma:

$$
\begin{aligned}
& \text { Ha - ha - ha } \\
& \text { Da ha - ha - ha } \\
& \text { Hi - hi - hi } \\
& \text { Da bukh - bukh - bukh! } \\
& \text { Bu - bu - bu } \\
& \text { Da be - be - be } \\
& \text { Din - din - din } \\
& \text { Da triukh - triukh - triukh! }
\end{aligned}
$$

Percebemos que Kharms mescla onomatopeias típicas do riso ${ }^{234}$ : "ha", "he”, "hi”" à outras completamente estranhas: "bukh", "din”, "triukh” que beiram ao nonsense, mas, ao mesmo tempo, enfatizam a gargalhada bonachona com toques transmentais. Ou seja, onomatopeias corriqueiras dão lugar à novas, que inserem o nonsense ao texto. "Play with language in Charms, which often results in baby sounds or nonsense syllables coming out of characters' mouths, is very common, and - in spite of the Oberiu manifesto - echoes similar Futurist experimentation (...)" (TUMANOV, L., 1993, p. 5)

Nos contos deste trabalho, primeiramente, distinguimos a exploração da sonoridade puramente onomatopaica para expressar sons dos objetos e transportes: "t-rr-r-r! - pôs-se a tocar o sinal” (p.); "fon, fon, fon! - grita o carro (...) dlen, dlen! Dlen, dlen! - passa o bonde (...) prum, prum, prum! - estronda a motocicleta” (p. 65). Vozes de animais: “é um pássaro. Ele chilreia bem assim: 'tirli- tirli, tiu - tiu - tiu”” (p. 23); “a rã responde: Croac, croac!” (p. 68); “Chegou a patinha Aninha. Olhou para o quadro de uma lado e disse: quá, quá, quá!” (p. 127). Falas e emoções das personagens: “ha, ha, ha! - gargalhou o gordo" (p. 69); “i-i-i-i-! - guinchou tia Sacha” (p. 77); "pfft. - cuspi eu” (p. 96) (grifos nossos), entre inúmeros outros casos espalhados pela obra. Nesses

\footnotetext{
233 “Весёлый старичок” (1940). Aqui apenas transliteramos o texto russo.

${ }^{234}$ As onomatopeias que exprimem riso coincidem em português e em russo.
} 
casos, não estamos inseridos no âmbito do zaum ainda, mas é através dessa exploração fonética que, muitas vezes, o escritor encontra caminhos para a experimentação.

Onomatopeias estranhas, engraçadas e sem sentido surgem instituindo no texto elementos absurdos, que colaboram para afirmar o caráter moderno desses jogos sonoros. Vejamos o conto "Kolpakov, o fanfarrão", cuja personagem do valentão mergulha com escafandro, num rio, para mostrar sua valentia. Após ser submerso, começa a afogar-se e diz aos mergulhadores, à margem, palavras sem sentido, mas capazes de revelar seu desespero:

Fiódor Fiódorovitch Kolpakov entrou na água e os mergulhadores the gritaram lá de cima pelo telefone:

— E, aí, Fiódor Fiódorovitch? Dá muito medo?

E Fiódor Fiódorovitch lhes respondeu lá de baixo:

— Niav... niav... niav... (p. 112) (grifos nossos)

Ao invés de usar uma onomatopeia convencional para representar a voz de uma pessoa em situação de afogamento, como "glup"235; Kharms cria o som "niav" e, com isso, introduz no enredo um elemento inusitado, ao mesmo tempo cômico.

O mesmo procedimento é verificado em "O professor Trúbotchkin" quando o telefone da redação de Tchij toca, mas saem do fone barulhos incompreensíveis: "Bu-bubu... budu... bu-bu... mais... ma... bali balu... tu-bu-bu! - saía do fone” (p. 103). Nesse exemplo, algumas sílabas aleatórias insinuam palavras reais, mas nenhuma mensagem compreensível pode ser extraída dos ruídos. De maneira que o extrato sonoro, novamente, suplanta o lógico. No mesmo conto, Kharms elabora mais uma forma de expressar o riso: “Fui eu! Fui eu!- khra!-khra!-khra! Que sequestrei o Professor Trrrrúbotchkin” (p. 104) (grifos nossos). Assim, observamos que a gargalhada do Gigante Bobov torna-se amedrontadora ao ser incrementada pelas pelo fonema [ $\mathrm{r}$, contribuindo para caracterizar com mais veracidade a personalidade estrondosa desse antagonista.

${ }^{235}$ Em russo, "bul" é o som usado para representar afogamento. 
O cocoricar do galo Erofei, em "Sobre o cachorro Bububu" é expresso, primeiro, em sua forma comum “cu-cu-ru-cu”, em seguida permutado para "ca-cu-re-cu” (p. 127), numa estratégia para ampliar as possibilidades lúdicas com elementos concretos do texto. Já que a criança pode sempre ler buscando imitar o cantar da personagem, dando continuidade à brincadeira.

Exemplares desse zaum onomatopaico podem ser percebidos no transcorrer de todas as histórias desse trabalho. "This agglomeration of morphemes or phonemes, which in many cases are not even Russian, serves to deautomatize our sense of the Russian language, to push our normal phonic reflexes out of their familiar pathways." (TUMANOV, L., 1993, p. 7)

Outra forma, experimentada pelo autor, de brincar o absurdo da sonoridade destituída da lógica, encontra-se nas falas, diálogos e línguas das personagens.

A atenção à sonoridade é condição necessária aos pequenos, como ressalta Ligia Cademartori (2010, p. 37): “A poesia infantil brinca com os sons e, ao fazê-lo, favorece a percepção da materialidade da língua e de seu potencial lúdico. A presença do ritmo, que alterna, em intervalos regulares, ou não, tempos e acentos, em movimento cadenciado, é também muito importante para a musicalidade do poema".

A linguagem da macaca Dona Maria Timoféievna, em "Sobre o cachorro Bububu", por seu turno, é composta por sílabas completamente sem nexo, mas leva a criança leitora a imaginar o chiado do animal. Do mesmo modo que as aliterações de $[b]$ e $[l]$ parecem imitar, em tom humorístico, o tipo de produção encontrada em poemas cubofuturistas:

- Bal - bal - bal - bal.

Bol - bol - bol - bol.

- Ei! gritaram para a macaca. - Fale direito!

E ela de novo:

- Lok! vok! mok! roc!

Luk! lak! lik! lek! (p.) 
Kharms inclui, num dos contos, um pequeno poema engendrado pelo garoto Fédia Kótchkin. Este garante escrever "versos muito bons" numa velocidade tão alta que sua mão até "embaçava e sumia" durante o processo. Ao terminar a obra, a personagem apresenta uma quadrinha zaum, composta por sílabas sem significado; apenas assonâncias e aliterações. A invenção de palavras era um procedimento do zaum, muito utilizado por Krutchónikh que "inventa palavras desleixadamente, expressões nunca ouvidas que se diriam tiradas do léxico de uma tribo selvagem”. (RIPELLINO, A. M., 1971, p. 36)

Jik, jik, jik

Foc, foc, foc,

Ric, ric, ric,

Chuk, chuk, chuk (p.)

Segundo a personagem-autora, os versos estariam em "filtolskiano", como aparece num diálogo explicativo, marcado pelo humor extraído dos substantivos vozeados e sem sentido. O leitor verifica que tanto o idioma referido, quanto as localidades citadas não existem, de fato, mas tratam-se de invenção de Daniil Kharms:

— O que é isso? - gritou o redator — Não entendi nada!

— Está em fistolskiano. - disse o Professor Trúbotchkin.

— Isso é uma língua? - perguntou o redator.

—É sim, os fistolsnianos falam nessa língua. — disse o Professor Trúbotchkin.

— E onde vivem os fistolsnianos? - perguntou o redator.

— Em Fistólia. - disse o Professor.

- E onde é que fica Fistólia. - perguntou o redator.

- Fistólia fica em Kompótia. - disse o Professor.

- E onde fica Kompótia? - perguntou o redator.

— Em Tchutchêtchia. - disse o Professor.

- E a Tchutchêtchia? -

- Em Bambâmbia.

- E a Bambâmbia?

—Em Tilipampâmpia. (p. 101) (grifos nossos)

A conversa, então, acaba constituindo-se em puro jogo linguístico, de modo que uma nova palavra irreal é acrescentada a cada pergunta, mas não se explica nada com elas. Percebemos que os elementos lúdicos e estéticos, em sua relação com o zaum, estão associados, na LIJ desse autor. 
Outra língua nonsense presente na prosa de Kharms é a “indígena”, percebida nos contos "A pena da águia dourada" e "Como Kolka Pánkin voou para o Brasil e Pietka Erchov não acreditou em nada". No primeiro, as personagens apresentam uma espécie de glossário com algumas palavras do "idioma" e seus significados:

Ele fingia que copiava verbos alemães da lousa, mas o que fazia mesmo era escrever palavras indígenas para serem usadas em tempos de guerra.

Tchin-Gak-Khuk escreveu:

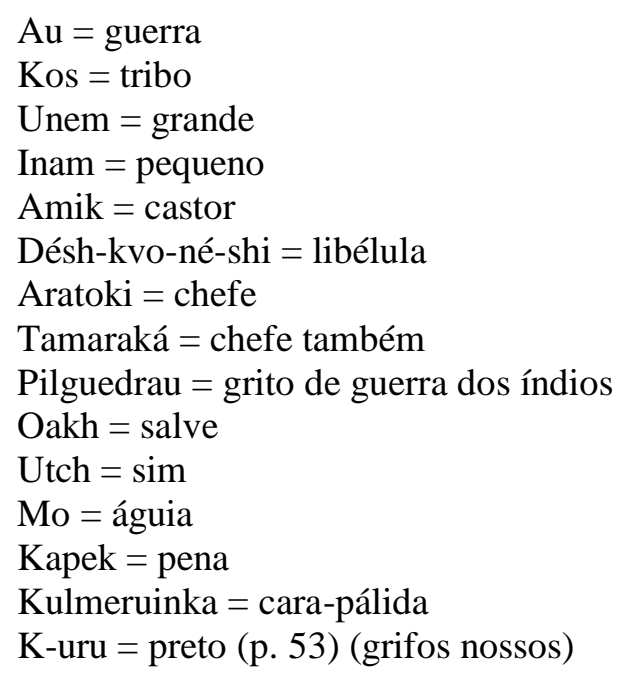

No segundo, as personagens testam a eficácia do indígena na prática, dando origem a uma conversa absurda, que não conduz a bom termo: calados.

— Oakh! — disse-lhes em indígena. Os aborígenes ficaram boquiabertos e

- Hapakuk! — disse-lhes Kolka, em indígena.

- O que é isso que você está falando? - perguntou Pietka.

— Estou falando com eles em indígena. — disse Kolka.

— E desde quando você sabe a língua indígena? - perguntou Pietka.

— É que lá em casa eu tinha um livrinho e aprendi por ele. — disse Kolka.

- Ah, conta outra! - disse Pietka.

- Pare - disse Kolka. - Inam kos! - disse ele aos aborígenes em indígena.

De repente, os aborígenes puseram-se a rir.

— Kerek ery iale. - disseram os aborígenes.

- Ara toki. - disse Kolka.

- Mita? - disseram os aborígenes.

— Deixa pra lá, vamos indo. - disse Pietka.

- Pilguedrau! - gritou Kolka.

- Perkilia! - gritaram os aborígenes.

— Kulmeguinki! — gritou Kolka.

- Perkilia, perkilia! - gritaram os aborígenes.

- Corre! - gritou Pietka. - Eles querem briga.

Mas já era tarde. Os aborígenes caíram em cima de Kolka e começaram a bater nele.

— Socorro! — gritou Kolka. 
- Perkilia! - gritaram os aborígenes.

— Muu-uuu! — mugia uma vaca. (p. 46) ${ }^{236}$ (grifos nossos)

Nessa tentativa de comunicação entre os garotos, o leitor não tem acesso ao significado de todas das palavras, podendo apenas inferir o que se diz pelo tom do texto e ações consequentes, através da imaginação. Para criar esse efeito, Kharms insere palavras listadas em outra história, como vimos, além de introduzir o xingamento em finlandês "perkilia". Entretanto, a mistura dá origem a uma conversa desencontrada e absurda, na qual até mesmo o mugido de uma vaca, ao final, parece fazer parte da bizarra composição.

Nathália Xavier Thomaz (2012, p. 23), em seu estudo sobre Alice no País das Maravilhas e tendo como base o trabalho de Lúcia Bastos (2001), chega a uma definição bastante adequada sobre o nonsense, que pode ser, aqui, empregada ao tipo de brincadeira sonora aplicada por Kharms.

(...) o foco do nonsense não é apenas o não-sentido, mas uma busca por tornar o sentido mais intuitivo e imaginário. É uma desconstrução do paradigma cartesiano por meio de sua negação e com a imposição de uma lógica do avesso, que lembra o pensamento infantil. Apesar de se fundar na ideia da brincadeira com os significados das palavras, com a desobediência do gramatical e do pragmático, o nonsense tem uma forte lógica interna de funcionamento. É essa lógica que permite que o trocadilho seja entendido, e o questionamento seja válido.

Em outra passagem, verificamos que, a dificuldade de comunicação decorrente da discrepância entre o que se fala e o que se compreende, aparece como procedimento para a introdução do nonsense no enredo. Ou seja, é um meio de transformar o diálogo entre Kolka e Pietka num crescente desentendimento:

— Piet-ka! — grita Kolka. — Olhe, que cidade tortinha!

- O que-e-e? - grita Pietka.

- A ci-da-de! — grita Kolka.

—Não estou ouvindo! — grita Pietka.

- O que-e-e? - grita Kolka.

\footnotetext{
${ }^{236}$ Algumas das palavras usadas por Kolka podem ser traduzidas tomando-se como apoio a lista do conto anterior. Assim sabemos que ele disse aos garotos: "salve", "pequena tribo" e "chefe".
} 
— Será que o Bra-sil está perto? — grita Pietka.

— Que Vassi-li? — grita Kolka.

- O chapéu saiu vo-an-do! - grita Pietka.

— Quanto? - grita Kolka.

— On-tém! - grita Pietka.

- América do Norte! - grita Kolka.

— Na-vi-da-ri-di! — grita Pietka.

— Que-e? — grita Kolka. (p. 44)

Para alguns filólogos estudiosos do zaum, parte das raízes dessa língua encontravam-se na "fala das crianças" e nas "gírias das seitas"237. Seguindo nessa esteira, Kharms transforma o tatibitate infantil e a fala sibilante de um velho banguela em fontes dessa linguagem: "Volódia viu uma espingarda: “Dá! Dá!" — grita. Mas “dar” o quê não consegue dizer, porque ele é tão pequeno que nem falar sabe” (p. 82); “Chintcha che vende na locha" (p. 66) (grifos nossos)

Se, por um lado, o balbuciar do pequeno Volódia pode ser interpretado como a manifestação do seu desejo pelos brinquedos, por outro, remete-nos ao Dadaísmo, cujo nome "Dadá" foi sugerido por Ball e Huelsenbeck, em 1916, inspirado no primitivismo das primeiras palavras emitidas pela criança.

Verificamos, então, a estreita relação entre suas obras escritas "para adultos" e "para crianças". A partir disso, chegamos à conclusão de que a literatura infantil kharmisiana também pode ser compreendida como produto do trabalho de vanguarda do escritor ao ilustrar, através de suas características, formas de experimentação artísticas oberiu. Essa fidelidade ao grupo de vanguarda e a sua estética ia de encontro aos propósitos da literatura oficial soviética, como vimos.

Por fim, através de nossa análise, percebemos que o escritor realiza estas experimentações com o linguajar absurdo por meio de recursos e precedentes abertos pelas obras infantis. Nesse sentido, a aproximação ao zaum e a presença do humor ajudam

\footnotetext{
${ }^{237}$ cf. RIPELLINO, A. M., 1971, p. 36.
} 
a afirmar, de certa forma, o caráter paródico assumido por essas obras, tendo em vista o caráter subversivo de tais experimentações, que não ousavam figurar fora de tal gênero.

\section{9 Suprematismo}

O intercâmbio com os pressupostos estilísticos de Malévitch legou à obra de Kharms elementos que podem ser considerados como fruto de sua admiração e diálogo com o Suprematismo. Em seus primórdios, esse movimento artístico já havia surgido da intenção de transportar o abstracionismo da poesia cubofuturista à pintura. Assim, explica Angelo M. Ripellino (1971, p. 38) sobre a proposta de Malévitch:

O cubo-futurismo foi para ele, portanto, apenas um encaminhamento à pesquisa das formas abstratas, a uma pintura fundada na intuição, na supremacia dos sentimentos, e despida de qualquer ligação com o mundo exterior. Ele sonhava devolver uma pureza primitiva (a pureza do nada!) à superfície pictórica. Nasce assim o suprematismo.

Desse modo, a começar pelo quadrado, o mentor dessa vanguarda volta-se para as formas geométricas para criar suas obras: "famílias de triângulos, círculos, trapézios, acumularam-se magneticamente no espaço de seus quadros como adereços e bastões nas mãos de um malabarista” (RIPELLINO, A. M., 1971, p. 39) Os oberiúty, como vimos, defendem abertamente, em seu manifesto, as experiências desse artista.

O compartilhamento de visões de mundo entre os movimentos deixou marcas na obra de Kharms que podem ser verificadas por meio de imagens geometrizadas e pelo apelo aos recursos visuais, presentes em seus contos. Observamos, por exemplo, no conto infantil "Uma vez perguntaram-me como funciona o automóvel”, uma breve discussão entre duas personagens sobre o desenho de figuras geométricas:

- Olhe aqui o desenho do cilindro.

- Isso não é um cilindro, é um quadrado. - disse o linotipista.

- Pfft. - cuspi eu.

- E você pare de cuspir. - observou o linotipista. 
- Que diabos. - disse eu - Isso não é um quadrado, é o desenho do cilindro. Olhe, eu desenho para você. (p. 96) (grifos nossos)

Há outros momentos na obra de Kharms através dos quais observamos a presença e descrição de formatos geométricos. Em "A velha”, diz o narrador após acordar de um sonho delirante: "Vejo à minha frente quadrados perfeitamente desenhados." (In: Lima, 2001, p. 23). Assim como, no conto infantil "Olha, Liénotchka - disse a tia (...)”, a criança ingressa numa brincadeira de destruição e reconstrução, por meio da qual aparece o jogo entre figuras geométricas e dimensões:

- Até logo! Até logo! Até logo, tia! Até logo guardanapo quadrado! - cantava Liénotchka.

Dizendo isso, Liéntochka pôs a tesoura para trabalhar.

- E agora, e agora - pôs-se a cantar Liénotchka - o guardanapo ficou redondo! E agora semicírculo! E agora ficou pequenininho! Havia um guardanapo e agora ficaram muitos guardanapos pequenininhos! (p. 79)

Percebemos, então, que a imagética suscitada, em certas passagens da narrativa conduzem o leitor à visualização de imagens perfeitamente adequadas à estética suprematista.

\section{10 Incidentes}

Entre 1933 e 1939, Kharms dedicou-se à escrita de uma série de "contos" em miniatura aos quais chamou de "Incidentes" (Slútchai) $)^{238}$, "narrativas curtas cujos enredos são construídos a partir de fatos do cotidiano, enfocados realisticamente numa perspectiva do absurdo e marcados pelo paródico, o macabro e o grotesco" (LIMA, S. O., 2001, p. 14).

Tal coletânea, formada por histórias curtíssimas marcadas fortemente pelo absurdo e pelo humor, expõe de forma objetiva alguns procedimentos típicos de Kharms 
como a repetição, o absurdo e a miscelânea de gêneros. A brevidade dos textos e a velocidade com que seus elementos são trabalhados tomam o leitor de surpresa, quebrando com a expectativa deste de tentar enquadrar a narrativa num gênero familiar.

No Incidente a seguir, escrito em 1936, por exemplo, a cômica causa mortis de Orlóv é o estopim de uma sequência marcada por mortes, perdas e desintegrações. Contudo, não há nenhum nexo causal lógico entre os acontecidos:

Certa vez, Orlóv empanturrou-se de ervilha esmagada e morreu. E Krilóv, sabendo disso, também morreu. E Spiridónov morreu por conta própria. E a mulher de Spiridónov caiu do bufê e morreu também. E os filhos de Spiridónov afogaram-se num lago. E a vó de Spiridónov deu de beber e perdeuse na vida. E Mikháilov parou de pentear-se e pegou sarna. E Kruglóv desenhou uma dama com chicote na mão e endoideceu. E Perekhióstrov recebeu, num telegrama, quatrocentos rublos e vangloriou-se tanto que o despediram do emprego.

São boas pessoas, mas não sabem se manter com os pés firmes. (Kharms, D., 2011, p. 334)

Verificamos que Kharms insere Incidentes, como o supracitado, em outros trabalhos, sempre usando como subterfúgio a pena de uma personagem-autora. Em "A velha", o narrador-personagem, espécie de escritor frustrado, escreve a história do milagreiro que, quando retirada do enredo da novela, constitui-se por si num exemplar dos Incidentes kharmisianos:

Este será um conto sobre um milagreiro que vive no nosso tempo e não faz milagres. Ele sabe que é milagreiro e que pode fazer qualquer milagre, mas não o faz. É despejado do apartamento, sabe que basta mexer um dedo para impedir que isso aconteça, mas não o faz; muda-se docilmente do apartamento e vai viver num barracão fora da cidade. Ele pode transformar esse barracão numa bela casa de tijolos, mas não o faz; continua a viver no barracão e, ao final de tudo, morre não tendo feito nenhum milagre em sua vida. (LIMA, S. O., 2001, p. 21)

Dentro dos contos infantis, do mesmo modo, encontramos pequenas histórias independentes, que possuem início, meio e fim próprios, por isso podem ser descoladas do enredo onde estão inseridas. Assim como a personagem do escritor, em "A velha", 
escreve seu conto em miniatura, o escritor gordo, em "Sobre como a velhinha comprava tinta", escreve a história do menino que engole uma rã nos moldes de um Incidente:

O tal menino chegou a casa, o pai perguntou-lhe onde estava e de dentro da barriga a rã responde: Croac, croac! Ou na escola: o professor pergunta ao menino como é "bom dia" em alemão? E a rã responde: Croac, croac! O professor ralha e a rã: Croac, croac! (p. 68)

Outra personagem-autora a povoar os contos de Kharms com historietas cuja tônica está centrada na repetição, no absurdo e na comicidade, é Lienótchka, em "Um conto maravilhoso". Cada vez que ela interrompe o pretenso escritor Vânia, fornece uma amostra desse "gênero", de modo que, tal conto de Kharms acaba sendo constituído a partir do enquadramento de três Incidentes, numa história maior:

Trata-se de como o rei bebia chá com maçãs e, de repente, engasgou-se. A rainha começou a bater nas costas dele, afim de que o pedaço de maçã pulasse para fora da garganta. Mas o rei pensou que a rainha estivesse brigando e acertou a cabeça dela com o copo. Então, a rainha ficou brava e acertou o rei com um prato. E o rei acertou-a com a tigela. A rainha bateu nele com a cadeira. $\mathrm{O}$ rei deu um pulo e acertou a rainha com a mesa. A rainha derrubou o bufete em cima do rei. Mas o rei saiu debaixo do bufete e atirou nela a coroa. Daí a rainha puxou o rei pelos cabelos e jogou-o pela janela. Mas o ele subiu de volta ao quarto por uma outra janela, agarrou a rainha e enfiou-a dentro do fogão a lenha. Mas a rainha saiu lá no telhado pela chaminé, desceu ao jardim pelo para-raios e retornou ao quarto pela janela. Nessa hora, o rei aquecia o fogão a lenha para queimar a rainha. A rainha aproximou-se sorrateiramente e empurrou o rei pelas costas. O rei caiu dentro do fogão e lá foi queimado. (p. 123)

Será possível que você não sabe do bandoleiro? - disse Liénotchka. — Ele estava fugindo da guarda, pulou para cima de um cavalo com tanto ímpeto, que atravessou para o outro lado e caiu no chão. $O$ bandoleiro praguejou e pulou para cima do cavalo de novo, mas errou o cálculo outra vez, cruzou para o outro lado e caiu no chão. Levantou-se, brandiu o punho, foi montar no cavalo de novo, atravessou por cima do bicho e aterrissou no chão. Nisso, o bandoleiro sacou a pistola do cinturão, disparou para o alto e tornou a pular no cavalo, mas com tanta força que, novamente, atravessou por cima dele e estatelou-se no chão. Então o bandoleiro arrancou o gorro da cabeça, pisoteou-o e tornou a pular no cavalo, atravessou por cima dele outra vez, estatelou-se no chão e quebrou uma perna. $\mathrm{O}$ cavalo foi para o lado, o bandoleiro correu mancando até o cavalo e deu-lhe o soco na testa. O cavalo fugiu. Nesse momento os guardas chegaram, pegaram o bandoleiro e o levaram para a cadeia. (p. 123)

Era uma vez, um ferreiro. Certo dia, forjava ele uma ferradura e levantou o martelo com tanta força que o martelo se desprendeu do cabo, saiu voando pela janela, matou quatro pombos, acertou a torre de incêndio, desviou para o outro lado, quebrou a janela da casa do capitão do corpo de bombeiros, voou por cima da mesa, a qual estava sentado o próprio capitão com a mulher, rachou a parede na casa do capitão e saiu voando para a rua. Nisso, derrubou o poste de luz no 
chão, passou uma rasteira no sorveteiro e bateu na cabeça de Karl Ivánovitch Shusterling que, bem nessa hora, tinha tirado o chapéu para arejar a nuca. Depois de bater na cabeça de Karl Ivánovitch Shusterling, o martelo voou de volta e tornou a passar rasteira no sorveteiro, derrubou do telhado dois gatos que brigavam, virou uma vaca de ponta-cabeça, matou quatro pardais e entrou voando de novo na serralheria, caiu bem no cabo que o ferreiro ainda continuava a segurar com a mão direita. Tudo isso aconteceu tão rápido que o ferreiro não notou nada e continuava a forjar a ferradura. (p. 124)

Assim, na qualidade de um real escritor impedido de publicar, por questões políticas, Khams consegue encontra maneiras de extrapolar os limites da LIJ soviética, embutindo em seus trabalhos procedimentos que usaria na literatura para adultos, proibida pelo regime. 


\section{CONSIDERAÇÕES FINAIS}

Ao longo de nosso estudo, observamos a transformações ocorridas no cenário artístico soviético decorrentes da intervenção política do novo regime. A literatura passa a ser um dos principais meios de divulgação doutrinária e educação dos cidadãos por parte do Estado e a imposição da estética realista, consumada pelo Realismo Socialista, impunha uma brusca interrupção aos projetos de muitos escritores, entre eles o jovem poeta oberiúty Daniil Kharms.

Como consequência, as vanguardas ainda existentes são proibidas, assim como todo tipo de experimentalismo artístico tanto por parte de artistas individuais, quanto em grupo. Essas modificações foram executadas oficialmente sob a justificativa de que as massas necessitavam de obras capazes de veicular os valores da nova sociedade coletiva e proletária de forma clara, a partir da utilização de linguagem simples e métodos de representação mais palatáveis. Assim, a literatura soviética assume seu papel educativo junto aos cidadãos daquele país.

Nessa conjuntura, Kharms ingressa na literatura infantil afim de conseguir meios para a própria subsistência, mas também como subterfúgio para divulgar sua produção, independentemente do gênero utilizado. Por isso, sua obra dedicada à criança apresenta os mesmos procedimentos verificados em sua produção para o público adulto, à época proibida.

A prosa infantil kharmisiana dialoga com a tradição dos contos maravilhosos, sobretudo, quando toma-lhes emprestado seu linguajar, suas fórmulas prontas, seus seres fabulares e suas funções morfológicas. Contudo, essas marcas são empregadas para que o leitor tenha a impressão de estar diante de um gênero familiar. Por outro lado, a quebra com encantamento típico do gênero, a depreciação da figura do herói, o fim do final feliz 
e a aproximação com a realidade, entre tantos outros elementos aqui analisados, fazem com que os contos percam sua aparência infantil e adquiram uma linguagem mais uniforme, visando o leitor adulto.

Assim, as histórias de Kharms manifestam o nivelamento dos gêneros literários preconizado por uma sociedade que via pouca distinção na educação de crianças, jovens ou adultos, tendo em vista que, independentemente da idade, todos eles eram cidadãos e, portanto, construtores da futura pátria soviética.

A modernidade impressa aos contos infantis do escritor extrapola o âmbito literário e passa a abranger questões importantes para o universo soviético, a medida em que a obra torna-se eficaz tanto para as crianças, quanto para adultos. Nas primeiras, ela presta-se a cultivar valores referentes ao trabalho, ao estudo e ao esforço pessoal, aproximando suas expectativas da realidade e excluindo soluções mágicas. Ao passo que, os últimos encontram, na leitura, o reforço dessas mesmas convicções sociais.

Nesse sentido, a literatura infantil de Kharms revive a atmosfera ancestral dos contos populares, quando as histórias narradas pelos contadores eram partilhadas por toda a comunidade, dos mais jovens aos mais velhos, visto que os ensinamentos veiculados eram de serventia comum. Talvez seja essa característica que tenha tornado as histórias desse escritor tão modernas e, ao mesmo tempo, atrativas para um público leitor variado, até nossos dias.

A análise da obra infantil de Daniil Kharms, realizada nesta dissertação, pretendeu, assim, lançar luz sobre questões ainda não estudadas na obra do autor a partir de uma leitura possível de seu trabalho, sob a ótica da tradição e da modernidade. Esperamos ter contribuído para a divulgação de sua produção entre o público leitor brasileiro. 


\section{REFERÊNCIAS BIBLIOGRÁFICAS:}

\section{Obras de consulta:}

LO GATTO, E. La literatura rusa moderna. Buenos Aires: Editorial Losada, 1972.

MOSER, C. A. Cambridge history of Russian literature. Cambridge University Press, 1999.

NIKOLAIEV, P. A. (org.) Russkie pissáteli 20 veka: biografitcheski slovar. Moskva: Bolshaia Rossískaia Entsiklopédia, 2000.

TERRAS, V. (org.) Handbook of Russian Literature. New Haven, Yale University Press, 1985.

\section{Obras de Kharms:}

KHARMS, D. Vek Daniila Kharmisa. (Org.) Trofimova, I. Moskva: Zebra, 2009.

KHARMS, D. Sobranii sotchinenii v triox tomakh. (Org.) V. Sajin. Sankt-Peterburg: Azbuca, 2011.

KHARMS, D. Daniil Kharms v dvukh tomakh. Moskva: Viktoria, 1994.

KHARMS, D. “A velha”. Trad. Sheila Oliveira Lima. In: LIMA, S. O. "A velha” uma representação intertextual do absurdo. Dissertação de mestrado. São Paulo: FFLCH USP, 2001.

KHARMS, D. “O baú”. Trad. Boris Schnaiderman. In: Revista USP, n. 10, 1991.

KHARMS, D. et alii. "Manifesto Oberiu". In: KHARMS, D. Os sonhos teus vão acabar contigo: prosa, poesia, teatro. São Paulo: Kalinka, 2013.

\section{Obras sobre Kharms:}


GIBIAN, G. Russia's lost literature of the absurd. New York: The Norton Library, 1974.

GLOTSER, V. Marina Málitch. Moi muj Daniil Kharms. Moskva: B. S. G. - Press, 2000.

KARPOV, V. A. Daniil Kharms kak diétskii pisátel. Revista: Natchálnaia schkóla plius do $i$ pósle, 2010, n. $6, \quad$ p. 62 - 66. Disponível em: <http://www.dharms.ru/library/daniil-harms-kak-detskiy-pisatel.html $>$ Acesso em Nov/ 2014.

KOBRINSKI, A. Daniil Kharms. Moscou: Molodaia Gvardia, 2009.

LIMA, S. O. “A velha” uma representação intertextual do absurdo. Dissertação de mestrado. São Paulo: FFLCH - USP, 2001.

TUMANOV, V.; TUMANOV, L. "The child and the child-like in Daniil Charms." In: Russian Literature. Western University. N. 34, 1993, p. 241 - 269. Disponível em: <http://www.sciencedirect.com/science/journal/03043479/34/2> Acesso em Out/ 2014.

\section{Obras gerais:}

AMÉRICO, E. V. Piotr Bogatyriov e os estudos de folclore na Rússia. Dissertação de Mestrado. FFLCH - USP, 2006.

AFANAS'EV, A. (org.) Contos de fadas russos. São Paulo: Landy editora, 2003.

ANDRADE, H. F. “O realismo socialista e suas (in) definições.” In: Literatura e Sociedade. N. 13, São Paulo: 2010. 
ANDRADE, H. F. (org.) Caderno de literatura e cultura russa. São Paulo: Ateliê Editorial, 2004.

ANDRADE, H. F. Materiais para um estudo do cubo-futurismo. Dissertação de Mestrado. FFLCH -USP, 1985.

AZENHA JR., J. "Dependências, assimetrias e desafios na tradução para crianças e o jovem no Brasil.” In: RAMOS, E.; SCHEYERL, D. (org.) Vozes. Olhares. Silêncio: diálogos transdisciplinares entre linguística aplicada e a tradução. Salvador: EDUFBA, 2008.

BAKHTIN, M. Problemas da poética de Dostoievski. Trad. Paulo Bezerra. Rio de Janeiro, Forense-Universitária, 1981.

BAKHTIN, M. A cultura popular na Idade Média e no Renascimento: o contexto de François Rabelai. Trad. Yara F. Vieira, São Paulo: Hucitec, 2010..

BALINA, M. "Creativity through restraint: the beginnings of Soviet children's literature." In: Routledge Russian Children's Literature and Culture. New York/ London: Toutledge, 2010.

BENJAMIN, W. “O narrador. Considerações sobre a obra de Nikolai Leskov.” In: Obras escolhidas: magia e técnica, arte e política. Vol. 1. São Paulo: Brasiliense, 1996.

BENJAMIN, W. "A tarefa do tradutor." In: Escritos sobre mito e linguagem. São Paulo: Editora 34, 2011.

BERMAN, M. Tudo o que é sólido desmancha no ar. Trad. Carlos F. Moisés e Ana Maria L. Ioriatti. São Paulo: Companhia de Bolso, 2014. 
BETTELHEIM, B. A psicanálise dos contos de fadas. Trad. Arlene Caetano. São Paulo: Paz e terra, 2002.

BOLLE, W. "Viagem a Moscou: o mito da revolução". Revista USP, n. 5, marmai./1990, p. 117- 34.

BONNEMASOU, V. “A integração das artes e a pós-modernidade”. In: Revista Significação, V. 29, N. 18, 2002, p. 115 - 124.

BURGER, P. “O declínio da era moderna”. Trad. Heloisa Jahn. In: Novos estudos CEBRAP, n. 20, São Paulo: Março, 1988, p. 81 - 95.

BURGER, P. Teoria da vanguarda. Trad. José Pedro Antunes. São Paulo: Cosac Naify, 2012.

CADEMARTORI, L. $O$ que é literatura infantil. São Paulo: Editora Brasiliense, 2010.

CAPRILES, R. Makarenko: o nascimento da pedagogia socialista. São Paulo: Editora Scipione, 1989.

CAVAlIERE, A. O inspetor geral de Gógol/ Meyerhold. São Paulo: Perspectiva, 1996.

COELHO, N. N. Panorama histórico da literatura infanto-juvenil. São Paulo: Ática, 1991.

COELHO, N. N. Literatura infantil: teoria, análise, didática. São Paulo: Moderna, 2000.

COELHO, N. N. O conto de fadas: símbolos, mitos, arquétipos. São Paulo: Difusão Cultural do Livro, 2003. 
DARNTON, R. O grande massacre de gatos e outros episódios da história cultural francesa. Trad. Sônia Coutinho. Rio de Janeiro: Graal, 1988.

DOBRENKO, E. "The school tale in children's literature of socialist realism." In: Routledge Russian Children's Literature and Culture. New York/ London: Toutledge, 2010.

FIGES, O. The Whisperers: Private Life in Stalin's Russia. New York: Metropolitan Books, 2007 (Livro eletrônico).

FRANK, J. Pelo prisma russo. Trad. Paula Cox Rolim e Francisco Achcar. São Paulo: Edusp, 1992.

GOTLIB, N. B. Teoria do conto. São Paulo: Ática, 2003.

HOBSBAWN, E.; RANGER, T. A invenção das tradições. Trad. Celina Cardim Cavalcante. São Paulo: Paz e Terra, 2008.

JOLLES, A. Formas simples. Trad. Álvaro Cabral. São Paulo, Cultrix, 1976.

LUKACS, G. "Narrar ou descrever.” In: Ensaios sobre literatura. Rio de Janeiro: Editora Civilização Brasileira, 1965.

MAIAKÓVSKI, V. Poemas. Trad. Augusto e Haroldo de Campos e Boris Schniderman. São Paulo: Perspectiva, 1997.

MAGALHÃES JR. R. A arte do conto. Rio de Janeiro, Bloch,1972.

MELETÍNSKI, E. M. Os arquétipos literários. Trad. Aurora Fornoni Bernardini, Arlete Cavalieri e Homero Freitas Andrade. São Paulo: Ateliê Editorial, 2002.

MORAES, A. D. Reflexos da violência na literatura infanto-juvenil. São Paulo: Letras \& Letras, 1991. 
NIKOLAEV, P. A. (org.) Ruskie pissateli 20 veka. Moskva: Randevu-am, 2000.

OLIVEIRA, C.M., et. ali. "O prelúdio da educação russa no período prérevolucionário a 1917” In: Revista Eletrônica Arma da Crítica. N. 2, Dez. 2010, p. 240 - 252. Disponível em: <http://www.armadacritica.ufc.br> Acesso em Jan./2015.

POMORSKA, K. Formalismo e futurismo. São Paulo: Ed. Perspectiva, 1972.

PONTIERI, R. L. "Formas históricas do conto: Poe e Tchekhov.” IN: BOSI, V. et al. (orgs.) Ficções: leitores e leituras. São Paulo, Ateliê, 2001.

PROPP, V. Morfologia do conto maravilhoso. Rio de Janeiro: Forense Universitária, 1984.

RIPELLINO, A. M. Maiakóvski e o teatro de vanguarda. Trad. Sebastião Uchoa. São Paulo: Perspectiva, 1971.

RIPELLINO, A. M. O truque e a Alma. Trad. Roberta Barni. São Paulo: Perspectiva, 1996.

SCHARF, A. "Suprematismo.” In: STANGOS, N. (org.) Conceitos da arte moderna. Trad. Álvaro Cabral. Rio de Janeiro, Jorge Zahar Editor, 1991.

SLONIM, M. Escritores y problemas de La literatura sovietica 1917 - 1967. Madri: Alianza Editorial, 1974.

SOSA, Jesualdo. A literatura infantil. Trad. James Amado. São Paulo: Cultrix, 1978.

TCHEKHOV, A. "A dama do cachorrinho" e outros contos. trad. Bóris Schnaiderman. São Paulo, Max Limonad, 1986.

THOMAZ, N. X. Alice em metamorfose: o grotesco e o nonsense em diálogo nas obras de Carroll e Svankmajer. Dissertação de Mestrado. FFLCH-USP, 2012. 
THOMSON-WOHLGEMUTH, G. "Flying high: translation of children's literature in East Germany”. In: VAN COILLIE, J.; VERSCHUEREN, W. Children's literature in translation. Challenges and Strategies. Manchester \& Kinderhook: Sr. Jerome, p. 47- 59.

TIPPNER, A. "Evgenii Shvarts's fairy tales dramas: theater, power and the naked truth." In: Routledge Russian Children's Literature and Culture. New York/ London: Toutledge, 2010.

TODOROV, T. Introdução à literatura fantástica. São Paulo: Editora Perspectiva, 2003.

TODOROV, T. As estruturas narrativas. São Paulo: Perspectiva, 2011.

TROTSKY, L. Literatura e revolução. Rio de Janeiro: Zahar, 1969.

TUMANOV, L. et alii "The child and the child-like in Daniil Charms". NorthHolland: Elsevier Science Publisher, 1993, p. 1 - 30.

VOLKOV, S. São Petersburgo: uma história cultural. Trad. Marcos Aarão Reis. Rio de Janeiro - São Paulo: Editora Record, 1997.

ZILBERMAN, R. "Transitoriedade do leitor e do gênero" In: A literatura infantil na escola. Rio de Janeiro: Editora Global, 1985, p. 43 - 61. 